\title{
Diversity of tropical macroalgae in the New Zealand marine aquarium trade
}

\author{
By \\ Kirill Oliver William Woodhouse
}

A thesis submitted to the Victoria University of Wellington in partial fulfilment of the requirements for the degree of

\author{
Master of Science \\ In Marine Biology
}

Victoria University of Wellington, New Zealand 2019
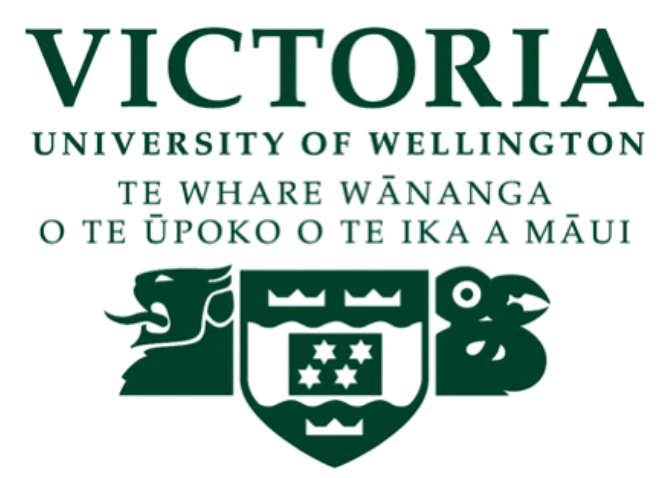


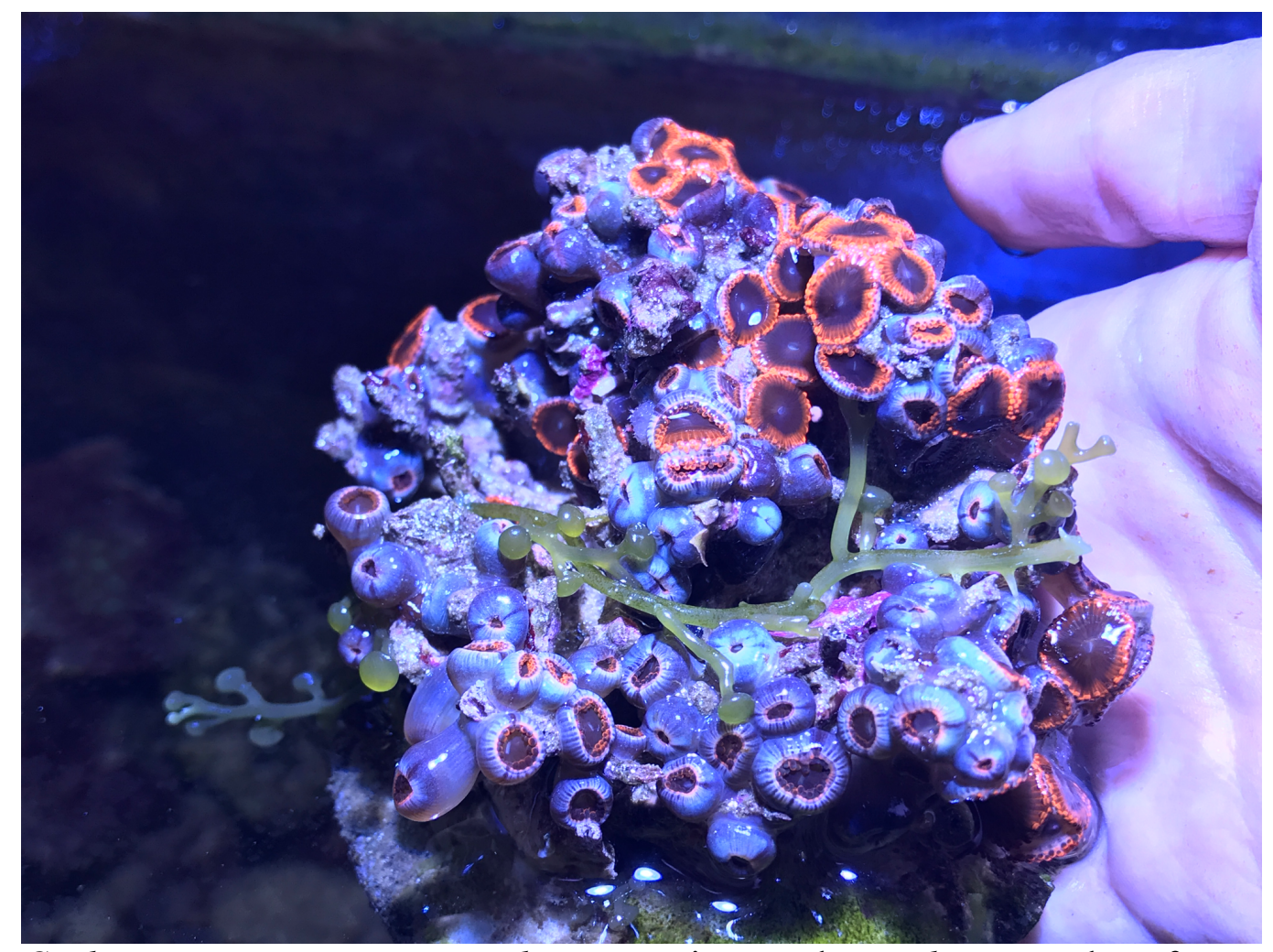

Caulerpa racemosa var. macrophysa on an imported Zoanthus sp., colony from one of my coral holding tanks 


\section{Abstract}

Exotic species often slip through international borders undetected. Many perish but for some species introduction to a foreign land or sea brings release from natural enemies and a chance to establish a population. Increased global trade has increased the frequency of species introductions through stowaways and lapses in biosecurity. Once an invader is established there is the opportunity for explosive population growth at the detriment of native species and humans. The marine aquarium trade is a significant vector of species introductions, including algal introductions. The most publicized introduction from aquaria was the release of the green alga Caulerpa taxifolia from the Oceanographic Museum in Monaco. C. taxifolia introduction had large negative impacts on the invaded ecosystem.

Molecular barcoding of tropical macroalgae entering the New Zealand aquarium trade was implemented using various molecular markers (cox1, cox3, rbcL tufA, LSU). Both NCBI Blast searches and maximum-likelihood phylogenies were used to identify the isolates. A total of 62 species of tropical macroalgae were identified from coral rocks imported into New Zealand, plus samples from reef hobbyists. Some species found are known as invasive elsewhere, for example, Caulerpa cylindracea, C. racemosa, $C$. sertularioides, Ulva ohnoi and Chaetomorpha vieillardii. All three major groups of algae were well represented in my findings with 26 species of red algae, 24 species of green algae and 12 species of brown algae. Temperature tolerance limits are the largest determinant in survival in algae, while salinity and $\mathrm{pH}$ are less significant. Temperature tolerance of tropical algae to the minimum Sea Surface Temperature in Auckland $\left(14^{\circ} \mathrm{C}\right)$ and Wellington $\left(11^{\circ} \mathrm{C}\right)$ was tested. My results show that one species Chaetomorpha vieillardii can survive at Auckland minimum winter sea surface temperatures. Our findings have important implications for New Zealand biosecurity, as not only are a large 
diversity of exotic macroalgae entering the New Zealand marine aquarium trade unregulated, but there is also the potential for them to survive in New Zealand waters. 


\section{Acknowledgements}

I wish to thank my thesis advisor Associate Professor Joe Zuccarello for his advice and continuous encouragement throughout my two years of study. I am particularly grateful for his guidance, direction and insightful critique during my research and writing of this thesis.

I would also like to acknowledge two fellow Victoria University post graduates: Sergio Diaz for his contribution to laboratory morphological identification and Maren Preuss for her assistance in the delivery of herbarium specimens to TePapa Museum. 


\section{Table of contents}

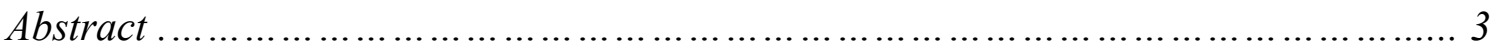

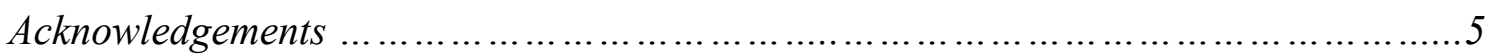

\subsection{Introduction}

1.1 Species Introductions and ecological hypothesis on the effects of invasions ........8

1.2 Marine introduction ............................................................. 11

1.3 Aquarium trade mediated introductions ......................................... 13

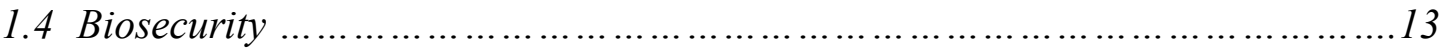

1.5 Algal introduction ............................................................... 14

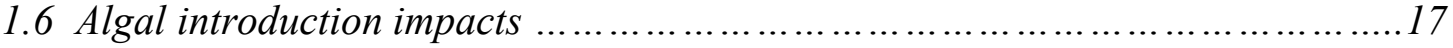

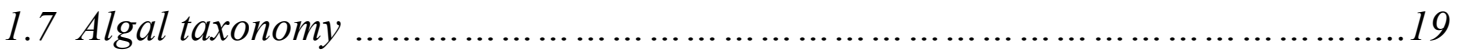

1.8 Molecular identification and barcoding .........................................20

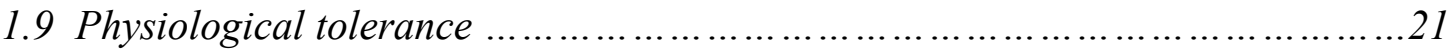

\subsection{Materials and Methods}

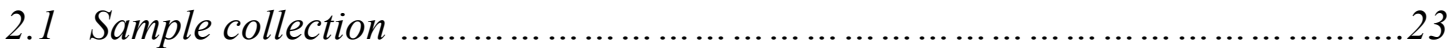

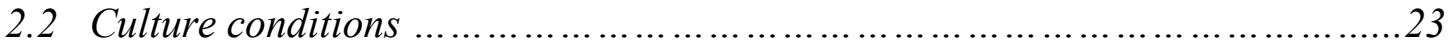

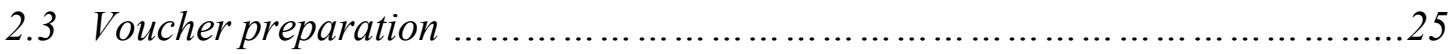

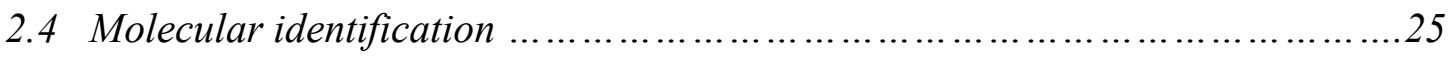

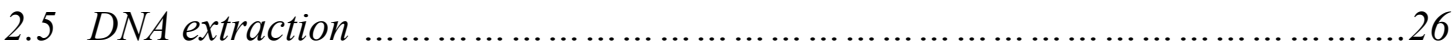

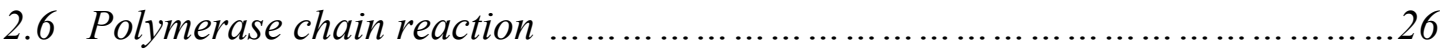

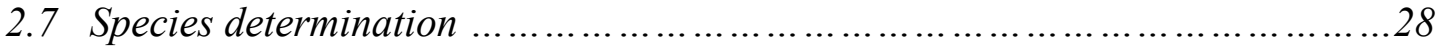

\subsection{Results}

3.1 Identification of red algae ................................................... 30

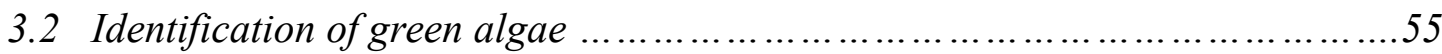

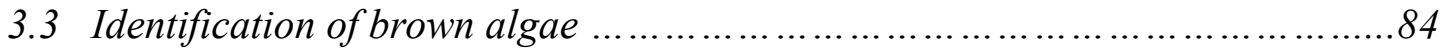




\subsection{Discussion}

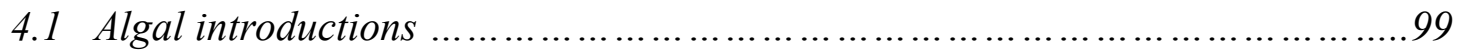

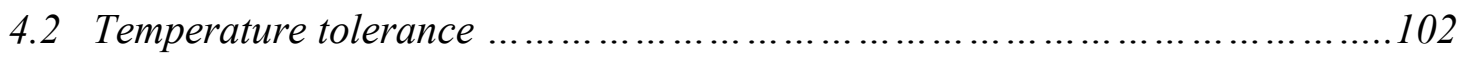

4.3 Implications of propagule pressure on algal introductions ......................103

4.4 Algal reproduction in aquaria ................................................... 104

4.5 Polymorphic species ...................................................... 104

4.6 Cryptic diversity ......................................................... 105

4.7 Utility of BLAST and Maximum-Likelihood Phylogenies in molecular

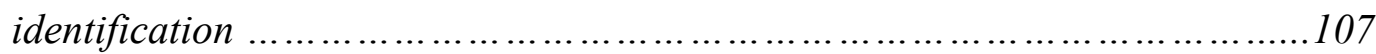

4.8 Limitations of public database sequences ........................................ 108

4.9 Regulation and prevention of algal introductions from aquaria ...............110

\subsection{Limitations and future research}

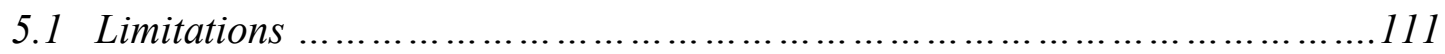

5.2 Future research ............................................................ 112

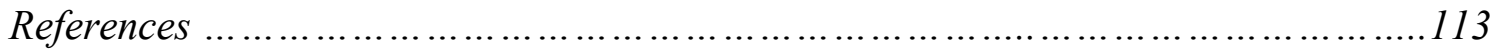

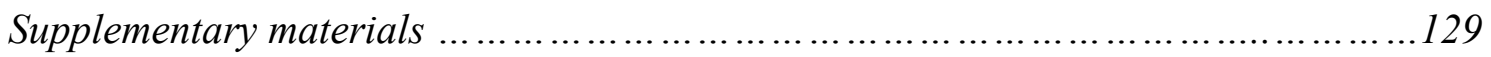




\section{Introduction}

\subsection{Species introductions and ecological hypothesis on the effects of invasions}

Species introductions can have a detrimental effect on the environment (Gozlan et. al. 2009). Humans facilitate many species introductions through their movement (anthropogenic introductions) (Heike et. al. 2014). Species introductions can be considered a more significant environmental stressor than eutrophication and toxic chemical release (Chapman 1995). Introducing non-native freshwater fish to new habitats has a variety of detrimental impacts on the environment, including increased predation. For example, predation from the introduced fish Salmo trutta (Linnaeus 1758) and Oncorhychus mykiss (Walbaum 1792) reduce recruitment of juvenile Galaxias vulgaris (Stokell 1949) in New Zealand rivers (Woodford and McIntosh 2010), leading to habitat degradation and increased competition for resources with native biota. The largest predictor variable of native fish decline in Iberian streams was invasive fish introduction (Hermoso et. al. 2011). Hybridization of introduced species with closely related native species may occur post-introduction. For example, Nile Tilapia hybridized with native Oreochromis (Günther 1889) in Zambia (Deines et. al. 2014). Another threat from species introduction is disease transmission. For example, the intracellular fish parasite Sphaerothecum destruens was introduced to Europe from China carried by Pseudorasbora parva (Temminick and Schlegel 1846), the introduction was followed by mortality in a large range of native host fish (Andreou et. al. 2012). These introductions may even prevent proper ecosystem function (Gozlan et. al. 2009). Terrestrial systems also suffer from species introductions. For example, the Argentine ant, Linepithema humile (Mayr 1868), is a well-documented introduced species to many countries and has displaced native ants and altered invertebrate community structure (Wild 2004). 
An introduced species is one transported to a non-native habitat by natural pathways, humans or human activity (anthropogenic introductions) (Alpert 2006). The absence of population regulatory forces can lead to exponential population growth of introduced species to the detriment of native flora and fauna, making an introduced species an invasive species (Briggs 2012). There are differing views on the definition of invasive species. One view is that an invasive species is "any introduced non-native that causes harm to the economy, environment or human health post-introduction" (U.S. Executive Order 13112 1999). Another view is that the invader does not need to cause harm but population size and spread beyond the location of introduction is a criterion for being invasive (Moutou and Pastoret 2010). An introduced species that remains at low population density with little to no detriment to the ecosystem remains simply an introduced species (Moutou and Pastoret 2010).

There have been many hypotheses on factors that facilitate invasion of an introduced species. Prominent are: a) enemy release; b) propagule pressure; c) competitive exclusion; and d) disturbance. The enemy release hypothesis states that introduction of a foreign species to a habitat may release it from the predation and competition pressures present in its native range (Liu and Stiling 2006). For example, enemy release has been proposed for the spread of Acer platanoides (L.) "Norway maple" introduced across North America. Norway maple had three times lower rates of herbivory in its introduced range versus its native range in Europe. Norway maple also had lower fungal damage in its introduced range (Adams et. al. 2009). Another example of enemy release is the lower occurrence of herbivore damage in North American introduced populations than European populations of Klamath weed, Hypericum perforatum (L.) (Vila et. al. 2005). 
The propagule pressure hypothesis for facilitation of invasion success explains why some species do not successfully establish post-introduction even though the habitat is suitable (Eschtruth and Battles 2011). Propagule pressure is frequently used to explain the variation in invasion success in plant communities (Richardson and Pyšek 2006). The more seeds (larger propagule amounts) introduced to the non-native habitat, the more likely the species can establish. There is often interaction between propagule pressure and disturbance in predicting introduction success. For example, experimental increases in propagule numbers and disturbance of habitat in the brown alga Sargassum muticum (Yendo) Fensholt increased recruitment success (Britton-Simmons and Abbott 2008) in Washington, USA.

Competitive exclusion may occur when introduced species displace native species (Bøhn et. al. 2008). The introduced mud snail Ilyanassa obsoleta (Say 1822) feeds on the eggs of the native mud snail Cerithidea californica (Haldeman 1840) and competitively excludes it from tidal creeks in San Francisco (Race 1982). Competitive exclusion does not always occur with introductions. For example, in the St Francis River crayfish, Orconectes quadruncus (Creaser 1933), habitat use did not alter when sympatric with the invasive woodland crayfish Orconectes hylas (Faxton 1890) (Westhoff and Rabeni 2013). The impact of an invasive species' introduction on an ecosystem is dependent on present species interactions. For example, if an invader displaces an important habitat species but doesn't fulfill the same ecosystem services then the overall ecological impacts may be severe. On the other hand, if an invasive species fills the ecological role of the displaced species then the impacts are less severe (Rodriguez 2006). For example, the introduced Woodland crayfish displaces the St Francis river crayfish but has the same role as the St Francis river crayfish being an omnivorous 
scavenger of fallen plant materials and insects and is prey for fish and birds (Westhoff and Rabeni 2013).

Disturbance events or environmental change can and will increase the risk of species invasion (Stachowicz et. al. 2002). If a habitat is available and if it is not promptly filled by a native species then there is the chance that an introduced species will colonize that habitat. In the Chilean Andes, disturbance was the largest determinant of plant invasion success regardless of elevation or temperature (Lenbrechts et. al. 2016). $40-56 \%$ of the variation in the study's model for plant invasion success was explained by disturbance, while propagule pressure only explained $10 \%$ of the variation.

Increasing global sea surface temperature increases risk of invasion of nonindigenous marine species from warmer climates (Stachowicz et. al. 2002). Global warming causes species range shifts latitudinally and may facilitate invasion, for example, as tropical species range further pole wards (Stohlgren et. al. 2005; OcchipintiAmbrogi 2007). The largest threat to biotic communities may not be from increasing annual mean temperature but the maximum and minimum temperatures giving invaders a head start over native species (Stachowicz et. al. 2002). Global warming may also facilitate a dominance shift of non-native species leading to global biotic homoginisation (Stachowicz et. al. 2002).

\subsection{Marine introduction}

Increased international shipping brings higher risk of transporting marine species between continents. Ballast water frequently supports live organisms from various taxa including planktonic stages (Hyun et. al. 2017). Whole coastal planktonic assemblages can be transported across oceanic barriers to similar habitats (Geller and Carlton 1993). Homogenization of coastal communities may occur through the hybridization of closely 
related native and introduced fauna (Carlton 1979). Bays and estuaries used as ports are especially vulnerable ecosystems (Geller and Carlton 1993).

Hull fouling is estimated to have introduced $74 \%$ of the nonindigenous marine invertebrates to the Hawaiian Islands (Eldredge and Carlton, 2002) and 42\% of the 26 unintentionally introduced marine species to Japan (Otani 2006). Unintentional introductions mediated by aquaculture occur through fouling aquaculture equipment, cages, lines and floats provide surfaces for recruitment and can be used as steppingstones for invasive species (Campbell et. al. 1017; Kim 2007).

Aquaculture mediated species introductions often occur from intentional release of aquaculture species for future harvest. For example, Chinook salmon to New Zealand (McDowall 1994; Quinn et. al. 1996), Tilapia cichlids Oreochromis spp. introduced to Asia (Gozlan et. al. 2009) and shellfish culture (Ruiz et. al. 1999). These non-native species introduced for commercial purposes, often have dire consequences for native biodiversity (De Leaniz et. al. 2010). Salmonoid introduction to the southern hemisphere was an attempt by governments and fisheries to capitalize on what they felt was an underutilized niche as the majority of native freshwater fish were small and not of interest by sports fishermen (De Leaniz et. al. 2010). Salmonoids are currently one of the largest threats to native Galaxids in New Zealand (De Leaniz et. al. 2010). Fisheries mediated introduction of coarse fish to New Zealand for recreational purposes; for example, Rudd (Scardinius erythrophthalmus (Linnaeus 1758)), Perch (Perca fluviatilis (Linnaeus 1758)) and Tench (Tinca tinca (Linnaeus 1758)) has played a part in the decrease in lake water clarity and quality (Rowe 2007). Perch are also suspected in the increased frequency of cyanobacterial blooms in the Karori Reservoir in Wellington due to top down control on zooplankton, the primary prey of juvenile perch (Smith and Lester 
2007). Introduced fish are also predators on native fish and have also threatened breeding grounds (Rowe 2007).

\subsection{Aquarium trade mediated introductions}

The aquarium trade is a significant vector of species introductions (Gertzen et. al. 2008; Semmens et. al. 2004). However, the trade has received little attention and risks have not been well studied (Calado and Chapman 2006). One third of aquatic invasive species that have had large detrimental impact to native biodiversity are either ornamental or aquarium species (Padilla and Williams 2004a; 2004b). For example, Koi carp (Cyprinus carpio) (Linnaeus 1758); goldfish (Carassius auratus) (Linnaeus 1758); and plants such as Elodea canadensis (Michx); Egeria densa (Planch); Lagarisiphon major (Ridl) and Ceratophylum dermesum (L.) (oxygen weeds) have been introduced to New Zealand waterways as aquarium or pond discards (Chapman 1996).

\subsection{Biosecurity}

The Ministry of Primary Industries (MPI) takes biosecurity threats seriously as there are large implications for New Zealand biodiversity and economic production if a species capable of disrupting the ecosystem, or interfering with economically important species becomes established (MAF Biosecurity New Zealand 2009a; 2009b). There are also large economic costs in loss of production and for pest eradication or control postinvasion (Goldson et. al. 2015). Online trading of flora and fauna has long been a risk to New Zealand's native biota as introductions are inevitable (Derraik and Phillips 2010).

Biosecurity risk assessment for the importation of live fish, invertebrates and aquarium plants to New Zealand is primarily based around introduction of pathogenic microbes. For example, the bacteria Aremonas salmonicida, Flavobacterium 
psychrophilium or viruses: Cyprinid herpesvirus-3, Macrobrachium rosenbergii nodavirus (MrNV) are considered risk species (MAF Biosecurity New Zealand 2009a; 2009b). Dried, preserved and live plants and algae can be imported for research purposes (MAF Biosecurity New Zealand 2010). Live specimens imported for research use are to be maintained in containment facilities.

In New Zealand, livestock importers are allowed to import corals, invertebrates, fish and aquarium plants from all countries under strict protocols set out by MPI to reduce risk of introducing foreign diseases (MAF Biosecurity New Zealand 2009a; 2009b). On importation Convention of International Trade in Endangered Species (CITES) permits need to be provided for listed species of corals and other invertebrates along with environmental protection authority (EPA) permits (MAF Biosecurity New Zealand 2009a; 2009b). Tests for viruses must be done before livestock is released for sale and all mortalities reported to MPI. If $20 \%$ mortality occurs during quarantine then laboratory testing for pathogens needs to be carried out (MAF Biosecurity New Zealand 2009a; 2009b). Corals, bivalves and the rocks that they are attached to harbor algal spores and juveniles; many too small or slow growing to be visualized during the 4-6 week quarantine period. Many algae survive and grow once sold to hobbyists or pet shops (personal observations).

\subsection{Algal introduction}

Macroalgae are frequently introduced world-wide both intentionally for commercial purposes and unintentionally. Vectors of unintentional introduction include ballast water release (Carlton and Galler 1993), hull fouling (Mineur et. al. 2007), plus aquaculture equipment fouling, for example, equipment fouled by the brown alga 
Undaria pinnatifida (Harvey) Suringar (James and Shears 2016), and the green alga Codium fragile var. tomentisoides (Van Goor) P.C.Silva (Dromgoole 1975). U. pinnatifida was also transported between mussel farms in New Zealand on equipment (Forrest and Blakemore 2006). Intentional introductions mostly occur from algal mariculture. Algal mariculture is an important industry in developing nations for food production and export (Halling et. al. 2013; Pickering et. al. 2007). Potential candidates for mariculture are often introduced to new locations when algae of high suitability for aquaculture are lacking (Halling et. al. 2013; Pickering et. al. 2007). A review in 2007 found that 277 species of algae are introduced and some algal families contain many more successful invaders than others. For example, the green algal families Caulerpaceae and Codiaceae, the brown algae of the Fucaceae and Alariaceae, and the red algal families Ceramiaceae and Rhodomelaceae are particularly prevalent (Williams and Smith 2007).

The red alga Acanthophora spicifera (M.Vahl) Børgesen introduced to Pearl Harbor, Hawaii in 1952 invaded habitat previously dominated by Laurencia nidfica J.Agardh and outcompetes many species, including Hypnea cevricornis (J.Agardh) E.Y.Dawson. Hypnea musciformis (Wulfen) J.V.Lamouroux was introduced to Hawaii from Florida in 1974 for production of carrageenan. It has since partially displaced the native Hypnea cervicornis (Russel 1992). The introduced Gracilaria salicornia (C.Agardh) E.Y.Dawson had a range expansion of 280 meters per year in Hawaii (Cox 1999). Kappaphycus alvarezii (Doty) Doty ex P.C.Silva and Kappaphycus striatum (F. Schmitz) P.C.Silva are also introduced species in Hawaii that have spread on average 250 meters per year since their introduction to Kane'ohe Bay, O'ahu (Cox 1999; Conkin and Smith 2005). 
Undaria pinnatifida (Laminariales) is native to Japan, Korea and China and was found in Wellington Harbor, New Zealand in the 1980's (Hay and Luckens 1987). U. pinnatifida has been introduced to Baja California (Aguilar-Rosas 2013), Argentina (Meretta et. al. 2012), France for aquaculture (Castric-Fey et. al. 1993; James et. al. 2016), Spain (Peteiro et. al. 2016), and Australia (Campbell and Burrage 1998; Sanderson 1990).

Green algae species from the genus Caulerpa have been introduced to various locales outside their native range. C. taxifolia (M.Vahl) C.Agardh and C. racemosa (Forsskål) J.Agardh have been introduced to the Mediterranean Sea (Piazzi and Ceccherelli 2002; Piazzi et. al. 2003). C. brachypus f. parvifolia (Harvey) A.B.Cribb is a recent introduction to Florida (Lapointe and Bedford 2010).

Some algal introductions can be directly attributed to the aquarium trade. The most publicized introduction is Caulerpa taxifolia released from the Oceanographic Museum, Monaco (Baulch 1999; Meinesz and Hesse 1991). It is common practice to maintain macroalgae in sumps or refugia as a method of trapping nutrients from aquaria. As the alga grows it is fragmented and sections are discarded to remove the nutrients from the aquarium. Species kept include Caulerpa racemosa (Forsskål) J.Agardh, Caulerpa serrulata (Forsskål) J.Agardh and C. taxifolia (Zaleski and Murray 2006). The filamentous green alga Chaetomorpha sp. previously thought to be a safe alternative to Caulerpa for growing in aquaria may be of high introduction risk due to its wide range of temperature tolerance, fast growth and ease of fragmentation (Odom 2014).

Chaetomorpha vieillardii (Kützing) M.J.Wynne has invasive potential as shown in Guam (University of Guam https://cnas-re.uog.edu/wpcontent/uploads/2018/09/IInvasive_speciesGuam.pdf). 


\subsection{Algal introduction impacts}

Algal introductions, if successful, may have negative consequences for the native biotic community. Impacts of an invasive algal introduction include decreased abundance and species richness in native seaweeds (Levin et. al. 2002). Green algae from the order Caulerpales are well known for their invasive nature in the Mediterranean and Australia (Wiedenmann et. al. 2001; Piazzi and Ceccherelli 2002; Piazzi et. al. 2003). There are numerous impacts of Caulerpa sp. on native communities from shading (Meinesz et. al. 2001). Mediterranean introduced genotypes of Caulerpa taxifolia and Caulerpa cylindracea Sonder are strong competitors of native seaweeds (Piazzi et. al. 2003; Piazzi et. al. 2016) and sea grasses (Ceccherelli and Cinelli 1997; Ceccherelli et. al. 2002). C. taxifolia can have effects on seagrasses, for example, Posidonia oceanica (L.) Delite has decreased leaf size and increased terpenoid concentrations when in competition with $C$. taxifolia. Caulerpa taxifolia, on the other hand, increases its frond size when competing with the seagrass $P$. oceanica (Pergent-Martini et. al. 2008). Caulerpa taxifolia shows a change in morphology from thick to thin stolons and rachis, and an increase in fragmentation in invasive populations when introduced to non-native locations (Glasby 2013; Wright 2005). Fragmentation assists asexual reproduction in Caulerpa species and subsequent range expansion (Wright 2005). The green alga C. taxifolia also influences the substrate chemistry impacting biodiversity. C. taxifolia fragments had C:N ratio between 14-7 (Taylor et. al. 2010). This variation in C:N, compared to the C:N ratios for the following native detritus producers Avicennia marina (Forsskål) Vierh C:N ratio: 26.3 \pm 0.1 ; Posidonia australis Hook.F: $23.0 \pm 0.1$; Zostera capricorni Asch: $22.8 \pm 0.3$ (Taylor et. al. 2010), and the toxins associated with C. taxifolia detritus, had negative impacts on substrate micro-invertebrates (Ceccherelli and Cinelli 1997; Taylor et. al. 
2010). The decline in seagrass meadows the world over increases the threat that invasive algal introduction have on remaining seagrasses (Orth et. al. 2006).

Impacts of Caulerpa taxifolia introduction on seagrass are not always detrimental. For example, the Australian seagrass Posidonia australis J.D.Hooker was unaffected by C. taxifolia introduction, showing that the impacts of C. taxifolia invasion on seagrasses may be dependent on seagrass species or other variables (Glasby 2013). The shading of Caulerpa cylindracea by the canopy of Posidonia oceanica prevents successful invasion of established P. oceanica beds (Ceccherelli and Cinelli 1999; Bernardeau-Esteller 2015). Herbivores often show preference to native alga over introduced species. Fucus vesiculosus (L.) is preferred to Sargassum muticum (Yendo) Fensholt by the snail Littorina littorea (Linnaeus 1758) and the urchin Psammechinus miliaris (P.L.S. Müller 1771) in the North Sea (Schwartz et. al. 2016a; 2016b), while in some introductions herbivores prefer the introduced to native species (Vermeji et. al. 2009). Native herbivores may or may not be affected by anti-herbivory toxins in the non-native species. The Mediterranean urchin Paracentrotus lividus showed significant loss of spines and longer righting times when fed C. taxifolia exclusively compared to control algae (Boudouresque et. al. 1996). This may be due to the cocktail of toxins used to deter herbivory by many Caulerpa species (Erickson et. al. 2006). In southeastern Australia a variety of grazers, both fish and invertebrates, had preference to Sargassum sp. and Ulva sp. over the Caulerpa species: C. scalpelliiformis (R.Brown ex Turner) C.Agardh, $C$. filiformis (Suhr) Hering and C. taxifolia (Davis et. al. 2005).

The red alga Kappaphycus sp. overgrows live corals killing them. It frequently reaches biomasses over $10 \mathrm{~kg} / \mathrm{m}^{2}$ comprising up to $50 \%$ percentage cover on reefs (Conkin and Smith 2005). Kappaphycus sp. outcompetes native algae, can regenerate from small fragments and is of little interest to native herbivores. 
In South Australia, the introduced brown alga Undaria pinnatifida often establishes when canopies of native Phyllospora sp. are disturbed (Valentine and Johnson 2004). In France, Undaria pinnatifida show preference to artificial substrates free of other benthic organisms rather than rocky substrate, this may be due to it being less competitive than native kelps (Floc'h and Jean-Yves 1996). Most studies show $U$. pinnatifida as having little to no negative impact on native biodiversity (Floc'h and JeanYves 1996; Valentine and Johnson 2004). U. pinnatifida occurrence however reduced native species richness in Nuevo Gulf in Patagonia Argentina (Casas et. al. 2004). This is evidence that although $U$. pinnatifida was introduced to many locations including France, Australia and New Zealand and has established it is often simply an introduced species rather than becoming invasive.

\subsection{Algal taxonomy}

Algal taxonomy is an important discipline within phycology. Taxonomic knowledge is required for research in ecology, physiology, bio-assessment and algal genetics (Manoylov 2014). Taxonomic identification is regarded as the most common hypothesis testing practice in science (Manoylov 2014). The study of morphological characteristics of species is important for determining phylogenic relationships between taxa. Marine macroalgae are diverse organisms and are in three major groups; green algae (Chlorophyta), Red algae (Rhodophyta), and Brown algae (Ochrophyta, class Phaeophyceae). Red and green algae have primary plastids and the brown algae have secondary plastids derived from a red alga (Larkum and Vest 2003).

Many algae species are polymorphic (Verbruggen et. al. 2014) making it difficult to morphologically identify to species level with any accuracy. For example, the brown 
algal genus Sargassum has many polymorphic species (Mattio and Payri 2011). The Caulerpa racemosa-Caulerpa peltata species complex (Sauvage et. al. 2013) has morphologies ranging from umbrella-shaped branch tips to rounded tips plus intermediate morphologies making morphological identification difficult (Verbruggen et. al. 2014).

Algal cryptic and pseudo-cryptic diversity is another constant issue for morphological taxonomy. Cryptic species are those with very little to no morphological differentiation between species but are genetically distinct. For example, the species of the Rhipsalis group within the genus Halimeda have more than one species that overlap morphologically (Verbruggen et. al. 2005). The red algal species complex Bostrychia radicans Montagne/Bostrychia moritziana Sonder ex Kützing J.Agardh contains seven distinct lineages (Zuccarello and West 2003) that are morphologically indistinguishable. Molecular methods are required to identify cryptic species (Sun et. al. 2012).

\subsection{Molecular identification and barcoding}

Molecular barcoding is a powerful tool for delimiting species in both terrestrial and marine environments (Herbert et. al. 2003). Molecular barcoding is the use of individual or multiple gene sequences (often protein-coding) to identify a specimen to genus or species level. The technique assists morphological species identification, increasing certainty in taxonomic conclusions. Molecular species delimitation has been utilized in the study of brown algae (Ni-Ni-Win et. al. 2011; Vieira et. al. 2014; Buchanan and Zuccarello 2018), red algae (Broom et. al. 2002; Cianciola et. al. 2010; Muangmai et. al. 2014) and green algae (Verbruggen et. al. 2007; Hyang and Myung 2015; Lee and Kim 2015).

Both polymorphic and cryptic species make morphological identification difficult. Polymorphic species have plastic morphology so one species can show many distinct 
morphologies increasing the chance of misidentification, such as many Caulerpa species (Gacia et. al. 1996; Verbruggen et. al. 2014). For example, Lobophora a genus of brown algae previously thought to consist of only a few species (J.V.Lamouroux) Womersley ex E.C.Oliveira, has many genetically distinct entities uncovered by molecular techniques (Vieira et. al. 2014). Padina another genus of brown algae also had many cryptic species identified using molecular barcoding (Ni-Ni Win et. al. 2011). An example of barcodingassisted green algal taxonomy is the refuting the hypothesis that $C$. mexicana (Sonder ex Kützing) and C. taxifolia were morphological variants of the same species (Olsen 1998).

\subsection{Physiological tolerance}

Physiological tolerance limits the distribution of all species. The ability of a species to withstand changes in the environmental conditions makes it more or less adaptable to habitat change during introduction (Zerebecki and Sorte 2011). Invasive species often have broader physiological tolerance limits than native species giving them an advantage in establishment (Higgins and Richardson 2014). Abiotic factors limiting distribution of algae include temperature, light intensity (Gacia et. al. 1996), salinity (Carpelan 1964; Pereira et. al. 2017; Bollen et. al. 2016), pH (Bollen et. al. 2016), water flow and nutrient concentrations. Salinity is a determinant of habitat suitability for aquatic species. For example, in habitats with widely fluctuating salinity, only euryhaline species are present whilst stenohaline species are found in habitats with more consistent salinity as they have tighter tolerance limits (Carpelan 1964). The red alga Acanthophora spicifera had tolerance of 25-40 practical salinity units ( $\mathrm{psu}$ ), but no new growth occurred at $15 \mathrm{psu}$ and high biomass loss occurred at 50 psu. (Pereira et. al. 2017). Light intensity impacts photosynthesis in algae. Too high an intensity induces photoinhibition (Hanelt et. al. 1997). Macroalgae tend to tolerate lower light intensity than seagrasses (Burfiend and 
Udy 2009) and corals (Fabricus 2005), and this increases their competitive ability in turbid coastal ecosystems (Burfiend et. al. 2013).

Temperature is the largest determinant for survival in macroalgae (Graiff et. al. 2015), and summer maximum temperature and winter minimum temperature are more important in determining thermal tolerance limits than the mean temperature (Graiff et. al. 2015). In New Zealand, Undaria pinnatifida sporophytes have temperature tolerances higher than the native kelp Lessonia variegata J.Agardh as $U$. pinnatifida is unstressed at $25^{\circ} \mathrm{C}$ whilst $L$. variegata is severely stressed between $20-25^{\circ} \mathrm{C}$ (Bollen et. al. 2016). This many increase the competitive ability of $U$. pinnatifida with ocean warming (Bollen et. al. 2016). The green alga Valonia utricularis (Roth) C.Agardh has vastly different temperature tolerance dependent on ecotype; the Mediterranean and Atlantic ecotypes can acclimate and maintain photosynthetic efficiency at $15-20^{\circ} \mathrm{C}$ whilst the Indian Ocean ecotype undergoes photoinhibition when grown at 15-20 $\mathrm{C}$ (Eggert et. al. 2003a; 2003b). The lower limit for survival is $5^{\circ} \mathrm{C}$ for the Mediterranean ecotype of $V$. utricularis and $18^{\circ} \mathrm{C}$ for the western Pacific ecotype (Eggert et. al. 2003). Aquarium release of Caulerpa taxifolia has occurred in Japan but establishment has failed, this may be due to winter temperatures being lower than its tolerance limit (Komatsu et. al. 2003). There is little evidence that C. taxifolia populations have different temperature tolerance (Glasby and Gibson 2007). Both Australian native and invasive C. taxifolia have similar growth rates at $15-18^{\circ} \mathrm{C}$, but native Australian $C$. taxifolia had higher growth rates than the invasive at $22-25^{\circ} \mathrm{C}$ (Galasby and Gibson 2007). C. taxifolia tolerance to subtropical temperatures makes both the Australian native and the Mediterranean invasive populations a potential biosecurity threat to northern New Zealand in the future. Caulerpa taxifolia is listed as an "unwanted organism" under the New Zealand Biosecurity Act 1993, due to its history of invasiveness overseas. 


\subsection{Materials and Methods}

\subsection{Sample collection}

Two pet shops in Wellington New Zealand that sell ornamental tropical marine aquarium fish and invertebrates were visited regularly when new coral orders arrived, either monthly or bimonthly. Many corals were also purchased from five online retailers and importers. Algal recruits were collected from the aragonite rock, bivalve shells and concrete to which the corals were attached. A knife was used to break the substrate at the algal holdfast if one was present. Corals that were purchased were monitored and over time algal specimens that grew from the rocks were sampled. Marine aquarium hobbyists across New Zealand were contacted and some donated algal specimens for identification. Coral species and likely origins were recorded along with when the sample was taken (Table S1). A small sample of alga was retained on silica gel for DNA extraction and as a voucher specimen. In some cases, a live specimen was grown in culture for morphological identification or physiological tolerance testing. There were a few cases where no voucher was prepared as only enough tissue for DNA extraction was present.

\subsection{Culture conditions}

To assess the risk of establishment that escaped aquarium algae poses to New Zealand coastal regions, survival of algal samples was tested at New Zealand minimum sea surface temperatures. NZ minimum sea surface temperatures were determined from National Oceanographic and Atmospheric Administration (NOAA) data for Auckland and Wellington (seatemperature.org). Four culture chambers were set to the NZ minimum sea surface temperatures as follows: minimum temperature in Wellington 
winter $\left(11^{\circ} \mathrm{C} \pm 1^{\circ} \mathrm{C}\right)$, minimum temp in Auckland winter $\left(14^{\circ} \mathrm{C} \pm 1^{\circ} \mathrm{C}\right)$, and for the other 2 incubators, $20^{\circ} \mathrm{C} \pm 1^{\circ} \mathrm{C}$ a mid range temperature and a control temperature matching my reef aquaria $25^{\circ} \mathrm{C} \pm 1^{\circ} \mathrm{C}$. HOBO loggers were used to track the temperatures (over 3 days) to insure temperature did not fluctuate more than $1^{\circ} \mathrm{C}$. Fluorescent tubes provided photosynthetically available radiation (PAR) of $10-20 \mu \mathrm{mol}^{-1} \mathrm{~m}^{2-1} \mathrm{~s}^{-1}$. The light cycle was 16:8 light: dark. As light intensity is not equal throughout the chamber, culture dishes with lids were randomly placed throughout the incubator. Sterile dishes with lids were filled with $200 \mathrm{ml}$ sterile (steam sterilized for 10 minutes at $100^{\circ} \mathrm{C}$ ) seawater with quarterstrength modified Provasoli's enrichment medium (West 2005), salinity of 35 psu. 2 drops of $1 \mathrm{mg} / \mathrm{ml}$ germanium dioxide was added per dish to inhibit diatom growth (Lewin 1966).

Algal species identified as frequent arrivals or those traded by hobbyists for nutrient export were selected from aquaculture tanks at $25^{\circ} \mathrm{C} \pm 1^{\circ} \mathrm{C}(\mathrm{K}$. Woodhouse aquaria) for use in the temperature tolerance experiment. The algae samples were cut into 12 approximately equal lengths. Specimens were kept at $25^{\circ} \mathrm{C}$ for 24 hours post-cutting in dishes to allow for recovery. Samples were then randomly allocated to separate sterile dishes, 3 dishes per algal specimen per temperature were place randomly in the chamber. No acclimatization procedure was undertaken.

Survival was measured by bleaching of the alga. The alga turning white (loss of pigments) or disintegration was considered as no survival. Specimens were observed weekly for chloroplast constriction or signs of reproduction. Any changes in morphology were recorded. Any remaining pigmentation was considered as 'survival'. Survival/no survival was determined after 2 weeks. Some specimens were kept for up to 4-weeks to confirm survival/death, due to partial bleaching after 2 weeks. 


\section{$2.3 \quad$ Voucher preparation}

Algal specimens collected within the New Zealand marine aquarium trade were inspected under a dissecting microscope in a dish of distilled water to remove detritus and epiphytes using tweezers. Specimens with excessive overlapping branches had branches removed as required to expose the morphology of the alga and then the specimen was pressed on herbarium paper. Specimens were also preserved in $100 \%$ ethanol if too small to press, and mounted on microscope slides in $60 \%$ Karo (corn syrup) $/ 1 \%$ formalin. Aniline blue staining was used to stain the cytoplasm of ethanol preserved specimens due to pigment loss. The edges of the coverslip were sealed with nail polish after 2 weeks of drying to prevent over drying. Herbariums and slides were numbered to identify the specimen. Vouchers were deposited at Te Papa (Table S1). Micrographs were taken using an Olympus BX63 microscope with a DP80 camera (Olympus). Herbarium photographs were taken using an iPhone 7. Figures were annotated in Canvas 5 (Canvas V5.0.1).

\subsection{Molecular identification}

Some algae were identified morphologically, however morphological variability and lack of characters in many algal groups makes DNA barcoding a superior method of identification (Cianciola et. al. 2010). When used alongside morphological identification, molecular barcoding increases the certainty in species identification (Manoylov 2014). 


\subsection{DNA extraction}

Each algal specimen was cleaned under a dissecting microscope to remove potential contaminants and ensure that it was a single specimen. A portion of the most recent growth was removed and extracted using either: a modified CTAB protocol (Zuccarello and Lokhorst 2005), or a Chelex extraction protocol for small tissues (Goff and Moon 1993). DNA extracts were stored at $-20^{\circ} \mathrm{C}$.

Extracted DNA was amplified depending on preliminary identification of the alga and the available databases. Genes used were as follows: for siphonous green algae (Caulerpa, Bryopsis, Derbesia and Riphidosiphon) partial plastid elongation factor A (tufA) gene was used, primers Caul tufA-forward and Caul tufA-reverse were used (Famá et. al. 2002), and in some cases partial ribulose-1,5-bisphosphate carboxylase/oxygenase large subunit $(r b c \mathrm{~L}$ ) gene using primers $r b c \mathrm{~L} 712 \mathrm{~F}$ and $r b c \mathrm{~L}$ 904R (Lagourgue et. al. 2018). For species within the Cladophorales, such as Chaetomorpha, Cladophora and Valonia, partial large subunit ribosomal RNA (LSU) using primers C'1 forward and D2 reverse were used (Hassouna et. al. 1984). For red algae, partial cytochrome oxidase subunit 1 ( $\operatorname{cox} 1)$ gene was used, using primers GazF1 and GazR1 (Saunders 2005), or partial $(r b c \mathrm{~L})$ gene using primers $765 \mathrm{~F}$ and $1150 \mathrm{R}$ (Freshwater et. al. 1994). For brown algae, partial cytochrome oxidase subunit 3 ( $\operatorname{cox} 3)$ gene was used with primers cox3 44F and cox3 739R (Vieira et. al. 2014). Primers and amplicon lengths are shown in (Table S2).

\subsection{Polymerase chain reaction}

The PCR reaction volume was $30 \mu \mathrm{L}$ and consisted of $\sim 0.1-0.4 \mu \mathrm{g}$ genomic DNA, $1.25 \mathrm{nmol}$ of each dNTP, $7.5 \mathrm{pmol}$ of each primer, $1 \times$ ammonium reaction buffer, 
$2.5 \mathrm{mM} \mathrm{MgCl} 2,4-5 \mu \mathrm{L}$ of $0.25 \%$ bovine serum albumin and 1 unit of Taq polymerase (Bioline, Meridian Bioscience Inc. USA)

The standard amplification conditions were as follows: denaturing at $94^{\circ} \mathrm{C}$ for 5 min, 36 cycles of denaturing at $94^{\circ} \mathrm{C}$ for $1 \mathrm{~min}$, annealing at $45^{\circ} \mathrm{C}$ for $30 \mathrm{sec}$ and extension at $72^{\circ} \mathrm{C}$ for $1 \mathrm{~min}$ and a final extension at $72^{\circ} \mathrm{C}$ for $5 \mathrm{~min}$. Primers and primer specific alterations to the amplification procedure are shown in (Table S2).

Agarose gel electrophoresis was done on the PCR products to identify successful amplification of the target region. Electrophoresis was in $1 \%$ agarose with $0.5 \mathrm{TBE}$, at 100 volts, using $1 \mu \mathrm{L}$ loading buffer (glucose and bromophenol blue) to $3 \mu \mathrm{L}$ PCR reaction. Gels were electrophoresed for 30 minutes with a $50 \mathrm{bp}$ ladder (Bioline) to determine the size of the amplified DNA. Gels were then stained in ethidium bromide for 10-15 minutes, rinsed in water, and photographed under UV light.

Successful PCR products were prepared for sequencing using Exo Sap-IT (USB Corporation) per PCR product. This involved incubated the PCR product with 0.5U ExoSapIT at $37^{\circ} \mathrm{C}$ for $20 \mathrm{~min}$, then heating to $80^{\circ} \mathrm{C}$ for $10 \mathrm{~min}$. Cleaned products were sequenced commercially (Macrogen Inc. Seoul, Korea). Sequences were edited using the Geneious software package (Geneious Prime.2019.2.1) (https://www.geneious.com) to remove primers and low quality sequence.

Sequences were queried against the National Center for Biotechnology Information sequence database (NCBI) Genbank using the Basic Local Alignment Search Tool (BLAST) (Johnson et. al. 2008), to confirm that the sequences were of the gene of interest. The Blast top hit was recorded along with the E value and the sequence identity percentage. BLAST searching compares a query sequence with those in the NCBI database to find regions of similarity. BLAST then calculates the statistical significance of the high sequence identity matches, reporting significance as "E" values. 
Alignments were built for each gene and genus of algae sampled using the top 5 Blast hits for each of our sample sequences, Genbank sequences for the named species in the genus of the top Blast hit for each sample sequence were included. In some cases, examples of closely related genera were included in the alignment. Alignments were made using MAFFT with scoring matrix 200PAM/K=2, gap open penalty 1.53 , offset value 0.123 , implemented in Geneious. Alignments of protein coding genes were translated and cut to start at the first codon position and end at third codon position to allow for codon position partitioning.

Maximum Likelihood analyses were implemented using IQ-tree (Trifinopoulos et. al. 2016). IQ-tree was used to select the molecular evolution models (Modelfinder) (Kalyaanamoorthy et. al. 2017) and construct (ML) trees with 1,000 bootstrap replicates. Genes were partitioned by codon where appropriate. Models selected for each data set were selected using the BIC criterion and are presented in Table S3. Trees were annotated in Figtree v1.4.4 (Rambaut 2010) and Canvas draw (Canvas Draw V5.0.1). Sequences were deposited in Genbank, and accession numbers presented in Table S1.

\subsection{Species determination}

To delimit species using pairwise differences, we used a working hypothesis of $2 \%$ difference equals a potentially different species, and $<2 \%$ is the same species. This hypothesis was used for $\operatorname{cox} 1$ in red algae, $c o x 3$ in brown algae, $r b c \mathrm{~L}$ in red algae, $t u f \mathrm{~A}=$ in green algae except for Caulerpa spp., and the LSU gene in the Cladophorales except for Cladophora. The LSU gene in the Cladophorales has little divergence between some lineages, e.g., there was $<1 \%$ pairwise difference between species in the Cladophora albida/serica clade (Boedeker et. al. 2016). We used a hypothesis that $>1 \%$ pairwise difference indicates a different species and $<1 \%$ indicates the same species in 
Cladophora. For Udotaceae $r b c \mathrm{~L}$ we used with $>4 \%$ pairwise difference to indicate different species as this is an average difference between species within Rhipidosiphon (Coppejans et. al. 2011). TufA in green algae is conserved, and within the genus Caulerpa there is little variation. For example, the pairwise distance values between some species is very low: between $C$. taxifolia and C. distichophylla it is $0.24 \%, C$. brachipus and $C$. subserrata it is $0.2 \%$ distance, however $C$. mexicana have $0.4 \%$ within species pairwise difference (Famá et. al. 2002). As pairwise distance between Caulerpa spp. is low we used a hypothesis of $>0.2 \%$ pairwise difference indicates a different species and $<0.2 \%$ pairwise difference the same species. 


\subsection{Results}

\subsection{Identification red algae}

Hypnea spp.

Hypnea spp. specimens found on coral rocks were branched red-dark thalli with frequent indeterminate branching and branch tips having a single apical cell (not shown). Specimens sectioned had a single layer of small rounded cortical cells and large unpigmented hexagonal shape medullary cells; a central axial cell was also present. Sample A55 had cystocarps present (Fig. 1A, B). Some samples (A69) showed less frequent indeterminate branching of sample (Fig. 1C). Other samples were only small fragments (A95)(Fig. 1c). Micrographs of samples A101, A94, A97 were included in (Fig. S3).

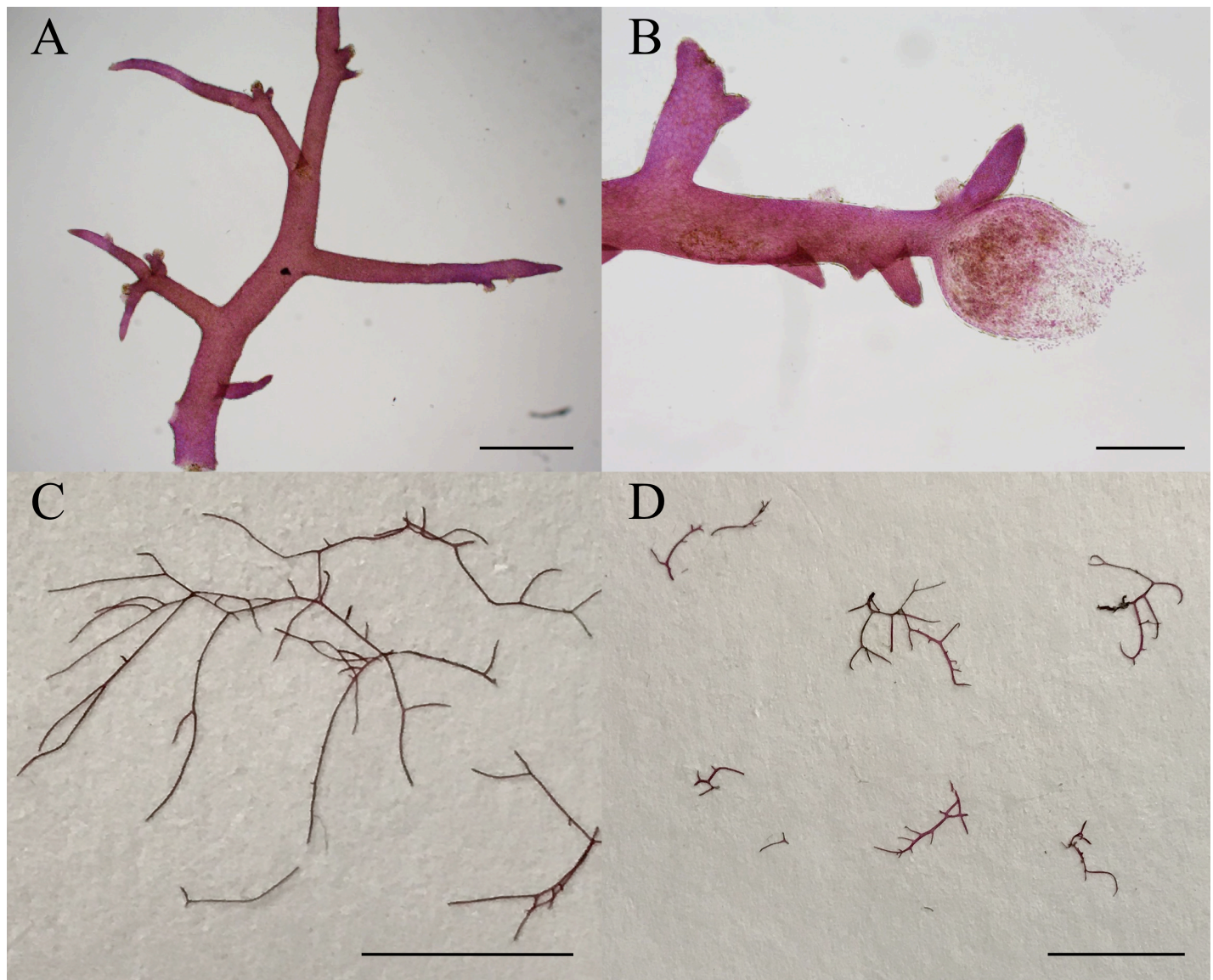

Figure 1. Examples of Hypnea wynnei. Herbarium and photomicrographs; $A=A 55$, scale bar $=1 \mathrm{~mm}, \mathrm{~B}=\mathrm{A} 55$ with cystocarp, scale bar $=400 \mu \mathrm{m}, \mathrm{C}=\mathrm{A} 69$, scale bar $=2 \mathrm{~cm}, \mathrm{D}=$ A95, scale bar $=1 \mathrm{~cm}$, 
Specimens A55, A69, A95 and A97 are within a clade containing Hypnea wynnei Nauer, Cassano \& M.C.Oliveira (KX426549, KX426547, KX426551), H. stellulifera (J.Agardh) Yamagishi \& Masuda (HQ422721) and Hypneocolax stellaris subsp. oreintalis Børgesen (HQ422720) with high bootstrap support (100\%)(Fig. 2). Aligned sequences show $0-0.2 \%$ differences in cox 1 between the samples and their top Blast hit, H. wynnei (KX426549) from Brazil. I designated samples A55, A69, A95 and A97 as $H$. wynnei.

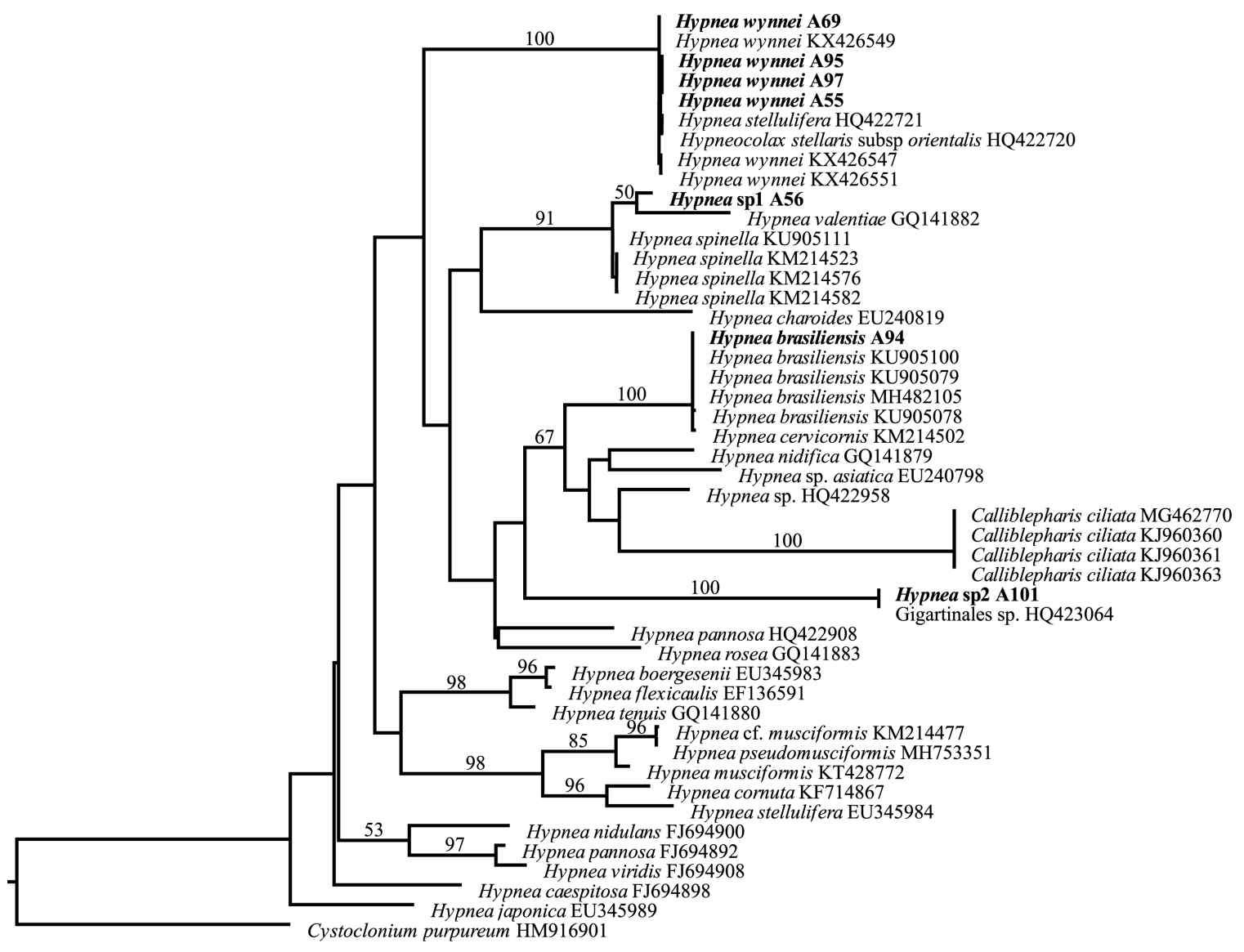

Figure 2. Maximum-likelihood tree of Hypnea spp. using cox1 sequences. Samples A55, A56, A69, A94, A95, A97 and A101 shown. Cystoclonium purpureum (HM916901) was used as the outgroup. Only bootstrap values $>50 \%$ displayed. Scale bar $=0.3$ substitutions per site. 
Sample A56 is sister to Hypnea valentiae (Turner) Montagne (HQ141882) but with low bootstrap support (50\%), they are within a clade containing Hypnea spinella (C.Agardh) Kützing with high bootstrap support (91\%). A56 has 6.45\% pairwise difference to its sister Hypnea valentiae (HQ141882) but has $2.8 \%$ pairwise difference in cox1 to $H$. spinella (KU905111) its closest pairwise sequence and top Blast hit from Bahia, Brazil. I designate sample A56 as Hypnea sp1. Sample A94 groups with Hypnea brasiliensis P.B.Jesus, Nauer and J.M.C.Nunes with high bootstrap support (98\%) and this clade also contains a sequence identified as Hypnea cervicornis J.Agardh (KM214502). Sample A94 sample has $1.13 \%$ pairwise difference in cox 1 to its closest Genbank sequence and top Blast hit H. brasiliensis (KU905079), also from Brazil. I designated sample A94 as H. brasiliensis. Sample A101 is sister to a sequence designated as Gigartinales sp. (HQ423064) with high support bootstrap, and 100\% percent identity to that sequence. I designated sample A101 as Hypnea sp2, the same species as Gigartinales sp. (HQ423064).

Chondrophycus spp.

The three Condrophycus sp. samples found on maricultured coral rocks were branching, flattened with a holdfast attaching then to the substrate. Apical pits were present (Fig. 3B, C). Specimen A1 (Fig. 3A) was preserved in ethanol resulting in pigment loss and shriveling, live specimen had dark red pigmentation. 


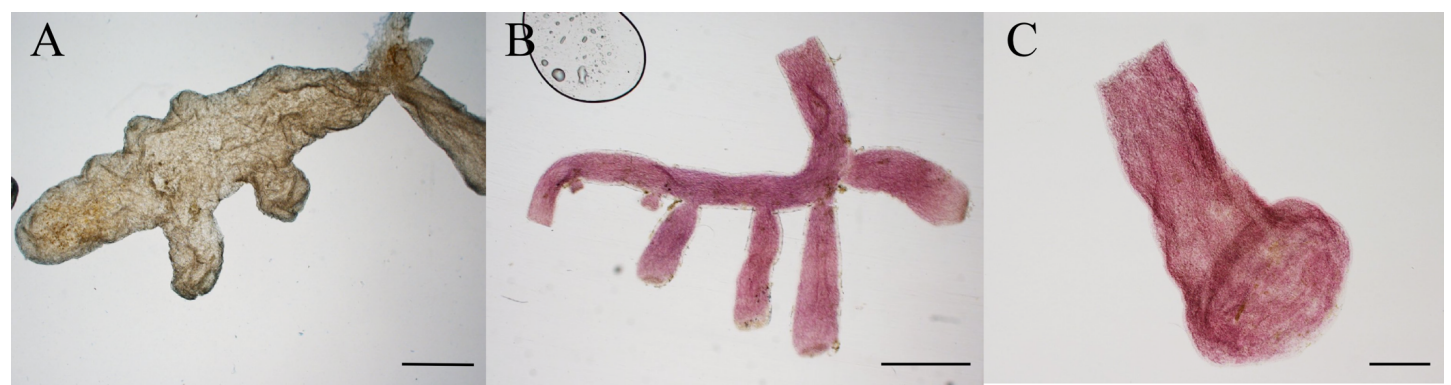

Figure 3. Examples of samples of Chondrophycus sp. Photomicrographs. A = A1, preserved specimen, scale bar $=1 \mathrm{~mm}, \mathrm{~B}=\mathrm{A} 107$, scale bar $=1 \mathrm{~mm}, \mathrm{C}=\mathrm{A} 8$ branch tip, scale bar $=400 \mu \mathrm{m}$

Sample A1 is sister to Chondrophycus sp. (KX258817) from the Loyalty Islands, New Caledonia based on cox 1 sequences with moderate bootstrap support (79\%)(Fig. 4). The sample has $3.75 \%$ difference in cox 1 to Chondrophycus sp. (KX258817) its closest pairwise sequence and top Blast hit. I designated sample A1 as Chondrophycus sp1. Sample A107 is most closely related to Chondrophycus sp. (HQ423056) from Hawaii with moderate bootstrap support (85\%). The sample has $7.72 \%$ pairwise difference in cox1 to Chondrophycus sp. (HQ423056) its top Blast hit. I designated sample A107 as Chondrophycus sp2. 


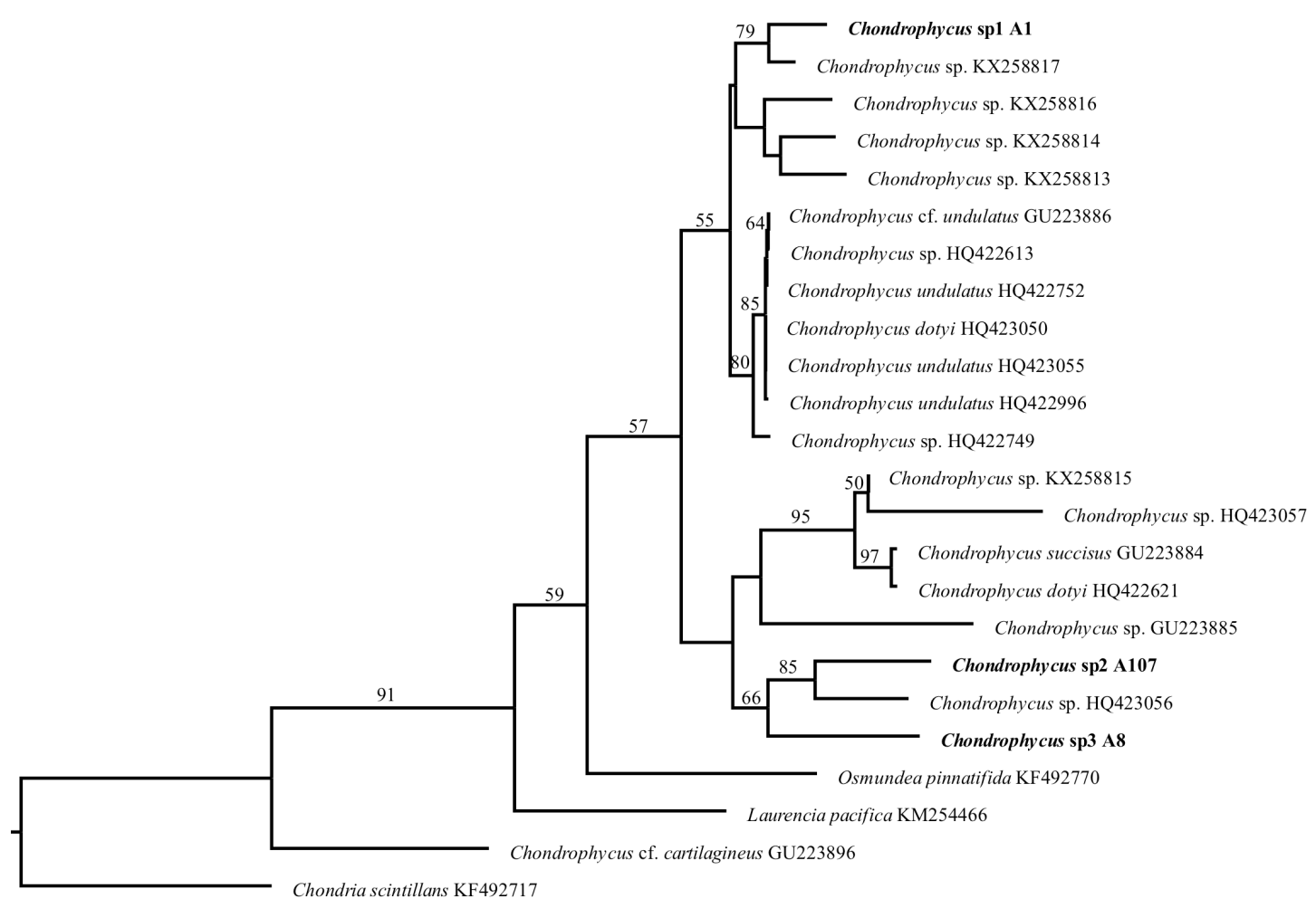

Figure 4. Maximum-likelihood tree of Chondrophycus spp. using cox 1 sequences. Samples A1, A8 and A107 shown. Chondria scintillans G.Feldmann (KF492717) was used as the outgroup. Only bootstrap values $>50 \%$ displayed. Scale bar $=0.3$ substitutions per site.

Sample A8 is sister to a clade containing A107 and Chondrophycus sp. (HQ423056) with low bootstrap support (66\%) and 9.3\% pairwise difference between A8 and Chondrophycus sp. (HQ423056). Sample A8 has 8.33\% pairwise difference in cox 1 to the top Blast hit Chondrophycus sp. (KX258815), with which is does not group in the phylogenetic analysis. I designated Sample A8 as Chondrophycus sp3.

Laurencia spp.

Samples A96 and A102 were found on rock associated with wild collected Zoanthus colonies, they had distinctive apical pits and thin intertwining branches, having a matted appearance, branches had multiple attachment points to the substrate. Specimen A96 (Fig. 5A) was preserved in ethanol and has lost the deep red pigmentation present in live specimens. Sample A102 (Fig. 5B) had a purplish pigmentation when fresh. 


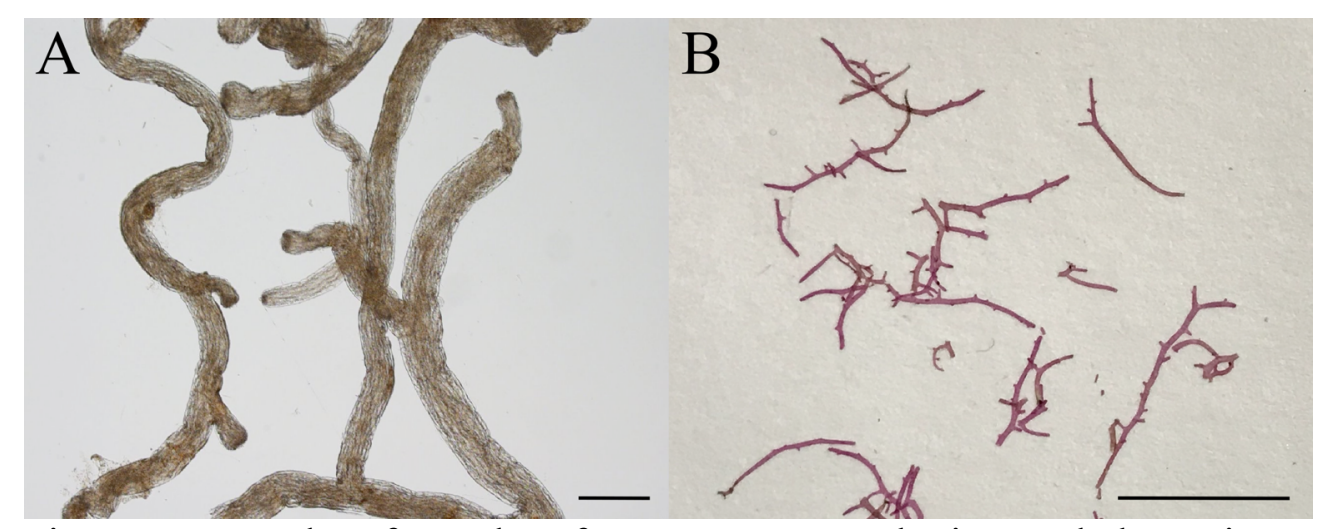

Figure 5. Examples of samples of Laurencia sp. Herbarium and photomicrograph; A = Laurencia sp. A96, scale bar $=400 \mu \mathrm{m}, \mathrm{B}=$ Laurencia $\mathrm{sp}$. A102, scale bar $=1 \mathrm{~cm}$.

Sample A96 is within a clade based on cox 1 sequences containing Laurencia nidifica Hauck with low bootstrap support (<50\%) (Fig. 6). A96 has 5.6\% pairwise difference to its sisters Laurencia nidifica (HQ422750) and 6.04\% difference to $L$. nidifica (GU223888). Aligned sequences of cox 1 show 5.52\% difference between A96 and Laurencia saitoi Perestenko (KM254876) its closest pairwise sequence and top Blast hit from Monterey, California, USA. I designated sample A96 as Laurencia sp1. 


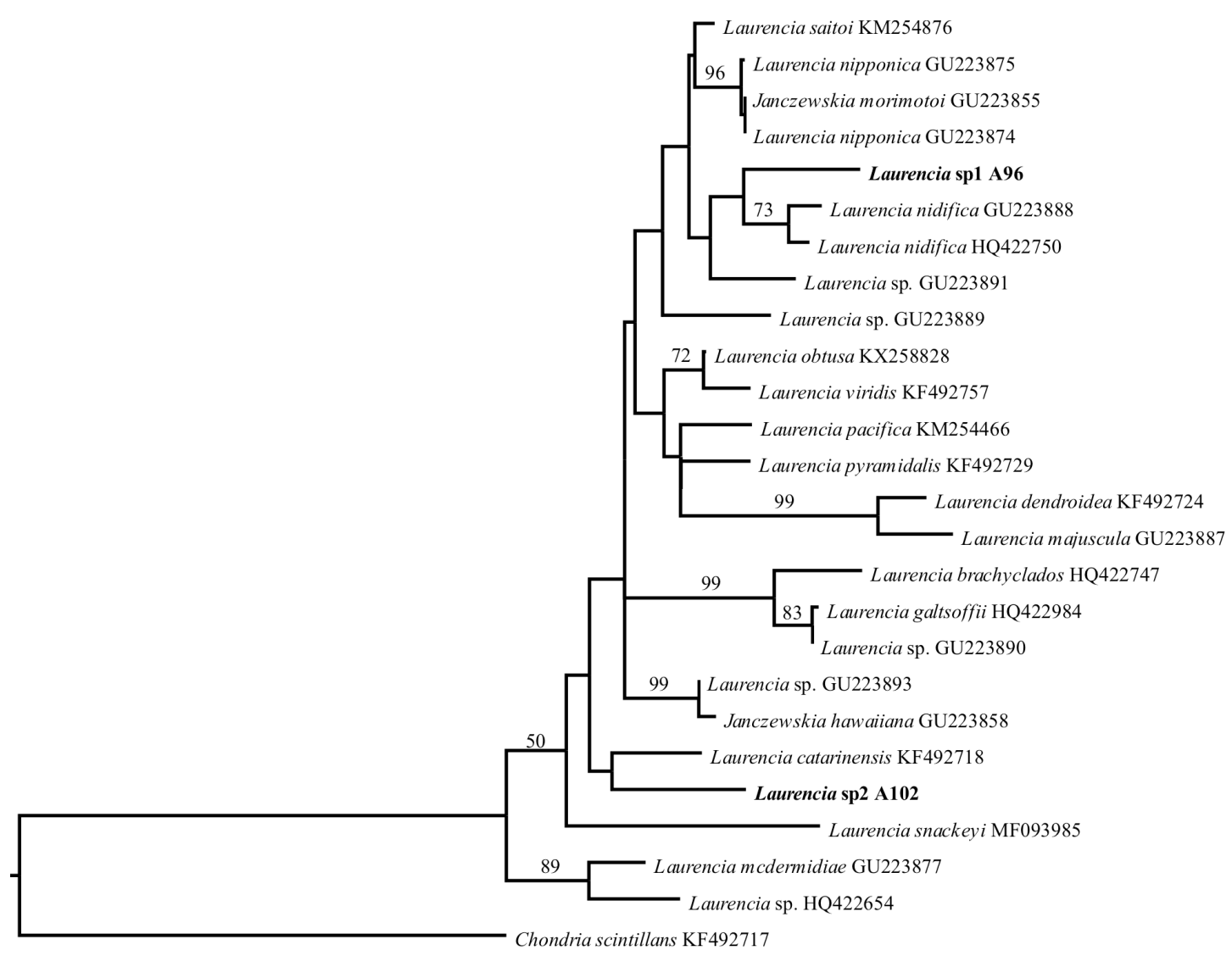

Figure 6. Maximum likelihood tree of Laurencia spp. using cox1 sequences. Samples A96 and A102 shown. Chondria scintillans (KF492717) was used as the outgroup. Only bootstrap support values $>50 \%$ displayed. Scale bar $=0.3$ substitutions per site.

Sample A102 is sister to Laurencia catarinensis Cordeiro-Marino and Fujii (KF49718) but is unsupported $(<50 \%)$, and $6.26 \%$ pairwise difference between the sequences. A102 is $5.96 \%$ different in $\operatorname{cox} 1$ to its closest pairwise sequence, with which it does not group in the ML tree, and top Blast hit Laurencia sp. (GU223893) from Oahu, Hawaii, USA. I designated sample A102 as Laurencia sp2. 
Pterocladiella spp.

Samples of Pterocladiella either arose from a single holdfast, A68 (Fig. 7A), or were stoloniferous, A93 (Fig. 7B). Samples had a flattened (Fig. 7C) single lobed or branching thallus with rounded tips and dark reddish-brown pigmentation.

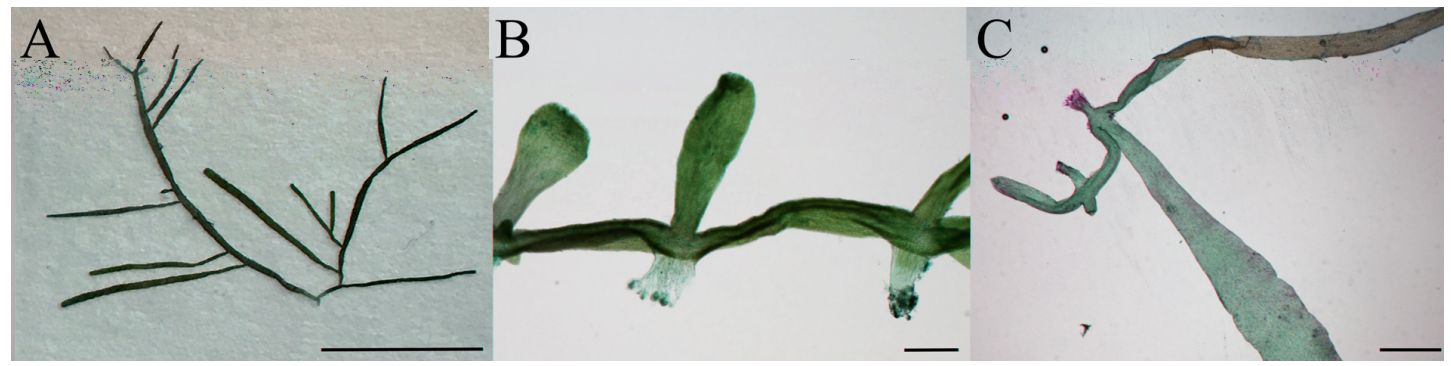

Figure 7. Examples of Pterocladiella spp. photomicrographs; $A=A 68$, scale bar $=2 \mathrm{~cm}$, $\mathrm{B}=$ A93, scale bar $=400 \mu \mathrm{m}, \mathrm{C}=\mathrm{A} 98$, scale bar $=1 \mathrm{~mm}$.

Samples A68 and A93 were grouped with high bootstrap support (92\%) and had identical in cox 1 sequences (Fig. 8). The samples are within a clade containing Pterocladiella caerulescens (Kützing) Stantelices \& Hommersand (KX557255) their top Blast hit with high support bootstrap (97\%). Samples A68 and A93 have 0.37\% pairwise difference in cox 1 to their closest Genbank sequence, P. caerulescens (KX557255) from Port Dauphin, Madagascar. I designated both A68 and A93 as Pterocladiella caerulescens. 


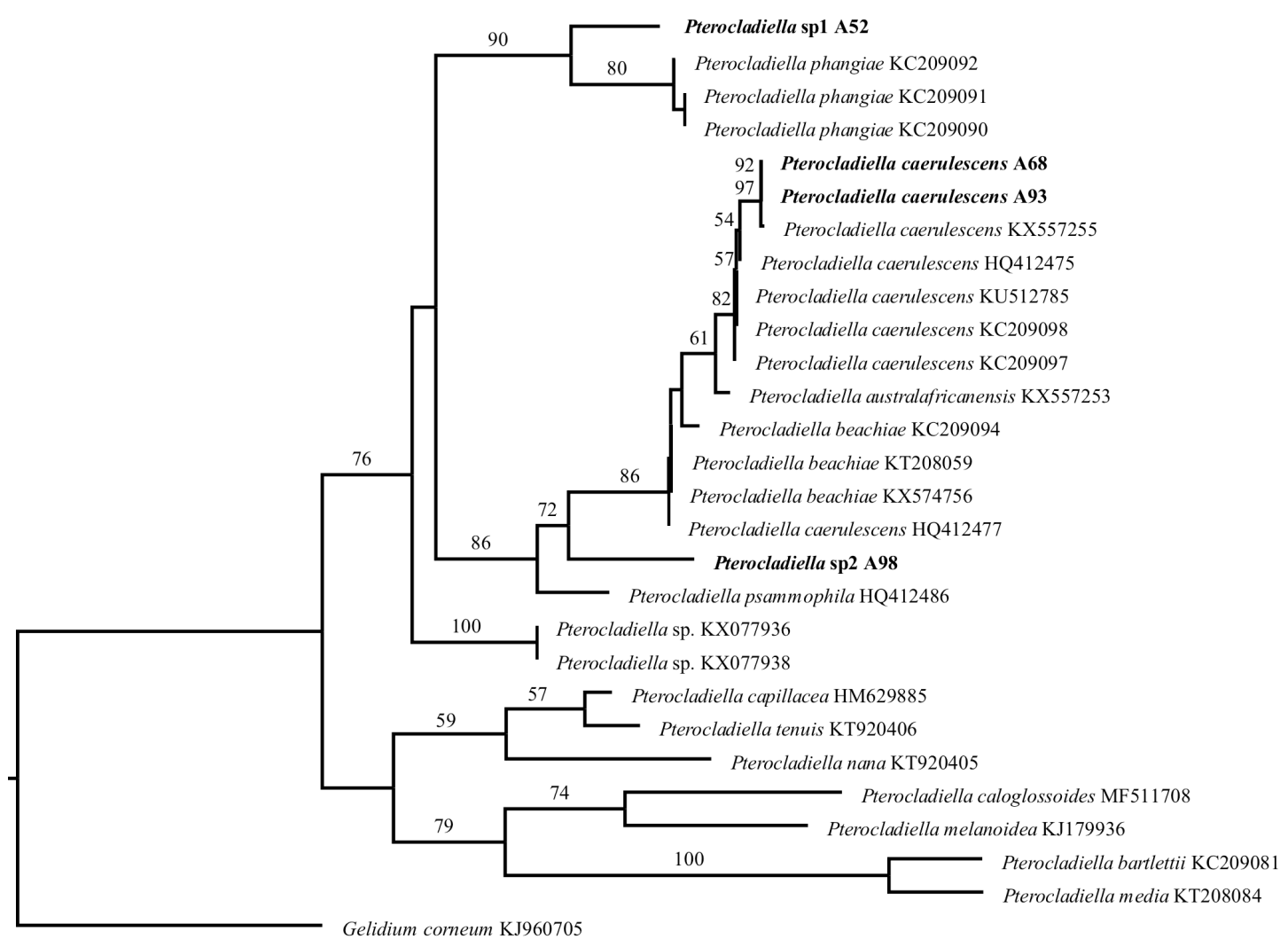

Figure 8. Maximum likelihood tree of samples of Pterocladiella spp. using cox1 sequences. Samples A52, A68, A93 and A98 shown. Gelidium corneum (Hudson) J.V.Lamouroux (KJ960705) was used as the outgroup. Only bootstrap values $>50 \%$ displayed. Scale bar $=0.2$ substitutions per site.

Sample A52 is within a clade containing Pterocladiella phangiae J.Sohrabipour, P.-E Lim and C.A.Maggs with high bootstrap support (90\%). A52 has 9.39\% pairwise difference in cox 1 to the closest Genbank sequence and top Blast hit Pterocladiella phangiae (KC209092) from Port Dickson, Malaysia. I designated sample A52 as Pterocladiella sp1. Specimen A98 is sister to P. beachiae Freshwater and P. caerulescens and has $8.29 \%$ pairwise difference in $\operatorname{cox} 1$ to the closest Genbank sequence and top Blast hit P. beachiae (KT208059) from Espirito Santo, Brazil. I designated sample A98 as Pterocladiella $\mathrm{sp} 2$. 
Peyssonnelia spp.

The Peyssonnelia samples found in this study were encrusting red thalli conforming tightly to the rock substrate (Figs. 9B, C) or growing outwards from the substrate, A104 (Fig. 9D). They have a row of apical cells on the margin of the thallus. Sample A53 (Fig. 9A) was fixed in ethanol resulting in loss of red pigment.

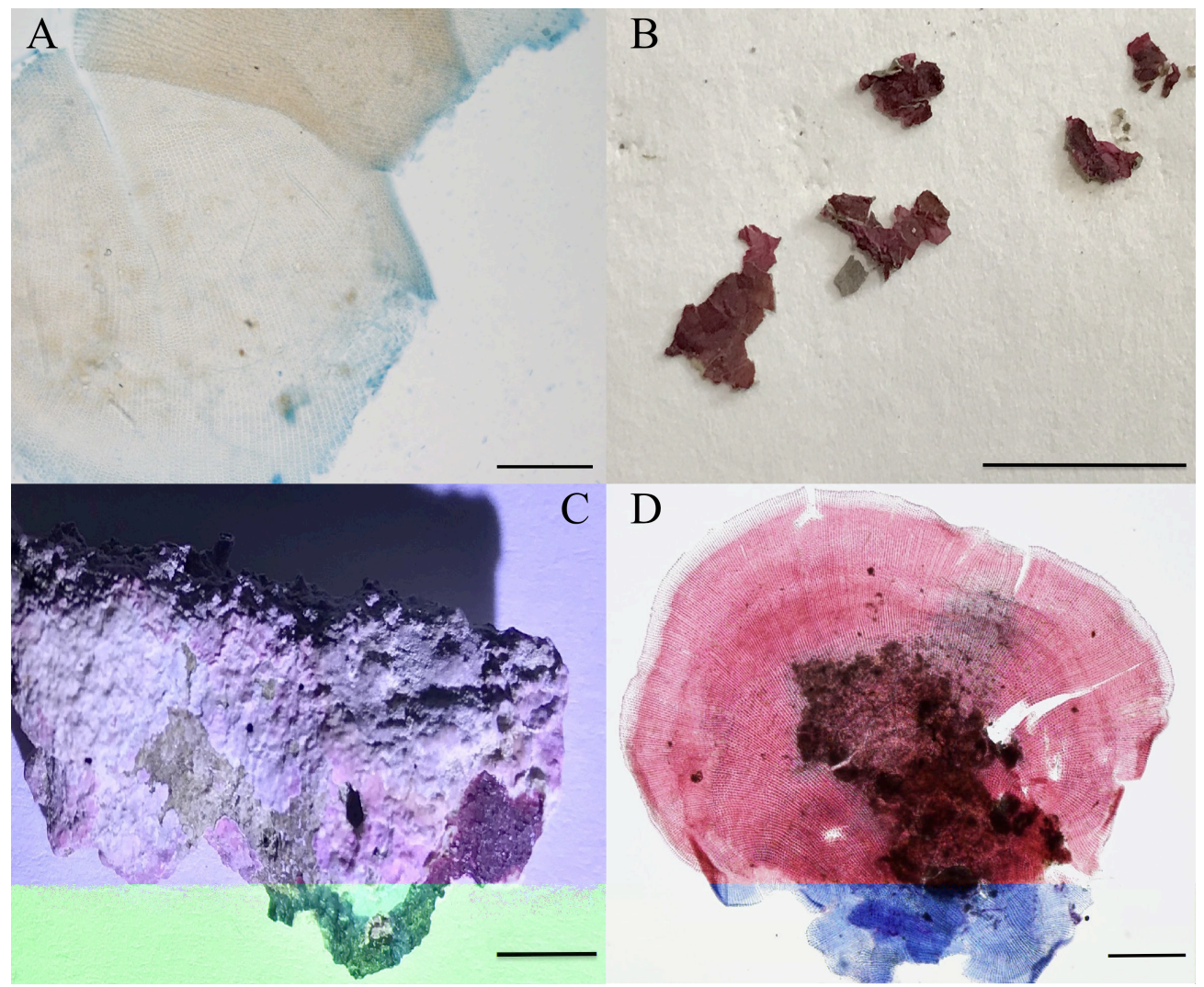

Figure 9. Examples of samples of of Peyssonnelia spp., herbarium and photomicrographs; A $=$ A53, stained with aniline blue, scale bar $=200 \mu \mathrm{m}, \mathrm{B}=$ herbarium of A70, scale bar $=1 \mathrm{~cm}, C=A 86$, scale bar $=1 \mathrm{~cm}, \mathrm{D}=\mathrm{A} 104$, scale bar $=400 \mu \mathrm{m}$.

Sample A86 is within a clade, based on cox 1 sequence analysis, containing Peyssonnelia atropurpurea P.Crouan and H.Crouan (JX969703), Peyssonnelia sp. (KM254486, KM254380, KM254509, KM254687 and KM254773) with moderate bootstrap support (70\%) (Fig. 10). Sample A86 is $8.31 \%$ different in cox 1 to Peyssonnelia sp. (KM254773), its closest pairwise sequence and top Blast hit. I designated sample A86 as Peyssonnelia sp1. 


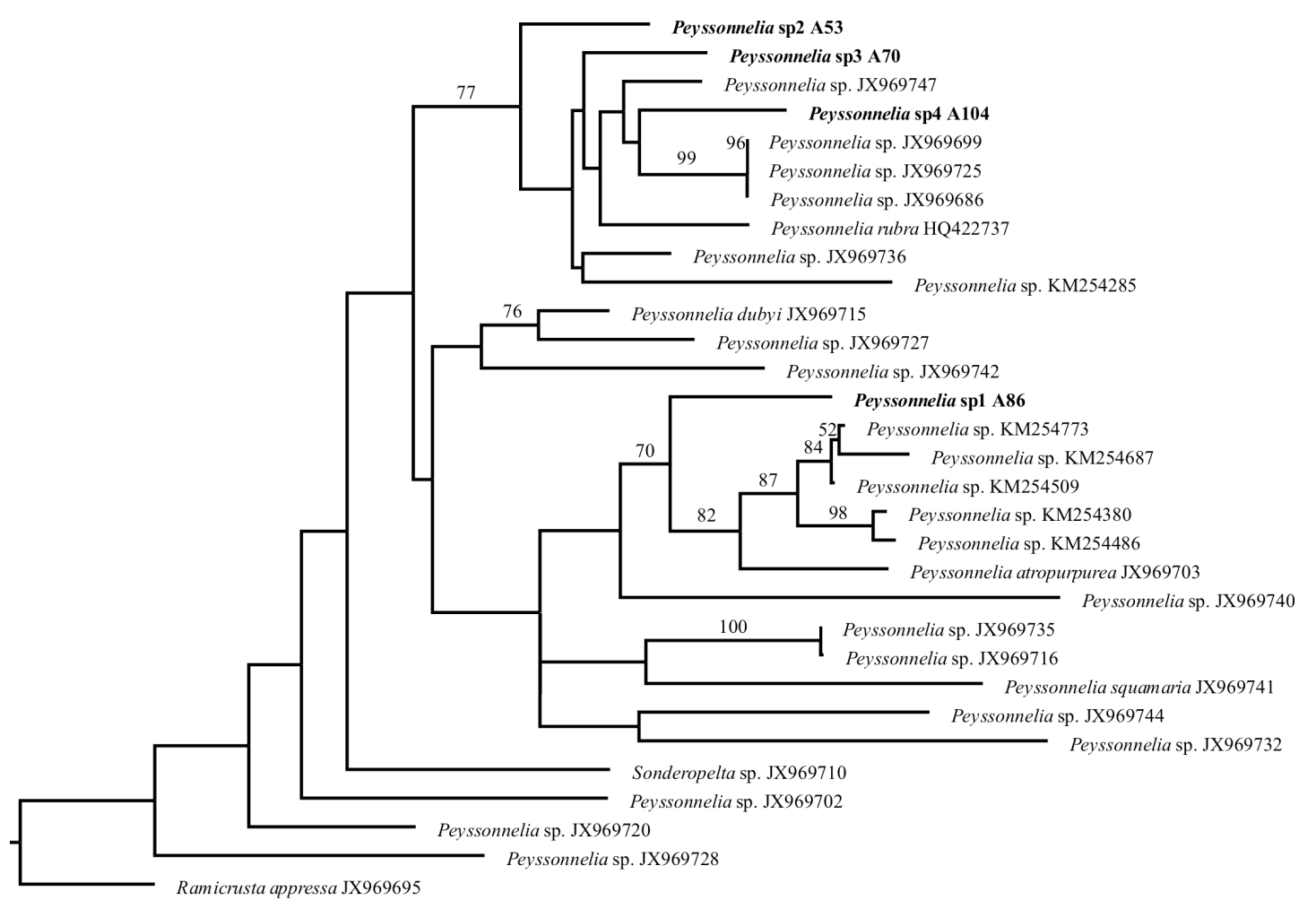

Figure 10. Maximum-likelihood tree of Peyssonnelia spp. using cox 1 sequences. Samples A53, A70, A86 and A104 shown. Ramicrusta apressa (JX969695) was used as the outgroup. Only bootstrap support values $>50$ displayed. Scale bar $=0.6$ substitutions per site.

Samples A53 and A70 are within a clade containing many sequences with moderate support (77\%). Sample A53 has 7.63\% pairwise difference in cox 1 to closest Genbank sequence and top Blast hit Peyssonnelia rubra (HQ422737). I designate sample A53 as Peyssonnelia sp2. Sample A70 has $7.28 \%$ difference in cox1 to Peyssonnelia sp. (JX969736); its closest pairwise sequence, and top Blast hit. I designated sample A70 as Peyssonelia sp3. Sample A104 is within a clade, without support, containing Peyssonnelia sp. (JX969686, JX969725 and JX969699). A104 has 8.6\% pairwise difference in cox 1 to the top Blast hit Peyssonnelia sp. (JX969686) however it has 8.3\% pairwise difference to sequences Peyssonnelia sp. (JX969747, JX969725 and JX969699). I designated sample A104 as Peyssonnelia sp4. 


\section{Ramicrusta sp.}

Samples A84 and A92 were not large enough to preserve as vouchers, as the entire samples were required for DNA extraction. The samples were crustose reddish brown thalii on aragonite substrate.

Samples A84 and A92 (Fig. 11) group with high bootstrap support (100\%) and have identical cox 1 sequences. The samples are sister to Ramicrusta appressa K.R.Dixon (JX969695, JX969707) with moderate support bootstrap (76\%). The closest Genbank sequence and Blast hit for samples A84 and A92 was Ramicrusta apressa (JX969695) from Teloa, Vanuatu with $6.2 \%$ difference in $\operatorname{cox} 1$ for A84 and $6.61 \%$ difference in cox 1 for A92. This difference in identity is due to samples A84 and A92 having different sequence lengths after sequence editing. I designated samples A84 and A92 as Ramicrusta sp. 


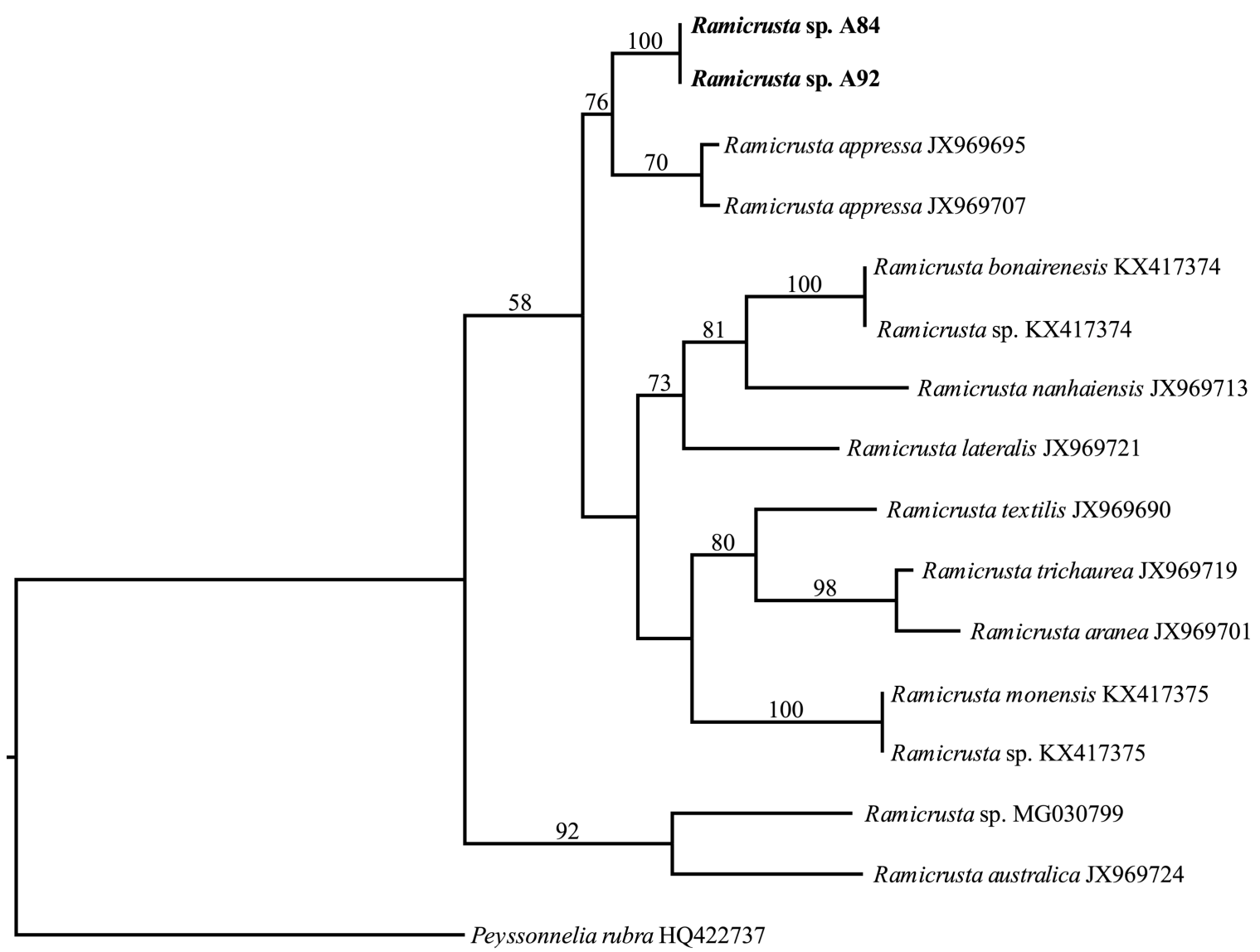

Figure 11. Maximum-likelihood tree of Ramicrusta spp. using cox1 sequences. Samples A84 and A92 shown. Peyssonnelia rubra (HQ422737) was used as the outgroup. Only bootstrap support values $>50 \%$ displayed. Scale bar $=0.2$ substitutions per site.

\section{Meredithia sp.}

Samples A3 (Fig. 12) had a deep reddish-purple thallus with rounded margins and a ruffled appearance. The voucher specimen was $6 \mathrm{~mm}$ in diameter and is a small cutting from a $4 \mathrm{~cm}$ diameter specimen found on glass at a retailer in Lower Hutt, Wellington. 


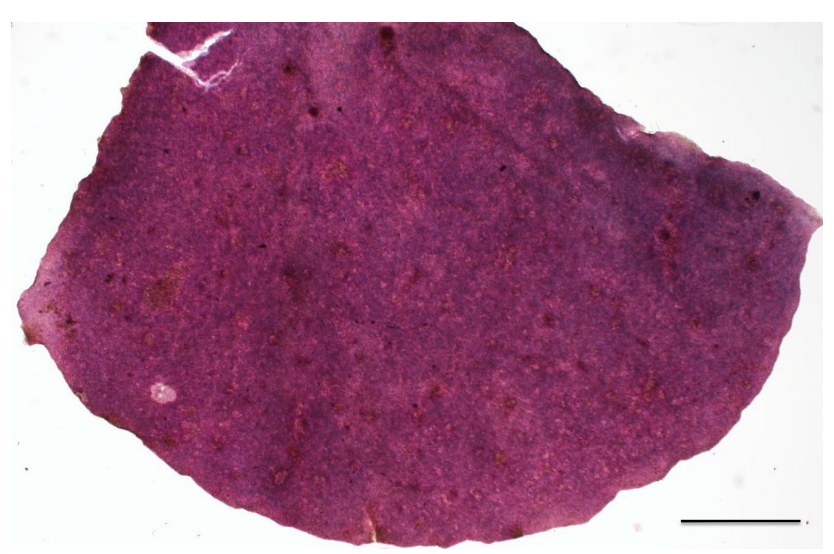

Figure 12. Sample of Meredithia sp. A3. Photomicrograph. Scale bar $=1 \mathrm{~mm}$.

Sample A3 groups with Meredithia sp. (KC157609) with moderate bootstrap support (83\%) (Fig. 13). The sample is grouped with three named species: M. kraftii, $M$. norfolkensis and M. nutleorum with moderate bootstrap support (73\%). Aligned sequences shows $0.45 \%$ difference in cox 1 between sample A3 and Meredithia sp. (KC157609), its closest pairwise difference and top Blast hit. I designated sample A3 as Meredithia sp., the same species as Meredithia sp. (KC157609) from Mindoro Oriental, Philippines. 


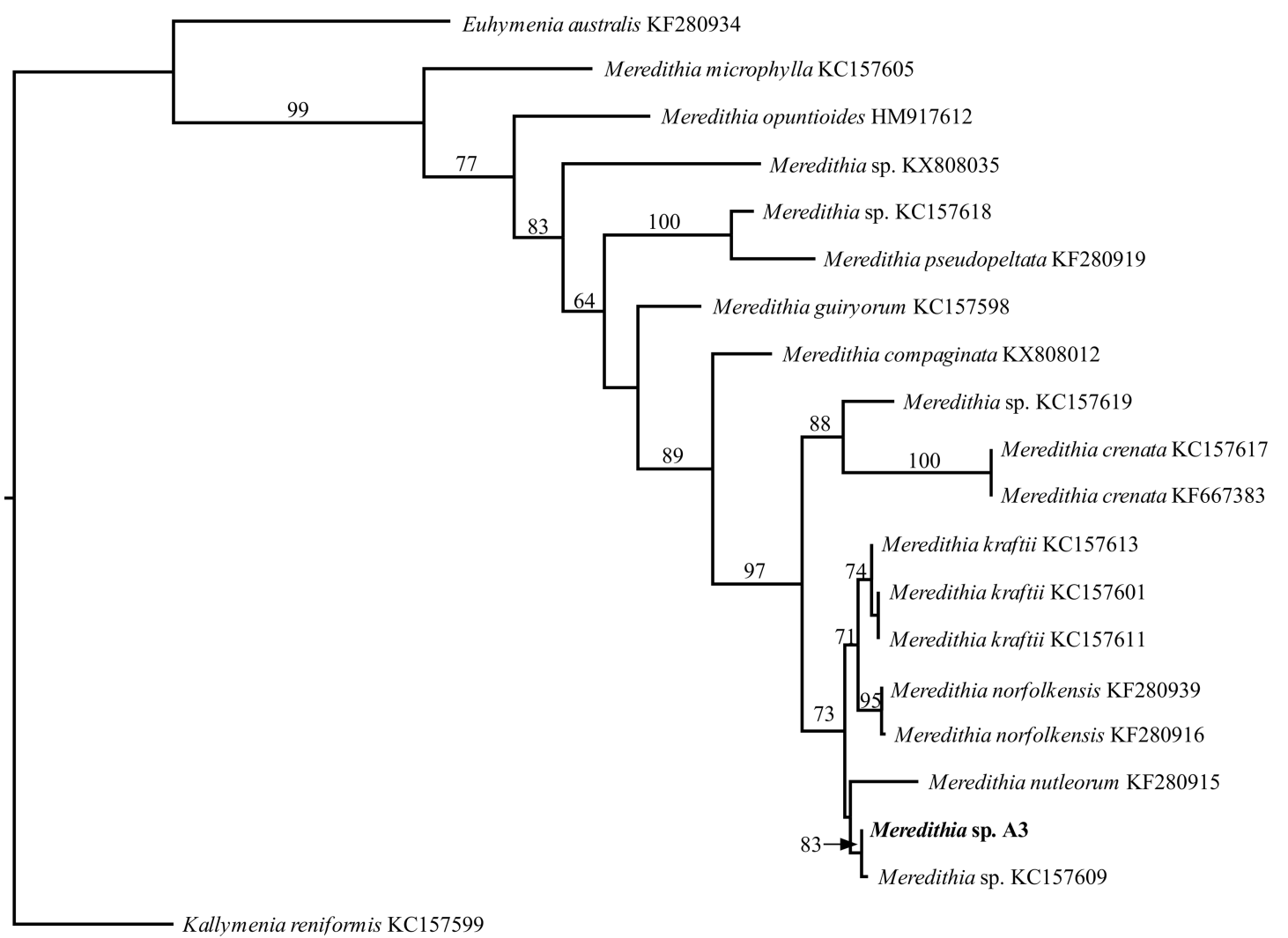

Figure 13. Maximum-likelihood tree of of Meredithia spp. using cox1 sequences. Specimen A3 shown. Kallymenia reniformis (Turner) J.Agardh (KC157599) was used as the outgroup. Only bootstrap support values $>50 \%$ displayed. Scale bar $=0.2$ substitutions per site.

Leptofauchea $\mathrm{sp.}$

Sample A67 (Fig. 14) was donated by a marine aquarium hobbyist in Auckland (Suppl. Table 1), the specimen had light red pigmentation, a flattened branching thallus, branching was slightly constricted near their bases, tips were rounded, and paler than older tissue. A single holdfast was present. 


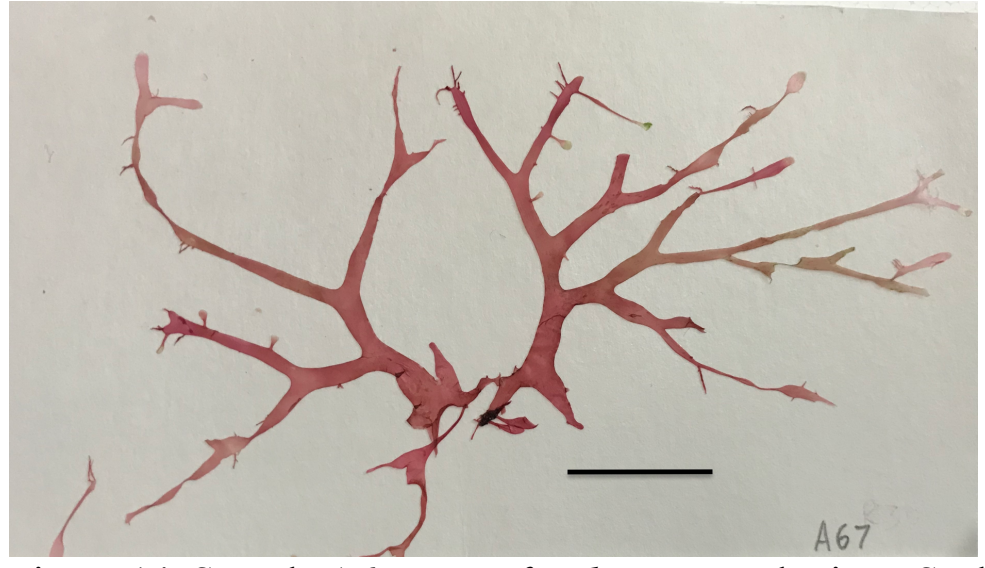

Figure 14. Sample A67, Leptofauchea sp. Herbarium. Scale bar $=2 \mathrm{~cm}$.

Sample A67 was within a clade containing Leptofauchea cocosana Filloramo and G.W.Saunders (KR140330), Leptofauchea leptophylla (Segawa)(KF547030) and samples designated as Rhodymeniales sp. with moderate bootstrap support (75\%)(Fig. 15). A67 has $8.65 \%$ pairwise difference in cox 1 to the top Blast hit Leptofauchea leptophylla (KF547030) from South Korea. I designated sample A67 as Leptofauchea sp. 


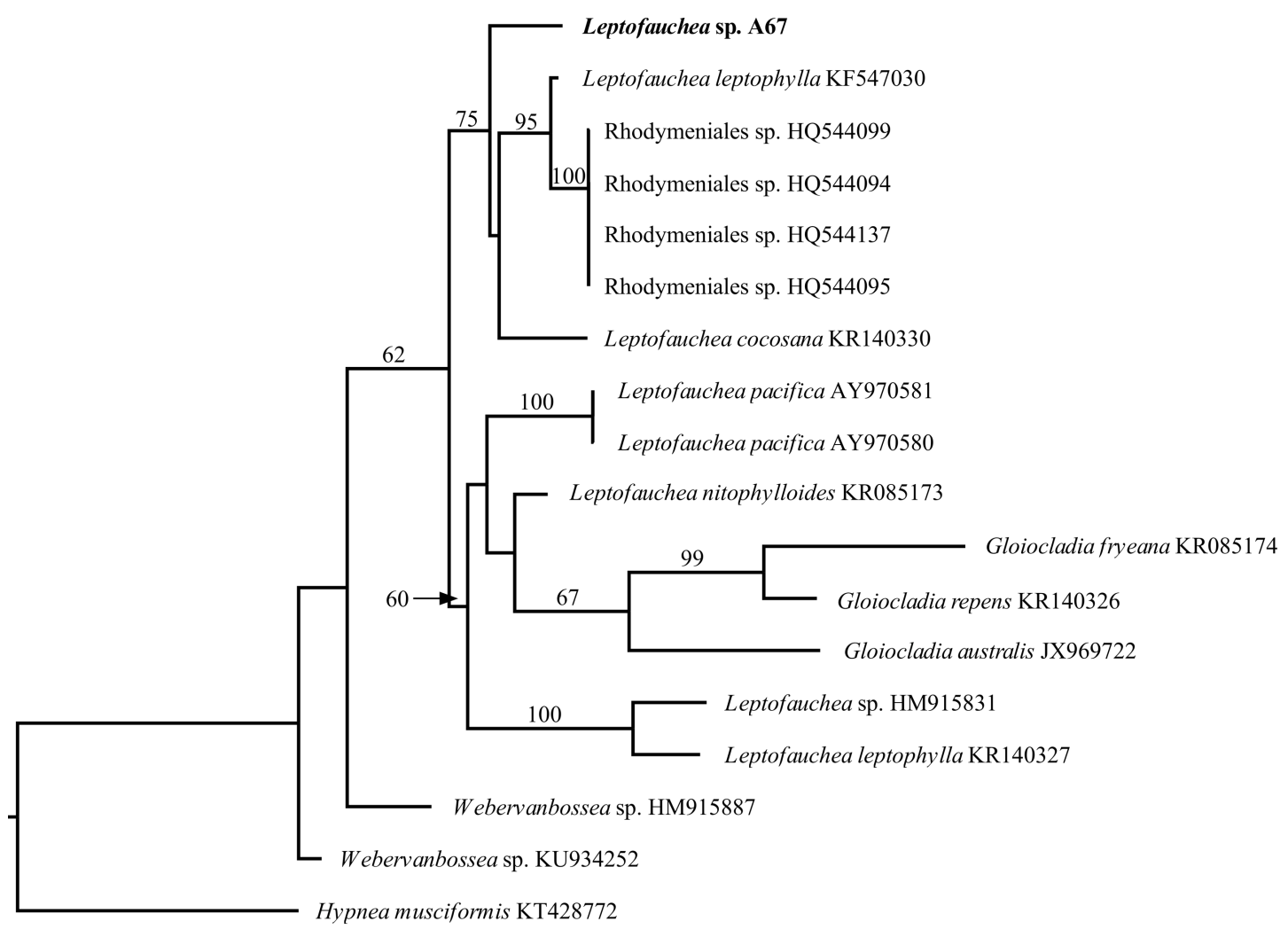

Figure 15. Maximum-likelihood tree of Leptofauchea spp. using cox 1 sequences. Sample A67 shown. Hypnea musciformis (Wulfen) J.V.Lamouroux (KT428772) was used as the outgroup. Only bootstrap support values $>50$ displayed. Scale bar $=0.3$ substitutions per site.

\section{Halopeltis sp.}

Sample A4 (Fig. 16) was dark red flattened thallus, had a constricted base on some branches, the branches overlap forming a matted clump. Branch tips are mostly rounded. Overall, the live specimen was a matted flat thallus with irregular overlapping branches.

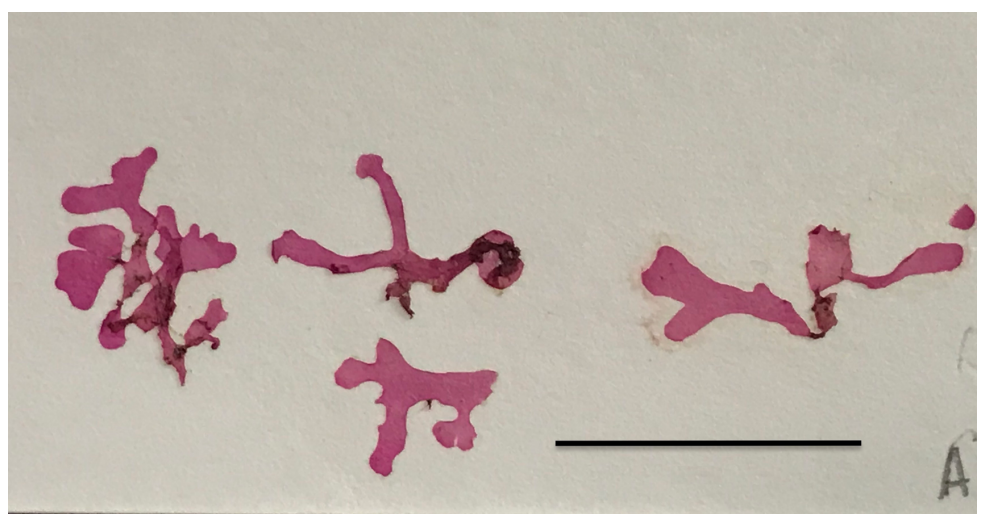

Figure 16. Sample A4, Halopeltis sp., herbarium. Scale bar $=2 \mathrm{~cm}$. 
Sample A4 is within a clade containing Halopeltis willisii Freshwater and Saunders, Halopeltis sp. (EF101939) and Halopeltis adnata G.W.Saunders and C.W.Schneider, with moderate bootstrap support (87\%)(Fig. 17). Aligned sequences show 9.24\% pairwise difference between sample A4 and Halopeltis willisii (HM915686) its closest Genbank sequence and top Blast hit. I designated sample A4 as Halopeltis sp.

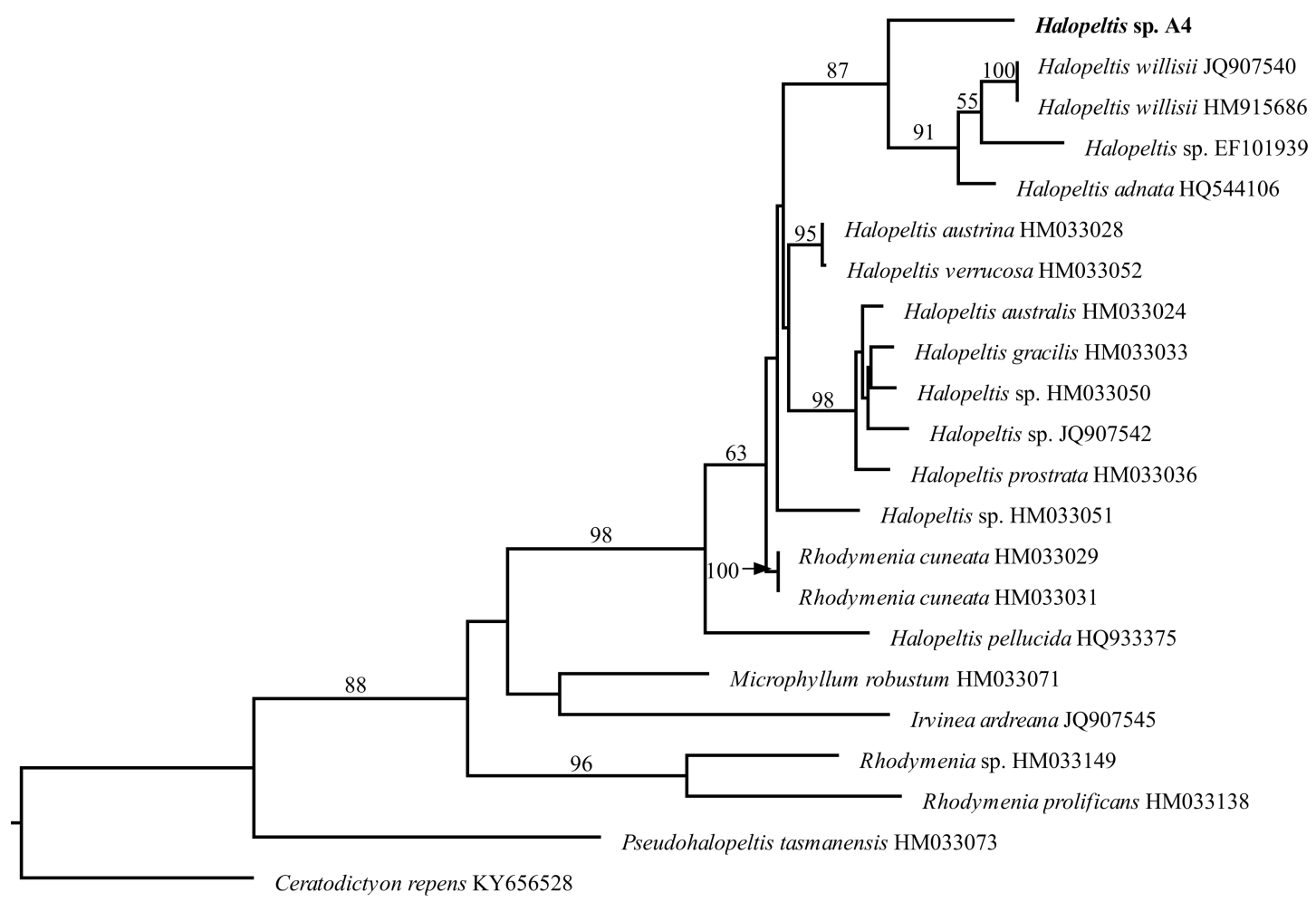

Figure 17. Maximum-likelihood tree of Halopeltis sp. using cox 1 sequences. Sample A4 shown. Ceratodictyon repens (Kützing) R.E.Norris (KY656528) was used as the outgroup. Only bootstrap support values $>50$ displayed. Scale bar $=0.3$ substitutions per site.

Lomentariaceae

Sample A99 (Fig. 18A) had a flattened irregularly branched thallus and a prostrate growth form. Pigmentation was dark reddish brown. Samples A105, A106 (Fig. 18B, C) had subcylindrical irregularly branched thalli that formed a tangled mat-like growth on 
the substrate. The branch tips were rounded and dark-red. Specimens had a single holdfast.

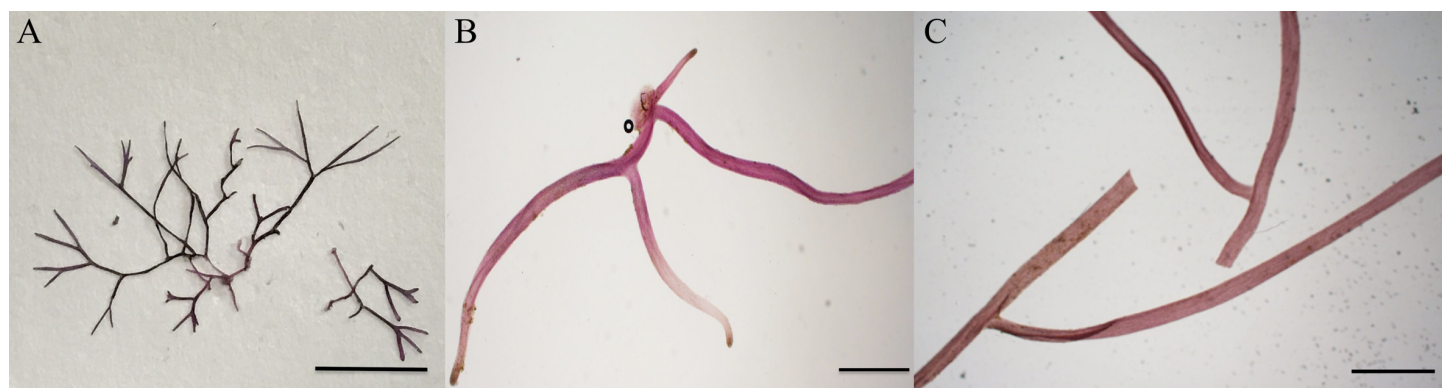

Figure 18. Examples of Gelidiopsis sp. and Ceratodictyon repens herbarium and photomicrographs; $\mathrm{A}=\mathrm{A} 99$, Ceratodictyon repens scale bar $=2 \mathrm{~cm}, \mathrm{~B}=\mathrm{A} 105$, Gelidiopsis sp. Scale bar $=1 \mathrm{~mm}, \mathrm{C}=\mathrm{A} 106$, Gelidiopsis sp. Scale bar $=1 \mathrm{~mm}$.

Sample A99 had the highest Blast hit to Ceratodictyon repens (Kützing) R.E.Norris (KY656528), and is within a clade containing Ceratodictyin repens with high bootstrap support (97\%) (Fig. 19). Sample A99 is $0.65 \%$ different to the closest Genbank sequence, Ceratodictyon repens (KY656528) from Chiriqui, Panama. I designated sample A99 as Ceratodictyon repens. 


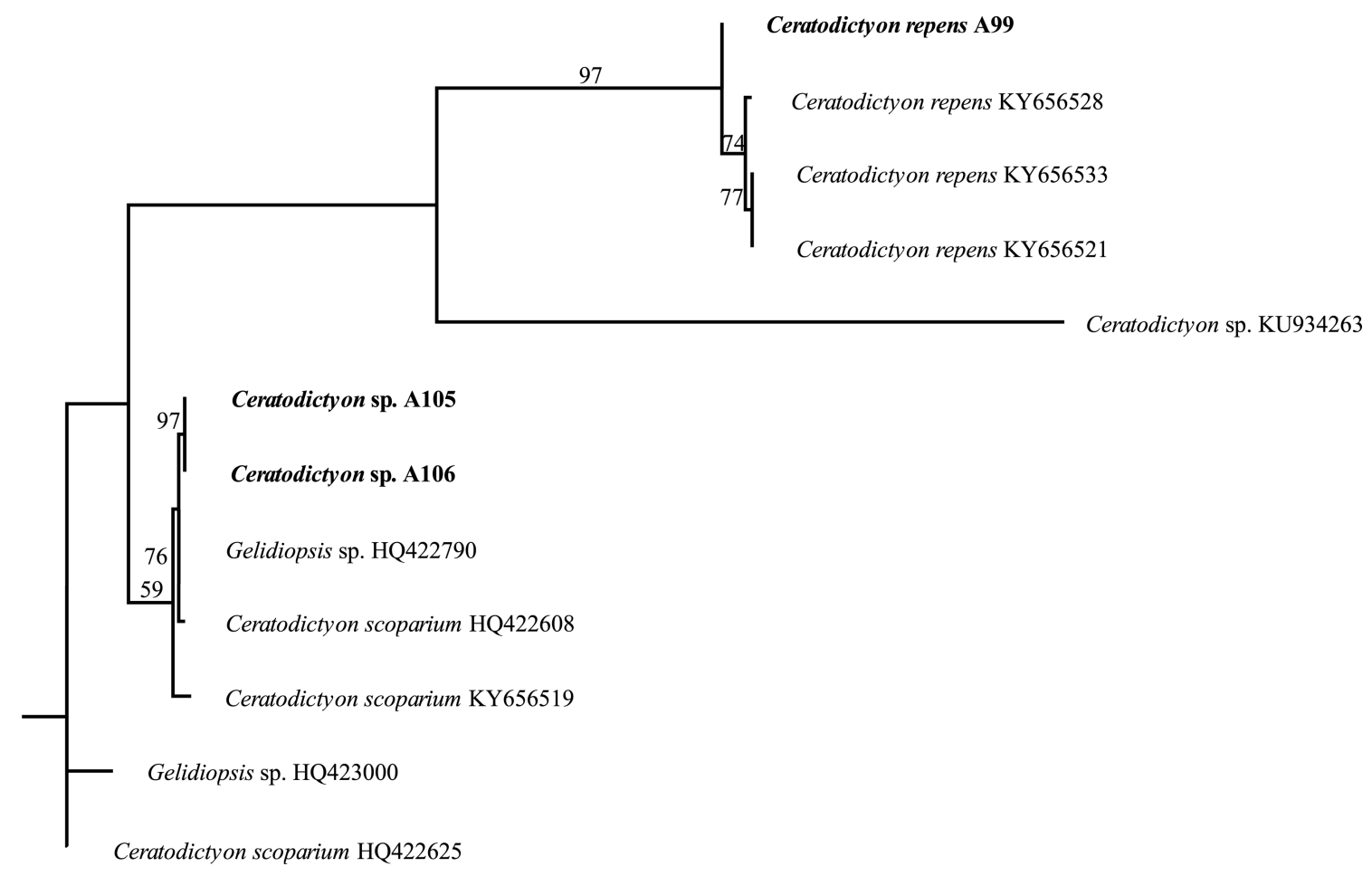

Figure 19. Maximum-likelihood tree of Ceratodictyon spp. and Gelidiopsis spp. using cox1 sequences. Samples A99, A105 and A106 shown. Halopeltis australis (J.Agardh) G.W.Saunders (HM033024) was used as the outgroup and was removed for clarity. Only bootstrap support values $>50$ displayed. Scale bar $=0.3$ substitutions per site.

Specimens A105 and A106 were identical and grouped with high bootstrap support (97\%). Specimens A105 and A106 are within a clade containing Gelidiopsis sp. (HQ422790), and Ceratodictyon scoparium (Montagne and Millardet) R.E.Norris (HQ422608, KY656519). Both samples A105 and A106 have 0.16\% pairwise difference in cox1 to Gelidiopsis sp. (HQ422790), their top Blast hit. As Gelidiopsis sp., and Ceratodictyon sp. are synonymized (Schneider and Whynne 2007). I designated both samples A105 and A106 as Ceratodictyon sp. the same species as Gelidiopsis sp. (HQ422790).

\section{Lomentaria sp.}

Sample A2 (Fig. 20A) was dark red with short, curved branches, frequent indeterminate branching, and the base of each branch had a very slight constriction (Fig. 
22B). The branch tips were rounded (Fig. 20B, C). The specimens are hollow in cross section with a single layer of cortical cells, and one layer of small oval medullary cells (not shown).

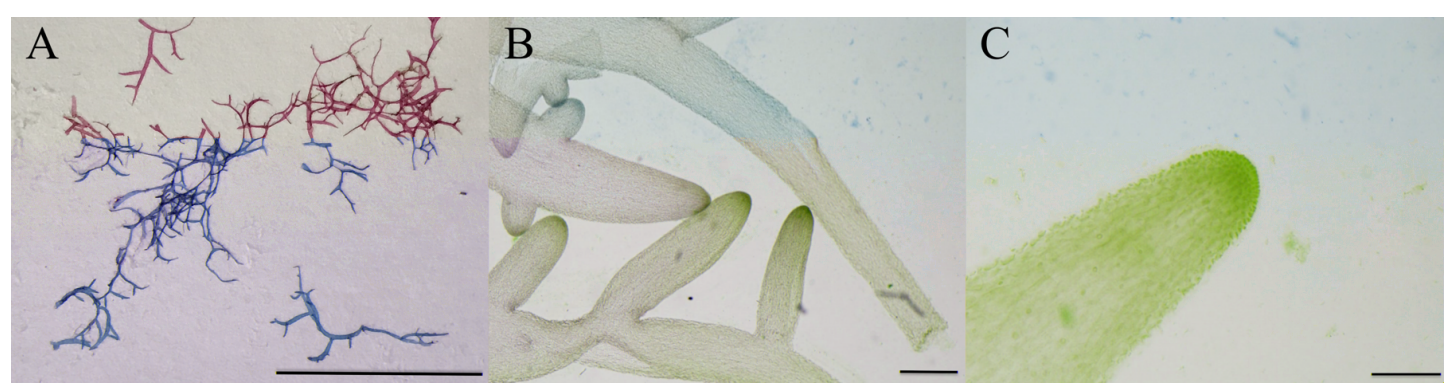

Figure 20. Examples of Lomentaria sp. A2, herbarium and photomicrographs; $\mathrm{A}=$ herbarium sample, scale bar $=2 \mathrm{~cm}, \mathrm{~B}=$ shows branching and slight constrictions, stained with aniline blue, scale bar $=400 \mu \mathrm{m}, \mathrm{C}=$ branch tip, stained with aniline blue, scale bar $=100 \mu \mathrm{m}$.

Sample A2 is sister to Lomentaria hakodatensis Yendo (HQ422881) but with low bootstrap support (50\%) (Fig. 21). There is a clade containing Lomentaria divaricata (now Hooperia divaricata Durant) M.J.Whynne (Whynne et. al. 2019) (KU941949) and the above two sequences with high support bootstrap (87\%). Sample A2 is $14.12 \%$ different in cox 1 to Lomentaria hakodatensis (HQ422881). A2 is $13.4 \%$ different in cox 1 to Lomentaria divaricata (KU941949) from Canada, its closest pairwise sequence and top Blast hit. I designated sample A2 as Lomentaria sp. 


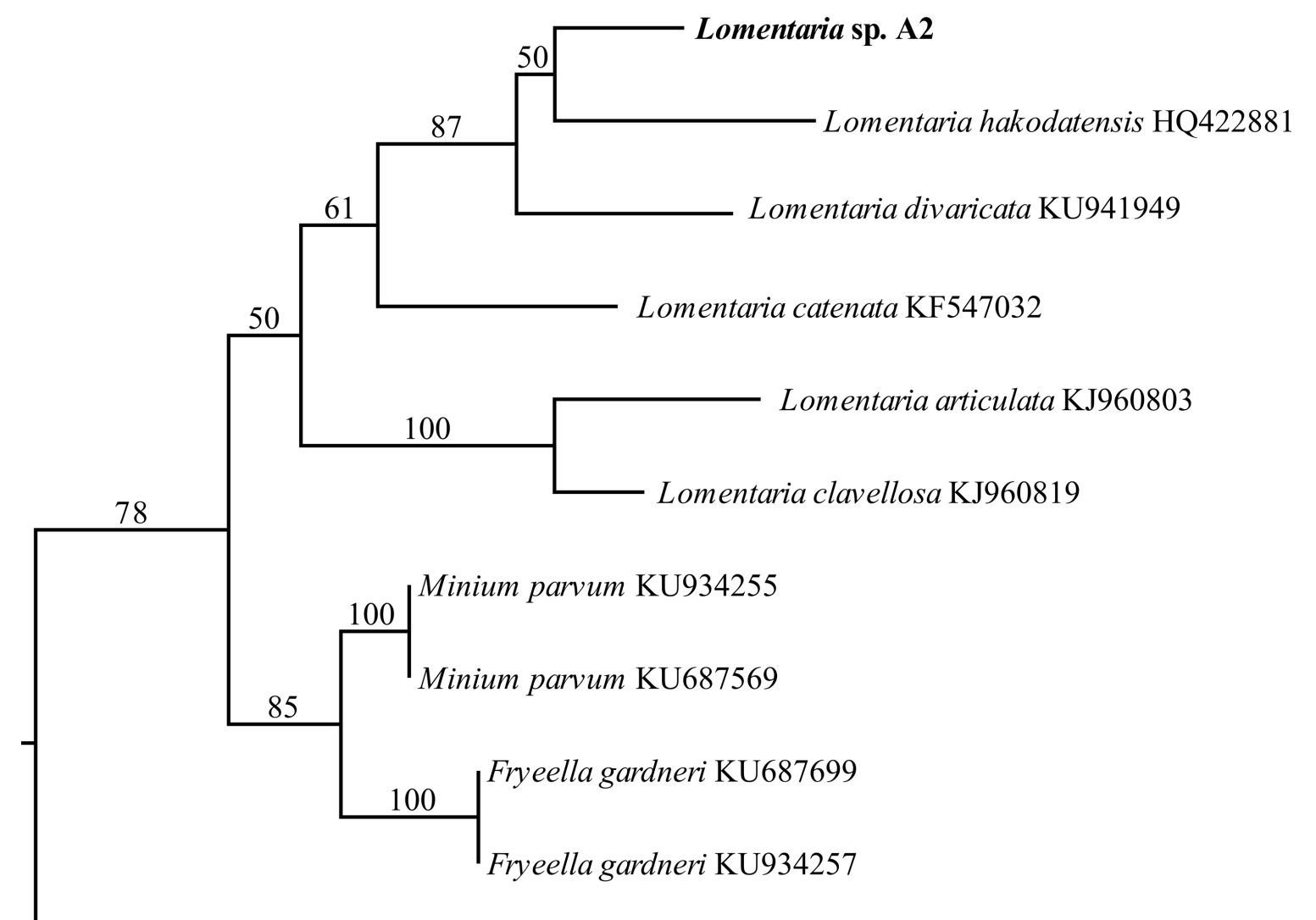

Sonderopelta sp. 1capensis JX969710

Figure 21. Maximum-likelihood tree of some of the Lomentariaceae using cox 1 sequences. Sample A2 shown. Sonderopelta sp. (JX969710) was used as the outgroup. Only bootstrap support values $>50$ displayed. Scale bar $=0.3$ substitutions per site.

\section{Chamaebotrys spp.}

Samples (Fig. 22A-C) were small, $<1 \mathrm{~cm}$, and were composed of rounded fleshy red vesicles with flattened upper surface. Samples were unbranched, except for A64 (Fig. 22C). A small holdfast was present and attached to the aragonite substrate, vesicles contained mucilage. 


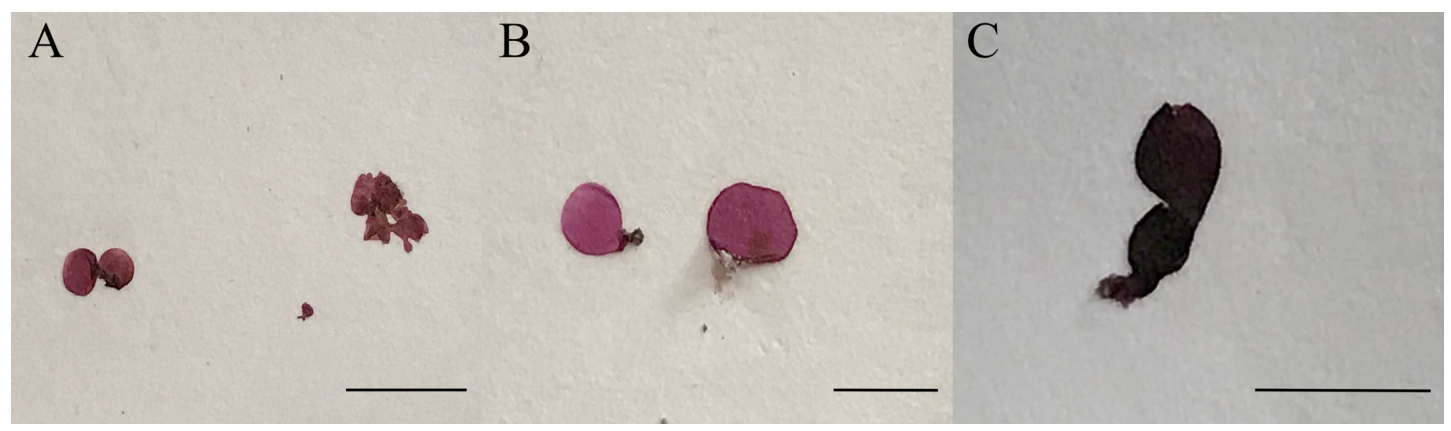

Figure 22. Examples of Chamaebotrys spp. Herbariums; A = A9, B = A23, C = A64. Scale bars $=1 \mathrm{~cm}$

Sample A23 is sister to Chamaebotrys boergesenii T.Tanaka (KU726729) based on $r b c \mathrm{~L}$ sequence data, but with low bootstrap support $(<50 \%)$ (Fig. 23). Sample A23 has a pairwise distance of $13.56 \%$ in $r b c \mathrm{~L}$ to its sister Chamaebotrys boergesenii (Weber Bosse) (KU726729) from Western Australia. The sample, however, has 10.7\% pairwise difference to its top Blast hit Chrysymenia brownii (KU726719). Idesignated sample A23 as Chamaebotrys sp1.

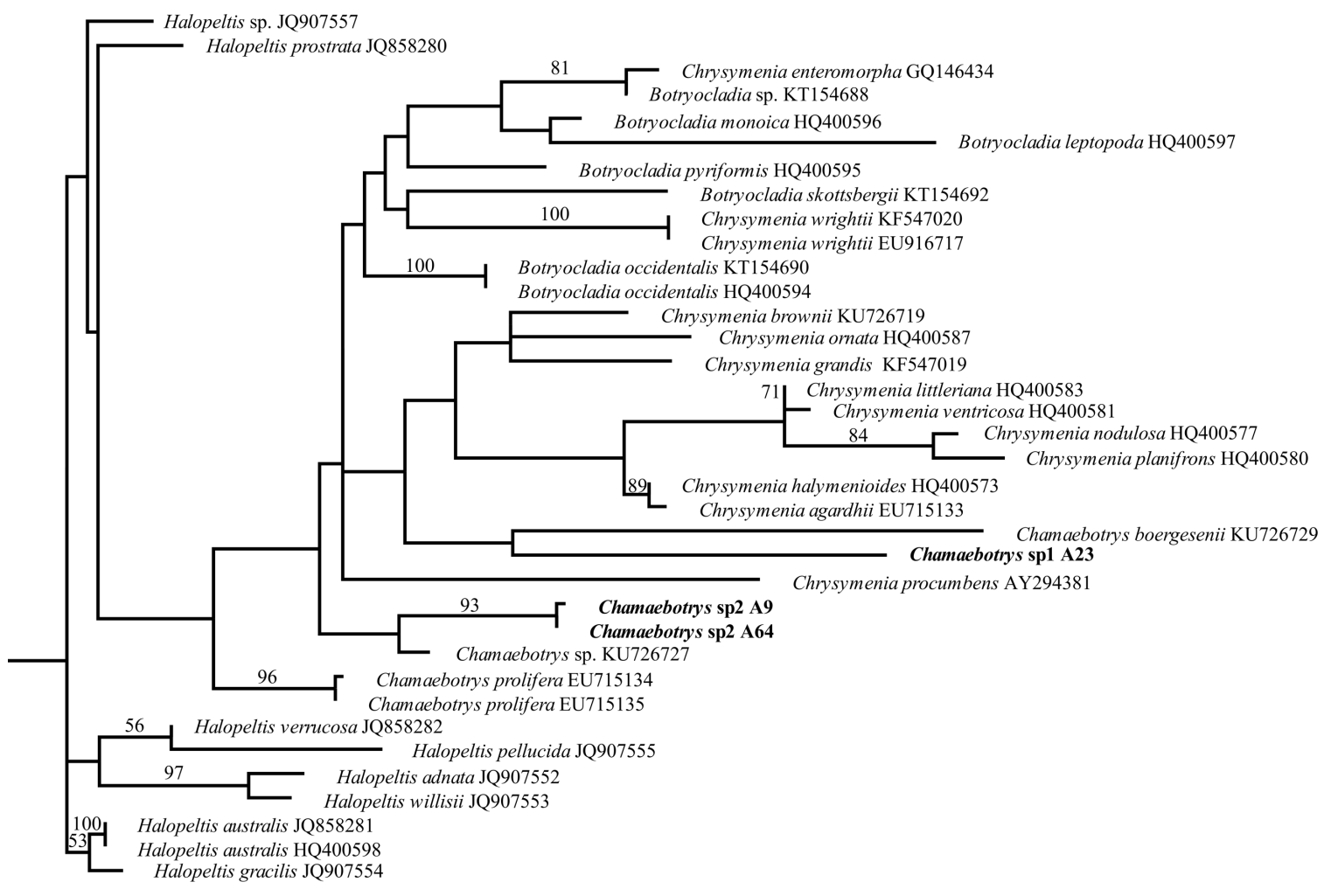

Figure 23. Maximum-likelihood tree for Chamaebotrys spp. using $r b c \mathrm{~L}$ sequences. Samples A9, A23, A64 shown. Hypnea borgesenii (AF385634) was used as the outgroup and was removed for clarity. Only bootstrap values $>50$ displayed. Scale bar $=0.2$ substitutions per site. 
Samples A9 and A64 grouped together with high support bootstrap (93\%).

Aligned sequences show $0.31 \%$ difference between samples A9 and A64, they are within a clade containing their top Blast hit Chamaebotrys sp. (KU726727) with low bootstrap support. Sample A9 has $4.66 \%$ pairwise difference in $r b c \mathrm{~L}$ to Chamaebotrys sp. (KU726727) from New South Wales, Australia and A64 has 4.62\% pairwise difference to Chamaebotrys sp. (KU726727). I designated samples A9 and A64 as Chamaebotrys sp2.

Amphiroa sp.

Sample A33 (Fig. 24) was a geniculate coralline alga with thin heavily calcified branches with rounded branch tips. Branches were $1.5-4 \mathrm{~mm}$ in length and $250 \mu \mathrm{m}$ in diameter. The specimen when collected was pink with pale branch tips.

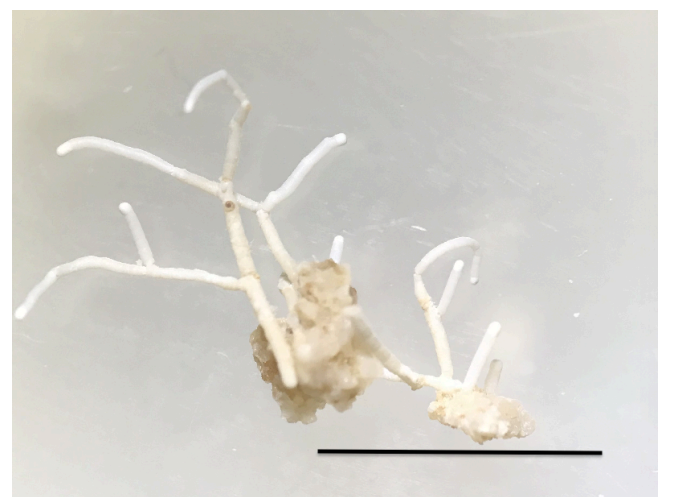

Figure 24. Sample Amphiroa sp. A33, herbarium. Scale bar $=0.5 \mathrm{~cm}$.

Sample A33 is within a clade, based on cox 1 sequence data, containing uncultured Corallinales (GQ917303, GQ917507) and Amphiroa valonioides Yendo (HQ422698) and Amphiroa bowerbankii (LC071730) without support bootstrap (<50\%)(Fig. 25). Aligned sequences show that $\mathrm{A} 33$ has $9.95 \%$ pairwise difference in cox 1 to the top Blast hit and closest Genbank sequence Amphiroa anceps A.Mann (LC071723) from Eastern Cape, South Africa and A. anceps (LC071724, LC071725). I designated sample A33 as Amphiroa sp. 


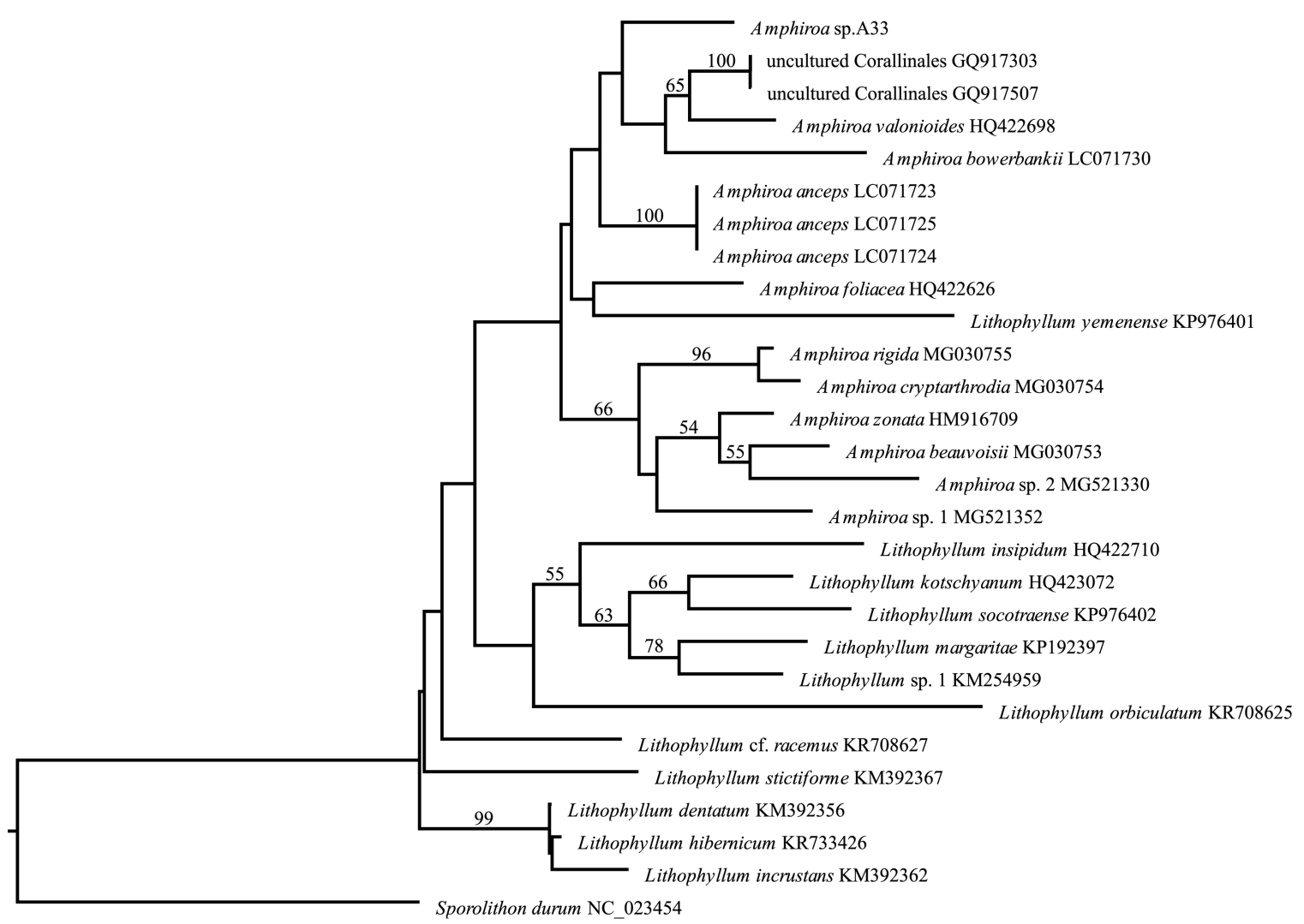

Figure 25. Maximum-likelihood tree of Amphiroa spp. using cox 1 sequences. Sample A33 shown. Sporolithon durum (NC 023454) was used as the outgroup. Only bootstrap support values $>50$ displayed. Scale bar shows 0.5 substitutions per site. 


\subsection{Identification of Green algae}

Ulva ohnoi

One sample of Ulva ohnoi M.Hiraoka and S.Shimada was found free living in a holding tank at a pet shop in Lower Hutt; the sample was a ruffled light-green thallus. Preservation in ethanol resulted in loss of pigment (Fig. 26).

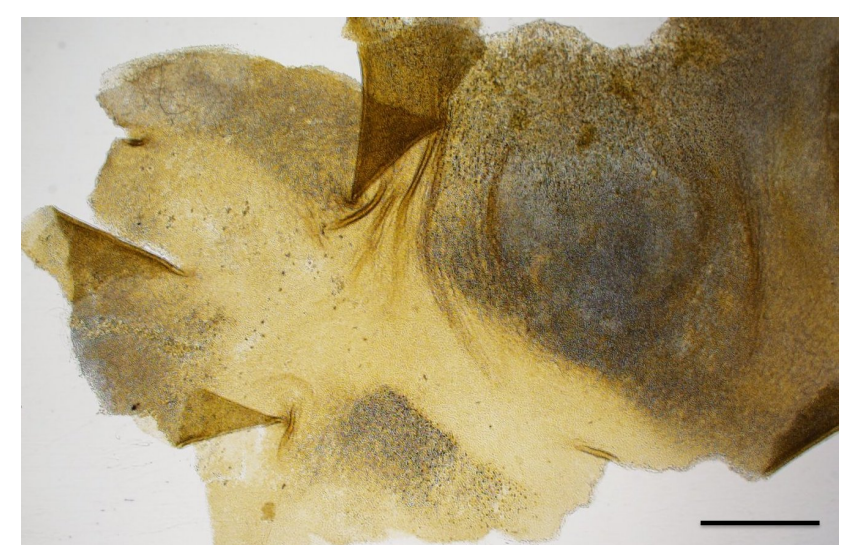

Figure 26. Sample Ulva ohnoi A42, photomicrograph. Scale bar $=1 \mathrm{~mm}$.

Specimen A42 is within a clade, based on tufA sequence data, containing Ulva ohnoi, Ulva beytensis. M.Hiraoka and S.Shimada Ulva reticulata Forsskål and Ulva taeniata Setchell with moderate bootstrap support (81\%)(Fig. 27). Aligned sequences showed that A42 is identical in tufA to the top Blast hit Ulva ohnoi (KF195523) from Australia and U. ohnoi (MF614793) from Gabes, Tunisia. I designated specimen A42 as Ulva ohnoi. 


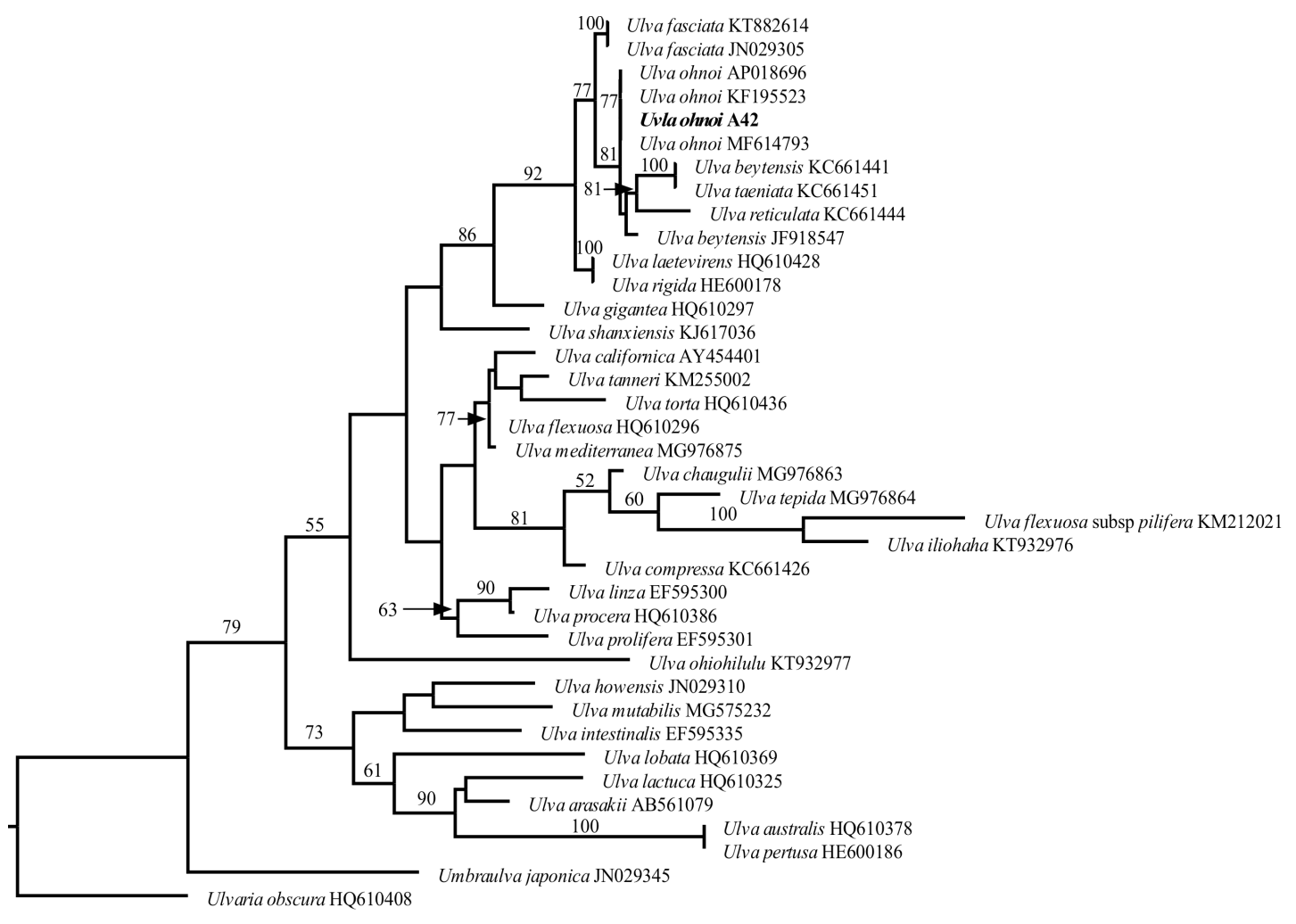

Figure 27. Maximum-likelihood tree of Ulva spp. using tufA gene sequences. Specimen A42 shown. Ulvaria obscura (Kützing) Gayral ex Bliding (HQ61048) was used as the outgroup. Only bootstrap support values $>50$ displayed. Scale bar $=0.03$ substitutions per site.

\section{Chaetomorpha spp.}

Three samples identified as Chaetomorpha sp. and Lurbica sp. were found during this study. Sample A80 (Fig. 28A) is formed of large sized cells, $400 \mu \mathrm{m}$ in diameter and $600 \mu \mathrm{m}-1 \mathrm{~mm}$ in length, filaments are dark green and are tangled in rounded balls. The sample was unattached to the substrate. Specimen A82 (Fig. 30B) has thin unbranched upright filaments up to $6 \mathrm{~cm}$ long and is attached to substrate. 


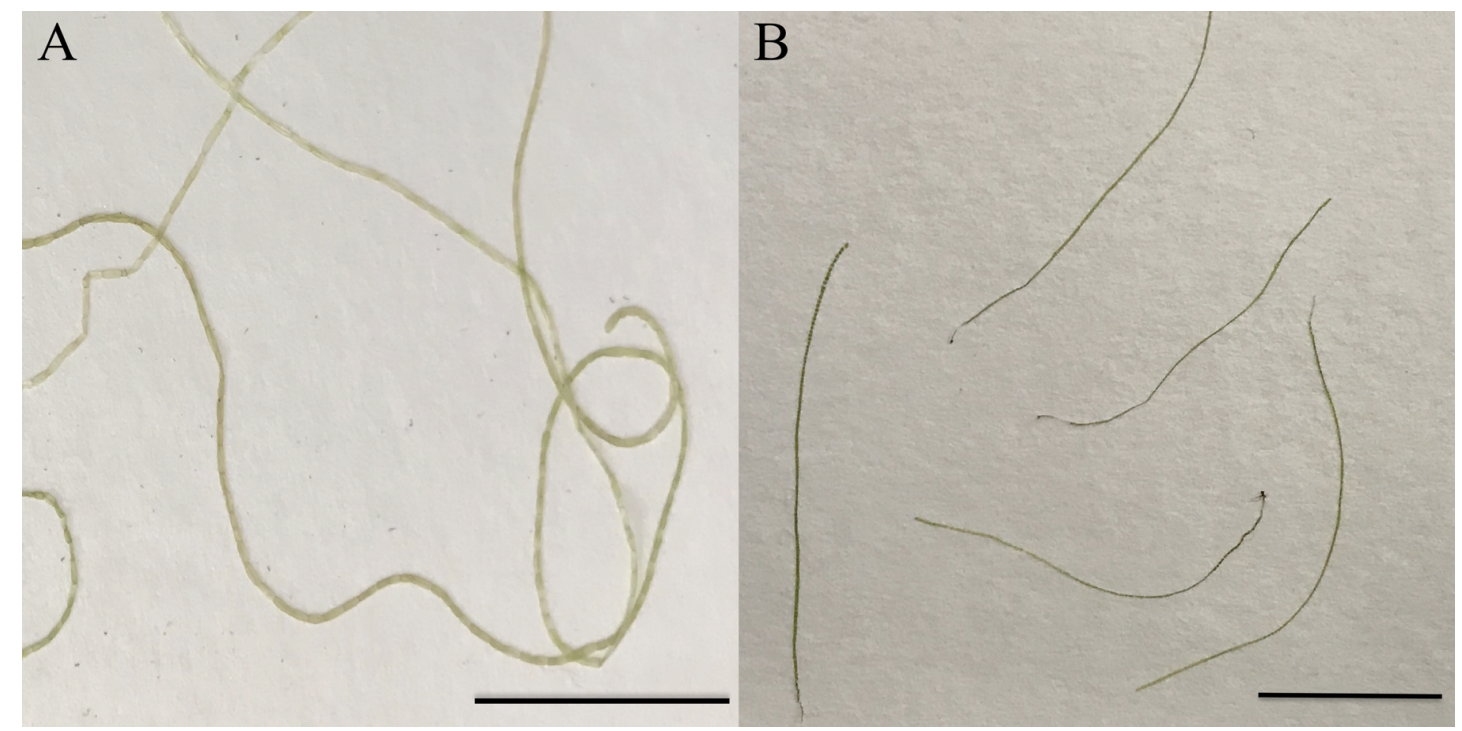

Figure 28. Samples of Chaetomorpha spp. Herbarium; A = Chaetomorpha spiralis A80, scale bar $=2 \mathrm{~cm}, \mathrm{~B}=$ Chaetomorpha $\mathrm{sp}$. A 82 Scale bar $=2 \mathrm{~cm}$.

Sample A80 is within a clade, based on LSU sequences, containing Chaetomorpha sp. (LT607220) Chaetomorpha cf. inflata Kützing (LT607071), C. vieillardii (LT607222, LT607223), Chaetomorpha spiralis Okamura (LT607221), and sample A112 (Fig. 29) with high support (100\%). Both A80 and A112 are within a larger clade with high bootstrap support 100\% that also contains Chaetomorpha basiretrorsa (LT607219). A80 has 0.4\% difference in LSU to Chaetomorpha spiralis (LT607221), its closest pairwise sequence and top Blast hit. A80 has $0.5 \%$ pairwise difference to $C$. vieillardii (LT607222). I designated sample A80 as Chaetomorpha vieillardii. A112 has 100\% identity to the top Blast hit Chaetomorpha spiralis (LT607221) from Mombasa, Kenya and a sample of Chaetomorpha vieillardii (LT607222) from Zanzibar, Tanzania. I designated sample A112 as Chaetomorpha vieillardii. 


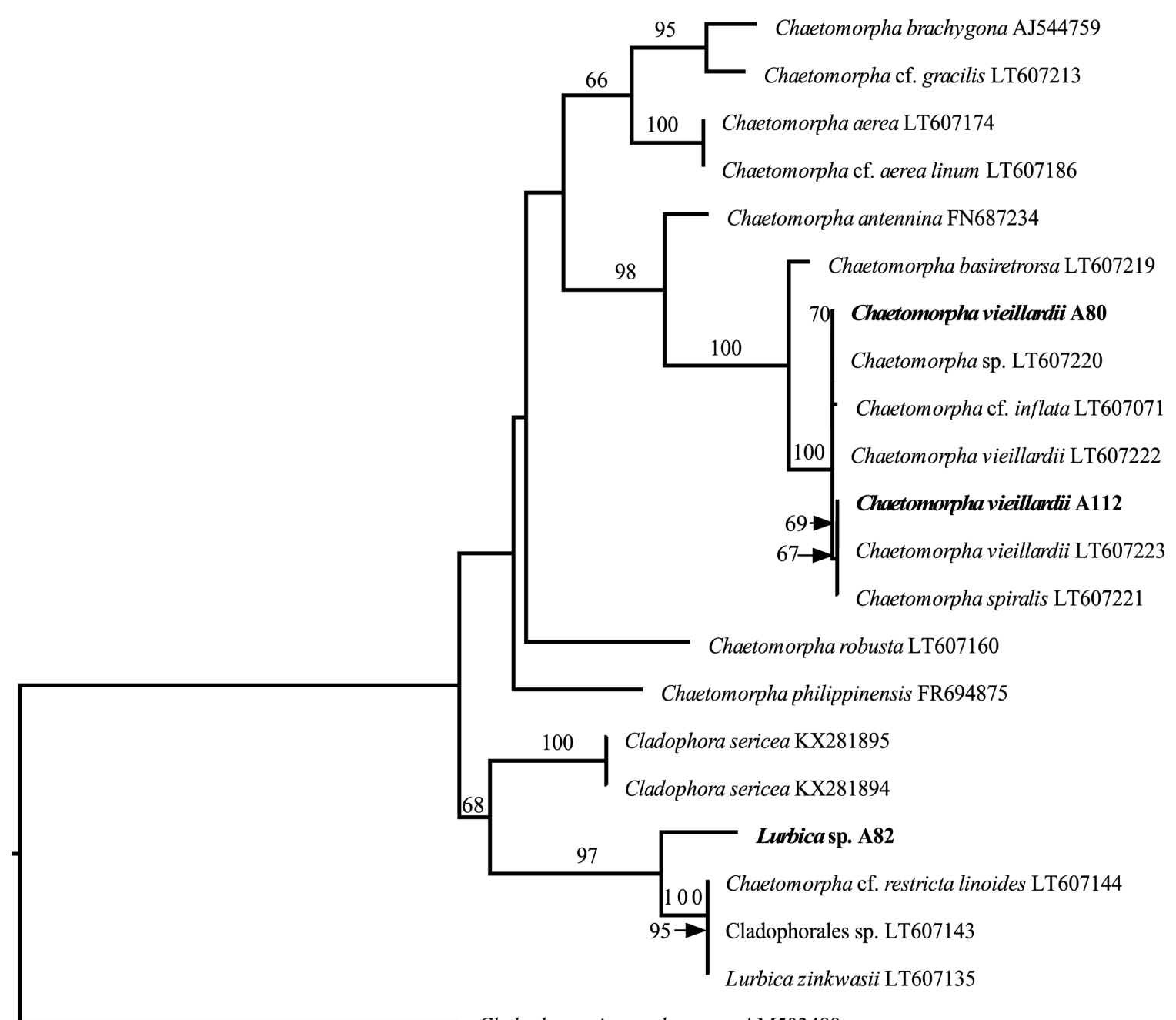

Cladophoropsis membranacea AM503489

Figure 29. Maximum-likelihood tree of some Cladophorales using LSU gene sequences. Samples A80, A82, A112 shown. Cladophoropsis membranacea (AM503489) was used as the outgroup taxa. Only bootstrap support values $>50$ displayed. Scale bar $=0.04$ substitutions per site.

Sample A82 is within a clade containing Chaetomorpha $\mathrm{cf}$. restricta (Suhr) Kützing, Cladophorales sp. and Lurbica zinkwasii Boedeker with high support bootstrap (97\%). The aligned sequences show that A82 has 3.37\% pairwise difference in LSU to all samples in the clade including the top Blast hit Chaetomorpha cf. restricta (LT607144) I designated sample A82 as Lurbica sp. 


\section{Cladophora spp.}

Various Cladophora and samples were found on imported coral rocks sample. A19 (Fig. $30 \mathrm{~A}$ ) is branched with large cells $0.4-1.5 \mathrm{~mm}$ in width and $1-2 \mathrm{~mm}$ in length whole specimen had a fan shape. Sample A34 (Fig. 30B) is branched with long narrow cells 0.35-1mm in length. Sample A38 (Fig. 30C) has cells 40-60 $\mu \mathrm{m}$ in diameter and 95$130 \mu \mathrm{m}$ in length. Sample A113 (Fig. 30D) is an unbranched filament with cells $60 \mu \mathrm{m}$ in width and 50-75 $\mu \mathrm{m}$ in length. Micrographs of samples of A39, A115 and A114 were included in (Fig. S5).

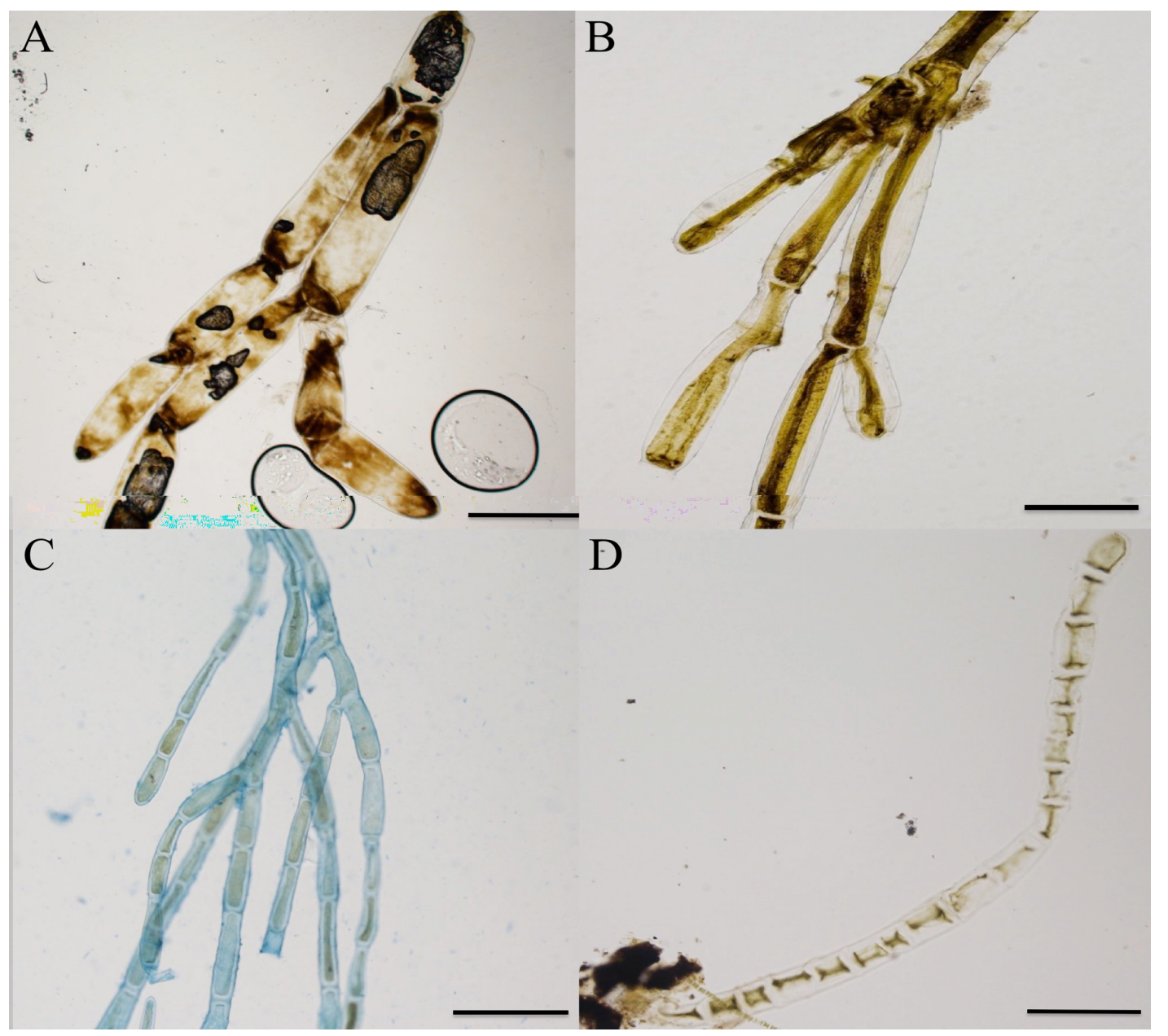

Figure 30. Examples of Cladophora spp. Herbariums and photomicrographs; $A=A 19$ scale bar $=1 \mathrm{~mm}, \mathrm{~B}=\mathrm{A} 34$ scale $\mathrm{bar}=400 \mu \mathrm{m}, \mathrm{C}=\mathrm{A} 38$ stained with aniline blue, scale bar $=200 \mu \mathrm{m}, \mathrm{D}=\mathrm{A} 113$, scale $200 \mu \mathrm{m}$. 
Samples A19 and A39 are in a clade, based on LSU sequences with moderate support bootstrap (77\%)(Fig. 31), and showed only $0.13 \%$ sequence difference to each other. They grouped with Lychaete dotyana (W.J.Gilbert) M.J.Wynne with high support bootstrap (100\%). Both A19 and A39 have high similarity to the closest Genbank sequence Lychaete dotyana (LT904846) from Reunion Island, Indian Ocean. A19 has $0.47 \%$ difference and A39 has $0.35 \%$ difference with L. dotyana (LT904846) their closest pairwise sequence. I designated samples A19 and A39 as Lychaete dotyana.

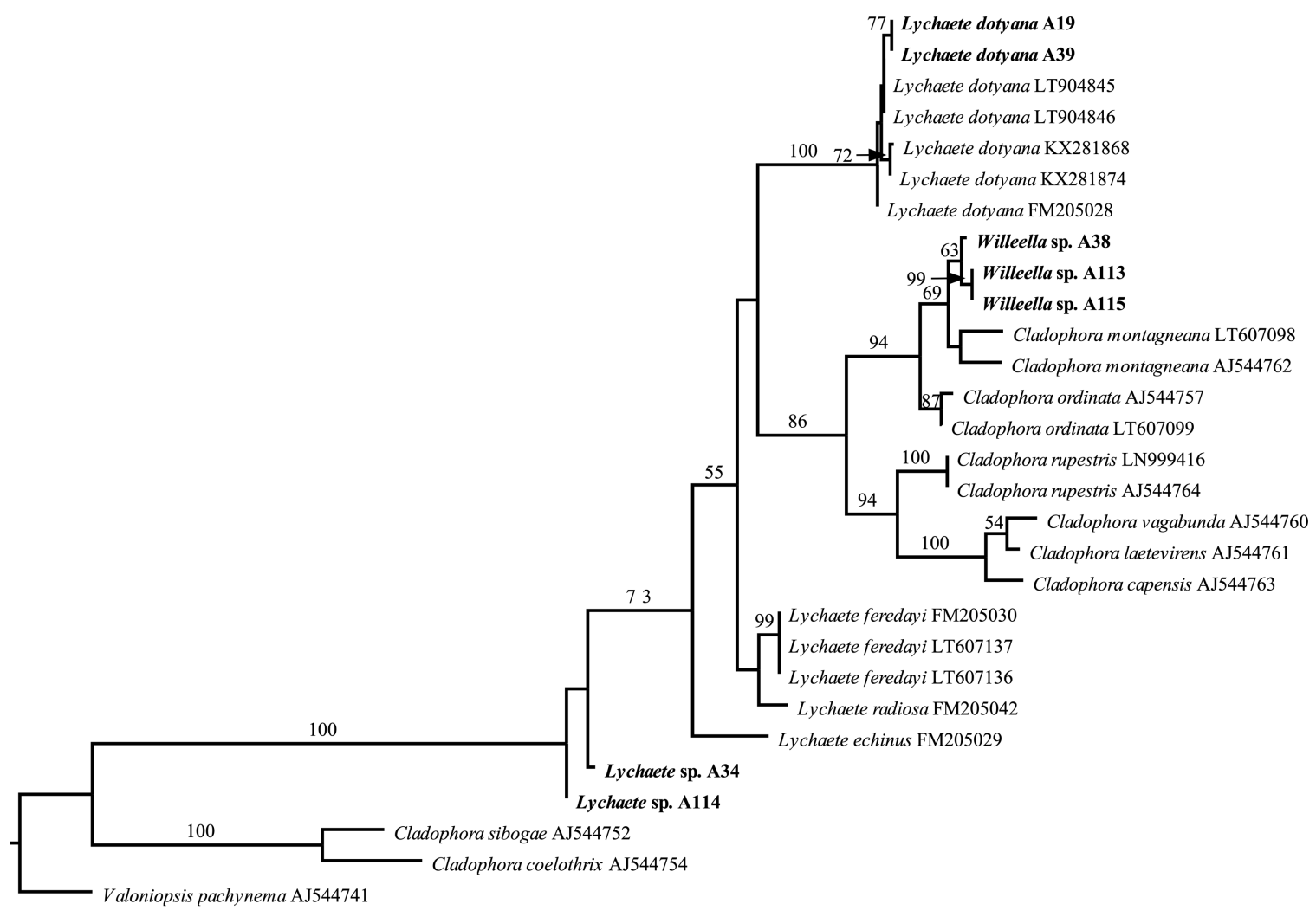

Figure 31. Maximum-likelihood tree of some Cladophorales using LSU gene sequences. Samples A19, A38, A39, A113, A114, A115 shown. Valoniopsis pachynema (G.Martens) Børgeson (AJ544741) was used as the outgroup. Only bootstrap support values $>50$ displayed. Scale bar $=0.05$ substitutions per site.

Both samples A113 and A115 had identical sequences of LSU and formed a well supported group (99\%). The samples grouped with sample A38 but with lower bootstrap support (63\%). These samples were in a clade with Cladophora montagneana Kützing (now Willeella brachyclados (Montagne) M.J.Wynne) with low bootstrap support (69\%). 
Samples A38, A113 and A115 all have 2.8\% difference in LSU to their closest Genbank sequence and top Blast hit, Cladophora montagneana (LT607098) from Western Australia. I designated samples A38, A113 and A115 as Willeella sp.

Samples A114 and A34 are sister to many of the species in the data set. A114 and A34 have $1.5 \%$ pairwise difference to each other, and are likely the same species. A114 has $6.62 \%$ pairwise difference in LSU to its top Blast hit, Lychaete feredayi (Harvey) M.J.Wynne (FM205030) from Kaikoura, New Zealand. I designated sample A114 as Lychaete sp. Specimen A34 has 6.32\% difference in LSU to Lychaete feredayi (FM205030) its closest pairwise sequence and top Blast hit. I designated sample A34 as Lychaete sp.

\section{Cladophoropsis sp.}

Samples A36 and A43 (Fig. 32A-C) are tufts of rigid branching filaments, mostly 140-160 $\mu \mathrm{m}$ in diameter and up to $4 \mathrm{~cm}$ in length for A36, and up to $300 \mu \mathrm{m}$ for sample A43, arising from a stolon. The stolon has cells of varying sizes up to $400 \mu \mathrm{m}$ in diameter and $450 \mu \mathrm{m}$ in length. Secondary attachment cells (tenaculae) are present on branches, and rhizoids are present on stolons. Live specimen (Fig. 32C) had deep green pigmentation and a shiny appearance. Filament length and diameter is highly variable.

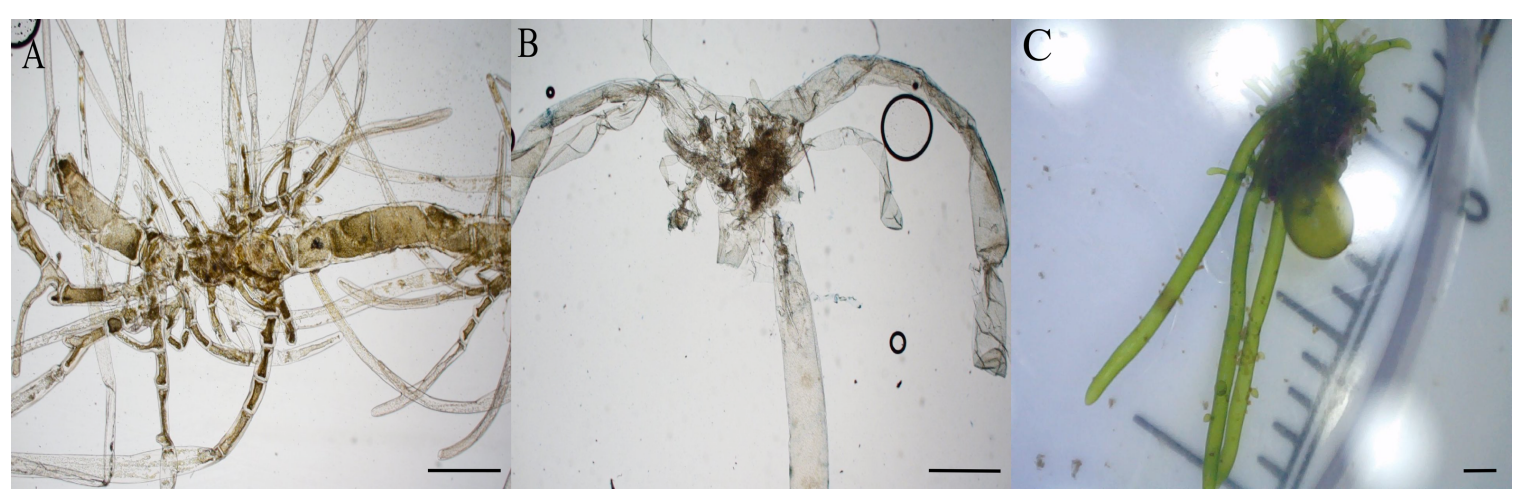

Figure 32. Examples of samples of Cladophoropsis sp., Photomicrographs; $\mathrm{A}=\mathrm{A} 36, \mathrm{~B}=$ $\mathrm{A} 43, \mathrm{C}=\mathrm{A} 36$ live specimen grown in aquaria. Scale bars $=1 \mathrm{~mm}$. 
Specimens A36 and A43 are within a large clade, based on LSU sequence data, containing Cladophoropsis membranacea Hofman Bang ex C.Agardh) Børgesen (AM503489), Cladophoropsis philippinensis W.R.Taylor, Boodlea composita (Harvey), Boodlea montagnei (Harvey ex J.E.Gray) Egerod, Boodlea saimensis Reinbold, Cladophoropsis sp., Phyllodictyon anastomosans (Harvey) Kraft and M.J.Wynne with moderate bootstrap support (74\%) (Fig. 33). Sample A36 has 0.19\% pairwise difference to the top Blast hit, Cladophoropsis membranacea (AM503489), and the following sequences: Cladophoropsis sp. (AM503489), Boodlea siamensis (AM503422), Cladophoropsis philippensis (AM503490), Phyllodictyon anastomosans (AM503520). Sample A43 has $0.14 \%$ pairwise difference in LSU to the top Blast hit Cladophoropsis membranacea (AM503489) and the following sequences: Cladophoropsis sp. (AM503489), Boodlea siamensis (AM503422), Cladophoropsis philippensis (AM503490), Phyllodictyon anastomosans (AM503520). I designated samples A36 and A43 as Cladophoropsis sp. 


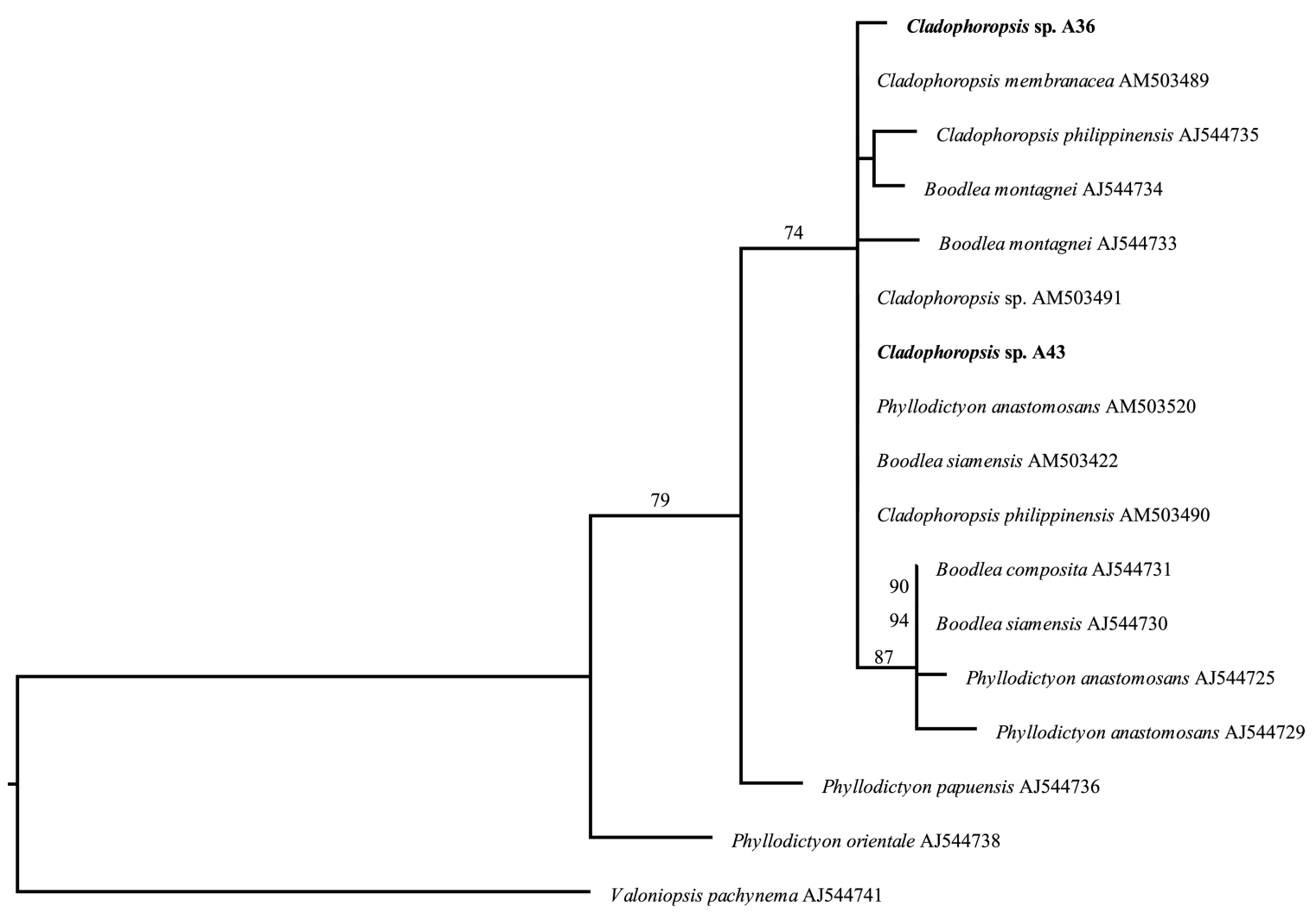

Figure 33. Maximum-likelihood tree of some species within the Siphonocladales using LSU gene sequences. Samples A36 and A43 shown. Valoniopsis pachynema (AJ544741) was chosen as the outgroup. Only bootstrap support $>50$ displayed. Scale bar $=0.008$ substitutions per site

\section{Valonia spp.}

Six samples were found of rigid siphonous vesicles. Some specimens were irregularly branched, attached to the substrate by single holdfast, with green pigmentation and sometimes with a metallic appearance. Samples A27 and A54 (Fig. 34A) were solitary single vesicles. Sample A27 was large, 3cm in diameter. A73, A74, A116 (Fig. 34B, C) were in small clusters, sometimes branched. 


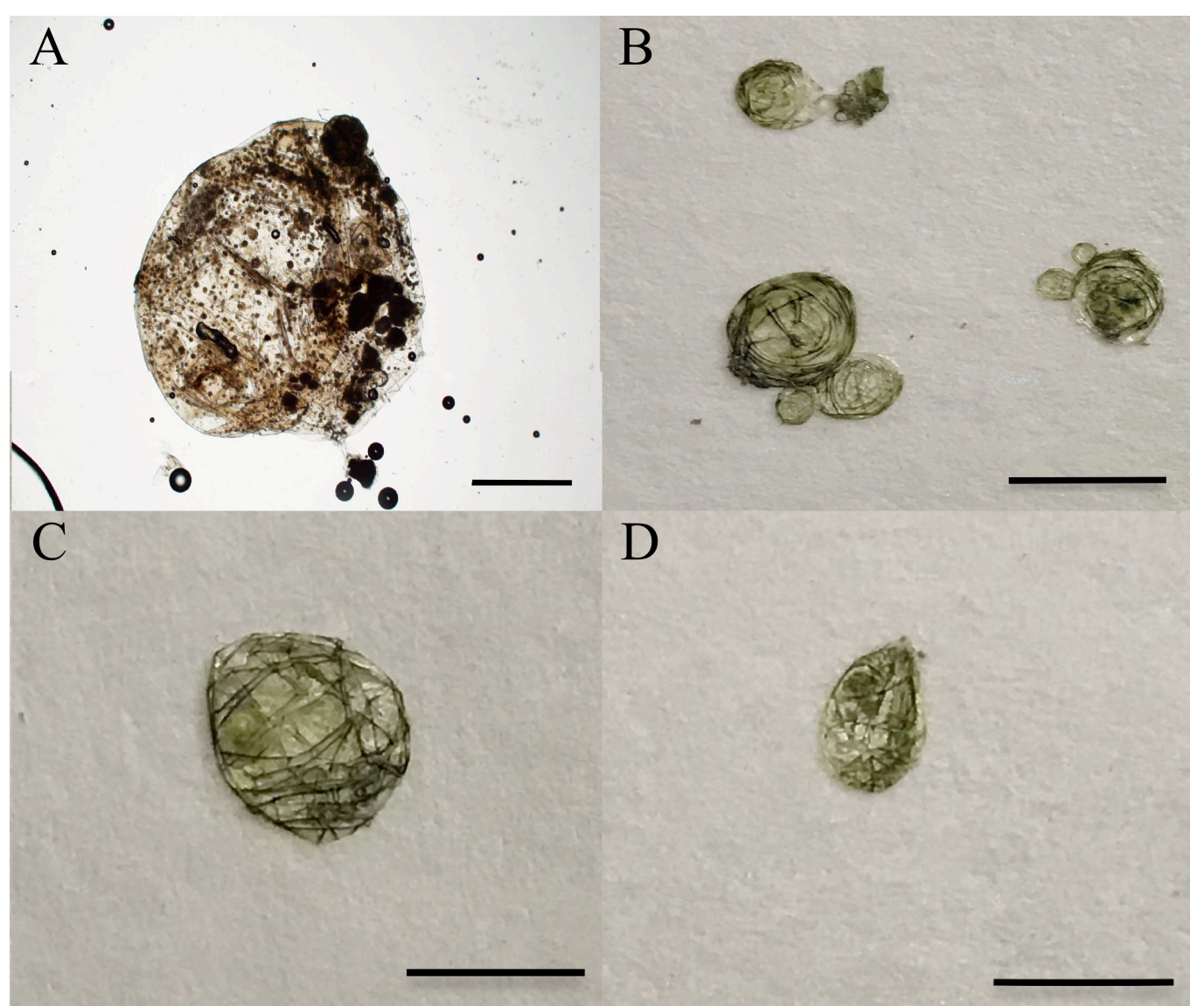

Figure 34. Examples of samples of Valonia spp. Herbarium; A = A54 Valonia ventricosa scale bar $=1 \mathrm{~mm}, \mathrm{~B}=\mathrm{A} 116$ Valonia macrophysa, scale bar $=0.5 \mathrm{~cm}, \mathrm{C}=\mathrm{A} 73$ Valonia macrophysa, scale bar $=0.5 \mathrm{~cm}, \mathrm{D}=\mathrm{A} 75$ Valonia fastigiata, scale bar $=0.5 \mathrm{~cm}$.

Specimens A27 and A54 are within a clade, based on LSU sequence data, containing sequences named Ventricaria ventricosa (J.Agardh) J.L.Olsen and J.A.West (now Valonia ventricosa J.Agardh) with high bootstrap support (99\%)(Fig. 35). Both A27 and A54 have identical sequences to the top Blast hit, $V$. ventricosa (AM503545) from Tahiti. I designated both A27 and A54 as Valonia ventricosa. 


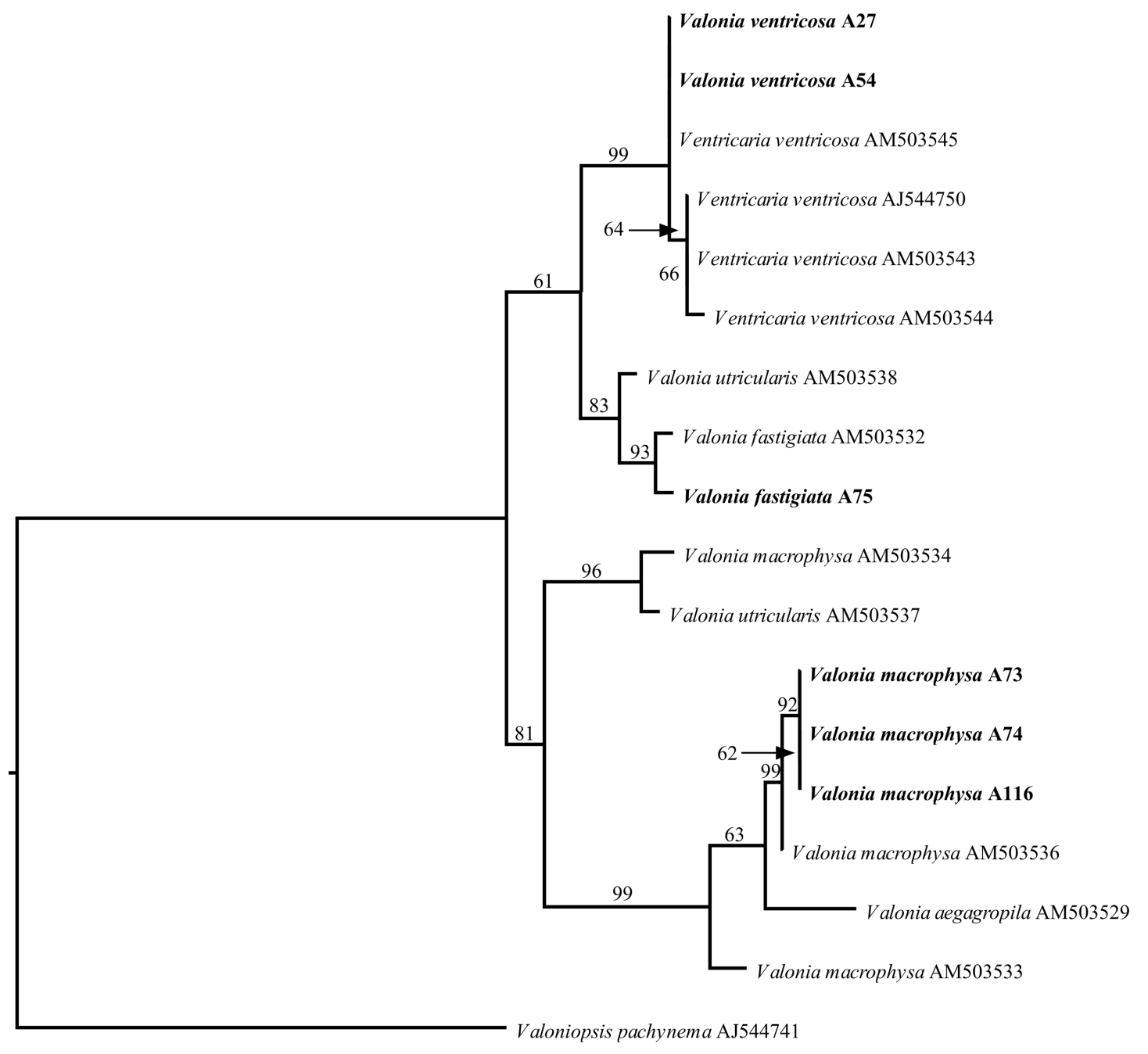

Figure 35. Maximum-likelihood tree of Valonia spp. using LSU gene sequences Samples A27, A54, A73, A74, A75 and A116 shown. Valoniopsis pachynema (AJ44714) was used as the outgroup. Only bootstrap values $>50 \%$ displayed. Scale bar $=0.01$ substitutions per site.

Specimen A75 is sister to Valonia fastigiata Harvey ex J.Agardh (AM503532) its top Blast hit with $93 \%$ bootstrap support, both sequences are in a clade containing Valonia utricularis (Roth) C.Agardh (AM503538) with moderate bootstrap support (83\%). Sample A75 has 1.31\% pairwise difference in LSU to the closest Genbank sequence $V$. fastigiata (AM503532) from Desroches Atoll, Seychelles. I designated A75 as Valonia fastigiata. Specimens A73, A74 and A116 are closely related to each other with high bootstrap support (92\%) and are sister to Valonia macrophysa Kützing (AM503536) with 99\% bootstrap support. Both A74 and A116 have 0.18\% pairwise 
difference to the top Blast hit V. macrophysa (AM503536) from Kwa Zulu Natal, South Africa, whilst A73 has $0.4 \%$ difference to V. macrophysa (AM503536). I designated samples A73, A74 and A116 as Valonia macrophysa.

Bryopsis sp.

Thalli of sample A100 (Fig. 36) form dense soft tufts, up to $4 \mathrm{~cm}$ high, carpeting coral rock and mariculture plugs. Individual plants are like plumules, irregularly branched with a bare basal section of varying lengths. The upper section has distichous branching.

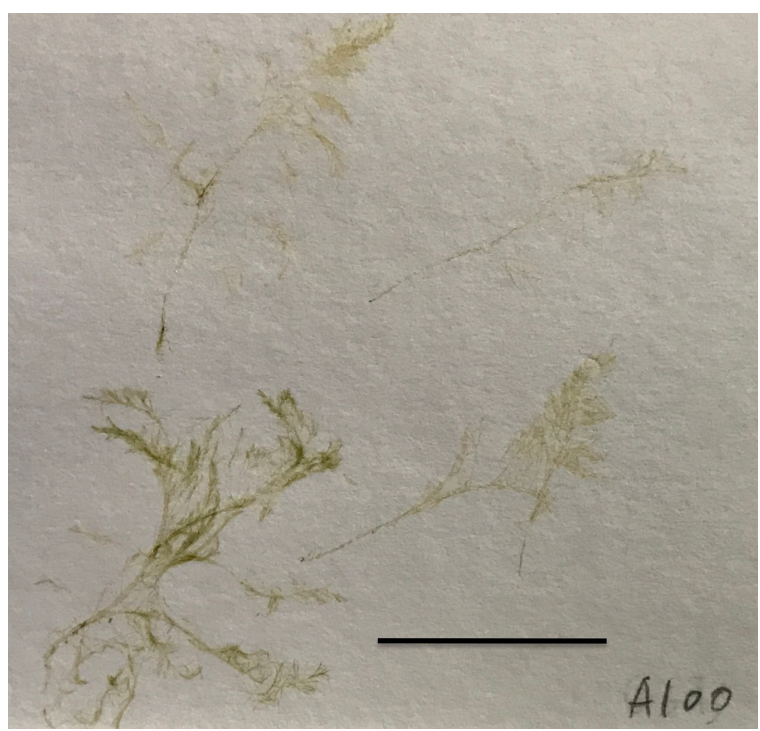

Figure 36. Sample Bryopsis sp. A100. Herbarium. Scale bar $=2 \mathrm{~cm}$.

Sample A100 is sister to and within a clade, based on tufA sequence data, of several Bryopsis samples: Bryopsis sp. (NC037363), Bryopsis sp. 28 (LK022446), Bryopsis sp. 24 (LK022445), Bryopsis sp. 21 (LK022440), Bryopsis sp. 20 (LK022452) and Bryopsidaceae sp. (KU361838), but without support bootstrap $(<50)$ (Fig. 37). The sample has $12.91 \%$ difference in tufA to the closest Genbank sequence and Blast hit, Bryopsis sp. (MK125425), that is not part of the clade containing sample A100. I 
designated sample A100 as Bryopsis sp. most closely similar to Bryopsis sp.

(MK125425) from Mallacoota, Victoria, Australia.

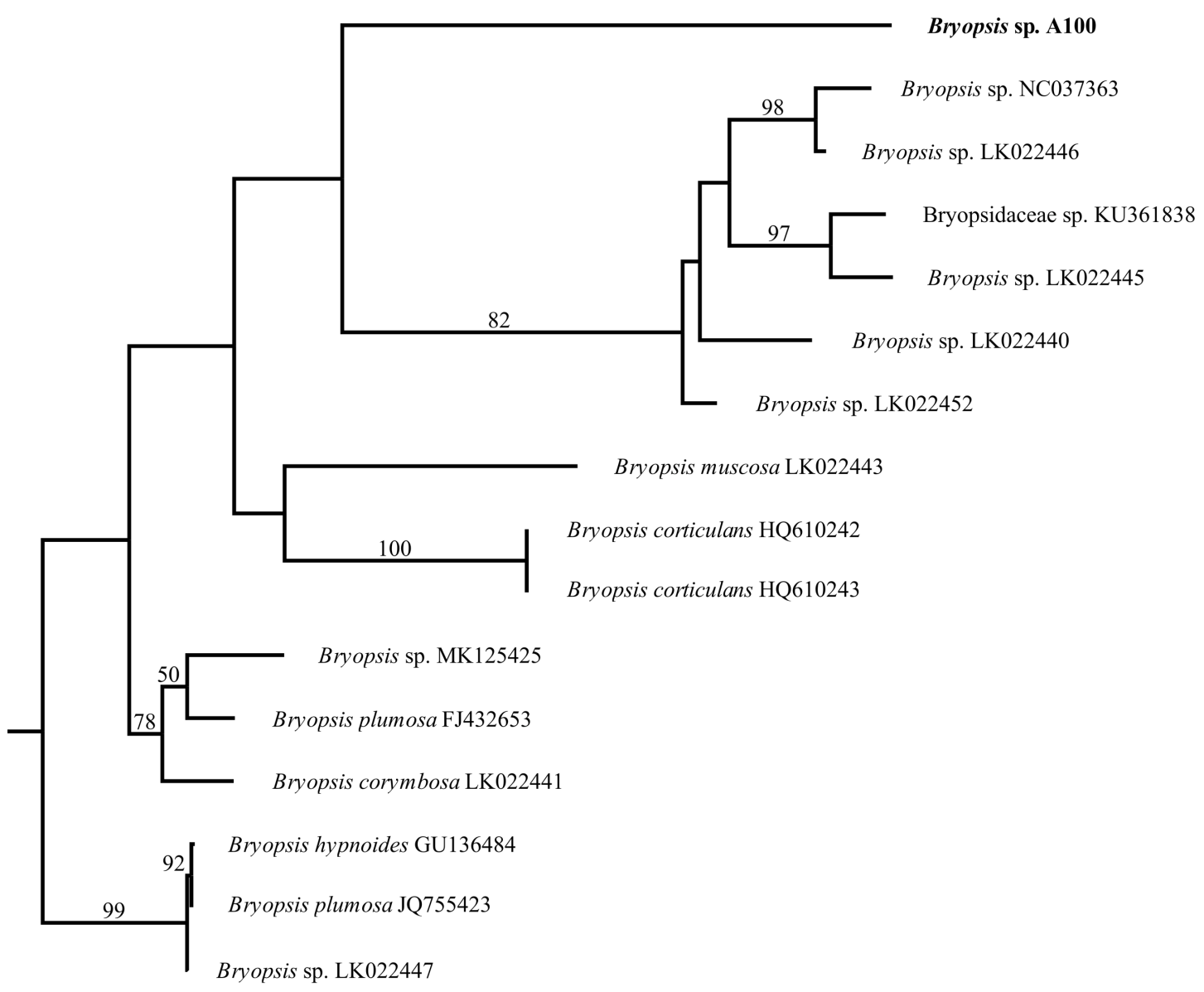

Figure 37. Maximum-likelihood tree of Bryopsis spp. using tufA gene sequences. Sample A100 shown. Derbesia marina (Lyngbye) Solier (HQ610250) was used as the outgroup. Only bootstrap support values $>50$ displayed. Scale bar $=0.3$ substitutions per site.

\section{Derbesia sp.}

Thalli of sample A35 (Fig. 38A, B) are siphonous unbranched filaments 60$100 \mu \mathrm{m}$ in diameter and up to $3 \mathrm{~cm}$ in length. The live specimen formed a dense turf of bright green filaments growing on coral rubble and across glass. 


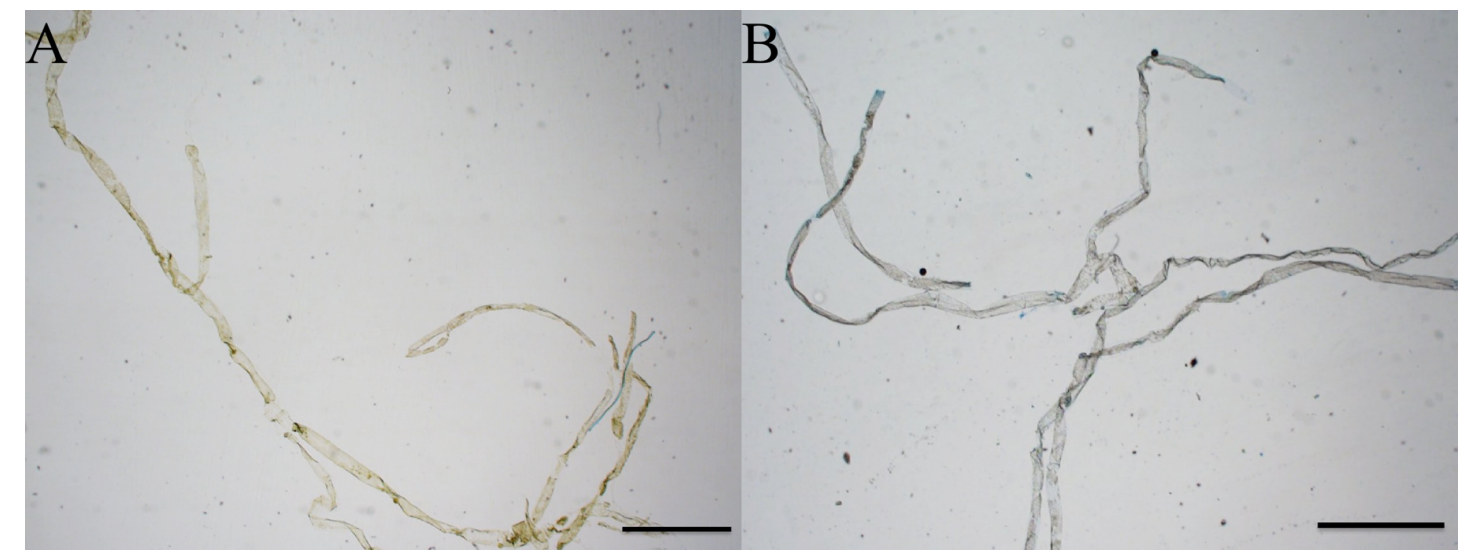

Figure 38. Sample of Derbesia sp. A35. Photomicrographs; A = unstained, B = stained with aniline blue. Scale bars $=1 \mathrm{~mm}$.

Sample A35 groups, based on tufA sequences data, with Derbesia sp.

(KU361859) with high support bootstrap (93\%) and in a clade (90\% bootstrap support)

with another Derbesia sp. sample (KU361860) (Fig. 39). The sample has $0.42 \%$ pairwise difference in tufA to Derbesia sp. (KU361859) its top Blast hit. I designated sample A35 as the same species as Derbesia sp. (KU361859) from Walton Rocks beach, Florida, USA.

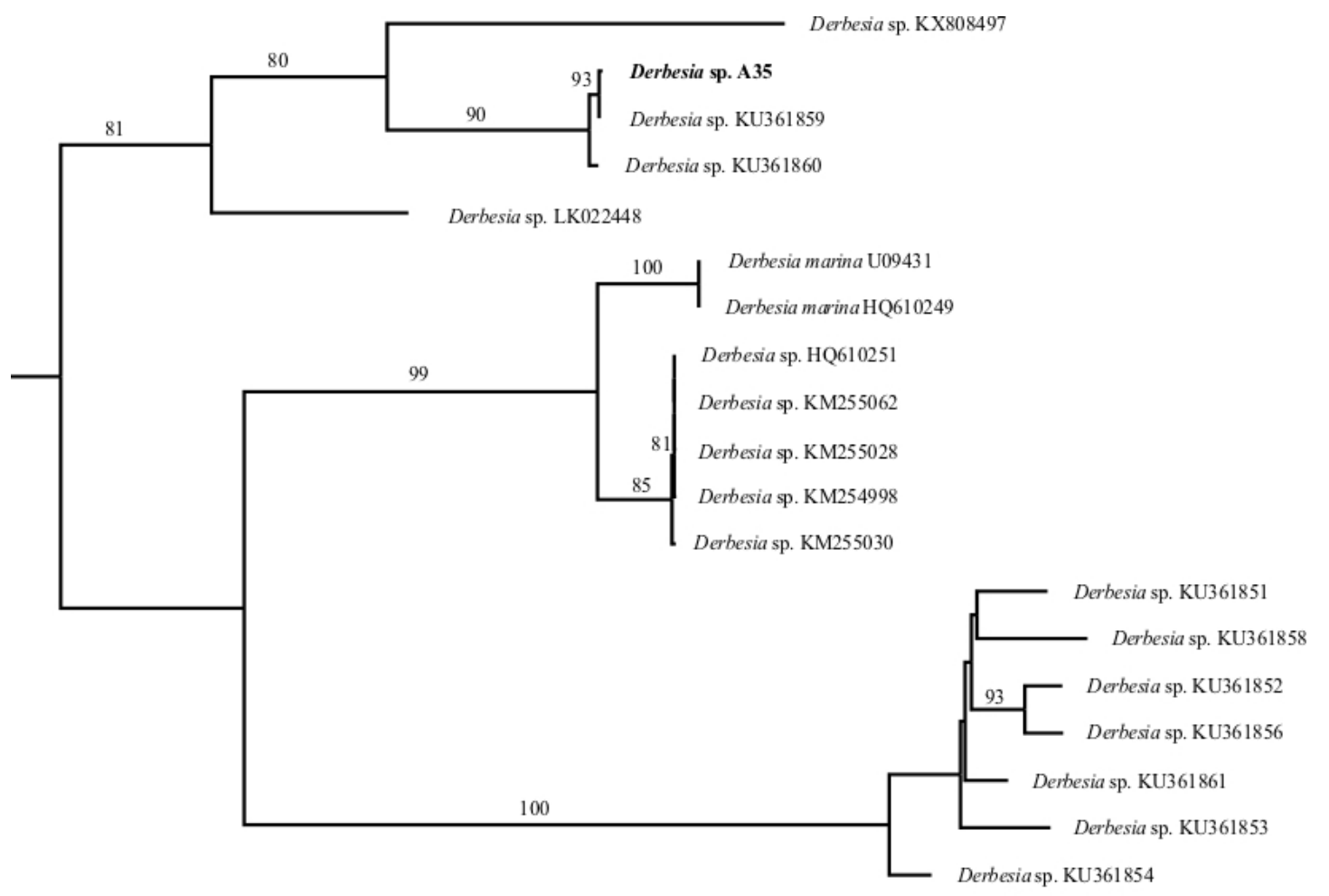

Figure 39. Maximum-likelihood tree of Derbesia sp. using tufA gene sequences. Sample 
A35 shown. Bryopsis plumosa (Hudson) C.Agardh (JQ755423) was used as the outgroup and was removed for clarity. Only bootstrap support values $>50$ displayed. Scale bar $=$ 0.3 substitutions per site.

\section{Halimeda sp.}

Sample A88 (Fig. 40); Solitary specimen on coral rock, erect, branched with segments in a single plane. Each segment bears a single daughter segment except for the $5^{\text {th }}$ segment that bears 5 daughter segments. Segments are lightly calcified but flexible and rubbery in texture when alive, light green pigmentation when fresh.

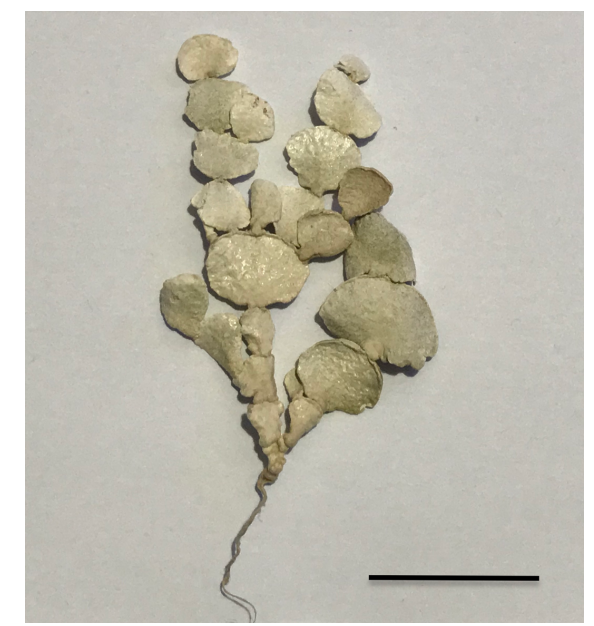

Figure 40. Sample Halimeda sp. A88. Herbarium. Scale bar $=2 \mathrm{~cm}$.

Sample A88 (Fig. 41) is sister, based on $r b c \mathrm{~L}$ sequences, to many of the species in the dataset. Sample A88 has 3.8\% pairwise difference in $r b c \mathrm{~L}$ to Halimeda discoidea Decaisne (AB700354, AB038488) and Halimeda magnidisca J.M.Noble (FJ624530). A88 has $4 \%$ pairwise difference in $r b c \mathrm{~L}$ to its top Blast hit Halimeda aff. tuna (KY570457). I designated sample A88 as Halimeda sp., possibly most similar to $H$. discoidea . 


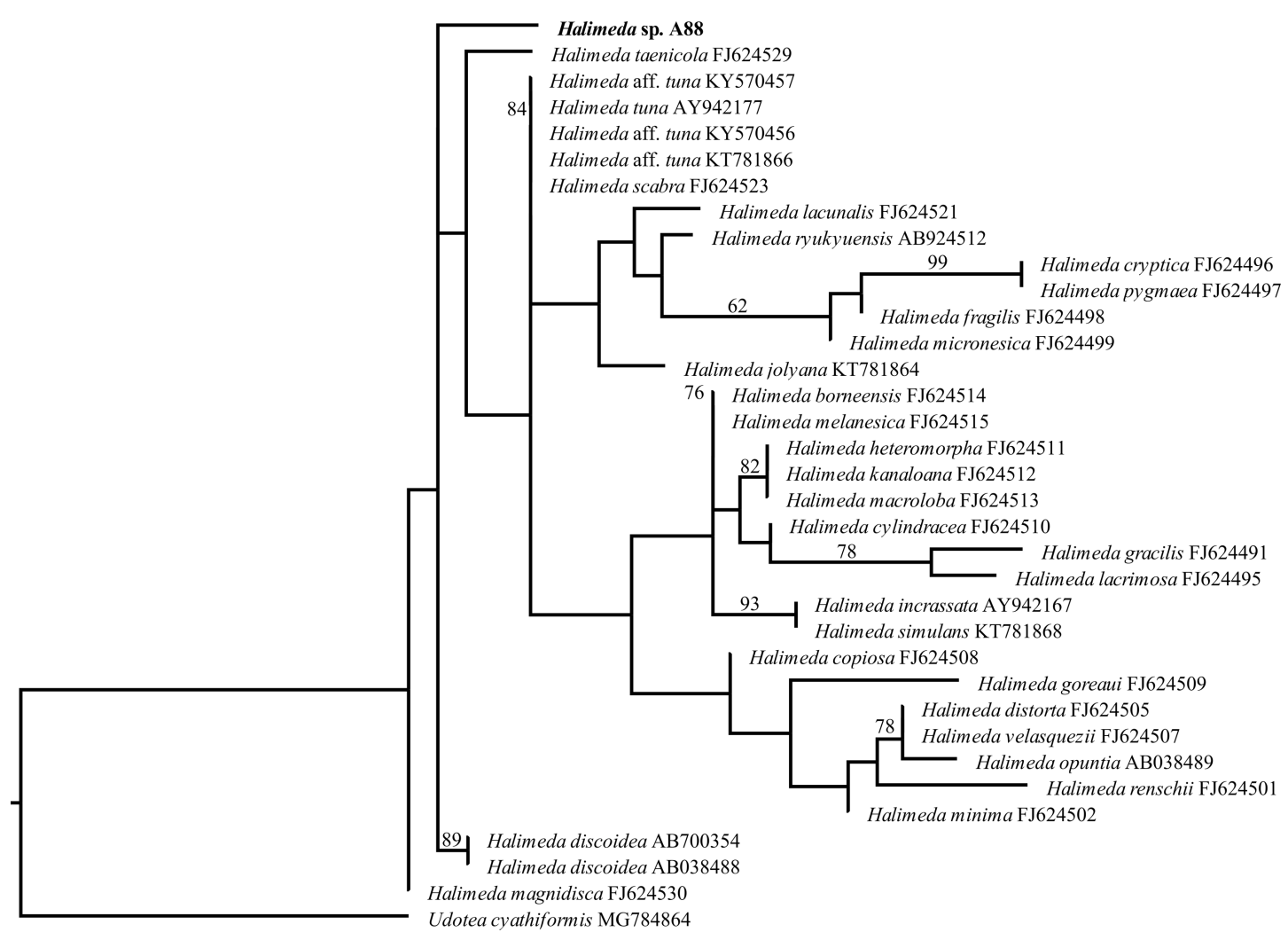

Figure 41. Maximum-likelihood tree of Halimeda sp. using partial $r b c \mathrm{~L}$ gene sequences. Sample A88 shown. Udotea cyathiformis L. (MG784864) was used as the outgroup. Only bootstrap support values $>50$ displayed. Scale bar $=0.4$ substitutions per site.

\section{Rhipidosiphon spp.}

Three specimens of Rhipidosiphon spp. were found, A20, A66 and A76, (Fig. 42).

They were green thalli erect of various sizes with rhizoidal holdfast, dichotomously branched siphons in a single plane on top of a short stipe, whole specimen looks like a fan. Sample A20 (Fig. 42A) appears to be lightly calcified. Sample A76 (Fig. 42B) has a stipe diameter of $120 \mu \mathrm{m}$, cells close to the stipe are $35-50 \mu \mathrm{m}$ in diameter, cells near edge of fan are $20 \mu \mathrm{m}$ in diameter. The whole specimen is $5 \mathrm{~mm}$ in height including the stipe and $6 \mathrm{~mm}$ in diameter across the widest point of the fan shaped structure. Sample A66 (Fig. 42C) is $4 \mathrm{~mm}$ in height including the stipe, and retains the deep green pigmentation from the live specimen. 

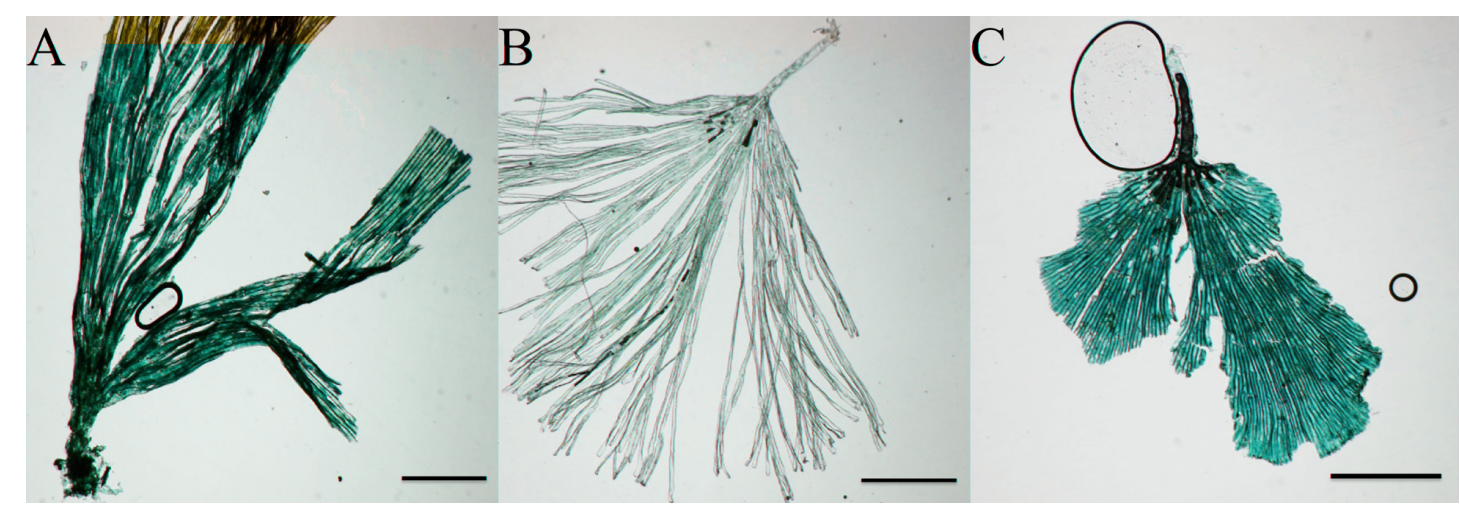

Figure 42. Examples of samples of Udotea sp. Photomicrographs; A = A20, B = A76, and $\mathrm{C}=$ A66. Scale bars $=1 \mathrm{~mm}$.

Sample A20 (Fig. 43) is sister, based on $r b c \mathrm{~L}$ sequences to Udotea glaucecens Harvey ex J.Agardh (FJ432650) with moderate support bootstrap (70\%). A20 is 1.3\% different in $r b c \mathrm{~L}$ to Udotea glaucecens (FJ432650) its closest pairwise sequence. Sample A20 is $4.3 \%$ different to the top Blast hit Rhipidosiphon sp. (AB700348). I designated A20 as Udotea glaucescens. 


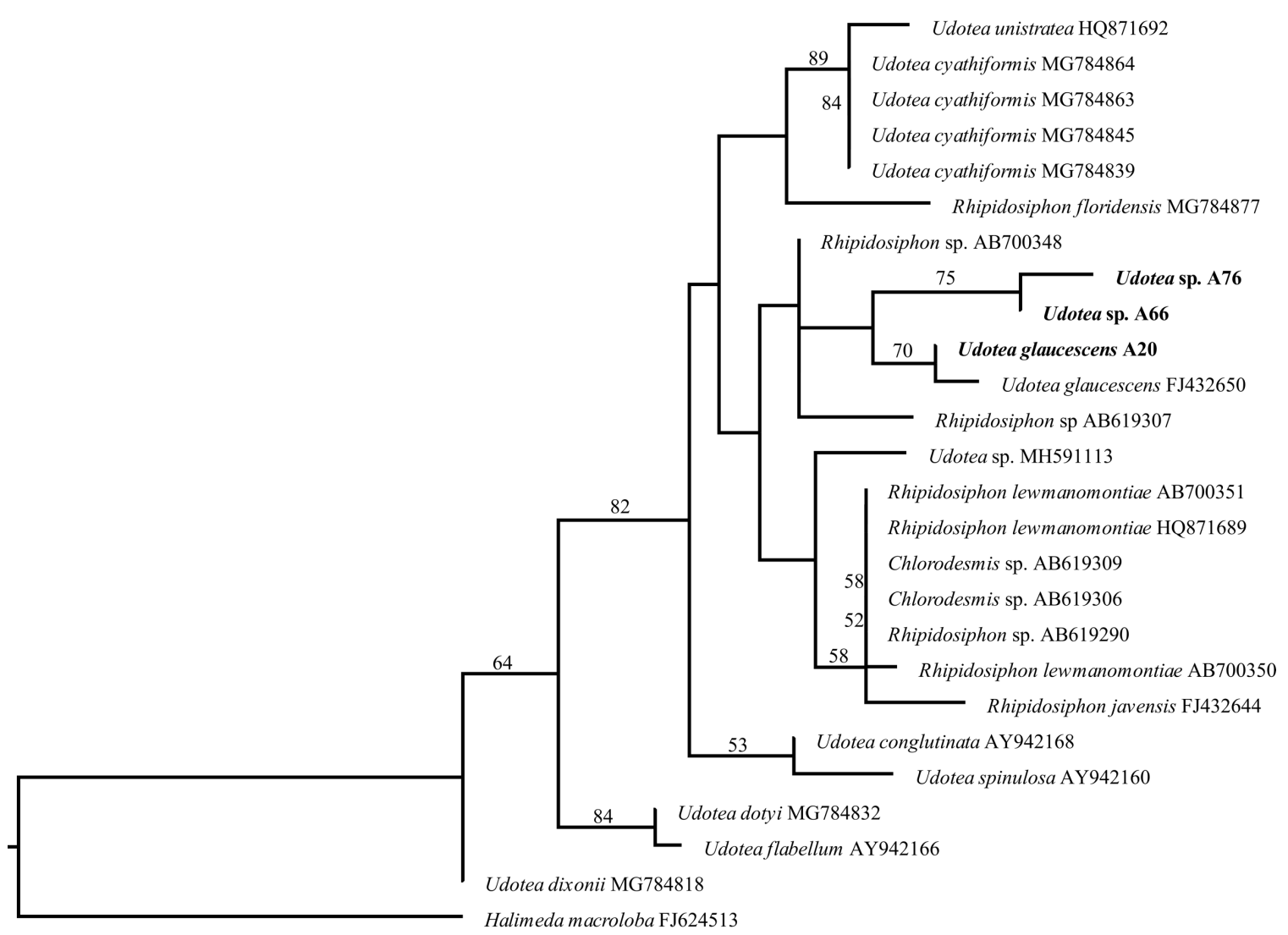

Figure 43. Maximum-likelihood tree of Udoteaceae using partial $r b c \mathrm{~L}$ gene sequences. Samples A20, A76, A66 shown. Halimeda macroloba Decaisne (FJ624513) was used as the outgroup. Only bootstrap support values $>50$ displayed. Scale bar $=0.02$ substitutions per site.

Samples A76 and A66 group together with moderate support bootstrap (75\%).

The samples have $2.8 \%$ difference in $r b c \mathrm{~L}$. A76 and A66 are within a clade containing sample A20 and Udotea glaucescens (FJ432650) without support bootstrap ( $<50 \%$ ). A76 is $4.7 \%$ different to the top Blast hit Udotea sp. (MH591113) from Zanzibar, Tanzania. I designate sample A76 as Udotea sp. Sample A66 has 4\% pairwise difference in $r b c L$ to the closest Genbank sequence and top Blast hit Udotea sp. (MH591113). I designated A66 as Udotea sp. 


\section{Caulerpa spp.}

A maximum-likelihood tree was built containing a total of 77 tufA gene sequences of Caulerpa spp. Samples A25, A27, A40, A41, A45 A79, A91, A111 were included. Caulerpella ambigua Okamura (KM186521) was used as the outgroup. The following trees for Caulerpa spp. are subsets from this full tree (Figure S1).

\section{Caulerpa cylindracea}

Sample A25 (Fig. 44) is a siphonous green alga with a thick stolon, $2.5 \mathrm{~mm}$ diameter, thick assimilators, $2 \mathrm{~mm}$ diameter and 4-5 $\mathrm{cm}$ length, with one row of elongate ramuli with rounded tips on opposite sides of the assimilator. Some assimilators have slightly enlargement above their attachment to the stolon, many rhizoids are present along the stolon, up to $2 \mathrm{~cm}$ length.

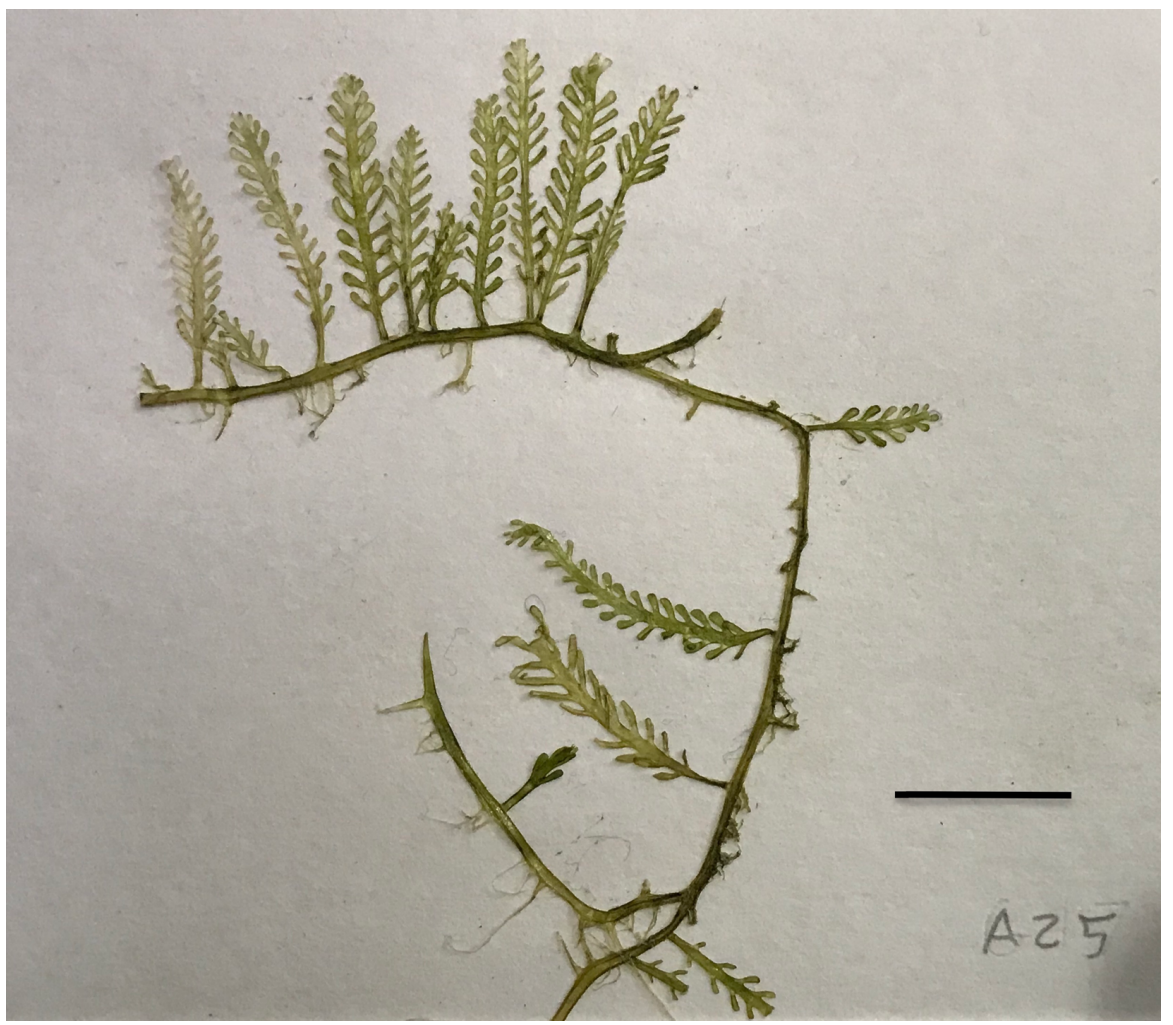

Figure 44. Sample A25 Caulerpa cylindracea. Herbarium voucher. Scale bar $=2 \mathrm{~cm}$. 
Specimen A25 is within a clade, based on the full maximum-likelihood tree (Fig. S1) of Caulerpa spp. tufA sequence data, containing Caulerpa okamurae Weber Bosse (KX809677), Caulerpa cylindracea and Caulerpa racemosa with high support bootstrap (99\%). A25 is identical to all the sequences in the clade including the top Blast hit Caulerpa cylindracea (FM956048). I designated specimen A25 as Caulerpa cylindracea.

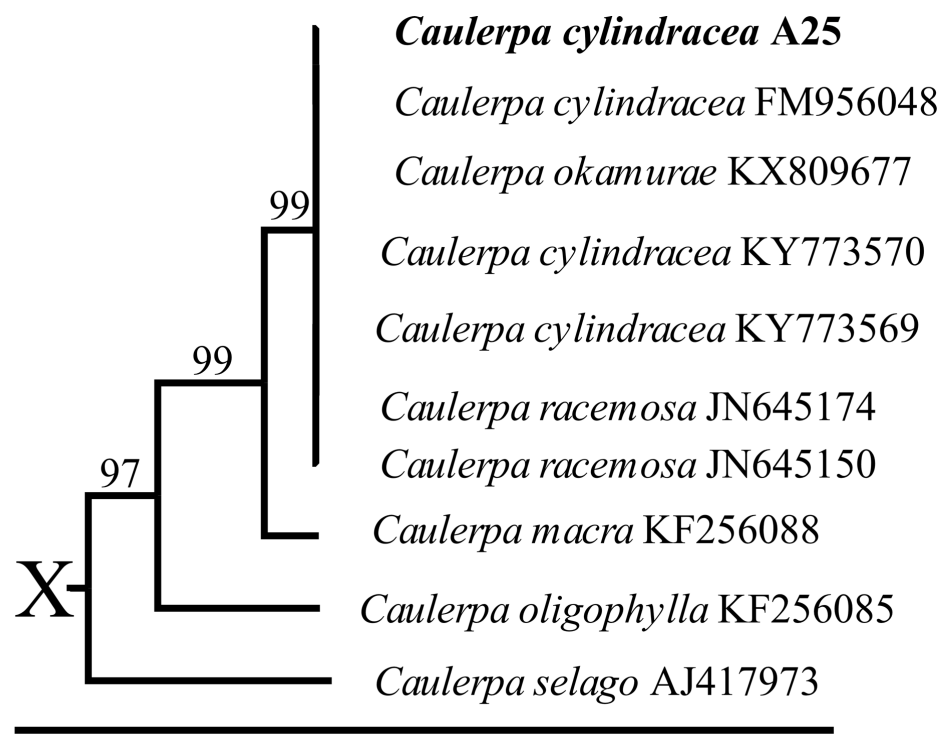

Figure 45. Clade removed from the full tufA maximum-likelihood tree of Caulerpa spp. Specimen A25 shown. Only bootstrap support values $>50$ displayed. Scale bar $=0.1$ substitutions per site. X shows where the clade was removed from the full tree.

\section{Caulerpa lentillifera}

Sample A26 (Fig. 46) is a siphonous green alga with thin assimilators, 1-1.5mm diameter, 2-6 cm long, with rounded ramuli, 1-1.5 mm diameter. Assimilators have ramuli along entire length except for 5-7 $\mathrm{mm}$ from attachment to the infrequently branched stolon, many short rhizoids are present along the length of the stolon. 


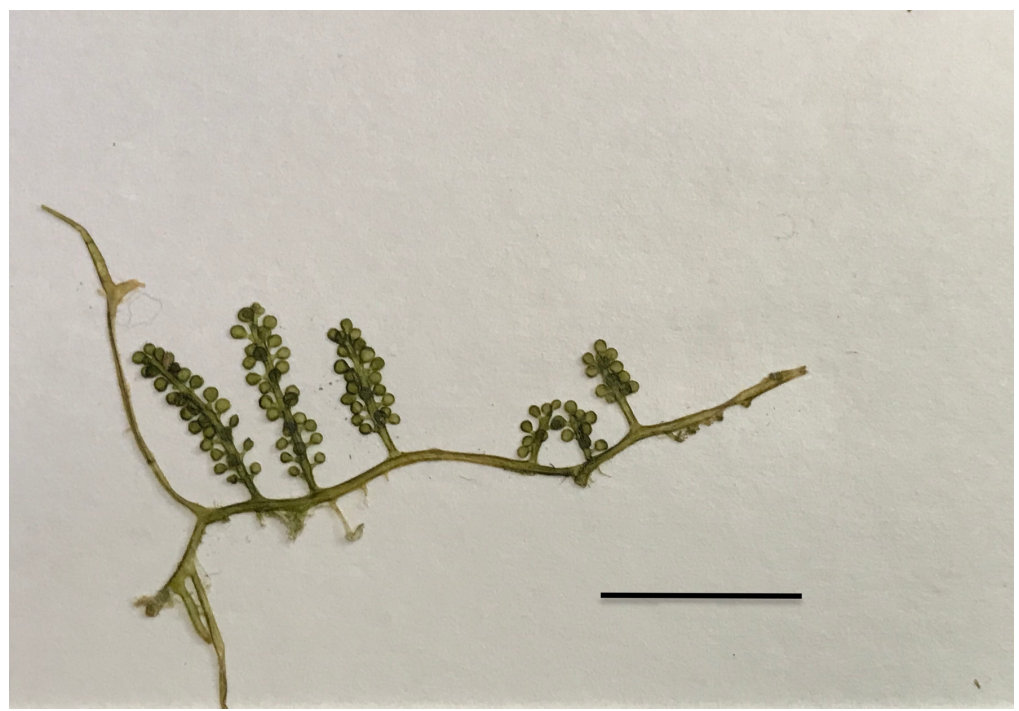

Figure 46. Sample A26 Caulerpa lentillifera. Herbarium voucher. Scale bar $=2 \mathrm{~cm}$.

Sample A26 is within a clade, based on the full maximum-likelihood tree (Fig. S1) of Caulerpa spp. tufA containing Caulerpa lentillifera J.Agardh and Caulerpa microphysa (Weber Bosse) W.R.Taylor with high support bootstrap (100\%)(Fig. 47). Sample A26 is identical to all Genbank sequences in the clade including its top Blast hit Caulerpa lentillifera (NC039377), and excluding Caulerpa microphysa (DQ652518). I designated A26 as Caulerpa lentillifera. 


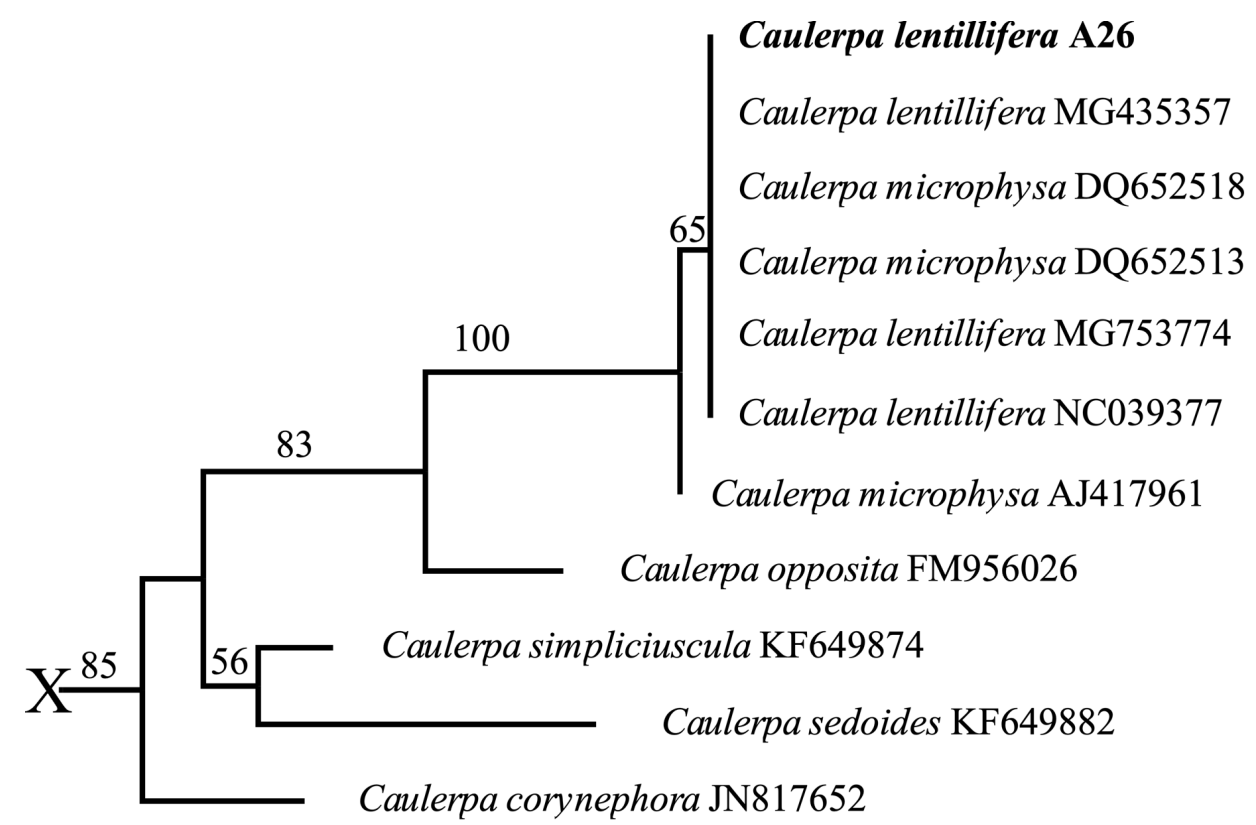

Figure 47. Clade from the full tufA maximum-likelihood tree of Caulerpa spp. using tufA sequence data. Specimen A26 shown. Only bootstrap support values $>50$ displayed. Scale bar $=0.1$ substitutions per site. $X$ shows where the clade was removed from the full tree.

\section{Caulerpa sp.}

Sample A41 (Fig. 48A) is a siphonous green alga with thin assimilators $<0.5 \mathrm{~mm}$ diameter, $<2 \mathrm{~cm}$ long and few flattened mushroom-shaped ramuli, with thin stolons, $<0.5$ $\mathrm{mm}$ in diameter, and has many short rhizoids, $<7 \mathrm{~mm}$ length.

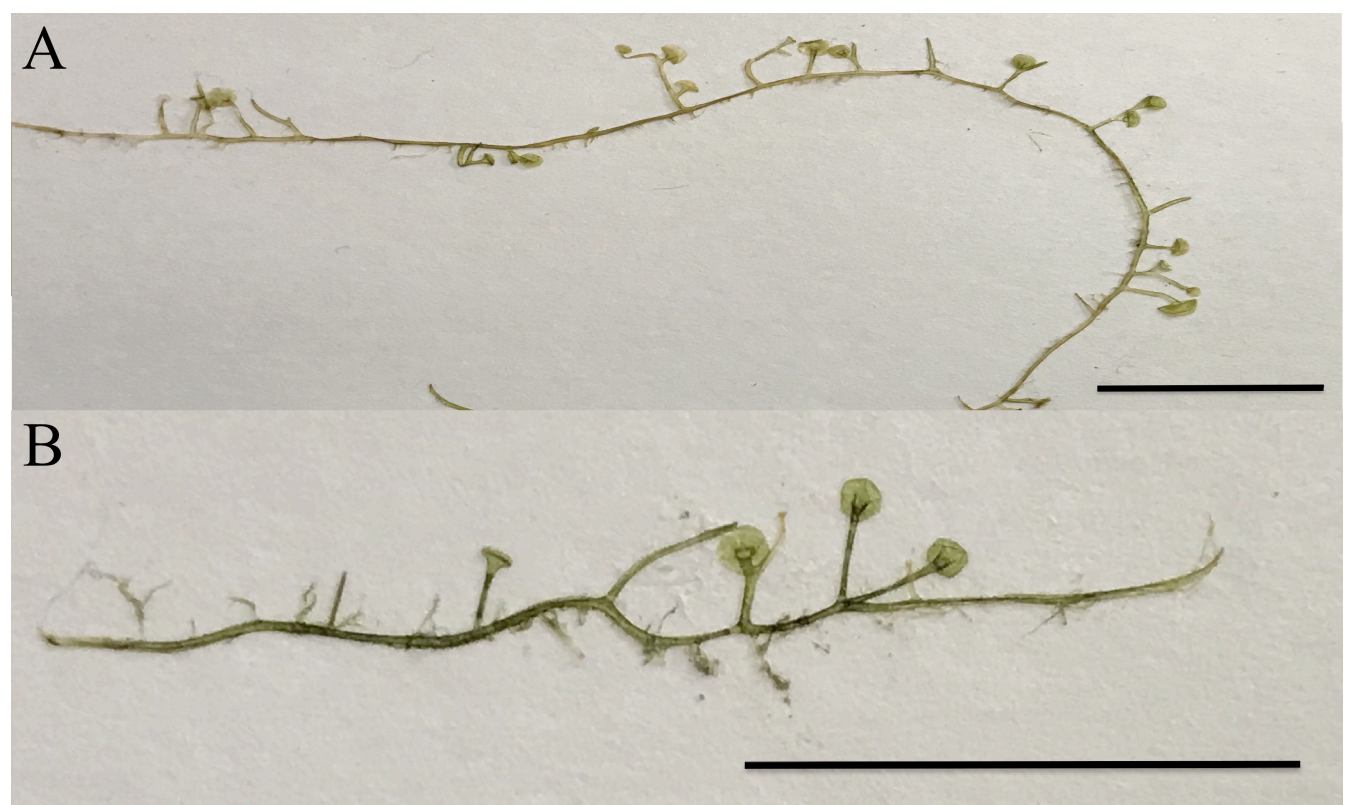

Figure 48. Samples of Caulerpa spp. Herbariums; A = Caulerpa selago A41 scale bar = $2 \mathrm{~cm} . \mathrm{B}=$ Caulerpa chemnitzia A91 scale bar $=2 \mathrm{~cm}$. 
Sample A91 (Fig. 48B) is a siphonous green alga with thin assimilators, $0.5 \mathrm{~mm}$ diameter, $<2 \mathrm{~cm}$ long and some flattened mushroom-shaped ramuli, with thin stolons, $<0.5 \mathrm{~mm}$ in diameter, and has many short rhizoids, $<7 \mathrm{~mm}$ length.

Sample A41 is sister, based on the full maximum-likelihood tree (Fig. S1) of Caulerpa spp. tufA to Caulerpa selago (Turner) C.Agardh (FM956061) from Indonesia with moderate support bootstrap (78\%) (Fig. 49). A41 is identical in tufA to its sister Caulerpa selago (FM956061) and its top Blast hit Caulerpa racemosa (DQ652466). The difference in phylogenetic placement may be due to different sequence lengths. I designated sample A41 as Caulerpa selago. 


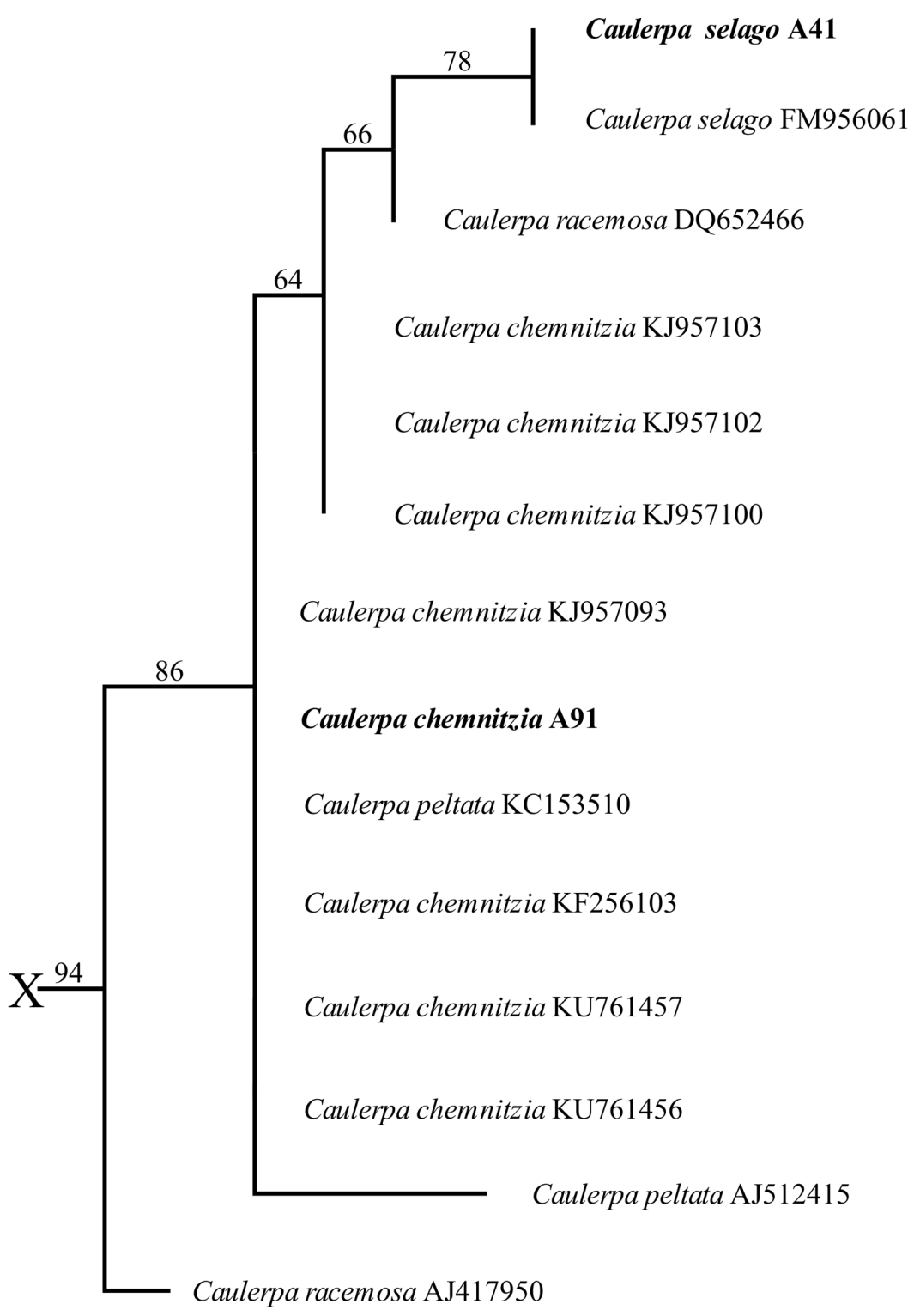

Figure 49. Clade from the full tufA maximum-likelihood tree of Caulerpa spp. using tufA sequence data. Specimens A41 and A91 shown. Only bootstrap support values $>50$ displayed. Scale bar $=0.025$ substitutions per site. $X$ shows where the clade was removed from the full tree.

The clade containing sample A91, also contains sequences named Caulpera peltata J.V.Lamouroux (KC153510, AJ512415), 7 sequences of C. chemnitzia (Esper) J.V.Lamouroux, C. racemosa (AJ417950, DQ652466), C. selago (FM956061) and sample A41, excluding C. racemosa (AJ417950) with high support bootstrap (86\%). Sample A91 has 0.1\% pairwise difference to the top Blast hit C. chemnitzia (KJ957093) and $C$. chemnitzia KF256103, KU761457, KU761456) and C. peltata (KC153510). C. 
peltata has been synonomised with C. chemnitzia (Belton et. al. 2014). I designated sample A91 as Caulerpa chemnitzia.

\section{Caulerpa sp.}

Sample A40 (Fig. 50) is a siphonous green alga with flattened or slightly rounded mushroom shape ramuli, thin assimilators, $0.70 \mathrm{~mm}$ diameter, with few ramuli, $<7$, the stolon is $0.7 \mathrm{~mm}$ diameter. Rhizoids, $<1 \mathrm{~cm}$ length, are frequent along the stolon, rhizoids are larger close to the assimilators.

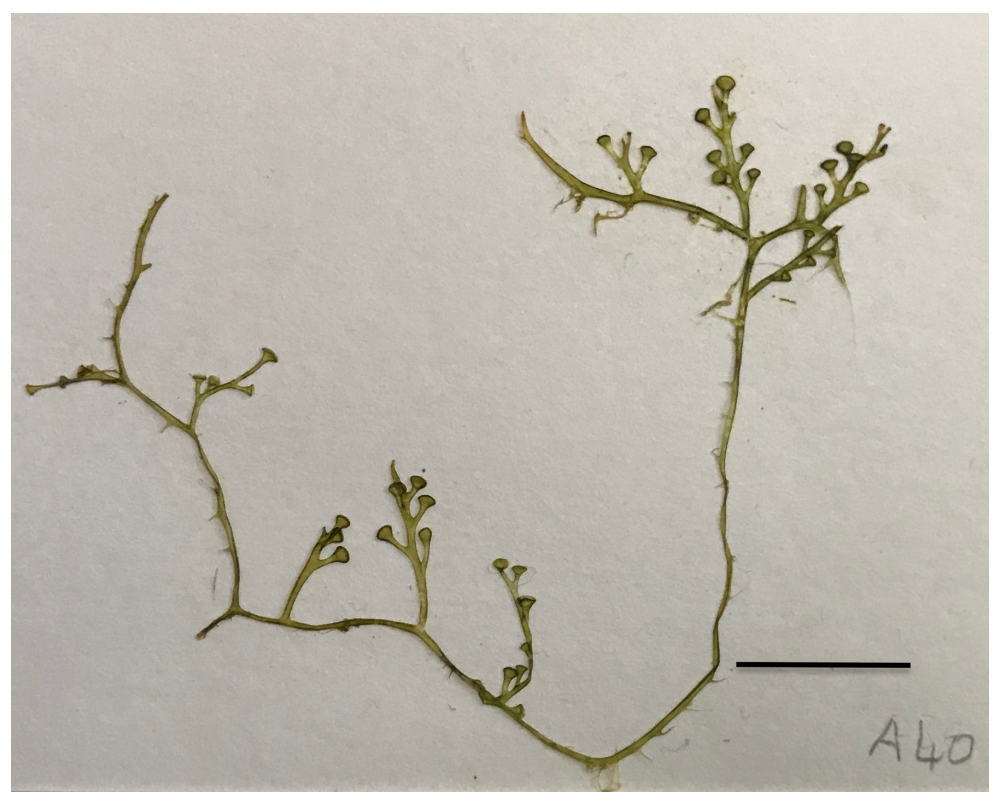

Figure 50. Sample Caulerpa racemosa var. macrophysa A40. Herbarium voucher. Scale bar $=2 \mathrm{~cm}$.

Sample A40 is within a clade, based on the full maximum-likelihood tree (Fig. S1) of Caulerpa spp. tufA sequence, containing Caulerpa racemosa f. macrophysa (Sonder ex Kützing) Svedelius with full bootstrap support (Fig. 51). A40 is identical in tufA to the top Blast hit Caulerpa racemosa f. macrophysa (KJ957088) and sequences Caulerpa racemosa f. macrophysa (KJ957087, KJ957085, KJ957086, KJ957084). The entity Caulerpa racemosa f. macrophysa has been synomonised with Caulerpa racemosa 
var. macrophysa (Sonder ex Kützing) W.R.Taylor. I designated specimen A40 as Caulerpa racemosa var. macrophysa.

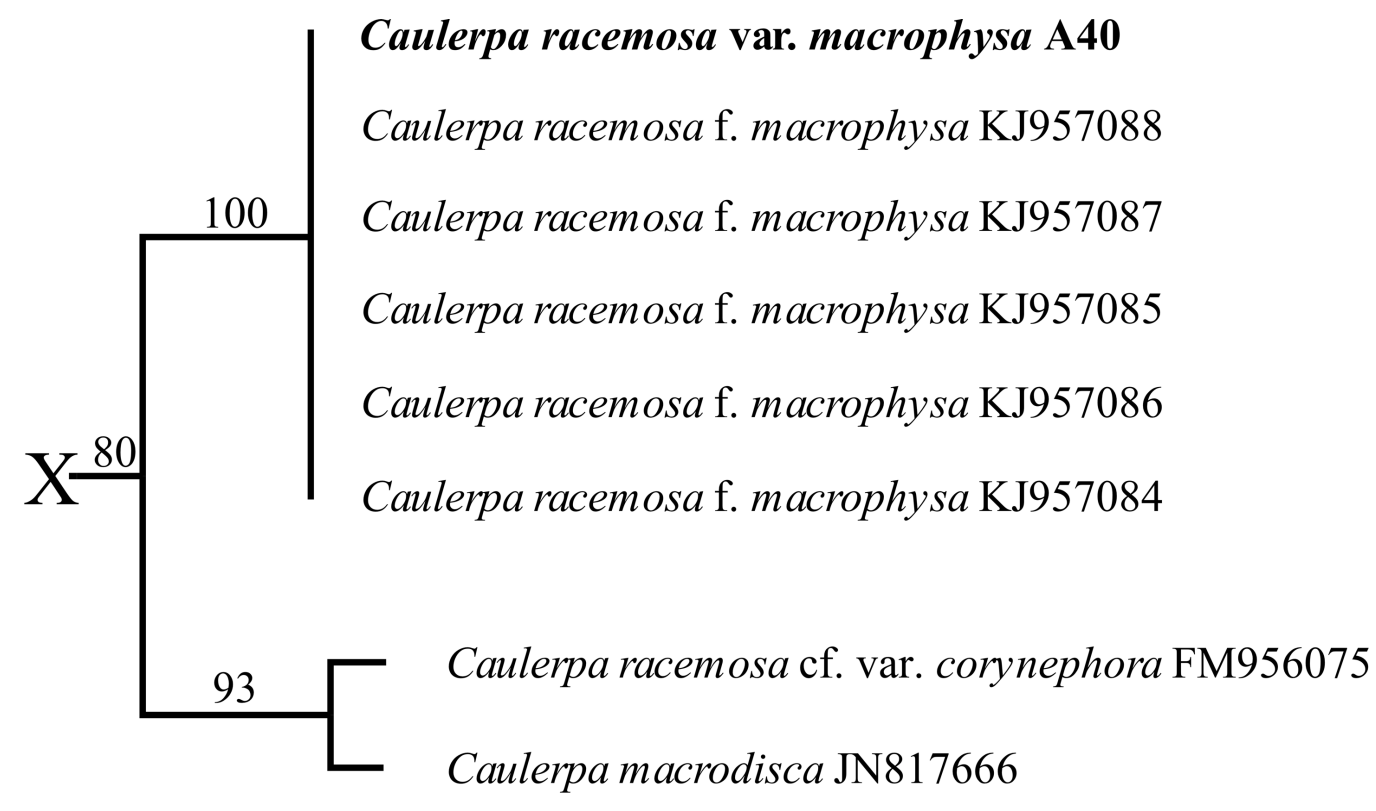

Figure 51. Clade from the full tufA maximum-likelihood tree of Caulerpa spp. using tufA sequence data. Sample A40 shown. Only bootstrap support values $>50$ displayed. Scale bar $=0.1$ substitutions per site. $\mathrm{X}$ shows where the clade was removed from the full tree.

\section{Caulerpa serrulata}

Sample A45 (Fig. 52) is a siphonous green alga with a thick stolon, $2 \mathrm{~mm}$ in diameter, short assimilators with flat dichotomous branching blades with serrated margins. The short rhizoids are spaced irregularly along the stolon. 


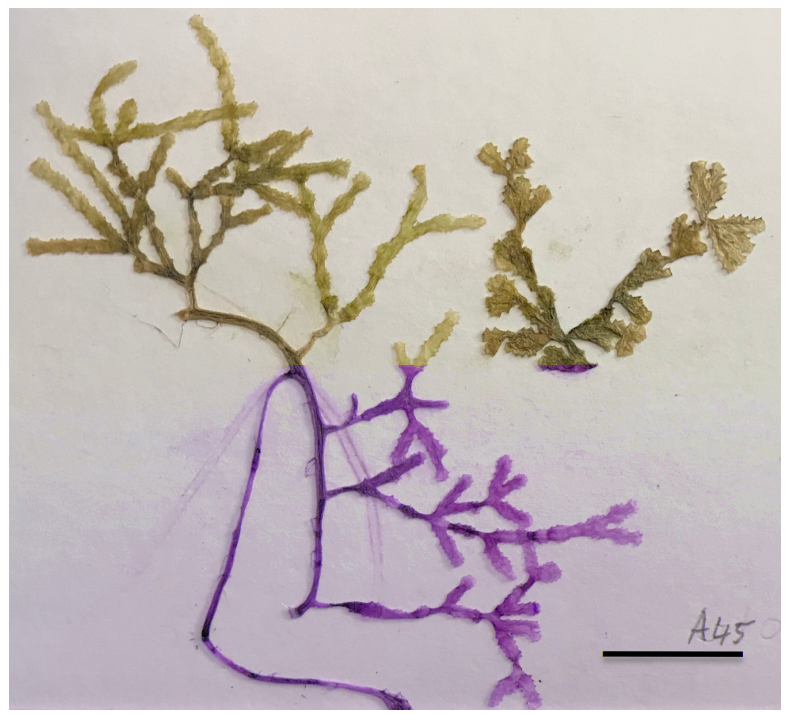

Figure 52. Sample Caulerpa serrulata A45 herbarium. Scale bar $=2 \mathrm{~cm}$.

Sample A45 is within a clade, based on the full maximum-likelihood tree (Fig. S1) of Caulerpa spp. tufA sequences, containing mostly sequences from samples identified as Caulerpa serrulata and but also a samples identified as Caulerpa cupressoides (Vahl) C.Agardh (DQ652336) with moderate support bootstrap (81\%)(Fig. 53). Sample A45 has $0.12 \%$ pairwise difference from the top Blast hit Caulerpa serrulata (KJ957119, KF314147, DQ652346). I designated sample A45 as Caulerpa serrulata. 


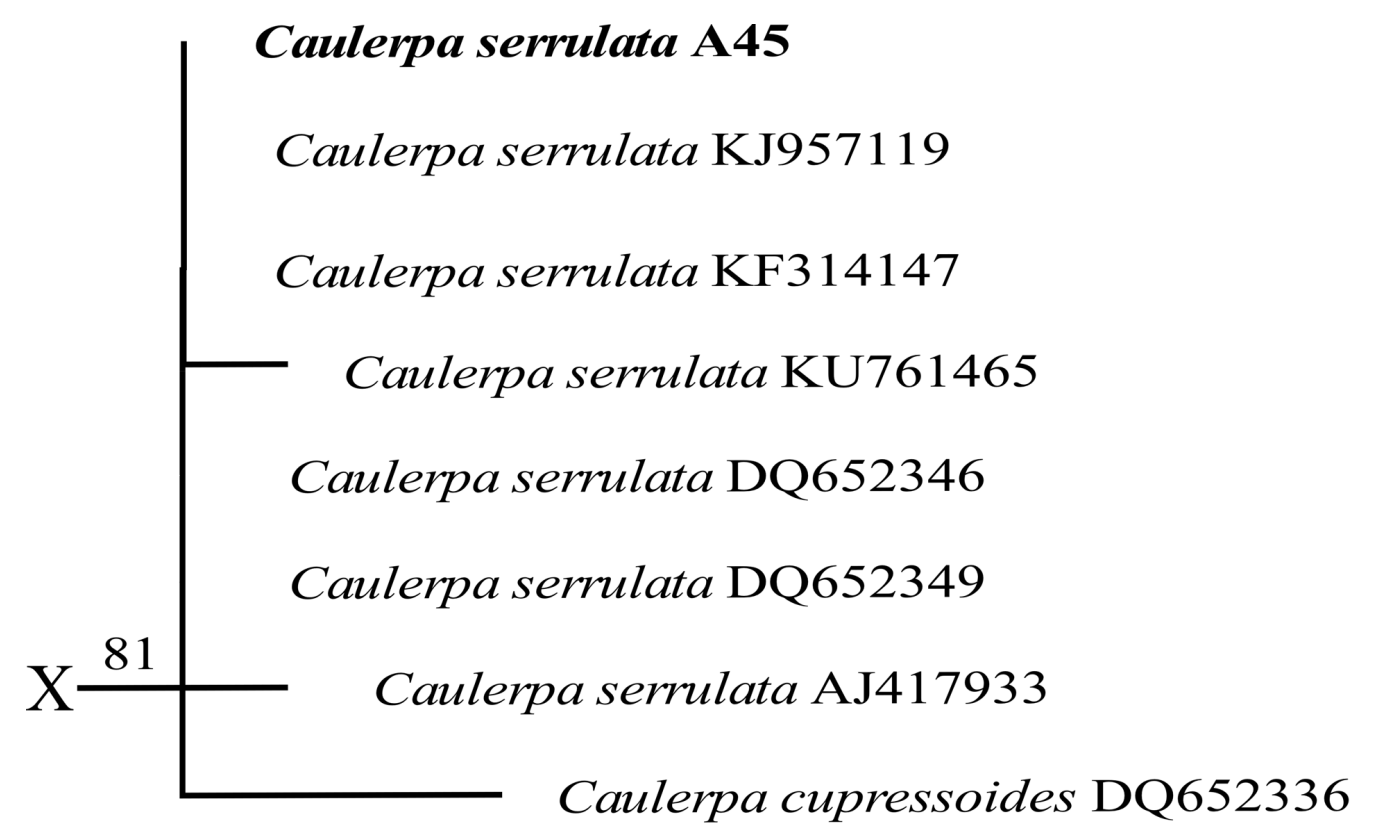

Figure 53. Clade from the full tufA maximum-likelihood tree of Caulerpa spp. using tufA sequence data. Sample A45 shown. Only bootstrap support values $>50$ displayed. Scale bar $=0.025$ substitutions per site. $X$ shows where the clade was removed from the full tree.

Caulerpa spp.

Sample A79 (Fig. 54A) is a siphonous green alga with flattened mushroom shaped ramuli, assimilators are thin, $<0.5 \mathrm{~mm}$ diameter and $<2 \mathrm{~cm}$ long, with few ramuli, the stolon is thin, $<0.5 \mathrm{~mm}$ diameter, and has many short rhizoids, $<7 \mathrm{~mm}$ length.

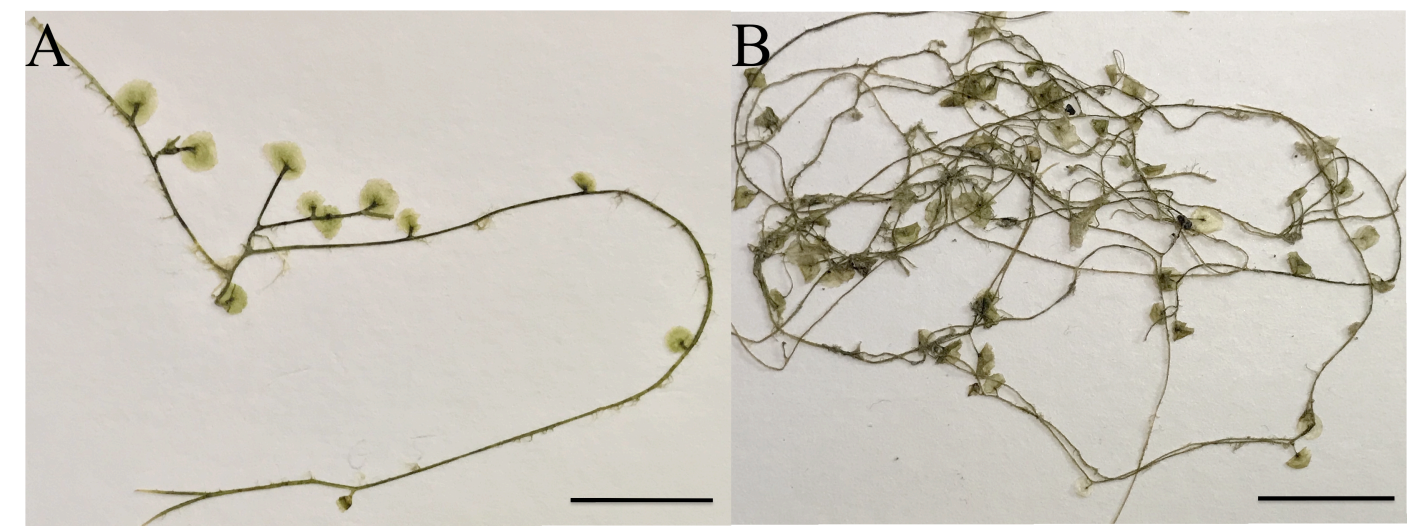

Figure 54. Samples A79 and A111, Caulerpa sp., herbariums A = A79, B = A111. Scale bar $=2 \mathrm{~cm}$ 
Sample A111 (Fig. 54B) is a siphonous green alga with flattened mushroom shaped ramuli, assimilators are thin, $<0.5 \mathrm{~mm}$ diameter and $<2 \mathrm{~cm}$ long, with few ramuli. The stolon is thin, $<0.5 \mathrm{~mm}$ diameter, and has many short rhizoids, $<7 \mathrm{~mm}$ length.

Sample A79 is within a basal section, based on the full maximum-likelihood tree (Fig. S1) of Caulerpa spp. tufA sequence data, containing uncultured Ulvophyceae (GU592622, GU592621, GU592606), sample A111, Caulerpa nummularia Harvey ex J.Agardh (JN851138, KF256098) and Caulerpa racemosa (DQ652426) with no bootstrap support $(<50 \%)$ (Fig. S1). Sample A79 is identical in tufA to the top Blast hit Caulerpa racemosa (DQ652426), and sequences named uncultured Ulvophyceae (GU592606) and Caulerpa nummularia (JN851138). I designated sample A79 as Caulerpa racemosa. Sample A111 has $0.13 \%$ pairwise difference to the top Blast hit Caulerpa nummularia (JN851138) from Australia. I designated sample A111 as Caulerpa nummularia.

\section{Caulerpa sertularioides}

Sample A78 is a siphonous green alga with feather like assimilators that are between 1.5 and $2.5 \mathrm{~cm}$ in length and $1 \mathrm{~mm}$ in diameter. The assimilators are dark green and are frequent along the stolon. The stolon is moderately thick $1 \mathrm{~mm}$ in diameter. Cylindrical pinnules, ending in sharp points are present on opposite sides of the assimilator, giving the alga a feathery appearance. Rhizoids are present on short off branches from the stolon. This sample was not sequenced so we have no molecular identification. I designated specimen, A78, as Caulerpa sertularioides (S.G.Gemlin) M.Howe. 


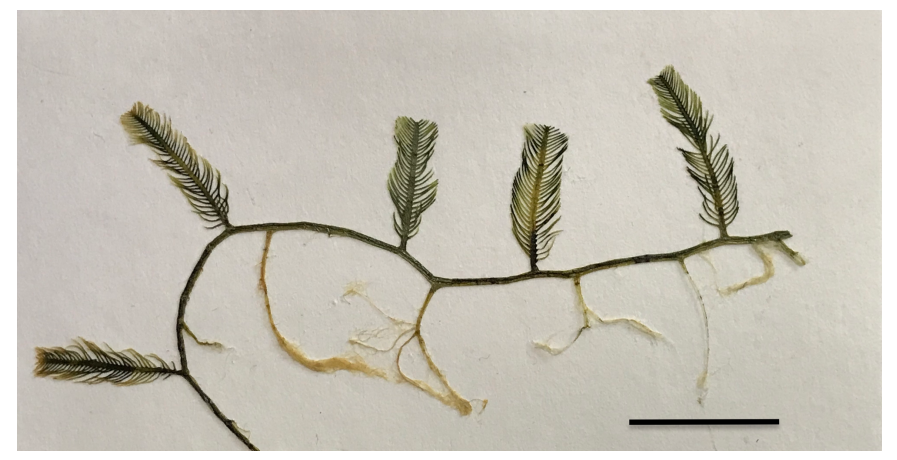

Figure 55. Herbarium of sample A78 Caulerpa sp. Scale bar $=2 \mathrm{~cm}$.

\subsection{Identification brown algae}

Dictyopteris sp. and Dictyota sp.

Sample A109 (Fig. 56A) is a dichotomously branched brown alga with a visible midrib. Branch tips are pale and there are two clusters of apical cells and a midrib, typical of Dictyopteris species. Sample A110 (Fig. 56B) is dichotomously branched with no midrib visible. Sample A5 (Fig. 56C) was not sequenced but has morphology typical of Dictypoteris sp. (dichotomous branching thallus, a visible midrib and 1 cell layer thick). Micrographs of samples A59 unsequenced and A62 Dictyota sp1 were included in (Fig. S4).
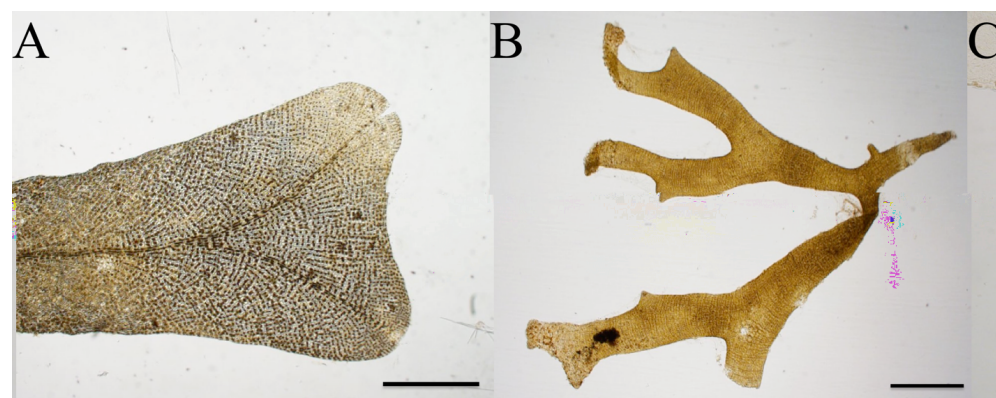

Figure 56. Samples of Dictyota sp. and Dictyopteris spp. Photomicrographs; $\mathrm{A}=$ Dictyopteris sp. A109 scale bar $=1 \mathrm{~mm}$. B = Dictyota $\mathrm{sp}$. A110 scale bar $=1 \mathrm{~mm}, \mathrm{C}=$ Dictyopteris sp. A5 unsequenced Dictyopteris sp., scale bar $=400 \mu \mathrm{m}$. 
Sample A62 is sister to its top Blast hit Dictyota friabilis Setchell (GU290244)

with moderate bootstrap support (88\%)(Fig. 57). The sample is most similar to Dictyota friabilis (GU290244) from Oahu Hawaii with 6.24\% pairwise difference. I designated sample A62 as Dictyota sp1, most closely related to Dictyota friabilis (GU290244).

Sample A110 does not cluster with any other sequence. A110 is $10.03 \%$ different from Dictyota friabilis (GU290244) its closest pairwise sequence and top Blast hit. I designated sample A110 as Dictyota sp2.

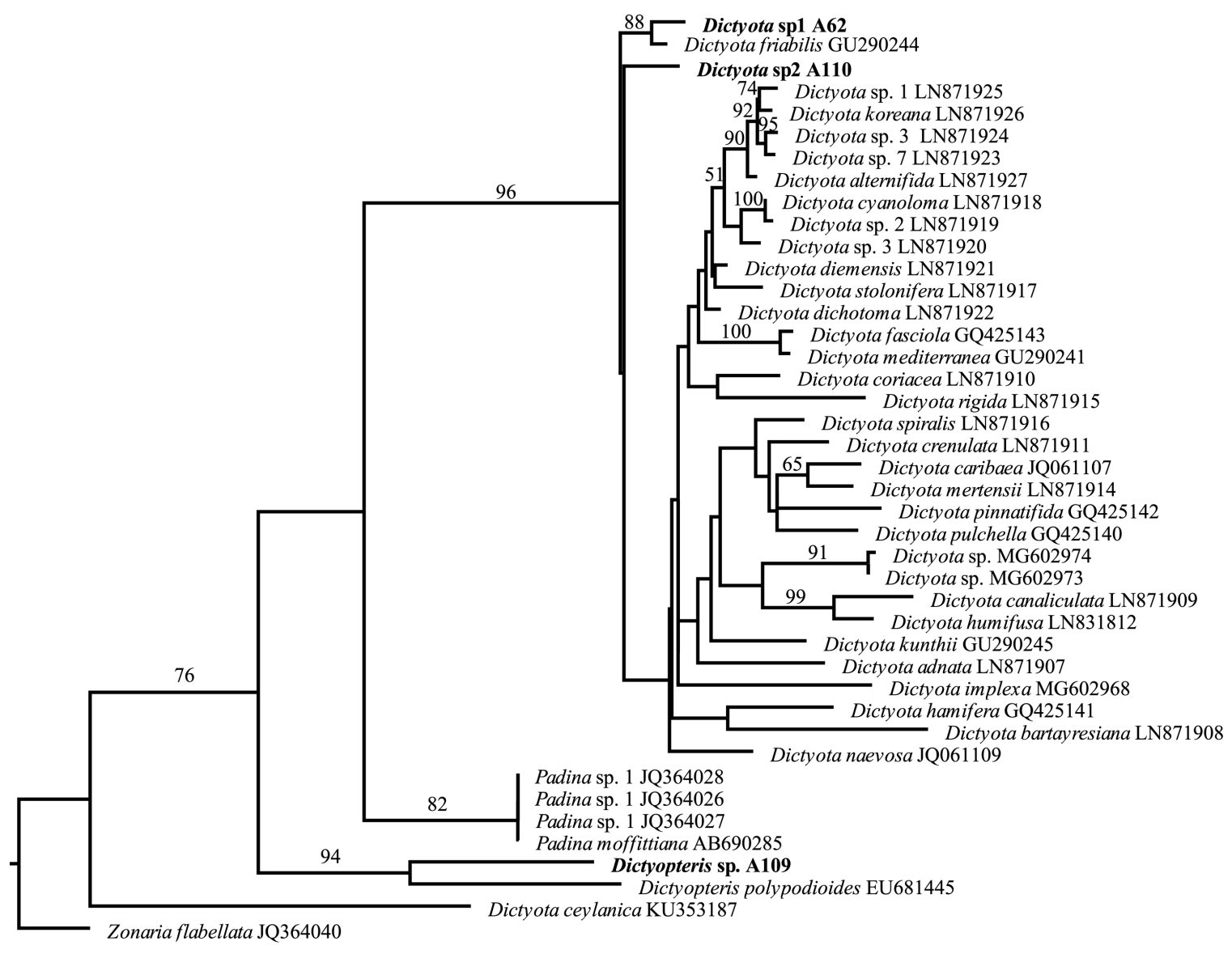

Figure 57. Maximum-likelihood tree of Dictyota spp. using cox3 gene sequences. Samples A62, A109 and A110 shown. Zonaria flabellata (JQ364040) was used as the outgroup. Only bootstrap support $>50$ displayed. Scale bar $=0.4$ substitutions per site. 
Sample A109 is sister, based on cox3 sequences, to Dictyopteris polypodioides (A.P.Candolle) J.V.Lamouroux (EU681445) with high bootstrap support (94\%). The sample is $19.26 \%$ pairwise different in cox3 to Dictyopteris polypodioides (EU681445) its top Blast hit. I designated sample A109 as Dictyopteris sp.

Turbinaria ornata

No voucher specimen of A6 is available as the whole sample was required for DNA extraction.

Sample A6 (Fig. 58) groups, based on cox3 sequences, with Turbinaria ornata (Turner) J.Agardh (KN501562) with high bootstrap support (97\%). These are in a larger clade with another Turbinaria ornata sample (KY935437) with full bootstrap (100\%). Sample A6 has $0.73 \%$ pairwise difference in cox3 to the closest Genbank sequence and top Blast hit Turbinaria ornata (KM501562). I designated sample A6 as Turbinaria ornata. 


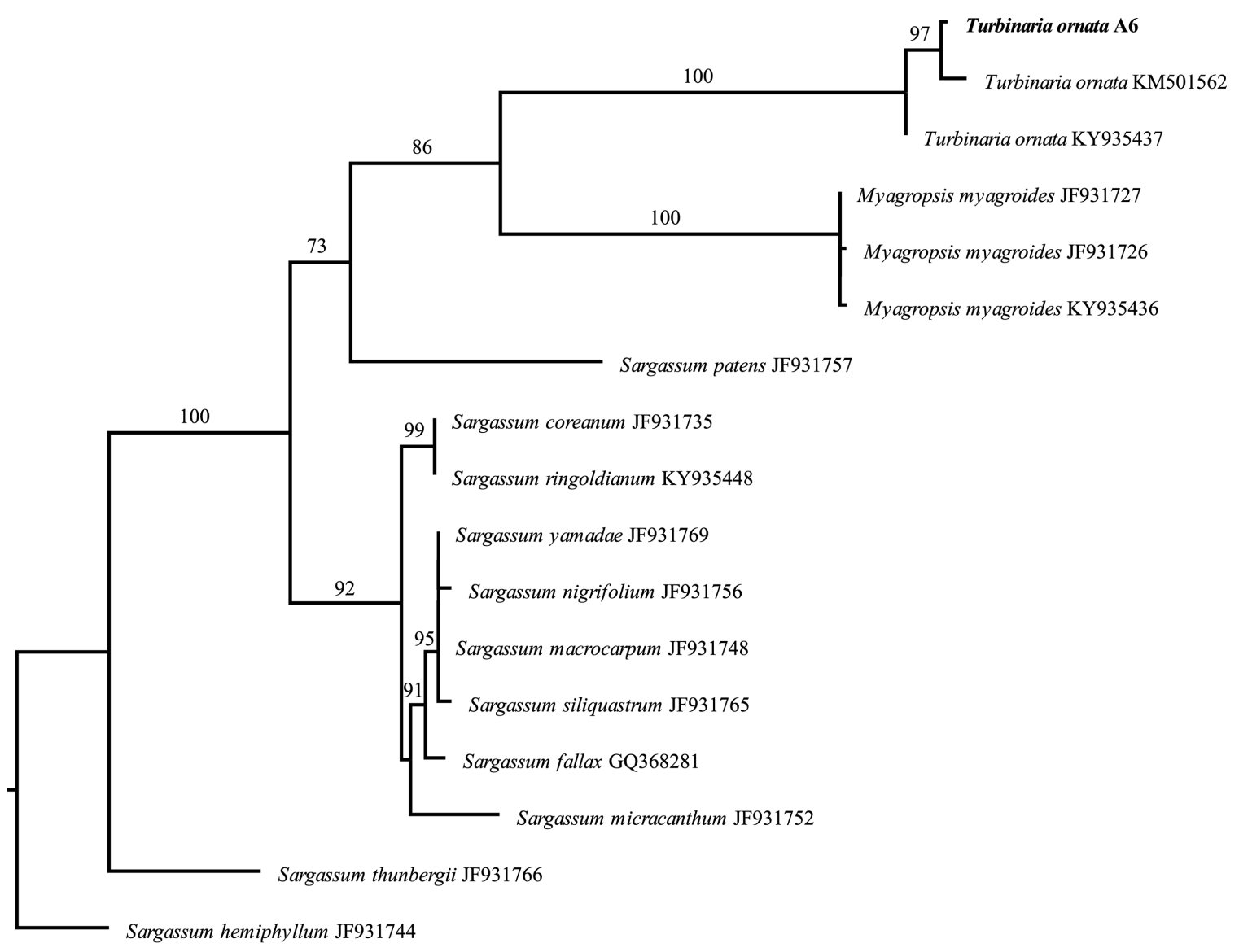

Figure 58. Maximum-likelihood tree of Turbinaria ornata using cox3 sequences. Sample A6 shown. Sargassum hemiphyllum (Turner) C.Agardh (JF931744) was used as the outgroup, but was removed for clarity. Only bootstrap support values $>50$ displayed. Scale bar $=0.04$ substitutions per site.

\section{Lobophora asiatica.}

All Lobophora spp. samples found in this study had similar external morphology with a flattened thallus attached to the substrate with rhizoids, light to dark brown pigmentation with a darker ring of apical cells on the growing margin of the thallus. Most samples were small so were preserved on microscope slides. Both samples A7 and A32 were round flattened thalli with light brown pigmentation. A noticeable pale ring and darker apical cell margin was present. Rhizoidial holdfasts anchored the specimens to aragonite substrate. A7 was collected from a Zoanthus sp. colony (Fig. 59A) whilst A32 was collected from a separate Zoanthus sp. colony (Fig. 59B). 


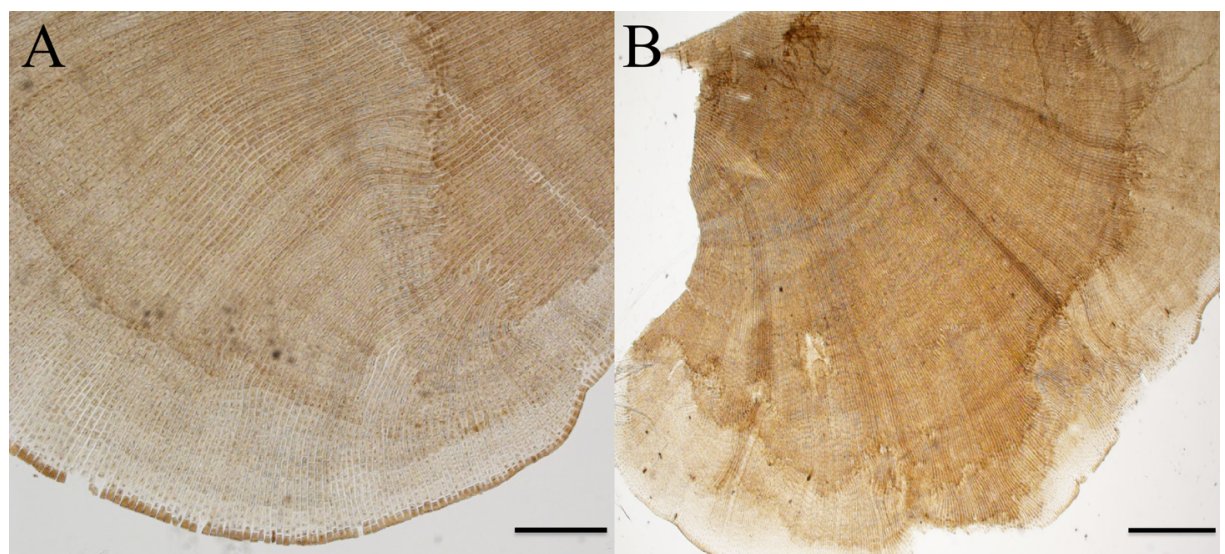

Figure 59. Samples of Lobophora asiatica Z.Sun, Ji.Tanaka \& H. Kawai photomicrographs; $\mathrm{A}=\mathrm{A} 7$, scale bar $=400 \mu \mathrm{m}, \mathrm{B}=\mathrm{A} 32$, scale bar $=1 \mathrm{~mm}$.

A maximum-likelihood tree was built using a total of 116 Lobophora spp. cox3 sequences of samples A7, A32, A46, A57, A58, A60, A61 and A108. Zonaria flabellata (JQ364040) was used as the outgroup. (Fig. S2). The following trees are subcades removed from the main Lobophora spp. tree

Samples A7 and A32 (Figs. 59, 60) group based on cox3 sequences with high bootstrap support (92\%), aligned sequences show that the samples are identical in cox3. There is a clade, containing Lobophora asiatica Z.Sun (KU353339, KU353338, AB665365), with moderate bootstrap support (77\%). A7 and A32 both are $0.31 \%$ different to Lobophora asiatica (KU353339), their closest pairwise sequence and top Blast hit. I designated samples A7 and A32 as Lobophora asiatica. 


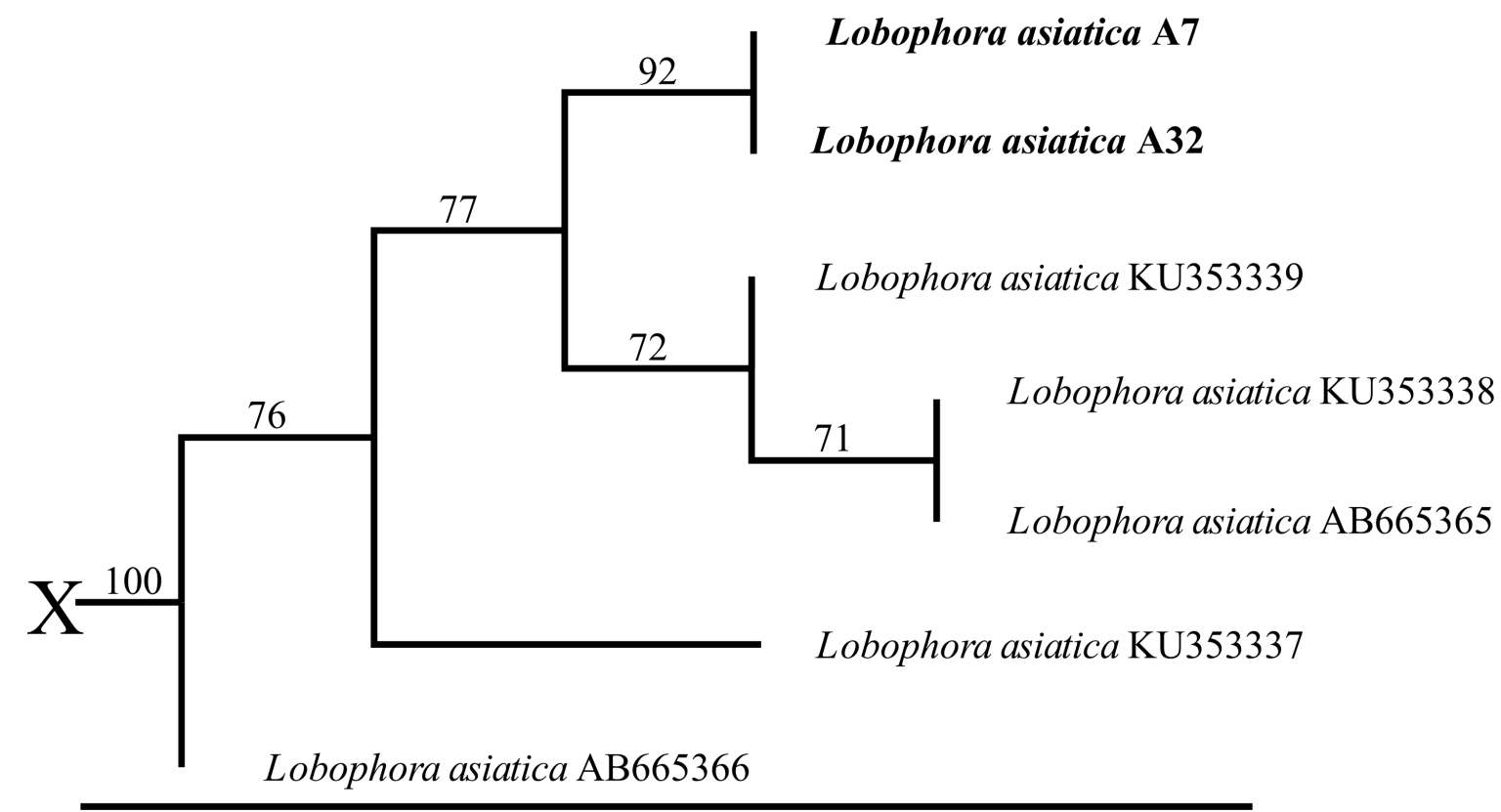

Figure 60. Subclade from the full maximum-likelihood tree of Lobophora spp. using cox3 sequences. Specimens A7 and A32 shown. Only bootstrap support values $>50$ displayed. Scale bar $=0.1$ substitutions per site. $X$ shows where the subclade was removed from the full tree.

Lobophora sp.

Sample A46 was a small thin flattened thallus, with light brown pigmentation and a dark apical margin (Fig. 61). The voucher specimen was $7 \mathrm{~mm}$ in diameter and was collected from a Caulastrea tumida (Matthai 1928) skeleton imported from Australia.

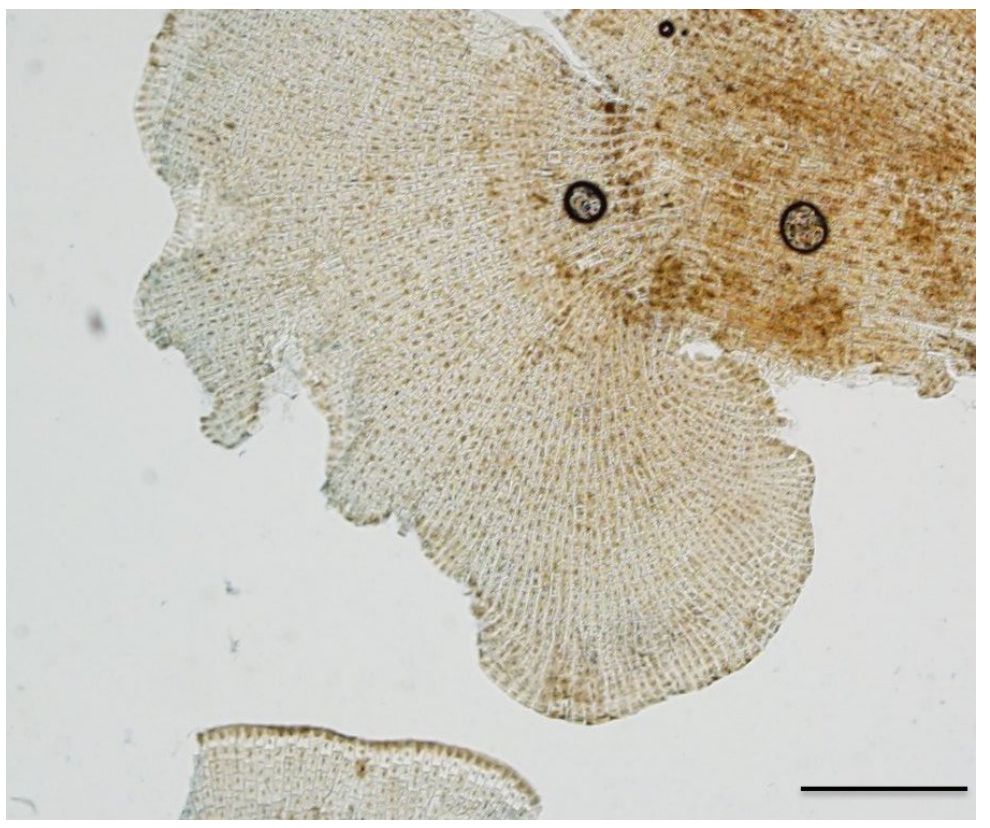

Figure 61. Sample of Lobophora sp. 24 A46. Photomicrograph. Scale bar $=400 \mu \mathrm{m}$. 
Sample A46 (Figs. 61, 62) is sister to Lobophora sp. 24 (KU353341) with high support bootstrap (95\%) and is within a clade containing Lobophora sp. 24 (KU353342) and Lobophora sp. with high bootstrap support (100\%). Sample A46 is $0.62 \%$ different to the top Blast hit Lobophora sp. 24 (KU353342) from Weizhou Island, Beigang, China, and a sequence named Lobophora sp. (AB665382), that are within the clade but not sister to A46. Sample A46 has 0.77\% pairwise difference to its sister Lobophora sp. 24 (KU353341) from Trang area, Ko Vaen, Thailand. I designated sample A46 as Lobophora sp. 24

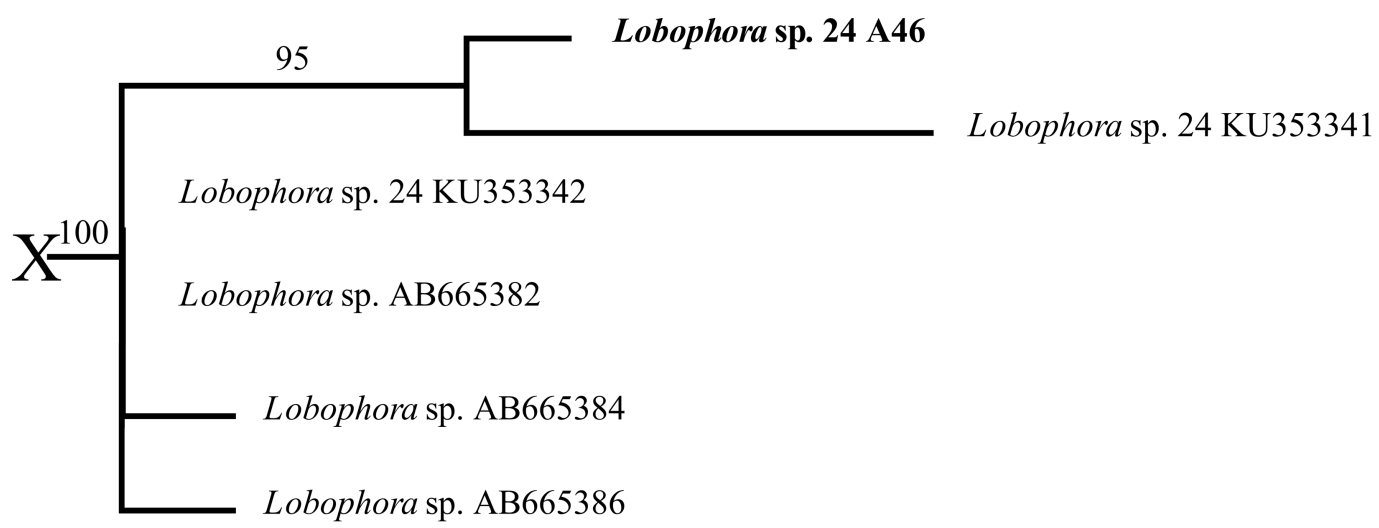

Figure 62. Subclade from the full maximum-likelihood tree of Lobophora spp. using cox3 sequences. Specimen A46 shown. Only bootstrap support values $>50$ displayed. Scale bar $=0.05$ substitutions per site. $\mathrm{X}$ shows where the subclade was removed from the full tree.

\section{Lobophora sp.}

Sample A58 was a flattened thallus with brown pigmentation (Fig. 63). The voucher specimen was a fragment from $1.5 \mathrm{~cm}$ diameter specimen collected from a Galaxea sp. colony from Australia. 


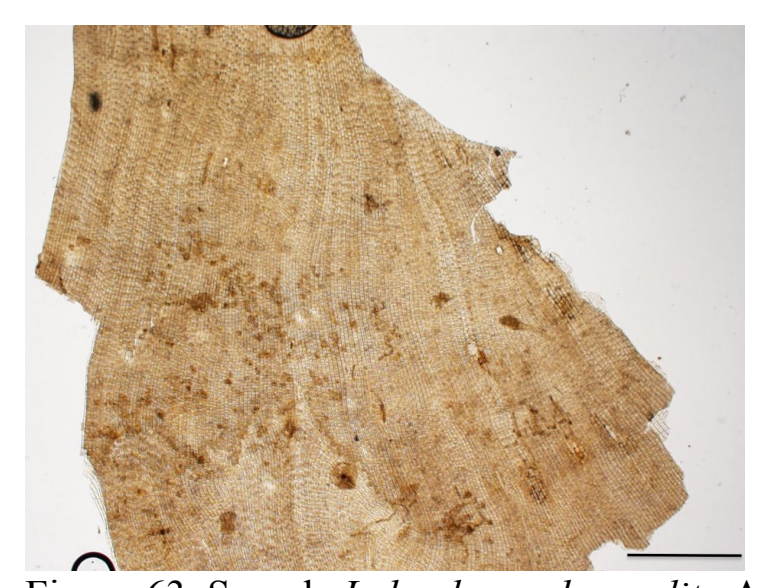

Figure 63. Sample Lobophora abscondita A58 photomicrograph. Scale bar $=1 \mathrm{~mm}$

Sample A58 (Figs. 63, 64) is within a clade containing Lobophora abscondita C.W.Vieira, Payri and De Clerck with moderate bootstrap support (83\%), the sample is 0.62\% different from Lobophora abscondita (KU353163, KM487773) its closest pairwise sequences. The top Blast hit is to Lobophora abscondita (KU353163). I designated sample A58 as Lobophora abscondita.

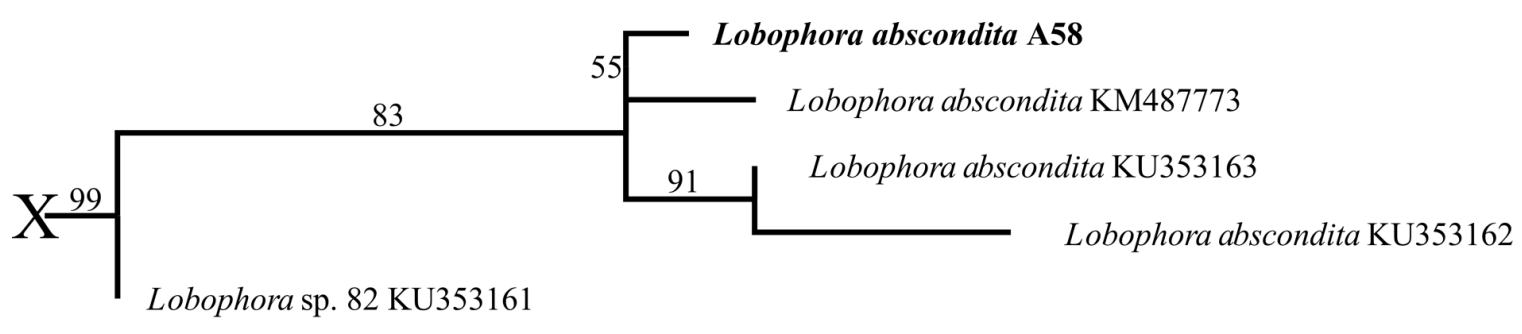

Figure 64. Subclade from the full maximum-likelihood tree of Lobophora spp. using cox3 sequences. Specimen A58 shown. Only bootstrap support values $>50$ displayed. Scale bar $=0.05$ substitutions per site. $\mathrm{X}$ shows where the subclade was removed from the full tree.

Lobophora sp1.

Sample A60 (Fig. 65) was a small plating thallus with dark brown pigmentation and a margin of apical cells. The sample was $8 \mathrm{~mm}$ in diameter when collected but fragmented when removed from its substrate (a Favia speciosa (Dana 1846) colony imported from Australia). 


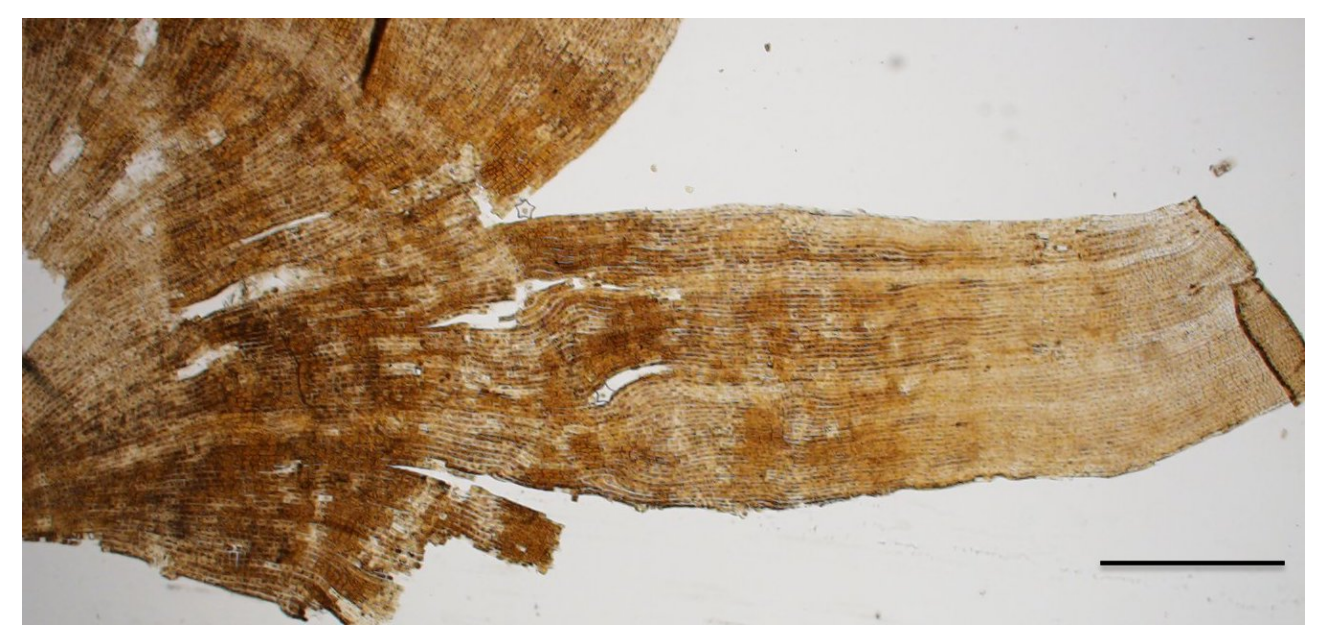

Figure 65. Sample A60 Lobophora sp. photomicrograph. Scale bar $=1 \mathrm{~mm}$

Specimen A60 (Figs. 65, 66) is sister to Lobophora sp. 14 (KU353279) with low bootstrap support (55\%), and is within a clade containing Lobophora petila C.W.Vieira, Payri and De Clerck (KU353322, KU353320, KU353319), Lobophora sp. 30 (KU353283, KU353282) and Lobophora sp. 29 (KU353290) with high support bootstrap (100\%). Sample A60 has 6.79\% pairwise difference to its sister Lobophora sp. 14 (KU353279), however A60 is closer in pairwise difference to its top Blast hit Lobophora petila (KU353322) from Papua New Guinea with 5.73\% difference. I designated sample A60 as Lobophora sp1, most similar to Lobophora petila. 


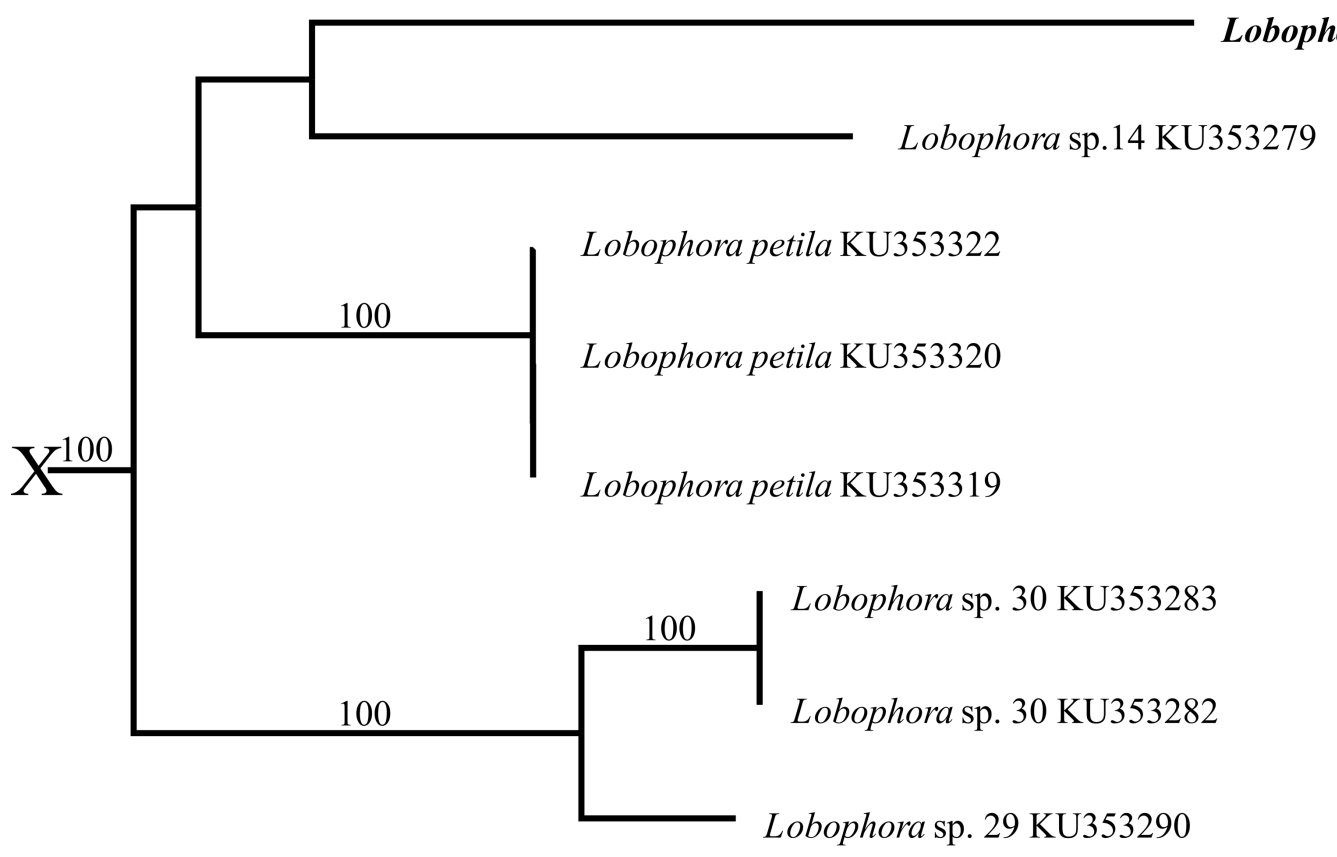

Figure 66. Subclade from the full maximum-likelihood tree of Lobophora spp. using cox3 gene sequences. Specimen A60 shown. Only bootstrap support values $>50$ displayed.

Scale bar $=0.2$ substitutions per site. $X$ shows where the subclade was removed from the full tree.

\section{Lobophora sp.}

Sample A108 was a small flattened thallus with a dark brown pigmentation, fading to a pale growth margin with dark apical cells (Fig. 67). Voucher specimen is 6 $\mathrm{mm}$ in diameter and was collected from a dead Pavona sp. skeleton from Australia.

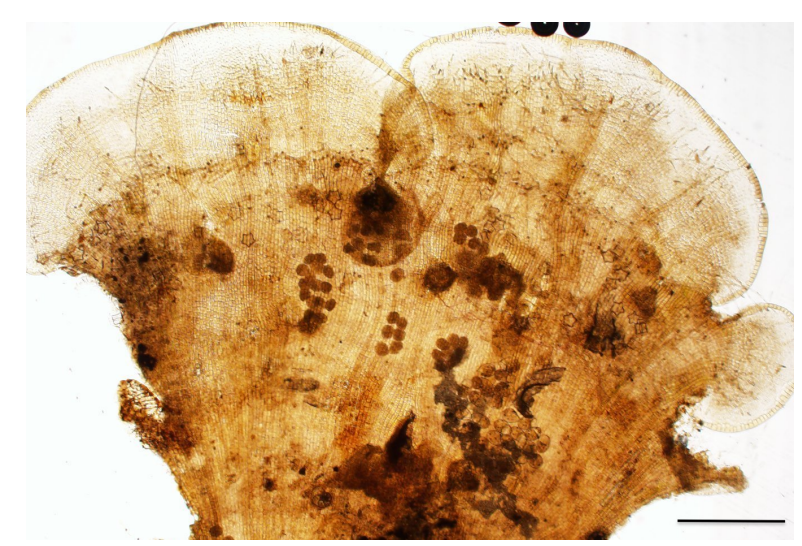

Figure 67. Sample Lobophora sp. 6 A108. Photomicrograph, scale bar $=1 \mathrm{~mm}$.

Sample A108 (Figs. 67, 68) is sister to the top Blast hit Lobophora sp. 6 (KU353257) with high support bootstrap (96\%), and is within a clade containing 
Lobophora sp. 6 (KM487892) with moderate bootstrap support (71\%). Sample A108 has $0.17 \%$ pairwise difference to the closest Genbank sequence Lobophora sp. 6

(KU353257) from Mangareva, Gambier Islands, French Polynesia. I designated specimen A108 as Lobophora sp. 6.

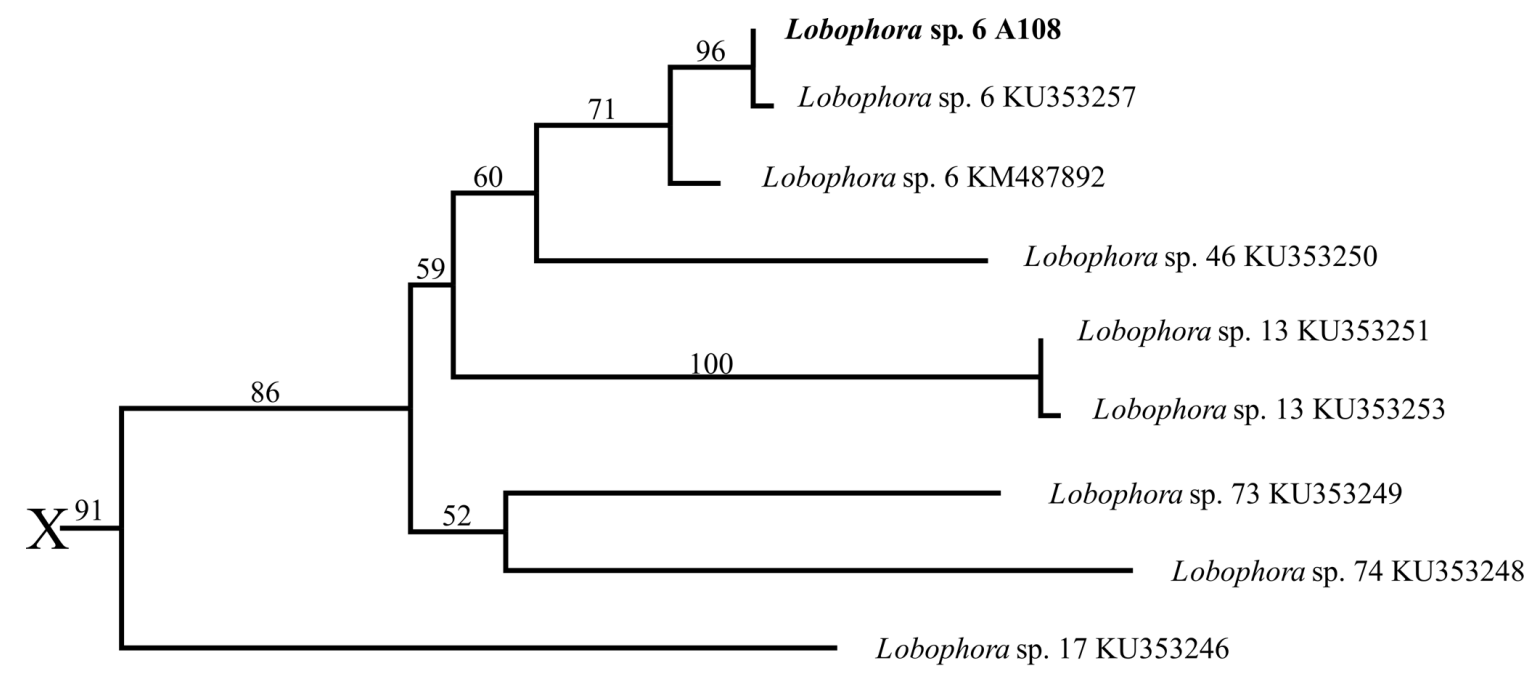

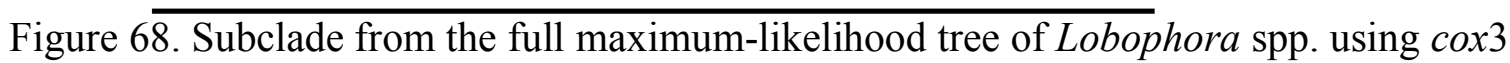
sequences. Specimen A108 shown. Only bootstrap support values $>50$ displayed. Scale bar $=0.2$ substitutions per site. $X$ shows where the subclade was removed from the full tree.

\section{Lobophora spp.}

Sample A57 is a thin flattened thallus, with light brown pigmentation and a dark apical margin. The voucher specimen was ethanol preserved and has lost pigmentation. Sample A61 is a rounded flat thallus with dark brown pigmentation. The voucher specimen had rhizoidial attachment to substrate and was collected from a Caulastrea furcata (Dana 1846) skeleton. 


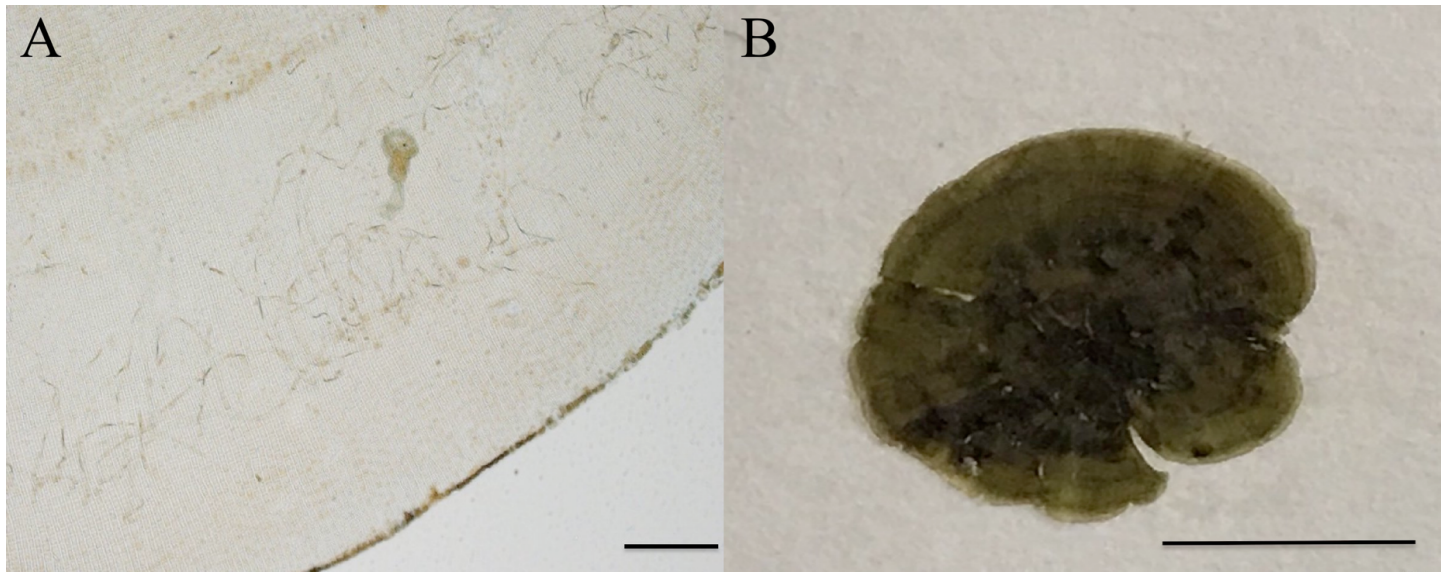

Figure 69. Samples of Lobophora spp., herbarium and photomicrographs; $A=$ photomicrograph of sample Lobophora sp. A57, scale bar $=400 \mu \mathrm{m}, \mathrm{B}=$ herbarium photo of A61, scale bar $=1 \mathrm{~cm}$.

Sample A57 (Figs. 69A, 70) is sister to Lobophora sp. 57 (KU353343), its top Blast hit with high bootstrap support (97\%), and with $2.65 \%$ pairwise difference. I designated sample A57 as Lobophora sp2 most similar to Lobophora sp. 57 (KU353343) from Mangareva, French Polynesia.

A61 (Figs. 69B, 70) is sister to its top Blast hit Lobophora sp. 10 (KU353273) from Juan de Nova Island with high support bootstrap (100\%), and has $0.47 \%$ sequence difference between the two sequences. I designated sample A61 as Lobophora sp. 10. 


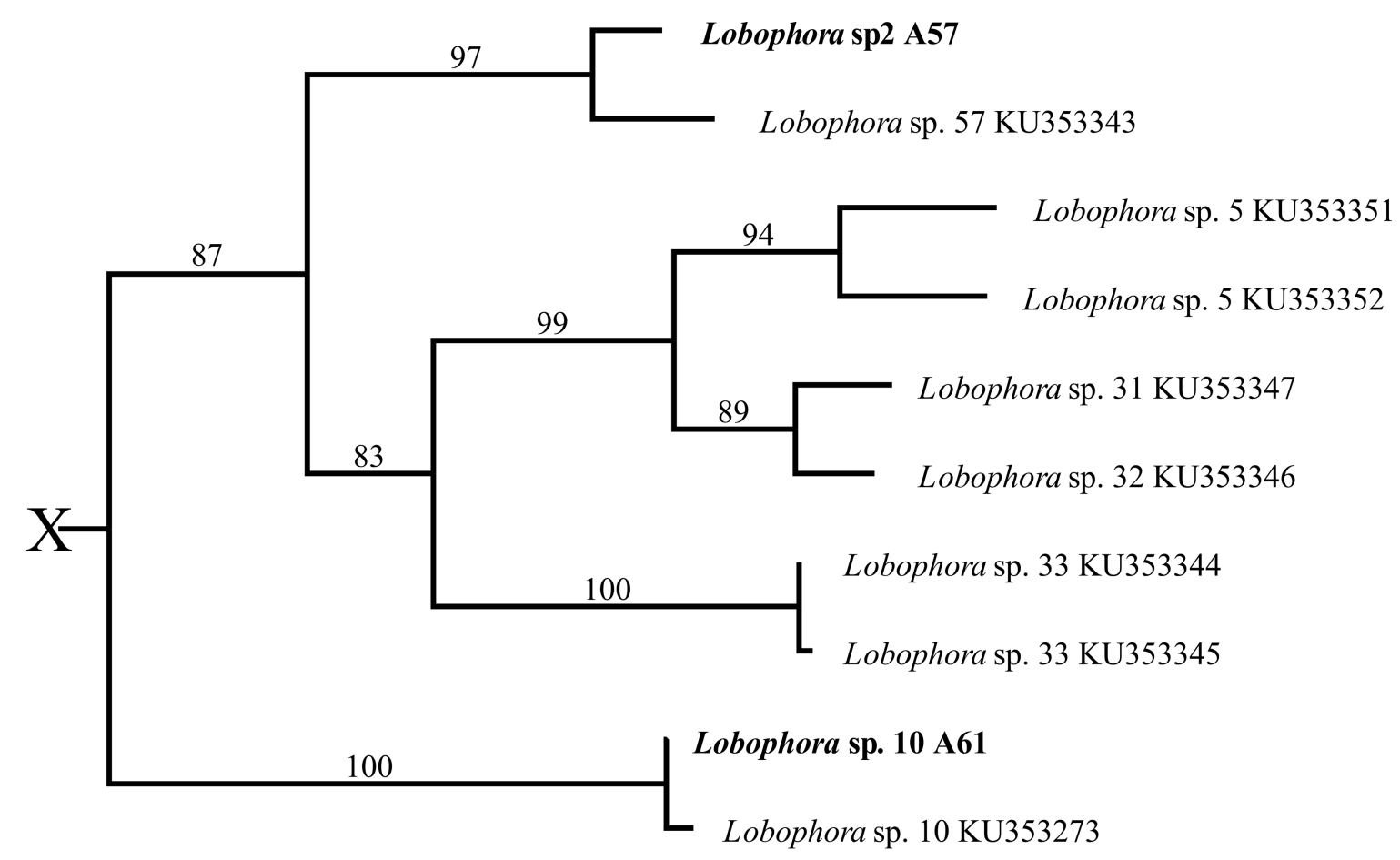

Figure 70. Subclade from the full maximum-likelihood tree of Lobophora spp. using cox3 sequences. Specimens A57 and A61 shown. Only bootstrap support values $>50$ displayed. Scale bar $=0.2$ substitutions per site. $\mathrm{X}$ shows where the subclade was removed from the full tree. 


\subsection{Physiological tolerance}

A total of 10 algal samples ( 7 red, 1 brown and 3 green) were tested.

Samples A25, A80 and A62 were maintained for 2-4 weeks in the experimental conditions to determine their survival as they appeared to remain viable and were checked for this extended period (Table 1).

All samples survived at the control temperature of $25^{\circ} \mathrm{C}$ and also at $20^{\circ} \mathrm{C}$ during the 2-4 week experimental period. All samples at the Auckland minimum SST of $14^{\circ} \mathrm{C}$ did not survive at 2-weeks or 4 weeks, except sample Chaetomorpha vieillardii (A80) that survived for 4-weeks. All samples at the Wellington minimum SST of $11^{\circ} \mathrm{C}$ did not survive at 2-weeks or 4-weeks.

Table 1. Survival of 10 macroalgae specimens. Incubation temperatures $\left( \pm 1^{\circ} \mathrm{C}\right) .-=$ no survival in all replicates, $+=100 \%$ survival in all replicates.

\begin{tabular}{|l|ll|l|l|l|}
\hline $\begin{array}{l}\text { Isolate } \\
\text { code }\end{array}$ & \multicolumn{5}{|c|}{ Species ID } \\
\hline & & $11^{\circ} \mathrm{C}$ & $14^{\circ} \mathrm{C}$ & $20^{\circ} \mathrm{C}$ & $25^{\circ} \mathrm{C}$ \\
\hline A23 & Chamaebotrys sp1. & - & - & + & + \\
\hline A106 & Ceratodictyon sp. & - & - & + & + \\
\hline A55 & Hypnea wynnei & - & - & + & + \\
\hline A56 & Hypnea sp1. & - & - & + & + \\
\hline A99 & Ceratodictyon repens & - & - & + & + \\
\hline A102 & Laurencia sp2. & - & - & + & + \\
\hline A36 & Cladophoropsis sp. & - & - & + & + \\
\hline A80 & Chaetomorpha vieillardii & - & + & + & + \\
\hline A25 & Caulerpa lentillifera & - & - & + & + \\
\hline A62 & Dictyota sp1. & - & - & + & + \\
\hline
\end{tabular}

After 1 week at $11^{\circ} \mathrm{C}$ Chaetomorpha vieillardii (A80)(Fig. 71) showed chloroplast constriction and did not recover during the experiment. Chaetomorpha vieillardii (A80) at $14^{\circ} \mathrm{C}$ treatment remained normally pigmented with no signs of bleaching or chloroplast constriction. 


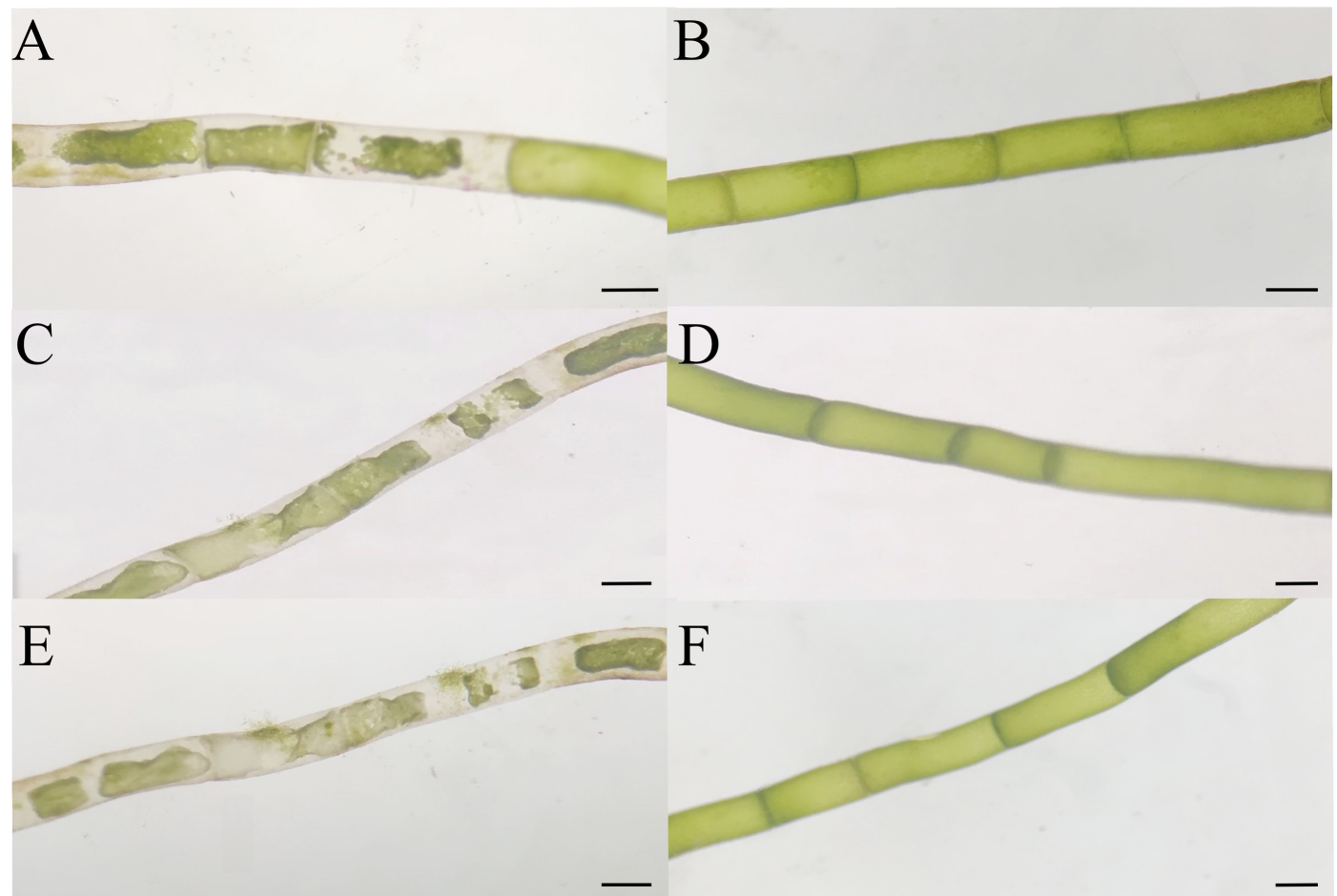

Figure 71. Micrographs of Chaetomorpha vieillardii at weekly intervals during the first 3 weeks of the 4-week physiological tolerance experiment. A, C and $\mathrm{E}$ are at $11^{\circ} \mathrm{C}$ over weeks 1,2 and 3 respectively. B, D and $\mathrm{F}$ are at $14^{\circ} \mathrm{C}$ over weeks 1,2 and 3 respectively. Scale bars $=400 \mu \mathrm{m}$. 


\subsection{Discussion}

\subsection{Algal introductions}

Our data reveals a large diversity of tropical macroalgae arriving in New Zealand through the marine aquarium trade. A total of 62 different species were identified, although some samples could only be identified to genus level. There is a high diversity of tropical macroalgae in the European marine aquarium trade (Vranken et. al. 2018), as well as in Brazil (Torrano-Silva et. al. 2013). Macroalgal diversity in New Zealand tropical marine aquaria has been understudied (Smith et. al. 2010). The presence of nonindigenous algae in aquaria poses the risk of introduction of potentially invasive species. The impacts of such species introductions can be large, including decrease in native species richness (Casas et. al. 2004), biofouling of aquaculture equipment (Fitridge et. al. 2012; Pochon et. al. 2015), and great effort and cost of eradication attempts.

The aquarium trade is a known vector of algal introductions including the introduction of the cold tolerant Caulerpa taxifolia to the Mediterranean from an aquarium at the Oceanographic Museum, Monaco (Baulch 1999; Meinesz and Hesse 1991). Other Caulerpa spp. introduced outside their native range includes $C$. chemnitzia (Sghaier et. al. 2015), C. cylindracea (Bernardeau-Esteller 2015) and C. racemosa (Nyberg and Wallentinus 2005; Piazzi et. al. 2003). Our results show that at least seven different species of Caulerpa spp. are present in New Zealand aquaria. Species found include: C. chemnitzia, C. cylindracea, C. lentillifera, C. nummularia, C. racemosa, $C$. racemosa var. macrophysa and C. sertularioides, Some Caulerpa species have caused great detriment to native ecosystems due to shading and outcompeting native species (Meinesz et. al. 2001; Piazzi et. al. 2003; Piazzi et. al. 2016). Caulerpa spp. can regenerate from small fragments and can be difficult to eradicate once established in aquaria (personal observations) and in natural ecosystems (Ceccherelli and Cinelli 1999; 
Smith and Walters 2002). A previously study has recorded the presence of a non-invasive strain of Caulerpa taxifolia and Caulerpa racemosa in the New Zealand Aquarium trade (Smith et. al. 2010).

Thau Lagoon in Hérault, France is a hotspot for introduced species (Verlaque 2001). The main vector of species introductions to Thau Lagoon was shellfish spat importation from Japan (Verlaque 2001). A few of the many introduced species are: Derbesia rhizophora Yamada, Grateloupia cf. turuturu Yamada, Laurencia okamurae Yamada, Lomentaria hakodatensis Yamada, Ulva pertusa Kjellman, Undaria pinnatifida and Valonia utricularis var. aegagropila (C.Agardh) Hauck (Verlaque 2001). Many are congeners to species found in the New Zealand aquarium trade. Our research found representatives of the genera Chondrophycus, Derbesia, Laurencia, Lomentatia, Ulva and Valonia, which are known as introduced or invasive species. Valonia spp. has been documented in overseas aquarium trades also. Valonia aegagropila is present in aquaria in Brazil (Torrano-Silva et. al. 2013) and V. macrophysa is present in European aquaria (Vranken et. al. 2018). Ulva ohnoi is an invasive green alga native to the Indo- Pacific that was introduced to the Mediterranean (Flagella et. al. 2010). Ulva ohnoi is also present in Japan where it is known for its green tide blooms (Hiraoka et. al. 2004). One specimen of Ulva ohnoi was found at a Wellington aquarium livestock retailer. Ulva ohnoi has recently been identified in temperate Australia (Kirkendale et. al. 2013), this is evidence that $U$. ohnoi can survive in lower temperatures and would likely survive in northern New Zealand if released from aquaria.

Hypnea Lamouroux is another genus of red alga that is known as an introduced species. I found 4 different species of Hypnea in the New Zealand marine aquarium trade. One species, H. wynnei, was recorded four times. Hypnea musciformis is a common species introduced to non-native locations for mariculture (Russel 1992). Hypnea cornuta 
(Kützing) J.Agardh was introduced to Taranto, Italy (Cecere et. al. 2004; Petrocelli et. al. 2015). Hypnea flexicaulis Y.Yamagishi and M.Masuda was introduced to Venice, Italy likely through a shellfish or ship vector (Wolf et. al. 2011), and has recently been identified in New Zealand (D'Archino et. al. 2015).

Our results also show the presence of at least three tropical Cladophorales in New Zealand marine aquaria. The species found are Willeella sp. and Lychaete dotyana, and two samples designated only as Lychaete sp. Both Willeella and Lychaete are recent segregates of Cladophora. The green algal genus Cladophora is known to contain some introduced species, including Cladophora ruchingeri (C.Agardh) Kützing a recent introduced green alga to the Marlborough Sounds in New Zealand (Pochon et. al. 2015). Cladophora ruchingeri is invasive and results in blooms that may clog mussel aquaculture equipment. Species of the genera Chaetomorpha and Lurbica Boedeker were also found with two occurrences of Chaetomorpha vieillardii, a potential invasive and one occurrence of Lurbica sp. The Cladophorales phylogeny shows very little genetic difference between Chaetomorpha spiralis, Chaetomorpha vieillardii and Chaetomorpha cf. inflata. Boedeker et. al. (2016) found that some sequences of $C$. vieillardii and $C$. spiralis were identical in LSU, and it appears that $C$. spiralis and C. vieillardii may be the same or similar species. Sequences labeled as different species in Genbank with little to no pairwise difference makes it difficult to distinguish between species.

The genus Chaetomorpha contains bloom-forming strains such as the invasive strain of Chaetomorpha viellardii present in Guam (University of Guam https://cnasre.uog.edu/wp-content/uploads/2018/09/IInvasive_speciesGuam.pdf). C. vieillardii has been found for sale in the European aquarium trade along with another unidentified species (Vranken et. al. 2018). Another species of Chaetomorpha, C. spiralis has been found in aquaria in Brazil (Torrano-Silva et. al. 2013). With knowledge on the potential 
for invasiveness in Chaetomorpha spp., methods of safe disposal and implications of unsafe disposal have been discussed (Odom et. al. 2014). It has been found that Chaetomorpha sp. can survive extended periods $\sim 6$ days in freshwater, this means that algal tissue or fragments in aquarium water may survive and reach the ocean if disposed of into storm water drains (Odom et. al. 2014).

\subsection{Temperature tolerance}

Our temperature tolerance testing of 10 algal samples to New Zealand minimum winter temperatures in Auckland and Wellington found that only a Chaetomorpha vieillardii sample (A80) tolerated $14^{\circ} \mathrm{C}$. Cold tolerance in Chaetomorpha spp. has previously been shown in Chaetomorpha crassa (C.Agardh) Kützing, Chaetomorpha moniligera Kjellman and Chaetomorpha spiralis with growth at $15^{\circ} \mathrm{C}$ and little growth at $10^{\circ} \mathrm{C}$, although it is still able to survive (Gao et. al. 2018.). Growth at low temperatures makes Chaetomorpha spp. a potential risk to New Zealand if released. Other studies have found cold tolerance in tropical algae. The Australian native and invasive Caulerpa taxifolia can survive and grow at temperature between $15-18^{\circ} \mathrm{C}$ (Galasby and Gibson 2007). The Mediterranean ecotype of the tropical alga Valonia utricularis has a lower temperature limit of $5^{\circ} \mathrm{C}$ (Eggert et. al. 2003) making it capable of surviving across most of New Zealand. We cannot confirm that $V$. utricularis is present in the New Zealand aquarium trade as we did not find this particular species, however three species of Valonia were found. Marine aquaria are often kept at lower temperatures than the temperature of natural reefs, potentially selecting for more cold tolerant strains as has been suggested with the invasive strain of Caulerpa taxifolia (Meinesz and Boudouresque 1996). 


\subsection{Implications of propagule pressure on algal introductions}

Propagule pressure is an important determinant of introduction success (Duggan et. al. 2006). There are two aspects of propagule pressure; the initial number of individuals introduced and the frequency of subsequent immigration (Drake and Lodge 2004). The more individuals introduced (larger propagule numbers) the higher the probability of establishment. An example of propagule pressure in a natural system is the large populations of the introduced alga Undaria pinnatifida in marinas, facilitating its spillover to nearby rocky reef ecosystems (Epstein and Smale 2018). Our results have found multiple occurrences of certain species, such as Hypnea wynnei. Two of the three Valonia species were also found occurred multiple times, with two occurrences of $V$. ventricosa and three occurrences of $V$. macrophysa. Species in the Peyssonneliaceae were found multiple times, four samples of Peyssonnelia spp. and two samples of Ramicrusta sp. This indicates, if this reflects the importation incidence, that propagule pressure from these species, or other species, in New Zealand aquaria could increase the risks of release and establishment. The importation of corals into New Zealand occurs on a regular basis. The main importer in New Zealand currently imports new stock about once a month. A single importation may contain over 100 coral specimens (personal observation). The frequency of coral arrivals and the large number of corals in the importation increases the chance of encountering a variety of algae species and multiple individuals of the same species. We cannot conclude whether the multiple occurrences of certain species of macroalgae that we found in our study are due to multiple introductions to New Zealand or the reproduction of macroalgae in the importers aquaria and their subsequent recruitment to different coral rocks. Our results do indicate that some species are 
prevalent in aquaria and so propagule pressure, and chance release, from personal aquaria and retail is still a concern.

\subsection{Algal reproduction in aquaria}

The ability of an alga to survive and reproduce in aquaria could have implications for its potential as an introduced species. Many algae have the capability to regenerate from small fragments or holdfasts making eradication from an aquarium difficult. Hypnea wynnei had cystocarps in the sample we collected, showing the potential for sexual reproduction. Sexual reproduction allows for increased genetic variation in populations. Sexual reproduction increases the spread of the alga between hobbyists' tanks, through spores, when trading corals and fish. The fluctuation in water parameters that occurs in aquaria may provide selection pressures, selecting for weedy strains and developing strains more tolerant to changes in environmental conditions and potentially being more invasive. Sexual recombination produces offspring with more resistance to certain environmental conditions. This has been shown in sexual strains of Escherichia coli Migula (Peabody et. al. 2017) and yeast (Goddard et. al. 2005). Another example of sexual recombination under selection producing a more tolerant strain is a 39 -fold increase in imidacloprid resistance occurring in the ladybeetle Propylaea japonica (Thunberg) after 20 generations under laboratory experiments (Tang et. al. 2015).

\subsection{Polymorphic species}

Polymorphic species have always been an issue for taxonomists. Many algal genera contain polymorphic species; examples include Sargassum (Mattio and Payri 2011), Halimeda (Verbruggen et. al. 2005), and Caulerpa (Gacia et. al. 1996; Sauvage et. al. 2013). Caulerpa, for instance, can be highly polymorphic, making species assignment 
problematic (Belton et. al. 2014; De Senerpont Domis et. al. 2003). One of our samples Caulerpa nummularia (A111) had flattened mushroom shaped ramuli when grown under low intensity lighting in a refugium, once relocated to higher light the morphology of new ramuli changed to flattened with serrations. Molecular barcoding therefore is an effective way of distinguishing species that have overlap in morphological boundaries (Verbruggen 2014; Verbruggen et. al. 2007; 2005). There are cases where molecular identification is difficult or not possible, such as old herbarium specimens where the DNA is degraded, or the specimen is heavily degraded (e.g., with formalin fixation, or rotting) before being dried (Särkinen et. al. 2012). One example of this is a sample of Caulerpa sertularioides donated as a live specimen from a hobbyist in Auckland. Amplification of the tufA gene was not successful due to decay in transport. Morphological identification however identified it as most like $C$. sertularioides.

\subsection{Cryptic diversity}

Cryptic diversity is another issue that makes morphological identification difficult due to little or no morphological differences between some species (Cianciola et. al. 2010). Two brown algal genera well-known for cryptic diversity are Lobophora (Schultz et. al. 2015; Vieira et. al. (2014), and Padina (Ni-Ni Win et. al. 2011). A recent study identified many genetically distinct entities of Lobophora spp. in New Caledonia that can be considered species (Vieira et. al. 2014). Our results show that at least seven different species of Lobophora have been found in the New Zealand aquarium trade. One species Lobophora asiatica was found twice, showing repeat occurrence. There were a few samples that may be new species of Lobophora. Sample A60 designated by us as Lobophora sp1 and sample A57, designated as Lobophora sp2, are different from any other Lobophora species sequenced so far. Red algal genera containing cryptic diversity 
have also been found by molecular barcoding (e.g., Cianciola et. al. 2010; Zuccarello et. al. 2005; Zuccarello and West 2002; 2003). This shows the importance of molecular identification in accurately identifying algae.

Cryptic diversity needs to be taken into account to correctly determine the diversity of algae entering the New Zealand marine aquarium trade as more species may be entering than recognized by morphological characters. Cryptic species can have different physiological tolerance characteristics as shown by Muangmai (2015) in a study of temperature tolerance of cryptic species of Bostrychia intricata (Bory) Montagne. Cryptic species can also have different habitat preferences. For example, on the rocky shores of Moa Point, Wellington, Bostrychia intricata cryptic species N2 had strict preference to wave exposed locations whereas cryptic species N4 was found in mostly wave protected locations, cryptic species N5 was found in both exposed and sheltered locations in almost equal proportions (Muangmai 2015). Another example of cryptic species having differing physiological tolerance is the temporal replacement of two cryptic species of Dictyota sp. at the Canary Islands (Tronholm et. al. 2010). Dictyota dichotoma (Hudson) J.V.Lamouroux was previously thought to be present year round but D. dichotoma reaches highest abundance at temperatures of $21^{\circ} \mathrm{C}-22^{\circ} \mathrm{C}$ in summer then dies back to resting stages in winter, being replaced by Dictyota cymatophila (A.Tronholm) M.Sanson and J.Afonso-Carrillo. The cryptic species D. cymatophila reaches highest abundance during winter temperatures of $17^{\circ} \mathrm{C}-18^{\circ} \mathrm{C}$, dying back to resting stages in summer. The variation in temperature tolerance between cryptic species suggests that some cryptic species of algae will be better suited to New Zealand winter minimum SST than others and therefore pose more of a biosecurity risk than others. 


\subsection{Utility of BLAST and Maximum-Likelihood Phylogenies in molecular identification}

We used Blast searching along with maximum-likelihood (ML) phylogenies to determine the identity of our samples. The Blast search tool on the NCBI website is useful for assisting molecular taxonomy. Blast compares the sequence in question with those in specific databases and reports those with regions of high similarity to the entire sequence. Blast is biased to finding the most similar sequence over the longest stretch of nucleotides. BLAST will score a longer but lower similarity match higher than a shorter, more similar match (Duffy et. al. 2010). This can however lead to misidentification of the closest match in some cases. You can determine if the sequence is of the target gene from Blast search results and in many cases determine the genus and species that the sample was from by the top Blast hits (Dudu et. al. 2016; Kool et. al. 2012).

Maximum-likelihood (ML) is a robust method of building a phylogeny and provides statistical support for the final tree (Yuan et. al. 2013). ML allows for the selection of substitution models to take into account varying rates of evolution across both lineages and sites (Felsenstein 1981; Fukami-Kobayashi and Tateno 1991; Hamberg 2011). The main pitfall of ML is that it is computationally costly (Hamberg 2011)

Molecular identification from Blast searches alone can be done but is not necessarily as accurate as building a ML phylogeny from aligned sequences (Ross et. al. 2008). Other studies have utilized both Blast and ML analysis to effectively identify species (Freshwater et. al. 2017; Raja et. al. 2017). From our results, the top Blast hit and sequences of high identity to the samples were often in the ML clade containing our samples, and in many cases the top Blast hit was sister to our sample. There were cases however where the Blast top hit and the sequence sister to our sample in the phylogeny were different. For example, Sample A8 (Chondrophycus sp3) had a larger pairwise 
different in cox 1 to its sister Chondrophycus sp. (HQ423056) and less of a pairwise difference in $\operatorname{cox} 1$ to its top Blast hit Chondrophycus sp. (KX258815).

\subsection{Limitations of public database sequences}

Some taxonomic groups are understudied therefore have inadequate sequences available in Genbank for effective species level identification of new isolates. This is apparent in the ITS1 gene in fungi (Nilsson et. al. 2005; 2006) and the $r b c \mathrm{~L}$ gene in diatoms (An et. al. 2018). Some of our samples, that could only be identified to genus level, had large pairwise distances to the closest Genbank sequences. Sample A2, a branching red alga, is $13.4 \%$ different in cox 1 to its closest Genbank sequence, Lomentaria divaricata from Canada. Sample A4 had 9.24 \% pairwise difference in cox 1 to Halopeltis willisii from North Carolina USA, another temperate species. Samples A2 and A4 are either of described species that have not been sequenced using cox 1 , or may be undescribed species. An inability to identify a sample to species level has implications for determining if the alga is an introduced species or not, and its physiological tolerance characteristics.

The names of sequences in Genbank must be taken with some caution. For example, within our Caulerpa serrulata clade there is a sequence named Caulerpa cupressoides (DQ652336) from Indonesia; this may have been a misidentification as it has $0.5 \%$ pairwise difference in tufA, or 3 base pairs, to our sample (A45) and other samples of Caulerpa serrulata. Another limitation of Genbank sequences is that some sequences have not been updated when species or generic names change. An example of sequences that have not been updated to the most recent names were the five sequences named Caulerpa racemosa f. macrophysa an entity that has been synonomised with Caulerpa racemosa var. macrophysa (Taylor 1928). Also, sequences were named 
Caulerpa peltata an entity that has been synonymized with Caulerpa chemnitzia (Belton et. al. 2014). Our Cladophorales tree (Fig. 31) also has species present that have been formally renamed but not updated on Genbank by the collector. Cladophora montagneana has been renamed Willeella brachyclados (Whynne 2016).

Misidentification and incorrect naming of sequences submitted to Genbank is a common occurrence, $65 \%$ of over 600 Ganoderma spp. fungal sequences surveyed were misidentified or ambiguously labeled (Jargalmaa et. al. 2017). The LSU alignment for samples A36 and A43 had sequences with the same pairwise difference to samples named as different species, making it difficult to identify our samples to species level. The LSU gene may also not be highly variable in Siphonocladales preventing us from delimiting species, however, using LSU effectively identified three species of Valonia a genus within the Siphonocladales. Other studies have found LSU as an effective marker for identifying species within the Siphonocladales (Leliaert et. al. 2009; 2007). Another possibility is that the samples uploaded to Genbank were not all correctly identified before being deposited.

Not all sequences on Genbank have been given species names, many sequences have only been designated with a genus name or even just a family name, for example (Chondrophycus sp., Laurencia sp.) or order names (Gigartinales sp., Rhodymeniales sp.). This can make it difficult in determining the species that you have sequenced especially if there are few sequences of close identity to the query sequence in Genbank. Species level identification is important to determine whether an isolate is from an introduced species or an already naturalized species. 


\subsection{Regulation and prevention of algal introductions from aquaria}

This study found a large diversity of tropical macroalgae entering the New Zealand Aquarium trade on imported corals. Some of the species identified have proven invasive overseas, such as Caulerpa racemosa and Caulerpa cylindracea with detrimental effects to native ecosystems when released (Piazzi et. al. 2016; 2003). These findings have important implications for New Zealand biosecurity, as there are currently no measures in place to prevent invasive algal species from passing through quarantine undetected as spores or germlings to reach hobbyists aquariums. Strict monitoring of marine aquarium livestock during quarantine and a longer quarantine period would be needed to detect the presence of exotic macroalgal hitchhikers. The outlawing of the sale of certain algal genera has been suggested (Smith et. al. 2010), to prevent the spread of invasive algae between aquaria, for example, Caulerpa spp. in Florida (Stam et. al. 2006). A ban of the sale of nine Caulerpa spp. is in place in California USA, with a genus wide ban in San Diego (Diaz et. al. 2012). Banning sale and the propagation of potentially invasive algae will need enforcement and education for it to succeed. The ban on Caulerpa spp. sales in California USA has so far not ended the sale of the banned Caulerpa species due to lack of enforcement (Diaz et. al. 2012). On the other hand, many tropical algae cannot tolerate present day winter minimum SST in Auckland and Wellington, New Zealand.

Many aquarists are unaware of the impacts of releasing aquarium specimens or wastewater into natural environments (Martin and Coetzee 2011; Duggan et. al. 2006; Gertzen et. al. 2008). The finding of an alga with cold tolerance to Auckland minimum winter temperature is alarming as northern New Zealand has a sea surface temperature that rarely declines to or below $14^{\circ} \mathrm{C}$. As this strain of Chaetomorpha vieillardii can tolerate low temperature, grows into very large unattached balls and can reproduce from 
single cell fragments (Odom et. al. 2014), it is a biosecurity threat in northern New Zealand. The general public needs to have access to information on the proper disposal of unwanted aquarium livestock and wastewater to reduce the risk of an unintentional release of an alga into New Zealand ecosystems.

\subsection{Limitations and future research}

\subsection{Limitations}

Having access to more marine aquarium livestock importers and a larger sample size of coral rocks would have been useful. We did however find a very large diversity of species 62 from our 78 samples. Not knowing the collection location of many of the marine invertebrates that our samples came from was a limitation of our study. Collection location information would have been useful for determining habitat compatibility to New Zealand, as some of the corals kept in New Zealand aquaria are in fact subtropical and I assume that the associated algae will also have low temperature tolerance.

Some of our samples, predominately red algae, could only be identified to genus using the genes chosen for this study. Perhaps a different DNA sequence may have had better resolution or have more sequences available, cox 1 versus $r b c \mathrm{~L}$ for example. In the majority of cases a single gene was effective. Use of a second gene may have increased resolution in identifying some species. Use of two genes was implemented in Boedeker et. al. (2017) and Pochon et. al. (2015) for more accurate species delimitation. Use of multiple genes relies on the algal group being well studied with good sequence data for each gene, which is not the case for many algal groups. 


\subsection{Future research}

Testing a broader range of physiological tolerance parameters, for example, salinity and $\mathrm{pH}$ might be helpful in determining introduction risk of tropical algae to different habitats within New Zealand. Our study used survival/death of tropical macroalgal samples at different temperatures as a measure of introduction risk. Survival/death was adequate for this study but doesn't take into account whether or not the surviving algae are stressed. Some studies used Pulse Amplitude Modulation (PAM) Flurometery to determine photosynthetic yield as a measure of stress in algae (Flagella et. al. 2008; Graiff et. al. 2015). Use of PAM in future physiological tolerance experiments will help in determining stress and potential acclimatization in the algae tested.

A survey, along with dried sample collection for DNA extraction, for algae kept in aquarium refugia or reported by marine aquarium hobbyists would be useful, to better gauge the prevalence of certain algal genera across the entire New Zealand aquarium trade. Sampling from coral rocks that have been freshly imported into New Zealand and are in quarantine would be useful as we will achieve a larger sample size and collect algae that may otherwise detach, be removed or die back while in quarantine. We will also be able to observe if there are signs that the algae are reproducing during quarantine, rather than in the importation step of custody. 


\section{References}

Adams, J., Fang, W., Callaway, R., Cipollini, D., and Newell, E. (2009) A crosscontinental test of the Enemy Release Hypothesis: leaf herbivory on Acer platanoides (L.) is three times lower in North America than in its native Europe. Biological Invasions 11, 1005-1016.

An, S.M., Choi, D.H., Lee, H., Lee, J.H., and Noh, J.H. (2018) Next-generation sequencing reveals the diversity of benthic diatoms in tidal flats. Algae 33, 167-180.

Aguilar-Rosas, R., Aguilar-Rosas, L.E., Ávila-Serrano, G., and Marcos-Ramírez, R. (2004) First record of Undaria pinnatifida (Harvey) Suringar (Laminariales, Phaeophyta) on the Pacific coast of Mexico. Botanica Marina 47, 255-258.

Alpert, P. (2006) The advantages and disadvantages of being introduced. Biological Invasions 8, 1523-1534.

Baulch, H. (1999) Escaped aquarium plant plagues Mediterranean ecosystem. Alternatives Journal 25, 3.

Belton, G.S., Reine, W.F.P.H., Huisman, J.M., Draisma, S.G.A., and D. Gurgel, C.F. (2014) Resolving phenotypic plasticity and species designation in the morphologically challenging Caulerpa racemosa - peltata complex (Chlorophyta, Caulerpaceae. Journal of Phycology 50, 32-54.

Bernardeau-Esteller, J., Ruiz, J.M., Tomas, F., Sandoval-Gil, J.M., and Marín-Guirao, L. (2015) Photoacclimation of Caulerpa cylindracea: Light as a limiting factor in the invasion of native Mediterranean seagrass meadows. Journal of Experimental Marine Biology and Ecology 465, 130-141.

Boedeker, C., Leliaert, F., and Zuccarello, G. (2016) Molecular phylogeny of the Cladophoraceae (Cladophorales, Ulvophyceae), with the resurrection of Acrocladus Nägeli and Willeella Børgesen, and the description of Lurbica gen. nov. and Pseudorhizoclonium gen. nov. Journal of Phycology 52, 905-928.

Boedeker, C., Leliaert, F., and Zuccarello, G. (2017) Genetic diversity and biogeography in Chaetomorpha melagonium (Ulvophyceae, Cladophorales) based on internal transcribed spacer (ITS rDNA) sequences. Botanica Marina 60, 319-325.

Bøhn, T., Amundsen, P.-A., and Sparrow, A. (2008) Competitive exclusion after invasion? Biological Invasions 10, 359-368.

Bollen, M., Pilditch, C., Battershill, C., and Bischof, K. (2016) Salinity and temperature tolerance of the invasive alga Undaria pinnatifida and native New Zealand kelps: Implications for competition. International Journal on Life in Oceans and Coastal Waters 163, 1-14. 
Briggs, J. (2012) Marine species invasions in estuaries and harbors. Marine Ecology Progress Series 449, 297-302.

Britton-Simmons, K.H., and Abbott, K.C. (2008) Short and long term effects of disturbance and propagule pressure on a biological invasion. Journal of Ecology 96, 6877 .

Broom, J.E., Nelson, W.A., Yarish, C., Jones, W.A., Aguilar Rosas, R., and Aguilar Rosas, L.E. (2002) A reassessment of the taxonomic status of Porphyra suborbiculata, Porphyra carolinensis and Porphyra lilliputiana (Bangiales, Rhodophyta) based on molecular and morphological data. European Journal of Phycology 37, 227-235.

Buchanan, J., and Zuccarello, G.C. (2018). Utility of molecular-assisted alpha taxonomy of the genus Cystophora (Fucales, Phaeophyceae) from New Zealand and Australia. Phycologia 57, 374-384.

Burfeind, D.D., and Udy, J.W. (2009) The effects of light and nutrients on Caulerpa taxifolia and seagrass interactions in Moreton Bay, Australia. Aquatic Botany 90, 105-109.

Burfeind, D.D., O’brien, K.R., and Udy, J.W. (2013) Water temperature and benthic light levels drive horizontal expansion of Caulerpa taxifolia in native and invasive locations. Marine Ecology Progress Series 472, 61-72.

Calado, R., and Chapman, P.M. (2006) Aquarium species: Deadly invaders. 52, 599-601.

Campbell, M.L., King, S., Heppenstall, L.D., van Gool, E., Martin, R., and Hewitt, C.L. (2017) Aquaculture and urban marine structures facilitate native and non-indigenous species transfer through generation and accumulation of marine debris. Marine Pollution Bulletin 123, 303-312

Campbell, S.J., and Burridge, T.R. (1998) Occurrence of Undaria pinnatifida (Phaeophyta : Laminariales) in Port Phillip Bay, Victoria, Australia. Marine and Freshwater Research 49, 379-381.

Carpelan, L.H. (1964) Effects of Salinity on Algal Distribution. Ecology 45, 70-77.

Casas, G., Scrosati, R., and Luz Piriz, M. (2004) The Invasive Kelp Undaria Pinnatifida (Phaeophyceae, Laminariales) Reduces Native Seaweed Diversity in Nuevo Gulf (Patagonia, Argentina). Biological Invasions 6, 411-416.

Castric-Fey, A., Girard, A., and L'hardy-Halos, M.T. (1993) Distribution of Undaria pinnatifida (Phaeophyceae : Laminariales) on the Coast of St. Malo (Brittany, France). Botanica Marina 36, 351-358.

Ceccherelli, G., and Cinelli, F. (1997) Short-term effects of nutrient enrichment of the sediment and interactions between the seagrass Cymodocea nodosa and the introduced green alga Caulerpa taxifolia in a Mediterranean bay. Journal of Experimental Marine Biology and Ecology 217, 165-177. 
Ceccherelli, G., and Cinelli, F. (1999) Effects of Posidonia oceanica canopy on Caulerpa taxifolia size in a north-western Mediterranean bay. Journal of Experimental Marine Biology and Ecology 240, 19-36.

Ceccherelli, G., and Cinelli, F. (1999) The role of vegetative fragmentation in dispersal of the invasive alga Caulerpa taxifolia in the Mediterranean. Marine Ecology Progress Series 182, 299-303

Ceccherelli, G., Piazzi, L., and Balata, D. (2002) Spread of introduced Caulerpa species in macroalgal habitats. Journal of Experimental Marine Biology and Ecology 280, 1-11.

Cecere, E., Petrocelli, A., and Verlaque, M. (2004) Morphology and vegetative reproduction of the introduced species Hypnea cornuta (Rhodophyta, Gigartinales) in the Mar Piccolo of Taranto (Italy), Mediterranean Sea. Botanica Marina 47, 381-388.

Chapman, P.M. (1995) Ecotoxicology and pollution, key issues. Marine Pollution Bulletin 31, 167-177.

Chernomor, O., von Haeseler, A., and Minh, B.Q. (2016) Terrace Aware Data Structure for Phylogenomic Inference from Supermatrices. Systematic Biology 65, 997-1008.

Cianciola E.N., Popolizio T.R., Schneider C.W., and Lane C.E. (2010) Using MolecularAssisted Alpha Taxonomy to Better Understand Red Algal Biodiversity in Bermuda. Diversity 2, 946-958.

Conklin, E., and Smith, J. (2005) Abundance and Spread of the Invasive Red Algae, Kappaphycus spp., in Kanere? Vol. 49. pp. 215-225. ean bayntal Assessment of Management Options. Biological Invasions 7, 1029-1039.

Coppejans, E., Leliaert, F., Verbruggen, H., Prathep, A., and De Clerck, O. (2011) Rhipidosiphon lewmanomontiae sp. nov. (Bryopsidales, Chlorophyta), a calcified udoteacean alga from the central Indo-Pacific based on morphological and molecular investigations. Phycologia 50, 403-412.

Cox, E. (1999) Rate of spread of introduced rhodophytes Kappaphycus alvarezii, Kappaphycus striatum, and Gracilaria salicornia and their current distributions in Kane'ohe Bay, O'ahu, Hawaii. Pacific Science 53, 232.

Davis, A., Benkendorff, K., and Ward, D. (2005) Responses of common SE Australian herbivores to three suspected invasive Caulerpa spp. International Journal on Life in Oceans and Coastal Waters 146, 859-868.

D'Archino, R., Nelson, W., Yang, M., and Kim, M.S. (2015) New record of Hypnea flexicaulis in New Zealand and description of Calliblepharis psammophilus sp nov. Bot. Marina 58, 485-497.

De Clerck, O., Guiry, M.D., Leliaert, F., Samyn, Y., and Verbruggen, H. (2013) Algal taxonomy: a road to nowhere? 49, 215-225. 
De Leaniz, C.G., Gajardo, G., and Consuegra, S. (2010) From Best to Pest: changing perspectives on the impact of exotic salmonids in the southern hemisphere. Systematics and Biodiversity 8, 447-459.

Derraik, J., and Phillips, S. (2010) Online trade poses a threat to biosecurity in New Zealand. Biological Invasions 12, 1477-1480.

De senerpont domis, L., Famà, P., Bartlett, A., Prud'homme van reine, W., Espinosa, C., and Trono, G. (2003) Defining taxon boundaries in members of the morphologically and genetically plastic genus Caulerpa (Caulerpales, Chlorophyta) 1. Journal of Phycology 39, 1019-1037.

Diaz, S., Smith, J., Zaleski, R., and Murray, S. (2012) Effectiveness of the California State Ban on the Sale of Caulerpa Species in Aquarium Retail Stores in Southern California. Environmental Management 50, 89-96.

Dromgoole, F.I. (1975) Occurrence of Codium fragile subspecies tomentosoides in New Zealand waters. New Zealand Journal of Marine and Freshwater Research 9, 257-264.

Dudu, A., Barba Lata, T., Popa, G.O., Georgescu, S.E., and Costache, M. (2016) Advantages and limitations of DNA barcoding in identifying commercially-exploited fish species. Scientific Papers: Animal Science and Biotechnologies 49, 45-49.

Duffy, S., and Seah, Y. (2010) 98\% identical, 100\% wrong: Percent nucleotide identity can lead plant virus epidemiology astray. Philosophical Transactions of the Royal Society $B, \mathbf{3 6 5}, 1891-1897$.

Duggan, I., Rixon, C., and MacIsaac, H. (2006) Popularity and Propagule Pressure: Determinants of Introduction and Establishment of Aquarium Fish. Biological Invasions 8, 377-382.

Eggert, A., Burger, E.M., and Breeman, A.M. (2003) Ecotypic Differentiation in Thermal Traits in the Tropical to Warm-Temperate Green Macrophyte Valonia utricularis. Botanica Marina 46, 69-81.

Eggert, A., Van Hasselt, P.R., and Breeman, A.M. (2003a) Chilling-induced photoinhibition in nine isolates of Valonia utricularis (Chlorophyta) from different climate regions. Journal of Plant Physiology 160, 881-891.

Eggert, A., Van Hasselt, P.R., and Breeman, A.M. (2003b) Differences in thermal acclimation of chloroplast functioning in two ecotypes of Valonia utricularis (Chlorophyta). European Journal of Phycology 38, 123-131.

Eldredge, L.G., and Carlton, J.T. (2002) Hawaiian Marine Bioinvasions: a preliminary assessment. Pacific Science 56, 211-212.

Epstein, G., and Smale, D. (2018) Environmental and ecological factors influencing the spillover of the non-native kelp, Undaria pinnatifida, from marinas into natural rocky reef communities. Biological Invasions 20, 1049-1072. 
Erickson, A., Paul, V., Alstyne, K., and Kwiatkowski, L. (2006) Palatability of Macroalgae that Use Different Types of Chemical Defenses. Journal of Chemical Ecology 32, 1883-1895.

Eschtruth, A.K., and Battles, J.J. (2011) The importance of quantifying propagule pressure to understand invasion: an examination of riparian forest invasibility. Ecology 92, 1314-1322.

Fabricius, K.E. (2005) Effects of terrestrial runoff on the ecology of corals and coral reefs: review and synthesis. Marine Pollution Bulletin 50, 125-146.

Fama, P., Wysor, B., Kooistra, W.H.C.F., and Zuccarello, G.C. (2002) Molecular phylogeny of the genus Caulerpa (Caulerpales, Chlorophyta) inferred from chloroplast tufa gene1. Journal of Phycology 38, 1040-1050.

Felsenstein, J. (1981) "Evolutionary trees from DNA sequences: a maximum likelihood approach". Journal of Molecular Evolution 17, 368-376

Filloramo, G.V., and Saunders, G.W. (2016) Molecular-assisted alpha taxonomy of the genus Rhodymenia (Rhodymeniaceae, Rhodymeniales) from Australia reveals overlooked species diversity. European Journal of Phycology 51, 354-367.

Fitridge, I., Dempster, T., Guenther, J., and De Nys, R. (2012) The impact and control of biofouling in marine aquaculture: a review. Biofouling 28, 649-669.

Flagella, M., Andreakis, N., Hiraoka, M., Verlaque, M., and Buia, M. (2010) Identification of cryptic Ulva species (Chlorophyta, Ulvales) transported by ballast water. Journal of Biological Research. Scientific Annals of the School of Biology 13, 47-57.

Flagella, M., Lorenti, M., and Buia, M. (2008) Temperature response in a shallow-water Mediterranean population of Caulerpa racemosa var. cylindracea (Caulerpales, Chlorophyta), and a possible strategy of season anticipation. Botanica Marina 51, 278284.

Floc'h, J.-Y., Pajot, R., and Mouret, V. (1996) Undaria pinnatifida (Laminariales, Phaeophyta) 12 years after its introduction into the Atlantic Ocean. The International Journal of Aquatic Sciences 326, 217-222.

Forrest, B.M., and Blakemore, K.A. (2006) Evaluation of treatments to reduce the spread of a marine plant pest with aquaculture transfers. Aquaculture 257, 333-345.

Freshwater, D.W., Idol, J., Parham, S., Fernandez-García, C., León, N., Gabrielson, P., and Wysor, B. (2017) Molecular Assisted Identification Reveals Hidden Red Algae Diversity from the Burica Peninsula, Pacific Panama. Diversity 9, 19.

Freshwater, D.W., and Rueness, J. (1994) "Phylogenetic Relationships of Some European Gelidium (Gelidiales, Rhodophyta) Species, Based on $r b c \mathrm{~L}$ nucleotide Sequence Analysis." Phycologia 33, 187-94. 
Fukami-Kobayashi, K., and Tateno, Y. (1991) Robustness of maximum likelihood tree estimation against different patterns of base substitutions. Journal of Molecular Evolution 32, 79-91.

Gacia, E., Littler, M.M., and Littler, D.S. (1996) The relationships between morphology and photosynthetic parameters within the polymorphic genus Caulerpa. Journal of Experimental Marine Biology and Ecology 204, 209-224.

Gao, X., Endo, H., and Agatsuma, Y. (2018) Comparative study on the physiological differences between three Chaetomorpha species from Japan in preparation for cultivation. Journal of Applied Phycology 30, 1167-1174.

Geller, J.B., and Carlton, J.T. (1993) Ecological roulette: the global transport of nonindigenous marine organisms. (release of ship ballast water threatens ecosystem in ports). Science 261, 78.

Gertzen, E., Familiar, O., and Leung, B. (2008) Quantifying invasion pathways: fish introductions from the aquarium trade. Canadian Journal of Fisheries and Aquatic Sciences 65, 1265-1273.

Glasby, T. (2013) Caulerpa taxifolia in seagrass meadows: killer or opportunistic weed? Biological Invasions 15, 1017-1035.

Glasby, T., and Gibson, P. (2007) Limited evidence for increased cold- tolerance of invasive versus native Caulerpa taxifolia. International Journal on Life in Oceans and Coastal Waters 152, 255-263.

Goddard, Matthew R., Godfray, H. Charles J., and Burt, Austin. (2005). Sex increases the efficacy of natural selection in experimental yeast populations. Nature 434, 636-640.

Goff, L.J., and Moon, D.A. (1993) PCR amplification of nuclear and plastid genes from algal herbariums specimens and algal spores1. Journal of Phycology 29, 381-384.

Goldson, S., Bourdôt, G., Brockerhoff, E., Byrom, A., Clout, M., McGlone, M., Nelson, W., Popay, A., Suckling, D., and Templeton, M. (2015) New Zealand pest management: current and future challenges. Journal of the Royal Socciety of New Zealand 45, 1-28.

Gozlan, R.E., Britton, J.R., Cowx, I., and Copp, G.H. (2010) Current knowledge on nonnative freshwater fish introductions. Journal of Fish Biology 76, 751-786.

Graiff, A., Liesner, D., Karsten, U., and Bartsch, I. (2015) Temperature tolerance of western Baltic Sea Fucus vesiculosus - growth, photosynthesis and survival. Journal of Experimental Marine Biology and Ecology 471, 8-16.

Halling, C., Wikström, S., Lillieskoöld-Sjöö, G., Mörk, E., Lundsør, E., and Zuccarello, G. (2013) Introduction of Asian strains and low genetic variation in farmed seaweeds: indications for new management practices. Journal of Applied Phycology 25, 89-95. 
Hamberg, E.H. (2011) Inferring Phylogenies Using Evolutionary Algorithms: A maximum likelihood approach for constructing phylogenetic trees from molecular data. (Norwegian University of Science and Technology)

Hanelt, D., Melchersmann, B., Wiencke, C., and Nultsch, W. (1997) Effects of high light stress on photosynthesis of polar macroalgae in relation to depth distribution. Marine Ecology Progress Series 149, 255-266.

Hasegawa, M., Kishino, H., Yano, T. (1985) "Dating of human-ape splitting by a molecular clock of mitochondrial DNA". Journal of Molecular Evolution 22, 160-174

Hassouna, N., Michot, B., and Bachellerie, J.P. (1984) The complete nucleotide sequence of mouse 28S rRNA gene. Implications for the process of size increase of the large subunit rRNA in higher eukaryotes. Nucleic acids research 12, 3563-3583.

Heike, Z., Patric, B., Joern, F., Erik, W., and Henrik Von, W. (2014) The Human Release Hypothesis for biological invasions: human activity as a determinant of the abundance of invasive plant species [v1; ref status: indexed, http://f1000r.es/33c]. F1000Research 3.

Hermoso, V., Clavero, M., Blanco - Garrido, F., and Prenda, J. (2011) Invasive species and habitat degradation in Iberian streams: an analysis of their role in freshwater fish diversity loss. Ecological Applications 21, 175-188.

Higgins, S.I., and Richardson, D.M. (2014) Invasive plants have broader physiological niches. Proceedings of the National Academy of Sciences of the United States of America 111, 10610.

Hiraoka, M., Shimada, S., Uenosono, M. and Masuda, M. (2004) A new green-tideforming alga, Ulva ohnoi Hiraoka \& Shimada sp. nov. (Ulvales, Ulvophyceae) from Japan. Phycological Research 52, 17-29

James, K., and Shears, N. (2016) Proliferation of the invasive kelp Undaria pinnatifida at aquaculture sites promotes spread to coastal reefs. International Journal on Life in Oceans and Coastal Waters 163, 1-12.

James, T.M., Marie, V., Mark, J., and Frédérique, V. (2016) Abundance and recruitment data for Undaria pinnatifida in Brest harbour, France: Model versus field results. Data in Brief 7, 540-545.

Jargalmaa, S., Eimes, J.A., Park, M.S., Park, J.Y., Oh, S.-Y., and Lim, Y.W. (2017) Taxonomic evaluation of selected Ganoderma species and database sequence validation. PeerJ 5, e3596.

Johnson, M., Zaretskaya, I., Raytselis, Y., Merezhuk, Y., McGinnis, S., and Madden, T.L. (2008) NCBI BLAST: a better web interface. Nucleic acids research 36, W5-W9.

Jukes T.H., and Cantor, C.R. (1969). Evolution of Protein Molecules. New York: Academic Press 21-132. 
Kalyaanamoorthy, S., Minh, B.Q., Wong, T.K.F., von Haeseler, A., and Jermiin, L.S. (2017) ModelFinder: fast model selection for accurate phylogenetic estimates.(Report). Nature Methods 14, 587.

Kimura, M. (1981) Estimation of Evolutionary Distances between Homologous Nucleotide Sequences. Proceedings of the National Academy of Sciences of the United States of America 78, 454-458.

Kirkendale, L., Saunders, G.W. and Winberg, P. (2013) A molecular survey of Ulva (Chlorophyta) in temperate Australia reveals enhanced levels of cosmopolitanism. Journal of Phycology 49, 69-81.

Komatsu, T., Ishikawa, T., Yamaguchi, N., Hori, Y., and Ohba, H. (2003) But next time?: Unsuccessful Establishment of the Mediterranean Strain of the Green Seaweed Caulerpa taxifolia in the Sea of Japan. Biological Invasions 5, 275-278.

Komatsu, T., Meinesz, A., and Buckles, D. (1997) Temperature and light responses of alga Caulerpa taxifolia introduced into the Mediterranean Sea. Marine Ecology Progress Series 146, 145-153.

Kool, A., De-Boer, H.J., Krüger, Å., Rydberg, A., Abbad, A., Björk, L., and Martin, G. (2012) Molecular identification of commercialized medicinal plants in southern Morocco. PLoS ONE 7, e39459.

Lagourgue, L., Puillandre, N., and Payri, C.E. (2018) Exploring the Udoteaceae diversity (Bryopsidales, Chlorophyta) in the Caribbean region based on molecular and morphological data. Molecular Phylogenetics and Evolution 127, 758-769.

Lapointe, B.E., and Bedford, B.J. (2010) Ecology and nutrition of invasive Caulerpa brachypus f. parvifolia blooms on coral reefs off southeast Florida, U.S.A. Harmful Algae 9, 1-12.

Lee, H., and Kim, M. (2015) Species delimitation in the green algal genus Codium (Bryopsidales) from Korea using DNA barcoding. Acta Oceanologica Sinica 34, 114 124.

Leliaert, F., De Clerck, O., Verbruggen, H., Boedeker, C., and Coppejans, E. (2007) Molecular phylogeny of the Siphonocladales (Chlorophyta: Cladophorophyceae). Molecular Phylogenetics and Evolution 44, 1237-1256.

Leliaert, F., Verbruggen, H., Wysor, B., and Clerck, O.D. (2009) DNA taxonomy in morphologically plastic taxa: Algorithmic species delimitation in the Boodlea complex (Chlorophyta: Cladophorales). Molecular Phylogenetics and Evolution 53, 122-133.

Liu, H., and Stiling, P. (2006) Testing the enemy release hypothesis: a review and metaanalysis. Biological Invasions 8, 1535-1545.

Levin, P.S., Coyer, J.A., Petrik, R., and Good, T.P., (2002) Community-wide effects of nonindigenous species on temperate rocky reefs. Ecology 83, 3182-3193 
Maf Biosecurity New Zealand, i.b., and New Zealand. Ministry for Primary Industries, i.b. (2010) Import health standard : dried and preserved plant material, and fresh plant material for testing, analysis or research : MPI.Standard.Plant material. (Wellington, New Zealand : Ministry for Primary Industries)

Maf, Biosecurity, New Zealand, and New Zealand. Ministry for Primary Industries (2009a) Import health standard for ornamental fish and marine invertebrates from all countries. (Wellington, N.Z. : MAF Biosecurity New Zealand: Wellington, N.Z.)

Maf, Biosecurity, New Zealand, and New Zealand. Ministry for Primary Industries (2009b) Import risk analysis tropical, subtropical and temperate freshwater and marine ornamental fish and marine molluscs and crustaceans : review of submissions and supplementary risk analysis. In ROS supplementary RA ornamental fish. (Wellington, N.Z. : MAF Biosecurity New Zealand: Wellington, N.Z.)

Manoylov, K.M. (2014) Taxonomic identification of algae (morphological and molecular): species concepts, methodologies, and their implications for ecological bioassessment 50, 409-424.

Martin, G., and Coetzee, J. (2011) Pet stores, aquarists and the internet trade as modes of introduction and spread of invasive macrophytes in South Africa. Water S.A 37, 371380 .

Mattio, L., and Payri, C. (2011) 190 Years of Sargassum Taxonomy, Facing the Advent of DNA Phylogenies. Botanical Review 77, 31-70.

Meinesz, A., Boudouresque, C.F. (1996) On the origin of Caulerpa taxifolia in the Mediterranean Sea. Cr Acad Sci III-Vie 319, 603-613

Meinesz, A., Belsher, T., Thibaut, T., Antolic, B., Mustapha, K., Boudouresque, C.-F., Chiaverini, D., Cinelli, F., Cottalorda, J.-M., Djellouli, A., El Abed, A., Orestano, C., Grau, A., Ivesa, L., Jaklin, A., Langar, H., Massuti-Pascual, E., Peirano, A., Tunesi, L., de Vaugelas, J., Zavodnik, N., and Zuljevic, A. (2001) The Introduced Green Alga Caulerpa Taxifolia Continues to Spread in the Mediterranean. Biological Invasions $\mathbf{3}$, 201-210.

Meinesz, A., and Hesse, B. (1991) Introduction of the tropical alga Caulerpa taxifolia and its invasion of the Northwestern Mediterranean. Oceanologica acta. Paris 14, 415426.

Meretta, P., Matula, C., and Casas, G. (2012) Occurrence of the alien kelp Undaria pinnatifida ( Laminariales, Phaeophyceae) in Mar del Plata, Argentina. BioInvasions Records 1, 59-63.

Mineur, F., Johnson, M., Maggs, C., and Stegenga, H. (2007) Hull fouling on commercial ships as a vector of macroalgal introduction. International Journal on Life in Oceans and Coastal Waters 151, 1299-1307.

Moutou, F., and Pastoret, P.P. (2010) Defining an invasive species. Revue scientifique et technique (International Office of Epizootics) 29, 37. 
Muangmai, N. (2015) Unraveling the secret life of cryptic algal species: evolution, phylogeography and eco-physiology of the red alga, Bostrychia intricata. (Victoria University of Wellington)

Nguyen, L.-T., Schmidt, H., Von Haeseler, A., and Minh, B. (2015) IQ-TREE: A Fast and Effective Stochastic Algorithm for Estimating Maximum-Likelihood Phylogenies. Molecular Biology and Evolution 32, 268.

Nilsson, R., Ryberg, M., Kristiansson, E., Abarenkov, K., Larsson, K., Kõljalg, U., and Fairhead, C. (2006) Taxonomic Reliability of DNA Sequences in Public Sequence Databases: A Fungal Perspective (Taxonomy and DNA Databases). PLoS ONE 1, E59.

Nilsson, R., Kristiansson, E., Ryberg, M., and Larsson, K. (2005) Approaching the taxonomic affiliation of unidentified sequences in public databases - an example from the mycorrhizal fungi. BMC Bioinformatics 6, 178.

Ni - Ni - Win, Hanyuda, T., Arai, S., Uchimura, M., Prathep, A., Draisma, S.G.A., Phang, S.M., Abbott, I.A., Millar, A.J.K., and Kawai, H. (2011) a taxonomic study of the genus Padina (Dictyotales, Phaeophyceae) including the descriptions of four new species from Japan, Hawaii and the Andaman sea. Journal of Phycology 47, 1193.

Nyberg, C., and Wallentinus, I. (2005) Can species traits be used to predict marine macroalgal introductions? Biological Invasions 7, 265-279.

Occhipinti-Ambrogi, A. (2007) Global change and marine communities: Alien species and climate change. Marine Pollution Bulletin 55, 342-352.

Odom, R., and Walters, L. (2014) A safe alternative to invasive Caulerpa taxifolia (Chlorophtya)? Assessing aquarium-release invasion potential of aquarium strains of the macroalgal genus Chaetomorpha (Chlorophyta). Biological Invasions 16, 1589-1597.

Orth, R.J., Carruthers, T.J.B., Dennison, W.C., Duarte, C.M., Fourqurean, J.W., Heck, K.L., Hughes, A.R., Kendrick, G.A., Kenworthy, W.J., Olyarnik, S., Short, F.T., Waycott, M., and Williams, S.L. (2006) A Global Crisis for Seagrass Ecosystems. BioScience 56, 987-996.

Padilla, D.K., and Williams, S.L. (2004a) Beyond ballast water: aquarium and ornamental trades as sources of invasive species in aquatic ecosystems. Frontiers in Ecology and the Environment 2, 131-138.

Padilla, D.K., and Williams, S.L. (2004b) Beyond ballast water: aquarium and ornamental trades as sources of invasive species in aquatic ecosystems. Frontiers in Ecology and the Environment 2, 131-138.

Peabody V, G., Li, H., and Kao, K. (2017). Sexual recombination and increased mutation rate expedite evolution of Escherichia coli in varied fitness landscapes. Nature 8, 2112.

Pereira, D.T., Simioni, C., Filipin, E.P., Bouvie, F., Ramlov, F., Maraschin, M., Bouzon, Z.L., and Schmidt, É.C. (2017) Effects of salinity on the physiology of the red macroalga, Acanthophora spicifera (Rhodophyta, Ceramiales). Acta Botanica Brasilica 31, 555-565. 
Pergent-Martini, C., Dumay, O., Boudouresque, C.-F., Pergent, G., and WyllieEcheverria, S. (2008) Competition between the invasive macrophyte Caulerpa taxifolia and the seagrass Posidonia oceanica: contrasting strategies. BMC Ecology 8, 20.

Peteiro, C., Sánchez, N., and Martínez, B. (2016) Mariculture of the Asian kelp Undaria pinnatifida and the native kelp Saccharina latissima along the Atlantic coast of Southern Europe: An overview. Algal Research 15, 9-23.

Petrocelli, A., Cecere, E., Portacci, G., Micheli, C., De Cecco, L., Martini, S., and Borfecchia, F. (2015) preliminary mapping of the alien seaweed Hypnea cornuta (Rhodophyta, Gigartinales) in the Mar Piccolo of Taranto (Southern Italy, Mediterranean sea). Biologia Marina Mediterranea 22, 44-45.

Piazzi L, Balata D, Cecchi E, Cinelli F. (2003). Co-occurrence of Caulerpa taxifolia and C. racemosa in the Mediterranean Sea: Interspecific interactions and influence on native macroalgal assemblages. Cryptogamie, Algologie 24, 233-43

Piazzi, L., Balata, D., Bulleri, F., Gennaro, P., and Ceccherelli, G. (2016) The invasion of Caulerpa cylindracea in the Mediterranean: the known, the unknown and the knowable. Marine Biology 163, 1-14.

Piazzi, L., and Ceccherelli, G. (2002) Effects of competition between two introduced Caulerpa. Marine Ecology Progress Series 225, 189-195.

Pickering, T.D., Skelton, P., and Sulu, R.J. (2007) Intentional introductions of commercially harvested alien seaweeds. Botanica Marina 50, 338-350.

Pochon, X., Atalah, J., Wood, S., Hopkins, G., Watts, A., and Boedeker, C. (2015) Cladophora ruchingeri (C. Agardh) Kutzing, 1845 (Cladophorales, Chlorophyta): a new biofouling pest of green-lipped mussel Perna canaliculus (Gmelin, 1791) farms in New Zealand. Aquatic Invasions 10, 123-133.

Quinn, T., Nielsen, J., Gan, C., Unwin, M., Wilmot, R., Guthrie, C., and Utter, F. (1996) Origin and genetic structure of chinook salmon, Oncorhynchus tshawytscha, transplanted from California to New Zealand: Allozyme and mtDNA evidence. Fishery Bulletin 94, 506-521.

Race, M. (1982) Competitive displacement and predation between introduced and native mud snails. Oecologia 54, 337-347.

Raja, H., Miller, A., Pearce, C., and Oberlies, N. (2017) Fungal Identification Using Molecular Tools: A Primer for the Natural Products Research Community. Journal of Natural Products 80, 756-770.

Richardson, D.M., and Pyšek, P. (2006) Plant invasions: merging the concepts of species invasiveness and community invasibility. Progress in Physical Geography 30, 409-431.

Ross, H.A., Murugan, S., Sibon Li, W.L., and Hedin, M. (2008) Testing the Reliability of Genetic Methods of Species Identification via Simulation. Systematic Biology 57, 216230. 
Rowe, D. (2007) Exotic fish introductions and the decline of water clarity in small North Island, New Zealand lakes: a multi-species problem. The International Journal of Aquatic Sciences 583, 345-358.

Ruiz, G.M., Fofonoff, P., Hines, A.H., and Grosholz, E.D. (1999) Non-indigenous species as stressors in estuarine and marine communities: assessing invasion impacts and interactions.(The Effects of Multiple Stressors on Freshwater and Marine Ecosystems). Limnology and Oceanography 44, 950.

Sanderson, J.C. (1990) A Preliminary Survey of the Distribution of the Introduced Macroalga, Undaria pinnatifida (Harvey) Suringer on the East Coast of Tasmania, Australia. Botanica Marina 33, 153-158.

Särkinen, T., Staats, M., Richardson, J.E., Cowan, R.S., and Bakker, F.T. (2012) How to Open the Treasure Chest? Optimising DNA Extraction from Herbarium Specimens.(Research Article)(Report). PLoS ONE 7, e43808.

Saunders, G.W. (2005) Applying DNA Barcoding to Red Macroalgae: A Preliminary Appraisal Holds Promise for Future Applications. Philosophical Transactions: Biological Sciences 360, 1879-1888.

Sauvage, T., Payri, C., Draisma, S.G.A., Prud'homme van Reine, W.F., Verbruggen, H., Belton, G.S., Gurgel, F.D., Gabriel, D., Sherwood, A.R. and Fredericq, S. (2013) Molecular diversity of the Caulerpa racemosa-Caulerpa peltata complex (Caulerpaceae, Bryopsidales) in New Caledonia, with new Australasian records for C. racemosa var. cylindracea. Phycologia 52, 6-13.

Schneider, C., and Wynne, M. (2007) A synoptic review of the classification of red algal genera a half century after Kylin's a Die Gattungen der Rhodophyceena. Botanica Marina 50, 197-249.

Schultz, N.E., Lane, C.E., Le Gall, L., Gey, D., Bigney, A.R., De Reviers, B., Rousseau, F., and Schneider, C.W. (2015) A barcode analysis of the genus Lobophora (Dictyotales, Phaeophyceae) in the western Atlantic Ocean with four novel species and the epitypification of L. variegata (J.V. Lamouroux) E.C. Oliveira. European Journal of Phycology 50, 1-20.

Schwartz, N., Rohde, S., Hiromori, S., and Schupp, P. (2016a) Understanding the invasion success of Sargassum muticum : herbivore preferences for native and invasive Sargassum spp. International Journal on Life in Oceans and Coastal Waters 163, 1-13.

Schwartz, N., Rohde, S., Hiromori, S., and Schupp, P. (2016b) Understanding the invasion success of Sargassum muticum : herbivore preferences for native and invasive Sargassum spp. International Journal on Life in Oceans and Coastal Waters 163, 1-13.

Sghaier, Y.R., Zakhama-Sraieb, R., Mouelhi, S., Vazquez, M., Valle, C., Ramos-Espla, A.A., Astier, J.M., Verlaque, M., and Charfi-Cheikhrouha, F. (2015) Review of alien marine macrophytes in Tunisia. Mediterranean Marine Science 17, 109-123. 
Smith, C.M., and Walters, L.J. (1999) Fragmentation as a Strategy for Caulerpa Species: Fates of Fragments and Implications for Management of an Invasive Weed. Marine Ecology 20, 307-319.

Smith, K.F., Acosta, H., Broom, J.E., and Rhodes, L.L. (2010) Identification of nonindigenous marine macroalgae from New Zealand aquaria outlets. New Zealand Journal of Marine and Freshwater Research 44, 29-37.

Smith, K.F., and Lester, P.J. (2007) Trophic interactions promote dominance by cyanobacteria (Anabaena spp.) in the pelagic zone of lower Karori reservoir, Wellington, New Zealand. New Zealand Journal of Marine and Freshwater Research 41, 143-155.

Stachowicz, J.J., Terwin, J.R., Whitlatch, R.B., and Osman, R.W. (2002) Nonlinear partial differential equations and applications: Linking climate change and biological invasions: Ocean warming facilitates nonindigenous species invasions. Proceedings of the National Academy of Sciences 99, 15497-15500

Stam, W., Olsen, J., Zaleski, S., Murray, S., Brown, K., and Walters, L. (2006) A forensic and phylogenetic survey of Caulerpa species (Caulerpales, Chlorophyta) from the Florida coast local aquarium shops, and e-commerce; establishing a proactive baseline for early detection 1. Journal of Phycology 42, 1113-1124.

Stohlgren, T.J., Barnett, D., Flather, C., Kartesz, J., and Peterjohn, B. (2005) Plant species invasions along the latitudinal gradient in the United States. Ecology 86, 22982309.

Sun, Z., Hanyuda, T., Lim, P.-E., Tanaka. J., Gurgel, C.F.D. and Kawai, H. (2012) Taxonomic revision of the genus Lobophora (Dictyotales, Phaeophyceae) based on morphological evidence and analyses rbcl and cox3 gene sequences. Phycologia 51(5), 500-512.

Tamura, K., and Nei, M. (1993) "Estimation of the number of nucleotide substitutions in the control region of mitochondrial DNA in humans and chimpanzees". Molecular Biology and Evolution 10, 512-526.

Tang, L.D., Qiu, B.L., Cuthbertson, A.G.S., and Ren, S.X. (2015) Status of insecticide resistance and selection for imidacloprid resistance in the ladybird beetle Propylaea japonica (Thunberg). Pesticide Biochemistry and Physiology 123, 87.

Tavaré, S. (1986) "Some Probabilistic and Statistical Problems in the Analysis of DNA Sequences" (PDF). Lectures on Mathematics in the Life Sciences 17, 57-86.

Taylor, W. (1928) The Marine Algae of Florida with special reference to the Dry Tortugas. Carnegie Institution of Washington.

Taylor, S.L., Bishop, M.J., Kelaher, B.P., and Glasby, T.M. (2010) Impacts of detritus from the invasive alga Caulerpa taxifolia on a soft sediment community. Marine Ecology Progress Series 420, 73-81. 
Torrano-Silva, B.N., Amancio, C.E., and Oliveira, E.C. (2013) Seaweeds in ornamental aquaria in Brazil: anticipating introductions. Latin american journal of aquatic research 41, 344-350.

Tronholm, A., Sansón, M., Afonso-Carrillo, J., Verbruggen, H., and De Clerck, O. (2010) Niche partitioning and the coexistence of two cryptic Dictyota (Dictyotales, Phaeophyceae) species from the Canary Islands 1. Journal of Phycology 46, 1075-1087.

Valentine, J.P., and Johnson, C.R. (2004) Establishment of the introduced kelp Undaria pinnatifida following dieback of the native macroalga Phyllospora comosa in Tasmania, Australia. Marine and Freshwater Research 55, 223-230

Verbruggen, H. (2014) Morphological complexity, plasticity, and species diagnosability in the application of old species names in DNA - based taxonomies. Journal of Phycology 50, 26-31.

Verbruggen, H., De Clerck, O., Kooistra, W.H.C.F., and Coppejans, E. (2005) Molecular and morphometric data pinpoint species boundaries in Halimeda section Rhipsalis (Bryopsidales, Chlorophyta) 1. Journal of Phycology 41, 606-621.

Verbruggen, H., Leliaert, F., Maggs, C.A., Shimada, S., Schils, T., Provan, J., Booth, D., Murphy, S., De Clerck, O., Littler, D.S., Littler, M.M., and Coppejans, E. (2007) Species boundaries and phylogenetic relationships within the green algal genus Codium (Bryopsidales) based on plastid DNA sequences. Molecular Phylogenetics and Evolution 44, 240-254.

Verlaque, M. (2001) Checklist of the macroalgae of Thau Lagoon (Hérault, France), a hot spot of marine species introduction in Europe. Oceanologica Acta 24, 29-49.

Vermeij, M., Smith, T., Dailer, M., and Smith, C. (2009) Release from native herbivores facilitates the persistence of invasive marine algae: a biogeographical comparison of the relative contribution of nutrients and herbivory to invasion success. Biological Invasions 11, 1463-1474.

Vieira, C., Hondt, S., De Clerck, O., and Payri, C.E. (2014) Toward an inordinate fondness for stars, beetles and Lobophora? Species diversity of the genus Lobophora (Dictyotales, Phaeophyceae) in New Caledonia. Journal of Phycology 50, 1101-1119.

Vilà, M., Maron, J., and Marco, L. (2005) Evidence for the enemy release hypothesis in Hypericum perforatum. Oecologia 142, 474-479.

Vranken, S., Bosch, S., Peña, V., Leliaert, F., Mineur, F., and De Clerck, O. (2018) A risk assessment of aquarium trade introductions of seaweed in European waters. Biological Invasions 20, 1171-1187.

Westhoff, J.T., and Rabeni, C.F. (2013) Resource selection and space use of a native and an invasive crayfish: evidence for competitive exclusion? Freshwater Science 32, 13831397. 
Wynne, M.J. (2016) The proposal of Willeella brachyclados (Montagne) M.J.Wynne comb. nov. (Ulvophyceae). Notulae Algarum 18, 1-3.

Wynne, M.J. (2017) The reinstatement of Lychaete J.Agardh (Ulvophyceae, Cladophoraceae). Notulae Algarum 31, 1-4

Wynne, M.J,. Schneider, C.W. and Saunders, G.W. (2019) The reinstatement of Hooperia J.Agardh (Lomentariaceae, Rhodophyta) to accommodate Lomentaria divaricata (Durant) M.J.Wynne. Notulae Algarum 93, 1-2.

Wiedenmann, J., Baumstark, A., Pillen, T.L., Meinesz, A., and Vogel, W. (2001) DNA fingerprints of Caulerpa taxifolia provide evidence for the introduction of an aquarium strain into the Mediterranean Sea and its close relationship to an Australian population. International Journal on Life in Oceans and Coastal Waters 138, 229-234.

Wild, A. L. (2004). Taxonomy and distribution of the Argentine ant, Linepithema humile (Hymenoptera: Formicidae). Annals of the Entomological Society of America 97, 12041215.

Williams, S.L., and Smith, J.E. (2007) A global review of the distribution, taxonomy, and impacts of introduced seaweeds. In Annual Review of Ecology Evolution and Systematics 38, 327-359.

Wolf, M.A., Sfriso, A., Andreoli, C., and Moro, I. (2011) The presence of exotic Hypnea flexicaulis (Rhodophyta) in the Mediterranean Sea as indicated by morphology, $r b c \mathrm{~L}$ and cox1 analyses. Aquatic Botany 95, 55-58.

Wright, J. (2005) Differences between native and invasive Caulerpa taxifolia : a link between asexual fragmentation and abundance in invasive populations. International Journal on Life in Oceans and Coastal Waters 147, 559-569.

Yang, Z. (1994). Maximum Likelihood Phylogenetic Estimation from DNA Sequences with Variable Rates over Sites: Approximate Methods. Journal of molecular evolution 39, 306-314.

Yuan, A., Jeffries, N., and Zheng, G. (2013) "Maximum Likelihood." In Brenner's Encyclopedia of Genetics 328-29.

Zaleski, S., and Murray, S. (2006) Taxonomic diversity and geographic distributions of aquarium-traded species of Caulerpa (Chlorophyta: Caulerpaceae) in southern California, USA. Marine Ecology Progress Series 314, 97-108.

Zuccarello, G., and West, J. (2002) Phylogeography of the Bostrychia calliptera-B. pinnata complex ( Rhodomelaceae, Rhodophyta) and divergence rates based on nuclear, mitochondrial and plastid DNA markers. Phycologia 41, 49-60.

Zuccarello, G.C., Schidlo, N., McIvor, L., and Guiry, M.D. (2005) A molecular reexamination of speciation in the intertidal red algamastocarpus stellatus (gigartinales, rhodophyta) in Europe. European Journal of Phycology 40, 337-344 
Zuccarello, G.C., and West, J.A. (2003) Multiple cryptic species: Molecular diversity and reproductive isolation in the Bostrychia Radicans/B. Moritziana complex

(Rhodymeliaceae, Rhodophyta) with focous on North American isolates. Journal of Phycology 39, 948-959. 


\section{Supplimentry information}

Table S1. Algal samples collected from New Zealand marine aquaria. A total of 15 brown algae, 33 red algae and 34 green algae. Top blast hit and percent identity to the blast hit shown. Substrate coral species that the alga was collected from shown.

\begin{tabular}{|c|c|c|c|c|c|c|c|c|c|}
\hline Sample & $\begin{array}{l}\text { Voucher } \\
\text { ID Welt }\end{array}$ & $\begin{array}{l}\text { Genbank } \\
\text { accession }\end{array}$ & Name & Gene & $\begin{array}{l}\text { Sequence } \\
\text { length }\end{array}$ & $\begin{array}{l}\text { Top Blast hit, and Genbank } \\
\text { Accession Number }\end{array}$ & $\begin{array}{l}\% \\
\text { Identity } \\
\text { Blast }\end{array}$ & Substrate & $\begin{array}{l}\text { Collection } \\
\text { date }\end{array}$ \\
\hline A5 & TBA & - & Dictyopteris sp. & - & - & & & Live rock & 18-Jun-2017 \\
\hline A46 & TBA & TBA & Lobophora sp. & $\operatorname{cox} 3$ & 701 & Lobophora sp. 24, KU353342 & 99.4 & Caulastrea tumida & 3-Aug-2017 \\
\hline A6 & TBA & TBA & Turbinaria ornata & $\cos 3$ & 683 & Turbinaria ornata, KM501562 & 99.3 & dead Faviid & 5-Jun-2017 \\
\hline A47 & TBA & TBA & Lobophora sp. & $\operatorname{cox} 3$ & & & & Caulastrea tumida & 3-Aug-2017 \\
\hline A7 & TBA & TBA & Lobophora asiatica & $\operatorname{cox} 3$ & 696 & Lobophora sp., AB665369 & 99.8 & Zoanthus sp. & 8-Jun-2017 \\
\hline A32 & TBA & TBA & Lobophora asiatica & $\operatorname{cox} 3$ & 677 & Lobophora sp., AB665365 & 99.6 & Zoanthus sp. rock & 8-Jun-2017 \\
\hline A108 & TBA & TBA & Lobophora sp. & $\cos 3$ & 700 & Lobophora sp. 6, KU353257 & 99.8 & Pavona sp. skeleton & 8-Jun-2017 \\
\hline A57 & TBA & TBA & Lobophora sp. & $\operatorname{cox} 3$ & 702 & Lobophora sp. 57, KU353343 & 97.4 & $\begin{array}{l}\text { Maricultured } \\
\text { Seriatopora hystrix }\end{array}$ & 12-Jun-2017 \\
\hline A58 & TBA & TBA & $\begin{array}{l}\text { Lobophora } \\
\text { abscondita }\end{array}$ & $\operatorname{cox} 3$ & 687 & $\begin{array}{l}\text { Lobophora abscondita, } \\
\text { KU353163 }\end{array}$ & 99.4 & Galaxea sp. & 12-Jun-2017 \\
\hline A59 & TBA & TBA & Dictyopteris sp. & & & & & Hammer coral & 12-Jun-2017 \\
\hline A60 & TBA & TBA & Lobophora sp. & $\cos 3$ & 705 & Lobophora petila, KU353324 & 94.3 & Favia speciosa & 5-Dec-2017 \\
\hline A61 & TBA & TBA & Lobophora sp. & $\operatorname{cox} 3$ & 675 & Lobophora sp. 10, KU353273 & 99.5 & Caulastrea furcata & 5-Dec-2017 \\
\hline A62 & TBA & TBA & Dictyota friabilis & $\operatorname{cox} 3$ & 692 & Dictyota friabilis, GU290244 & 93.6 & Favites sp. & 5-Dec-2017 \\
\hline A109 & TBA & TBA & Dictyopteris sp. & $\operatorname{cox} 3$ & 636 & $\begin{array}{l}\text { Dictyopteris polypodioides, } \\
\text { EU681445 }\end{array}$ & 80.7 & Zoanthus sp. & 8-Aug-2018 \\
\hline A110 & TBA & TBA & Dictyota sp. & $\cos 3$ & 645 & Dictyota friabilis, GU290244 & 90.3 & Zoanthus sp. & 8-Aug-2018 \\
\hline A1 & TBA & TBA & Chondrophycus sp. & $\operatorname{cox} 1$ & 614 & Chondrophycus sp., KX258817 & 96.3 & $\begin{array}{l}\text { Maricultured } \\
\text { Acropora sp }\end{array}$ & 4-Aug-2017 \\
\hline $\mathrm{A} 2$ & TBA & TBA & Lomentaria sp. & $\operatorname{cox} 1$ & 684 & $\begin{array}{l}\text { Lomentaria divaricata, } \\
\text { KU941949 }\end{array}$ & 86.6 & $\begin{array}{l}\text { Retailers tank on } \\
\text { sand bed }\end{array}$ & 10-Aug-2017 \\
\hline
\end{tabular}




\begin{tabular}{|c|c|c|c|c|c|c|c|c|c|}
\hline A3 & TBA & TBA & Meredithia sp. & $\operatorname{cox} 1$ & 681 & Meredithia sp., KC157609 & 99.5 & $\begin{array}{l}\text { Retailers tank } \\
\text { attached to glass }\end{array}$ & 10-Aug-2017 \\
\hline A107 & TBA & TBA & Chondrophycus sp. & $\operatorname{cox} 1$ & 634 & Chondrophycus sp., HQ423056 & 92.3 & $\begin{array}{l}\text { Maricultured } \\
\text { Acropora } \mathrm{sp} .\end{array}$ & 14-Aug-2017 \\
\hline A106 & TBA & TBA & Ceratodictyon sp. & $\operatorname{cox} 1$ & 680 & Gelidiopsis sp., HQ422790 & 99.8 & starburst polyp rock & 14-Aug-2017 \\
\hline A4 & TBA & TBA & Halopeltis sp. & $\operatorname{cox} 1$ & 684 & Halopeltis willisii, HM915686 & 90.8 & Acropora sp. & 15-Aug-2017 \\
\hline A8 & TBA & TBA & Chondrophycus sp. & $\operatorname{cox} 1$ & 668 & Chondrophycus sp., KX258815 & 91.7 & Acropora sp. & 15-Aug-2017 \\
\hline A9 & TBA & TBA & Chamaebotrys sp2 & $r b c \mathrm{~L}$ & 322 & Chamaebotrys sp., KU726727 & 91.1 & Fragment tile & 15-Aug-2017 \\
\hline A105 & TBA & TBA & Ceratodictyon $\mathrm{sp}$. & $\operatorname{cox} 1$ & 681 & Gelidiopsis sp., HQ422790 & 99.8 & Acropora sp & 15-Aug-2017 \\
\hline A23 & TBA & TBA & Chamaebotrys sp1 & $r b c \mathrm{~L}$ & 317 & $\begin{array}{l}\text { Chrysymenia brownii, } \\
\text { KU726719 }\end{array}$ & 91.3 & Zoanthus sp. rock & 20-Aug-2017 \\
\hline A104 & TBA & TBA & Peyssonnelia sp. & $\operatorname{cox} 1$ & 682 & Peyssonnelia sp., JX969686 & 91.4 & $\begin{array}{l}\text { Personal reef on } \\
\text { rocks }\end{array}$ & \\
\hline A33 & TBA & TBA & Amphiroa sp. & $\operatorname{cox} 1$ & 682 & Amphiroa anceps, LC071723 & 91.1 & Zoanthus sp. rock & 20-Aug-2017 \\
\hline A70 & TBA & TBA & Peyssonnelia sp. & $\operatorname{cox} 1$ & 589 & Peyssonnelia sp., JX969736 & 92.7 & Zoanthus sp. rock & 5-Jan-2018 \\
\hline A52 & TBA & TBA & Pterocladiella $\mathrm{sp}$. & $\operatorname{cox} 1$ & 685 & $\begin{array}{l}\text { Pterocladiella phangiae, } \\
\text { KC209092 }\end{array}$ & 90.6 & Caulastrea sp. & 13-Dec-2017 \\
\hline A53 & TBA & TBA & Peyssonnelia sp. & $\operatorname{cox} 1$ & 685 & Peyssonnelia rubra, HQ422737 & 92.4 & Caulastrea $\mathrm{sp}$. & 13-Dec-2017 \\
\hline A98 & TBA & TBA & Pterocladiella $\mathrm{sp}$. & $\operatorname{cox} 1$ & 591 & $\begin{array}{l}\text { Pterocladiella beachiae, } \\
\text { KT208059 }\end{array}$ & 91.7 & Galaxea sp. & 19-Sept-2017 \\
\hline A97 & TBA & TBA & Hypnea wynnei & $\operatorname{cox} 1$ & 540 & Hypnea sp., KX426549 & 99.8 & $\begin{array}{l}\text { Maricultured } \\
\text { Seriatopora hystrix }\end{array}$ & 19-Sept-2017 \\
\hline A96 & TBA & TBA & Laurencia sp. & $\operatorname{cox} 1$ & 583 & Laurencia saitoi, KM254876 & 94.5 & Zoanthus sp. rock & 9-Nov-2-17 \\
\hline A95 & TBA & TBA & Hypnea wynnei & $\operatorname{cox} 1$ & 598 & Hypnea sp., KX426549 & 99.8 & $\begin{array}{l}\text { Maricultured } \\
\text { Acropora sp. }\end{array}$ & 13-Dec-2-17 \\
\hline A64 & TBA & TBA & Chamaebotrys sp2 & $r b c \mathrm{~L}$ & 325 & Chamaebotrys sp., KU726727 & 91.6 & Caulastrea sp. & 13-Dec-2-17 \\
\hline A67 & TBA & TBA & Leptofauchea sp. & $\operatorname{cox} 1$ & 627 & $\begin{array}{l}\text { Leptofauchea leptophylla, } \\
\text { KF547030 }\end{array}$ & 91.4 & Hobbyist in Auckland & 9-Jan-2018 \\
\hline A68 & TBA & TBA & $\begin{array}{l}\text { Pterocladiella } \\
\text { caerulescens }\end{array}$ & $\operatorname{cox} 1$ & 607 & $\begin{array}{l}\text { Pterocladiella caerulescens, } \\
\text { KX557255 }\end{array}$ & 99.6 & Hobbyist in Auckland & 9-Jan-2018 \\
\hline A69 & TBA & TBA & Hypnea wynnei & $\operatorname{cox} 1$ & 596 & Hypnea sp., KX426549 & 100 & Hobbyist in Auckland & 9-Jan-2018 \\
\hline A94 & TBA & TBA & Hypnea sp. & $\operatorname{cox} 1$ & 597 & Hypnea brasiliensis, KU905079 & 98.9 & Zoanthus sp. rock & 1-Mar-2018 \\
\hline
\end{tabular}




\begin{tabular}{|c|c|c|c|c|c|c|c|c|c|}
\hline A93 & TBA & TBA & $\begin{array}{l}\text { Pterocladiella } \\
\text { caerulescens }\end{array}$ & $\operatorname{cox} 1$ & 594 & $\begin{array}{l}\text { Pterocladiella caerulescens, } \\
\text { KX557255 }\end{array}$ & 99.6 & Euphyllia ancora & 1-Apr-2018 \\
\hline A86 & TBA & TBA & Peyssonnelia sp. & $\operatorname{cox} 1$ & 620 & Peyssonnelia sp., KM254773 & 91.6 & Ricordea florida rock & 11-Apr-2018 \\
\hline A84 & TBA & TBA & Ramicrusta sp. & $\operatorname{cox} 1$ & 593 & Ramicrusta appressa, JX969695 & 93.4 & $\begin{array}{l}\text { Microzoanthus } \\
\text { sp.rock }\end{array}$ & 4-Aug-2017 \\
\hline A55 & TBA & TBA & Hypnea wynnei & $\operatorname{cox} 1$ & 621 & Hypnea sp., KX426549 & 99.8 & $\begin{array}{l}\text { Retailers tank on egg } \\
\text { crate }\end{array}$ & \\
\hline A56 & TBA & TBA & Hypnea spinella & $\operatorname{cox} 1$ & 626 & Hypnea spinella, KU905111 & 97.2 & $\begin{array}{l}\text { Retailers tank on egg } \\
\text { crate }\end{array}$ & \\
\hline A99 & TBA & TBA & $\begin{array}{l}\text { Ceratodictyon } \\
\text { repens }\end{array}$ & $\operatorname{cox} 1$ & 627 & $\begin{array}{l}\text { Ceratodictyon repens, } \\
\text { KY656528 }\end{array}$ & 99.4 & Anemone rock & 5-Jun-2018 \\
\hline A92 & TBA & TBA & Ramicrusta sp. & $\operatorname{cox} 1$ & 639 & Ramicrusta appressa, JX969695 & 93.8 & $\begin{array}{l}\text { Maricultured } \\
\text { Hydnophora sp. }\end{array}$ & 5-Jun-2018 \\
\hline A101 & TBA & TBA & Hypnea sp. & $\operatorname{cox} 1$ & 568 & Gigartinales sp., HQ423064 & 100 & \multicolumn{2}{|c|}{ Personal reef on T. noae shell } \\
\hline A102 & TBA & TBA & Laurencia $\mathrm{sp}$. & $\operatorname{cox} 1$ & 587 & Laurencia sp., GU223893 & 94 & Zoanthus sp. rock & 1-Oct-2018 \\
\hline A111 & TBA & TBA & $\begin{array}{l}\text { Caulerpa } \\
\text { nummularia }\end{array}$ & tufA & 918 & $\begin{array}{l}\text { Caulerpa nummularia, } \\
\text { JN851138 }\end{array}$ & 99.9 & $\begin{array}{l}\text { Personal reef on } \\
\text { rocks }\end{array}$ & \\
\hline A19 & TBA & TBA & Lychaete dotyana & LSU & 578 & Lychaete dotyana, LT904846 & 99.5 & Zoanthus sp. rock & \\
\hline A20 & TBA & TBA & Udotea $\mathrm{sp}$. & $r b c \mathrm{~L}$ & 117 & $\begin{array}{l}\text { Riphidosiphon sp. G.008, } \\
\text { AB700348 }\end{array}$ & 95.7 & Zoanthus sp. rock & \\
\hline A27 & TBA & TBA & Valonia ventricosa & LSU & 575 & $\begin{array}{l}\text { Ventricaria ventricosa, } \\
\text { AM503545 }\end{array}$ & 100 & $\begin{array}{l}\text { Personal reef on } \\
\text { rocks }\end{array}$ & \\
\hline A36 & TBA & TBA & Cladophoropsis sp. & LSU & 587 & $\begin{array}{l}\text { Cladophoropsis membranacea, } \\
\text { AM503489 }\end{array}$ & 99.8 & Zoanthus sp. rock & \\
\hline A45 & TBA & TBA & Caulerpa serrulata & tufA & 819 & Caulerpa serrulata, KJ957119 & 100 & \multicolumn{2}{|c|}{$\begin{array}{l}\text { Donated by reef hobbyist Wellington in } \\
\text { sump }\end{array}$} \\
\hline A35 & TBA & TBA & Derbesia $\mathrm{sp}$. & tufA & 886 & $\begin{array}{l}\text { Derbesia } \text { sp. TS1731, } \\
\text { KU361859 }\end{array}$ & 99.4 & $\begin{array}{l}\text { Personal reef on } \\
\text { rocks }\end{array}$ & 16-Jul-2017 \\
\hline A43 & TBA & TBA & Cladophoropsis sp. & LSU & 578 & $\begin{array}{l}\text { Cladophoropsis membranacea, } \\
\text { AM503489 }\end{array}$ & 99.8 & Zoanthus sp. rock & \\
\hline A39 & TBA & TBA & Lychaete dotyana & LSU & 580 & Lychaete dotyana, LT904846 & 99.7 & Zoanthus sp. rock & \\
\hline A26 & TBA & TBA & $\begin{array}{l}\text { Caulerpa } \\
\text { lentillifera }\end{array}$ & tufA & 853 & $\begin{array}{l}\text { Caulerpa lentillifera, } \\
\text { NC } 039377\end{array}$ & 100 & Zoanthus sp. rock & 7-Jul-2017 \\
\hline A25 & TBA & TBA & Caulerpa & tufA & 930 & Caulerpa cylindracea, & 100 & Zoanthus sp. rock & 7-Jul-2017 \\
\hline
\end{tabular}




\begin{tabular}{|c|c|c|c|c|c|c|c|c|c|}
\hline & & & cylindracea & & & FM956048 & & & \\
\hline A41 & TBA & TBA & Caulerpa racemosa & tufA & 894 & Caulerpa racemosa, DQ652466 & 100 & Zoanthus sp. rock & 7-Jul-2017 \\
\hline A34 & TBA & TBA & Lychaete sp. & LSU & 585 & $\begin{array}{l}\text { Cladophora feredayi, } \\
\text { FM205030 }\end{array}$ & 93.7 & Zoanthus sp. rock & 12-Jul-2017 \\
\hline A114 & TBA & TBA & Lychaete sp. & LSU & 585 & $\begin{array}{l}\text { Cladophora feredayi, } \\
\text { FM205030 }\end{array}$ & 93.8 & $\begin{array}{l}\text { Personal reef on } \\
\text { fragment racks }\end{array}$ & 16-Jul-2017 \\
\hline A38 & TBA & TBA & Willeella sp. & LSU & 587 & $\begin{array}{l}\text { Cladophora montagneana, } \\
\text { LT607098 }\end{array}$ & 97.2 & $\begin{array}{l}\text { Personal reef on } \\
\text { fragment racks }\end{array}$ & 16-Jul-2017 \\
\hline A42 & TBA & TBA & Ulva ohnoi & tufA & 554 & Ulva ohnoi, MF614793 & 100 & $\begin{array}{l}\text { Retailers tank free } \\
\text { living }\end{array}$ & 16-Jul-2017 \\
\hline A40 & TBA & TBA & $\begin{array}{l}\text { Caulerpa racemosa } \\
\text { var. macrophysa }\end{array}$ & tufA & 895 & Caulerpa racemosa, KJ957088 & 100 & Zoanthus sp. rock & 16-Jul-2017 \\
\hline A54 & TBA & TBA & Valonia ventricosa & LSU & 584 & $\begin{array}{l}\text { Ventricaria ventricosa, } \\
\text { AM503545 }\end{array}$ & 100 & Coral fragment & 20-Aug-2017 \\
\hline A76 & TBA & TBA & Udotea sp. & $r b c \mathrm{~L}$ & 128 & Udotea sp., MH591113 & 95.3 & $\begin{array}{l}\text { Reailers tank on } \\
\text { rocks }\end{array}$ & 20-Aug-2017 \\
\hline A75 & TBA & TBA & Valonia fastigiata & LSU & 564 & Valonia fastigiata, AM503532 & 98.38 & $\begin{array}{l}\text { Retailers tank on } \\
\text { rocks }\end{array}$ & 26-Aug-2017 \\
\hline A100 & TBA & TBA & Bryopsis sp. & tufA & 911 & Bryopsis sp. 2, LK022439 & 87.22 & Personal reef on glass & 10-Oct-2017 \\
\hline A82 & TBA & TBA & Lurbica sp. & LSU & 436 & $\begin{array}{l}\text { Chaetomorpha } \mathrm{cf} . \\
\text { restricta/linoides, LT607144 }\end{array}$ & 97.6 & $\begin{array}{l}\text { Retailers tank on egg } \\
\text { crate }\end{array}$ & 18-Dec-2017 \\
\hline A78 & TBA & & $\begin{array}{l}\text { Caulerpa } \\
\text { sertularioides }\end{array}$ & & & & & Hobbyist in Auckland & 9-Jan-2018 \\
\hline A80 & TBA & TBA & $\begin{array}{l}\text { Chaetomorpha } \\
\text { vieillardii }\end{array}$ & LSU & 622 & $\begin{array}{l}\text { Chaetomorpha spiralis, } \\
\text { LT607221 }\end{array}$ & 99.6 & Hobbyist in Auckland & 9-Jan-2018 \\
\hline A73 & TBA & TBA & $\begin{array}{l}\text { Valonia } \\
\text { macrophysa }\end{array}$ & LSU & 582 & $\begin{array}{l}\text { Valonia macrophysa, } \\
\text { AM503536 }\end{array}$ & 100 & Hobbyist in Auckland & 9-Jan-2018 \\
\hline A79 & TBA & TBA & Caulerpa racemosa & tufA & 768 & $\begin{array}{l}\text { Caulerpa racemosa isolate } \\
\text { FL108, DQ652426 }\end{array}$ & 100 & Hobbyist in Auckland & 9-Jan-2018 \\
\hline A88 & TBA & TBA & Halimeda sp. & $r b c \mathrm{~L}$ & 126 & Halimeda aff. tuna, KY570457 & 96 & Hobbyist in Auckland & 9-Jan-2018 \\
\hline A91 & TBA & TBA & $\begin{array}{l}\text { Caulerpa } \\
\text { chemnitzia }\end{array}$ & tufA & 878 & Caulerpa chemnitzia, KJ957093 & 99.9 & Zoanthus sp. rock & 11-Apr-2018 \\
\hline A113 & TBA & TBA & Willeella sp. & LSU & 588 & $\begin{array}{l}\text { Cladophora montagneana, } \\
\text { LT607098 }\end{array}$ & 97.2 & Zoanthus sp. rock & 11-Apr-2018 \\
\hline
\end{tabular}




\begin{tabular}{|c|c|c|c|c|c|c|c|c|c|}
\hline A112 & TBA & TBA & $\begin{array}{l}\text { Chaetomorpha } \\
\text { vieillardii }\end{array}$ & LSU & 632 & $\begin{array}{l}\text { Chaetomorpha spiralis, } \\
\text { LT607221 }\end{array}$ & 100 & Blastomussa vivida & 22-Apr-2018 \\
\hline A74 & TBA & TBA & $\begin{array}{l}\text { Valonia } \\
\text { macrophysa }\end{array}$ & LSU & 580 & $\begin{array}{l}\text { Valonia macrophysa, } \\
\text { AM503536 }\end{array}$ & 99.8 & Hobbyist in Hamilton & \\
\hline A66 & TBA & TBA & Udotea $\mathrm{sp}$. & $r b c \mathrm{~L}$ & 126 & Udotea sp., MH591113 & 96 & Zoanthus sp. rock & 22-Jun-2018 \\
\hline A116 & TBA & TBA & $\begin{array}{l}\text { Valonia } \\
\text { macrophysa }\end{array}$ & LSU & 583 & $\begin{array}{l}\text { Valonia macrophysa, } \\
\text { AM503536 }\end{array}$ & 99.8 & Mushroom coral rock & 30-Jun-2018 \\
\hline A115 & TBA & TBA & Willeella sp. & LSU & 600 & $\begin{array}{l}\text { Cladophora montagneana, } \\
\text { LT607098 }\end{array}$ & 97.2 & Aragonite substrate & \\
\hline
\end{tabular}


Table S2. Table of the genes and primer pairs used for the different groups of macroalgae. Amplicon size and annealing temperatures are shown.

\begin{tabular}{|c|c|c|c|c|c|c|}
\hline Algae type & preliminary ID & Gene & $\begin{array}{c}\text { Primers used } \\
\end{array}$ & $\begin{array}{c}\text { Approx. } \\
\text { amplicon size }\end{array}$ & $\begin{array}{c}\text { Annealing } \\
\text { temperature }\end{array}$ & References \\
\hline Phaeophyceae & $\begin{array}{l}\text { Dictyota sp., } \\
\text { Lobophora spp. }\end{array}$ & $\cos 3$ & $\begin{array}{l}\text { cox3-44F } \\
\text { CATCGACAAAATGCCAATACCA } \\
\text { cox3-739R } \\
\text { CAACGNCAYCCWTTTCATTT }\end{array}$ & $717 \mathrm{bp}$ & $45^{\circ} \mathrm{C}$ & Vieira et. al. 2014 \\
\hline Rhodophyta & $\begin{array}{l}\text { Amphiroa sp., } \\
\text { Gelidiopsis spp., } \\
\text { Hypnea spp., } \\
\text { Laurencia spp., } \\
\text { Peyssonnelia spp. } \\
\text { Pterocladiella spp. }\end{array}$ & $\operatorname{cox} 1$ & $\begin{array}{l}\text { Gaz-F1 } \\
\text { TCAACAAATCATAAAGATATTGG } \\
\text { GAZ-R1 } \\
\text { ACTTCTGGATGTCCAAAAAAYCA }\end{array}$ & $710 \mathrm{bp}$ & $45^{\circ} \mathrm{C}$ & Saunders 2005 \\
\hline Rhodophyta & Botryocladia spp. & $r b c \mathrm{~L}$ & $\begin{array}{l}r b c \text { L-765F } \\
\text { TGAAAGAGCTGAATTYGCTAA, } \\
r b c \text { L-1150R } \\
\text { GCATTTTGTCCGCAGTGAATACC }\end{array}$ & $408 \mathrm{bp}$ & $50^{\circ} \mathrm{C}$ & $\begin{array}{l}\text { Freshwater et. al. } \\
1994\end{array}$ \\
\hline Ulvophyceae & $\begin{array}{l}\text { Bryopsis plumosa, } \\
\text { Caulerpa } \text { spp., } \\
\text { Derbesia } \text { sp., } \\
\text { Ulva } \text { sp. }\end{array}$ & tufA & $\begin{array}{l}\text { CAUL-tufAF } \\
\text { TGAAACAGAAMAWCGTCATTATGC } \\
\text { CAUL-tufAR } \\
\text { CCTTCNCGAATMGCRAAWCGC }\end{array}$ & $852 \mathrm{bp}$ & $50^{\circ} \mathrm{C}$ & Fama et. al. 2002 \\
\hline Ulvophyceae & $\begin{array}{l}\text { Halimeda sp., } \\
\text { Udotea sp. }\end{array}$ & $r b c \mathrm{~L}$ & $\begin{array}{l}r b c \text { L-712F } \\
\text { CATTAYTTAAATGCWACWGC } \\
\text { rbcL-904R } \\
\text { CAATAACMGCRTGCATAGC }\end{array}$ & $190 \mathrm{bp}$ & $50^{\circ} \mathrm{C}$ & $\begin{array}{l}\text { Lagourgue et. al. } \\
\text { (2018) }\end{array}$ \\
\hline Cladophorales & $\begin{array}{l}\text { Chaetomorpha spp, } \\
\text { Cladophora spp, } \\
\text { Cladophoropsis spp. } \\
\text { Valonia spp. }\end{array}$ & $\begin{array}{l}\text { LSU } \\
28 \mathrm{~S}\end{array}$ & $\begin{array}{l}C^{\prime 1} \\
\text { ACCCGCTGAATTTAAGCATAT } \\
\text { D2 } \\
\text { TCCGTGTTTCAAGACGG }\end{array}$ & $590 \mathrm{bp}$ & $55^{\circ} \mathrm{C}$ & $\begin{array}{l}\text { Hassouna et. al. } \\
\text { (1984) }\end{array}$ \\
\hline
\end{tabular}


Table S3. Table of best-fit models selected by IQtree Modelfinder for codon partitions. 1, 2, 3 are the codon positions. Selection was based on Bayesian Information Criterion (BIC). Log-likelihoods for the maximum likelihood trees shown.

\begin{tabular}{|c|c|c|c|c|}
\hline Dataset & $\begin{array}{c}\text { Alignment } \\
\text { length }\end{array}$ & $\begin{array}{l}\text { Best fit model for } \\
\text { partitions }\end{array}$ & $\begin{array}{l}\text { Informative } \\
\text { sites per } \\
\text { codon }\end{array}$ & $\begin{array}{c}\text {-log likelihood of } \mathrm{ML} \\
\text { tree }\end{array}$ \\
\hline $\begin{array}{c}\text { Hypnea spp. } \\
\text { alignment - Cox } 1\end{array}$ & $546 \mathrm{bp}$ & $\begin{array}{l}\text { 1. } \mathrm{TIM} 3 \mathrm{e}+\mathrm{I}+\mathrm{G} 4 \\
\text { 2. } \mathrm{HKY}+\mathrm{F}+\mathrm{I}+\mathrm{G} 4 \\
\text { 3. } \mathrm{TN}+\mathrm{F}+\mathrm{G} 4\end{array}$ & $\begin{array}{l}1.31 \\
2.2 \\
3.157\end{array}$ & 3979.3985 \\
\hline $\begin{array}{l}\text { Chondrophycus spp. } \\
\text { alignment Cox } 1\end{array}$ & $660 \mathrm{bp}$ & $\begin{array}{l}\text { 1. } \mathrm{TN}+\mathrm{F}+\mathrm{I}+\mathrm{G} 4 \\
\text { 2. } \mathrm{F} 81+\mathrm{F}+\mathrm{I}+\mathrm{G} 4 \\
\text { 3. } \mathrm{TN}+\mathrm{F}+\mathrm{G} 4\end{array}$ & $\begin{array}{l}1.17 \\
2.1 \\
3.116\end{array}$ & 2937.3471 \\
\hline $\begin{array}{c}\text { Laurencia spp. } \\
\text { alignment - Cox } 1\end{array}$ & $660 \mathrm{bp}$ & $\begin{array}{l}\text { 1. } \mathrm{HKY}+\mathrm{F}+\mathrm{I}+\mathrm{G} 4 \\
\text { 2. } \mathrm{HKY}+\mathrm{F}+\mathrm{I}+\mathrm{G} 4 \\
\text { 3. } \mathrm{TN}+\mathrm{F}+\mathrm{G} 4\end{array}$ & $\begin{array}{l}1.15 \\
2.1 \\
3.125\end{array}$ & 2957.4923 \\
\hline $\begin{array}{l}\text { Pterocladiella spp. } \\
\text { alignment - Cox } 1\end{array}$ & $543 \mathrm{bp}$ & $\begin{array}{l}\text { 1. } \mathrm{TN}+\mathrm{F}+\mathrm{G} 4 \\
\text { 2. } \mathrm{F} 81+\mathrm{F}+\mathrm{I}+\mathrm{G} 4 \\
\text { 3. } \mathrm{TN}+\mathrm{F}+\mathrm{G} 4\end{array}$ & $\begin{array}{l}1.23 \\
2.1 \\
3.140\end{array}$ & 2951.4536 \\
\hline $\begin{array}{l}\text { Peyssonnelia spp. } \\
\text { alignment - Cox } 1\end{array}$ & $663 \mathrm{bp}$ & $\begin{array}{l}\text { 1. } \mathrm{TNe}+\mathrm{I}+\mathrm{G} 4 \\
\text { 2. } \mathrm{HKY}+\mathrm{F}+\mathrm{I}+\mathrm{G} 4 \\
\text { 3. } \mathrm{TIM} 2+\mathrm{F}+\mathrm{I}+\mathrm{G} 4\end{array}$ & $\begin{array}{l}1.30 \\
2.1 \\
\text { 3. } 178\end{array}$ & 5084.6474 \\
\hline $\begin{array}{l}\text { Ramicrusta spp. } \\
\text { alignment - Cox } 1\end{array}$ & $663 \mathrm{bp}$ & $\begin{array}{l}\text { 1. } \mathrm{TNe}+\mathrm{I}+\mathrm{G} 4 \\
\text { 2. } \mathrm{F} 81+\mathrm{F}+\mathrm{I}+\mathrm{G} 4 \\
\text { 3. } \mathrm{TIM} 2+\mathrm{F}+\mathrm{G} 4\end{array}$ & $\begin{array}{l}1.27 \\
2.3 \\
3.123\end{array}$ & 2619.0675 \\
\hline $\begin{array}{l}\text { Meredithia spp. } \\
\text { alignment - Cox } 1\end{array}$ & $663 \mathrm{bp}$ & $\begin{array}{l}\text { 1. } \mathrm{K} 2 \mathrm{P}+\mathrm{I}+\mathrm{G} 4 \\
\text { 2. } \mathrm{F} 81+\mathrm{F}+\mathrm{I}+\mathrm{G} 4 \\
\text { 3. } \mathrm{HKY}+\mathrm{F}+\mathrm{G} 4\end{array}$ & $\begin{array}{l}1.19 \\
2.2 \\
3.104\end{array}$ & 2548.8707 \\
\hline $\begin{array}{l}\text { Leptofauchea spp. } \\
\text { alignment - Cox } 1\end{array}$ & $663 \mathrm{bp}$ & $\begin{array}{l}\text { 1. } \mathrm{TN}+\mathrm{F}+\mathrm{I}+\mathrm{G} 4 \\
\text { 2. } \mathrm{HK}+\mathrm{F}+\mathrm{I}+\mathrm{G} 4 \\
\text { 3. } \mathrm{TN}+\mathrm{F}+\mathrm{G} 4\end{array}$ & $\begin{array}{l}1.28 \\
2.1 \\
3.153\end{array}$ & 3367.7261 \\
\hline $\begin{array}{l}\text { Halopeltis spp. } \\
\text { alignment - Cox } 1\end{array}$ & $663 \mathrm{bp}$ & $\begin{array}{l}\text { 1. } \mathrm{TIM}+\mathrm{F}+\mathrm{I}+\mathrm{G} 4 \\
\text { 2. } \mathrm{F} 81+\mathrm{F}+\mathrm{I}+\mathrm{G} 4 \\
\text { 3. } \mathrm{TIM}+\mathrm{F}+\mathrm{G} 4\end{array}$ & $\begin{array}{l}1.38 \\
2.2 \\
3.170\end{array}$ & 3834.0478 \\
\hline $\begin{array}{l}\text { Gelidiopsis spp. and } \\
\text { Ceratodictyon spp. } \\
\text { alignment - Cox } 1\end{array}$ & $663 \mathrm{bp}$ & $\begin{array}{l}\text { 1. } \mathrm{TIM} 3 \mathrm{e}+\mathrm{G} 4 \\
\text { 2. } \mathrm{F} 81+\mathrm{F}+\mathrm{I}+\mathrm{G} 4 \\
\text { 3. } \mathrm{TN}+\mathrm{F}+\mathrm{G} 4\end{array}$ & $\begin{array}{l}1.5 \\
2.1 \\
3.59\end{array}$ & 1676.4889 \\
\hline $\begin{array}{l}\text { Lomentaria spp. } \\
\text { alignment - Cox } 1\end{array}$ & $663 b p$ & $\begin{array}{l}\text { 1. } \mathrm{TN}+\mathrm{F}+\mathrm{I}+\mathrm{G} 4 \\
\text { 2. } \mathrm{F} 81+\mathrm{F}+\mathrm{I}+\mathrm{G} 4 \\
\text { 3. } \mathrm{TPM} 2 \mathrm{u}+\mathrm{F}+\mathrm{G} 4\end{array}$ & $\begin{array}{l}1.29 \\
2.1 \\
3.130\end{array}$ & 2659.4569 \\
\hline $\begin{array}{l}\text { Chamaebotrys spp. } \\
\text { alignment }-r b c \mathrm{~L}\end{array}$ & 329 bp & $\begin{array}{l}\text { 1. } \mathrm{K} 2 \mathrm{P}+\mathrm{I}+\mathrm{G} 4 \\
\text { 2. } \mathrm{HKY}+\mathrm{F}+\mathrm{G} 4 \\
\text { 3. } \mathrm{TNe}+\mathrm{G} 4\end{array}$ & $\begin{array}{l}1.2 \\
2.72 \\
3.13\end{array}$ & 2140.1985 \\
\hline $\begin{array}{c}\text { Amphiroa spp. } \\
\text { alignment - Cox } 1\end{array}$ & $648 \mathrm{bp}$ & $\begin{array}{l}\text { 1. } \mathrm{TN}+\mathrm{F}+\mathrm{I}+\mathrm{G} 4 \\
\text { 2. } \mathrm{F} 81+\mathrm{F}+\mathrm{I}+\mathrm{G} 4 \\
\text { 3. } \mathrm{TN}+\mathrm{F}+\mathrm{G} 4\end{array}$ & $\begin{array}{l}1.45 \\
2.3 \\
3.173\end{array}$ & 4824.3257 \\
\hline $\begin{array}{l}\text { Ulva ohnoi alignment } \\
\text { - tufA }\end{array}$ & 784 bp & $\begin{array}{l}\text { 1. } \mathrm{TPM} 3 \mathrm{u}+\mathrm{F}+\mathrm{I}+\mathrm{G} 4 \\
\text { 2. } \mathrm{K} 3 \mathrm{Pu}+\mathrm{F}+\mathrm{I}+\mathrm{G} 4 \\
\text { 3. } \mathrm{TPM} 3+\mathrm{F}+\mathrm{I}+\mathrm{G} 4\end{array}$ & $\begin{array}{l}1.28 \\
2.64 \\
3.37\end{array}$ & 3637.052 \\
\hline $\begin{array}{l}\text { Chaetomorpha spp. } \\
\text { alignment - LSU }\end{array}$ & $584 \mathrm{bp}$ & 1. $\mathrm{TNe}+\mathrm{G} 4$ & 1. 104 & 2208.2511 \\
\hline Cladophora spp. LSU & $623 b p$ & 1. TIM3e+I+G4 & 1.147 & 2814.9532 \\
\hline
\end{tabular}




\begin{tabular}{|c|c|c|c|c|}
\hline $\begin{array}{l}\text { Cladophoropsis spp. } \\
\text { alignment - LSU }\end{array}$ & $567 \mathrm{bp}$ & 1. K2P & 1.11 & 1090.434 \\
\hline $\begin{array}{l}\text { Valonia spp. } \\
\text { alignment - LSU }\end{array}$ & $583 \mathrm{bp}$ & 1. $\mathrm{TN}+\mathrm{F}+\mathrm{G} 4$ & 1.32 & 1282.2955 \\
\hline $\begin{array}{l}\text { Bryopsis spp. } \\
\text { alignment - tufA }\end{array}$ & $876 \mathrm{bp}$ & $\begin{array}{l}\text { 1. } \mathrm{TIM} 2+\mathrm{F}+\mathrm{I}+\mathrm{G} 4 \\
\text { 2. } \mathrm{HKY}+\mathrm{F}+\mathrm{I}+\mathrm{G} 4 \\
\text { 3. } \mathrm{GTR}+\mathrm{F}+\mathrm{G} 4\end{array}$ & $\begin{array}{l}1.24 \\
2.9 \\
3.155\end{array}$ & 3780.6972 \\
\hline $\begin{array}{l}\text { Derbesia spp. } \\
\text { alignment -tufA }\end{array}$ & $861 \mathrm{bp}$ & $\begin{array}{l}\text { 1. } \mathrm{TIM} 3+\mathrm{F}+\mathrm{G} 4 \\
\text { 2. } \mathrm{TPM} 3 \mathrm{u}+\mathrm{F}+\mathrm{I}+\mathrm{G} 4 \\
\text { 3. } \mathrm{K} 3 \mathrm{Pu}+\mathrm{F}+\mathrm{G} 4\end{array}$ & $\begin{array}{l}1.34 \\
2.13 \\
3.172\end{array}$ & 3853.0682 \\
\hline $\begin{array}{l}\text { Halimeda spp. } \\
\text { alignment - } r b c \mathrm{~L}\end{array}$ & $135 \mathrm{bp}$ & $\begin{array}{l}\text { 1. } \mathrm{TIMe}+\mathrm{G} 4 \\
\text { 2. } \mathrm{JC}+\mathrm{I}+\mathrm{G} 4 \\
\text { 3. } \mathrm{HKY}+\mathrm{F}+\mathrm{G} 4\end{array}$ & $\begin{array}{l}1.6 \\
2.0 \\
3.20\end{array}$ & 601.2735 \\
\hline $\begin{array}{l}\text { Udotea spp. } \\
\text { alignment - } r b c \mathrm{~L}\end{array}$ & $153 \mathrm{bp}$ & $\begin{array}{l}\text { 1. JC+G4 } \\
\text { 2. JC+I+G4 } \\
\text { 3. } \mathrm{HKY}+\mathrm{F}+\mathrm{G} 4\end{array}$ & $\begin{array}{l}1.5 \\
2.0 \\
3.18\end{array}$ & 547.8818 \\
\hline $\begin{array}{l}\text { Caulerpa spp. } \\
\text { alignment - tufA }\end{array}$ & 872 bp & $\begin{array}{l}\text { 1. } \mathrm{F} 81+\mathrm{F}+\mathrm{I}+\mathrm{G} 4 \\
\text { 2. } \mathrm{GTR}+\mathrm{F}+\mathrm{G} 4 \\
\text { 3. } \mathrm{K} 3 \mathrm{P}+\mathrm{I}+\mathrm{G} 4\end{array}$ & $\begin{array}{l}1.6 \\
2.104 \\
3.33\end{array}$ & 3715.158 \\
\hline $\begin{array}{l}\text { Dictyoya spp. and } \\
\text { Dictyopteris sp. } \\
\text { alignment - Cox } 3\end{array}$ & $645 \mathrm{bp}$ & $\begin{array}{l}\text { 1. } \mathrm{GTR}+\mathrm{F}+\mathrm{I}+\mathrm{G} 4 \\
\text { 2. } \mathrm{TPM} 2 \mathrm{u}+\mathrm{F}+\mathrm{I}+\mathrm{G} 4 \\
3 \mathrm{GTR}+\mathrm{F}+\mathrm{I}+\mathrm{G} 4\end{array}$ & $\begin{array}{l}1.55 \\
2.14 \\
3.189\end{array}$ & 7662.413 \\
\hline $\begin{array}{l}\text { Turbinaria ornata } \\
\text { alignment - Cox3 }\end{array}$ & $681 \mathrm{bp}$ & $\begin{array}{l}\text { 1. } \mathrm{HKY}+\mathrm{F}+\mathrm{G} 4 \\
\text { 2. } \mathrm{F} 81+\mathrm{F}+\mathrm{I}+\mathrm{G} 4 \\
\text { 3. } \mathrm{HKY}+\mathrm{F}+\mathrm{G} 4\end{array}$ & $\begin{array}{l}1.16 \\
2.4 \\
3.84\end{array}$ & 1895.4187 \\
\hline $\begin{array}{l}\text { Lobophora spp. } \\
\text { alignment - Cox3 }\end{array}$ & $648 \mathrm{bp}$ & $\begin{array}{l}\text { 1. } \mathrm{GTR}+\mathrm{F}+\mathrm{I}+\mathrm{G} 4 \\
\text { 2. } \mathrm{HKY}+\mathrm{F}+\mathrm{I}+\mathrm{G} 4 \\
\text { 3. } \mathrm{GTR}+\mathrm{F}+\mathrm{I}+\mathrm{G} 4\end{array}$ & $\begin{array}{l}1.61 \\
2.16 \\
3.198\end{array}$ & 12102.0152 \\
\hline
\end{tabular}

Evolutionary models used.

F81= Felsenstein 1981 (Felsenstein 1981)

GTR $=$ General time Reversable (Tavaré 1986)

$\mathrm{HKY}=$ Hasegawa-Kishino-Yano 1985 (Hasegawa et. al. 1985)

$\mathrm{JC}=$ Jukes-Cantor 1969 (Jukes and Cantor 1969)

$\mathrm{K} 2 \mathrm{P}=$ Kimura 2-Parameter (Kimura 1980)

$\mathrm{K} 3 \mathrm{Pu}=\mathrm{Kimura} 3$-Parameter, assuming unequal base frequencies

TIM2 $=$ Transition model

TIM3 = Transition model

TIM3e $=$ Transition model, assuming equal base frequences

$\mathrm{TN}=$ Tamura-Nei 1993 (Tamura and Nei 1993)

$\mathrm{TNe}=$ Tamura-Nei 1993 assuming equal base frequencies (Tamura and Nei 1993)

$\mathrm{TPM} 2 \mathrm{u}=$ Assuming unequal base frequencies

$\mathrm{TPM} 3 \mathrm{u}=$ Assuming unequal base frequencies

$\mathrm{F}=$ Empirical codon frequencies counted from the data

$\mathrm{I}=$ extent of static, unchanging sites in a dataset

G4= gamma distributed rate variation among sites (Yang 1994) 


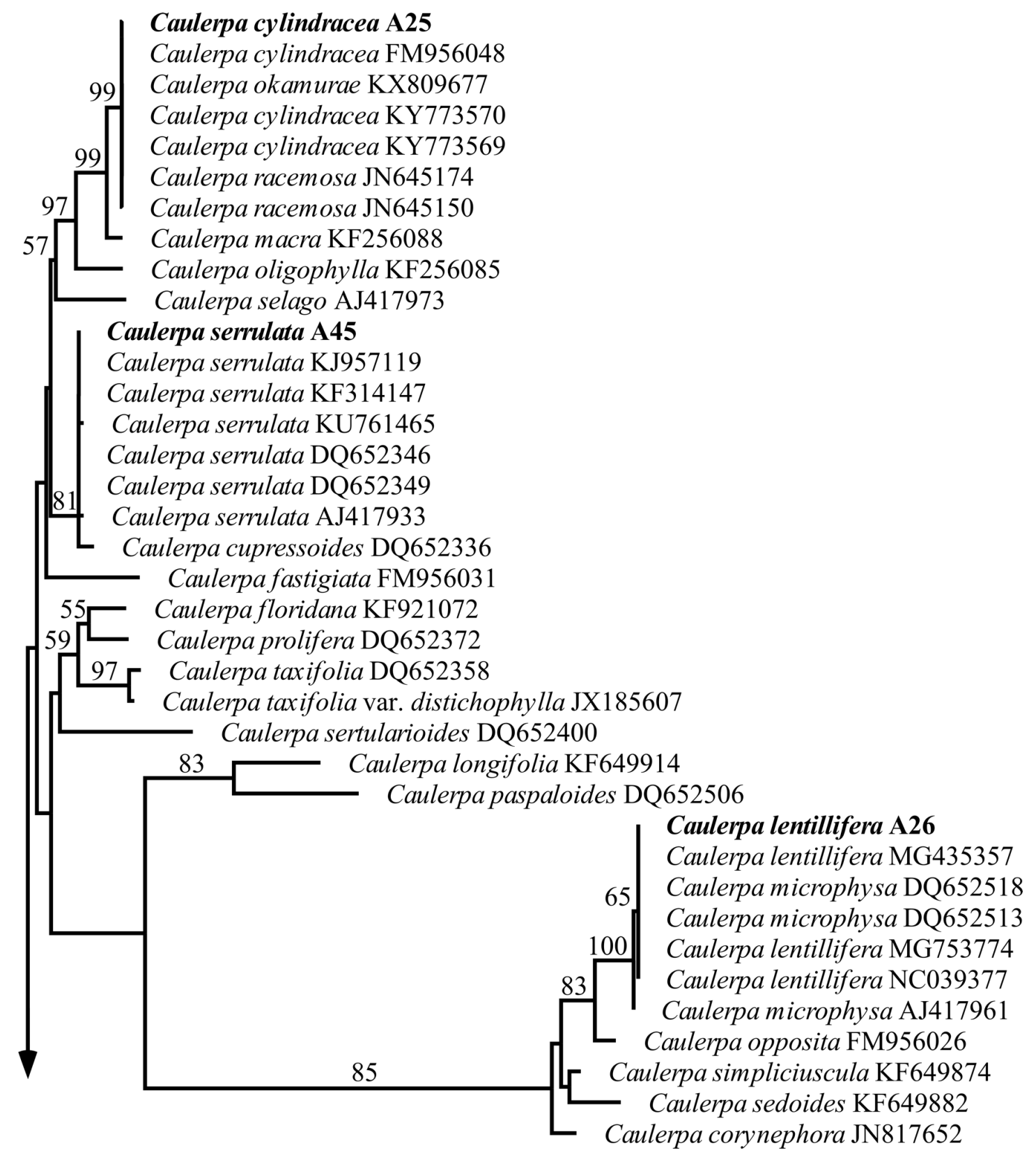




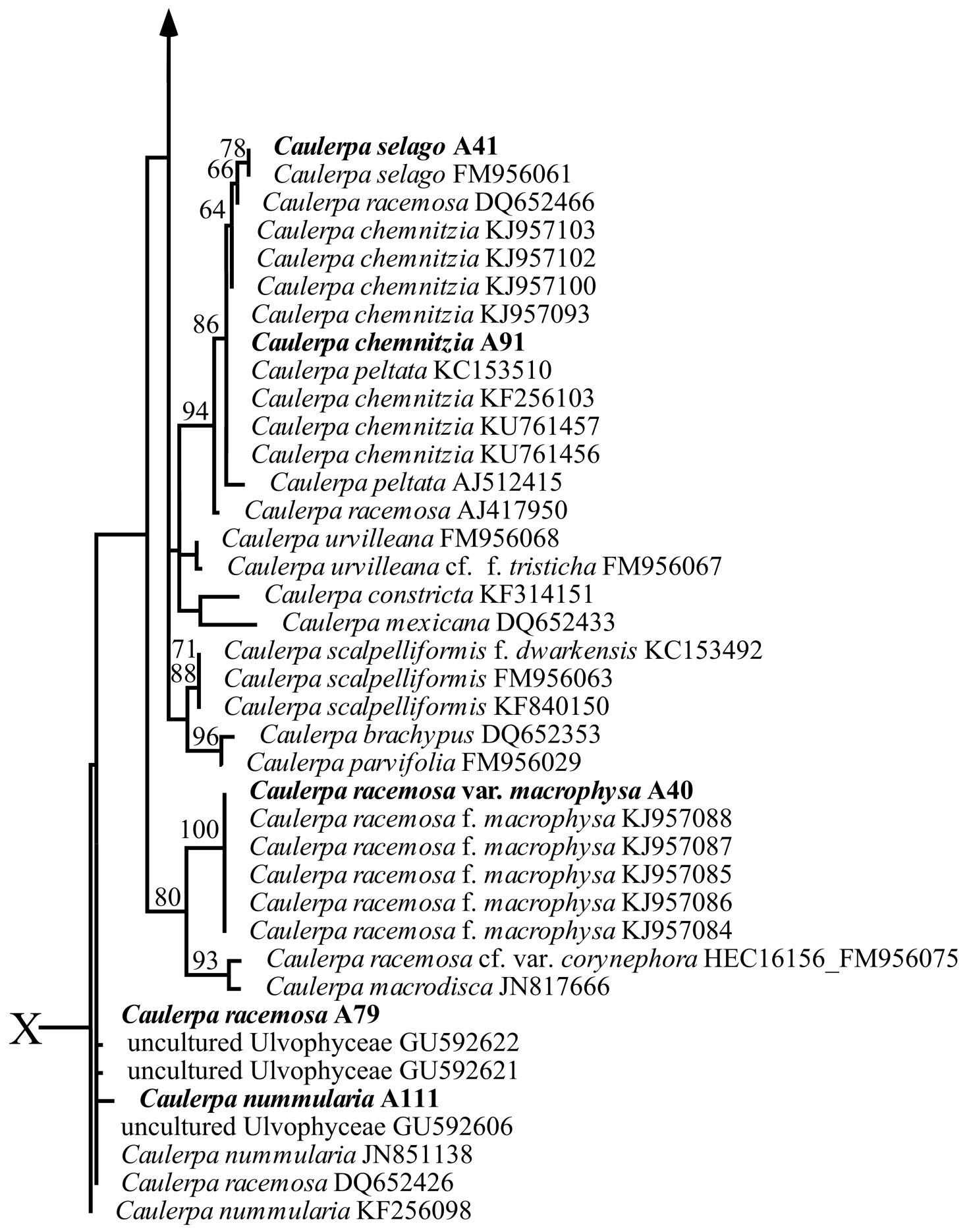

Figure S1. Maximum-likelihood tree of Caulerpa spp. using tufA gene sequences. Samples A25, A26, A40, A41, A45, A79, A91 and A111 shown in bold. Caulerpella ambigua was used as the outgroup and was removed for clarity marked by X. Only bootstrap support values $>50$ displayed. Scale bar $=0.2$ substitutions per site. Arrows show where the tree was cut. 

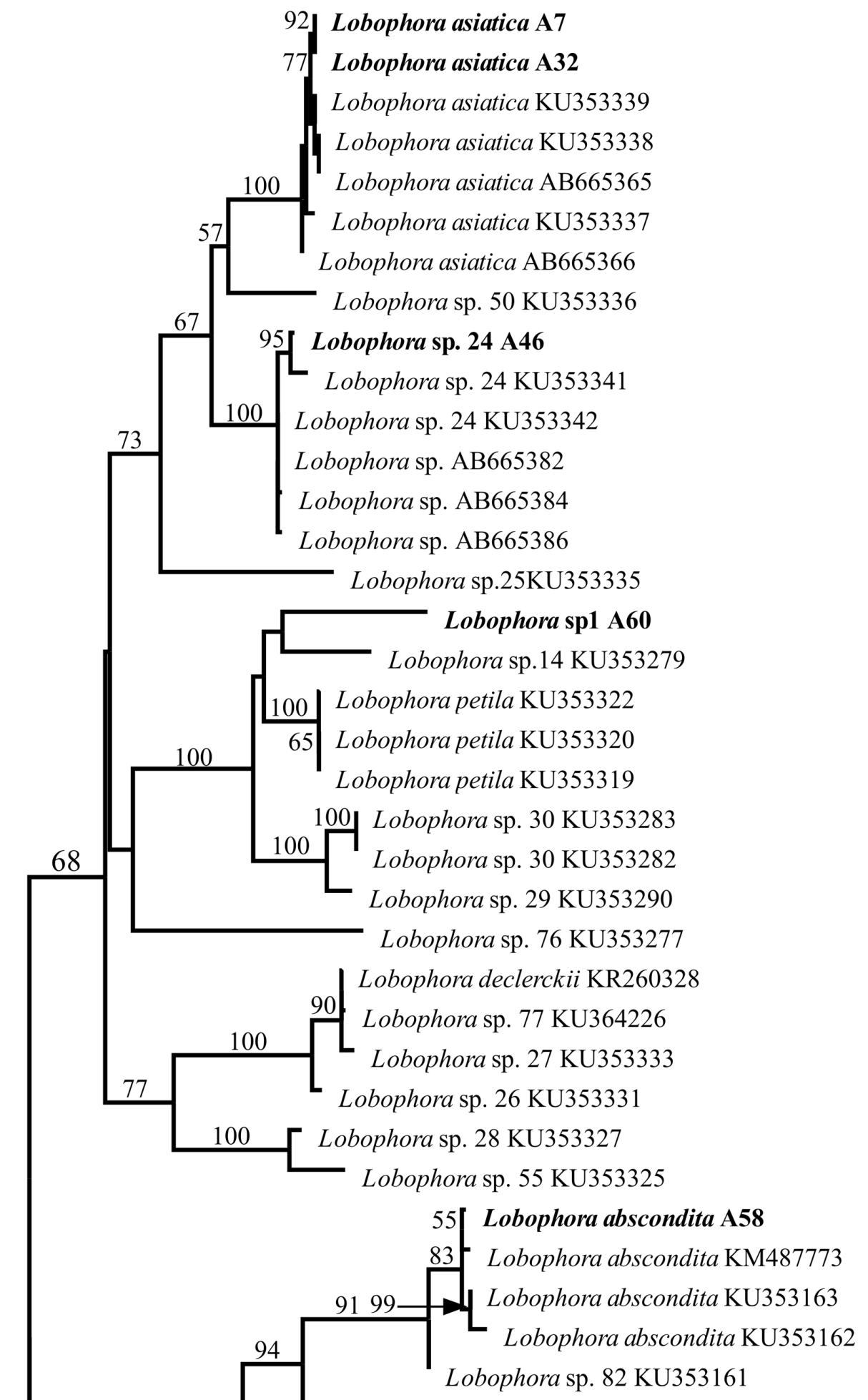

95

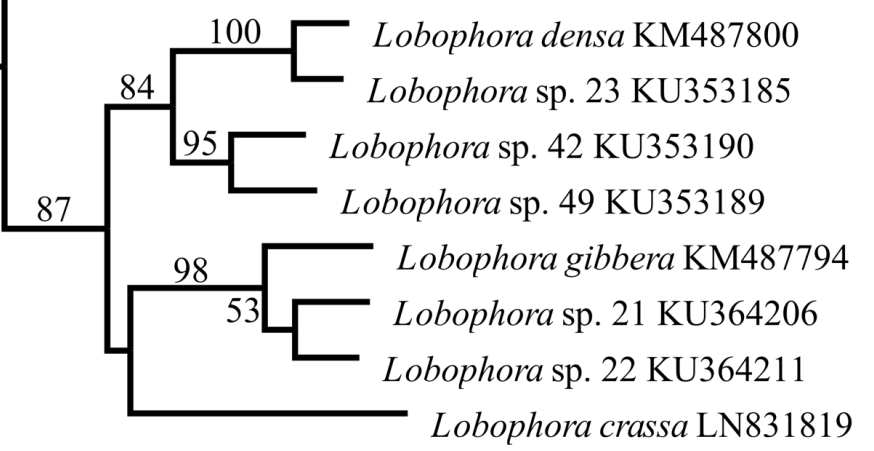




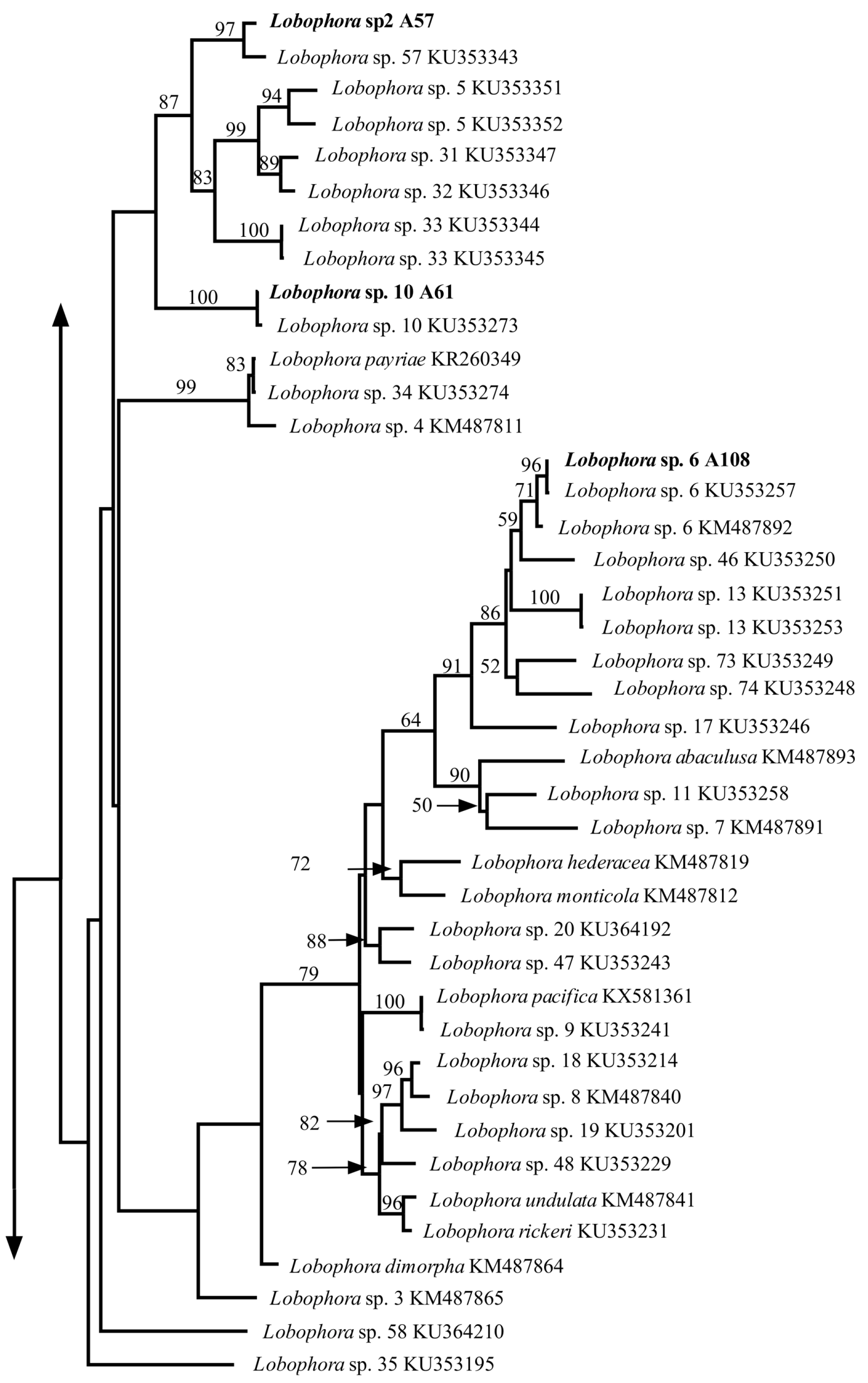




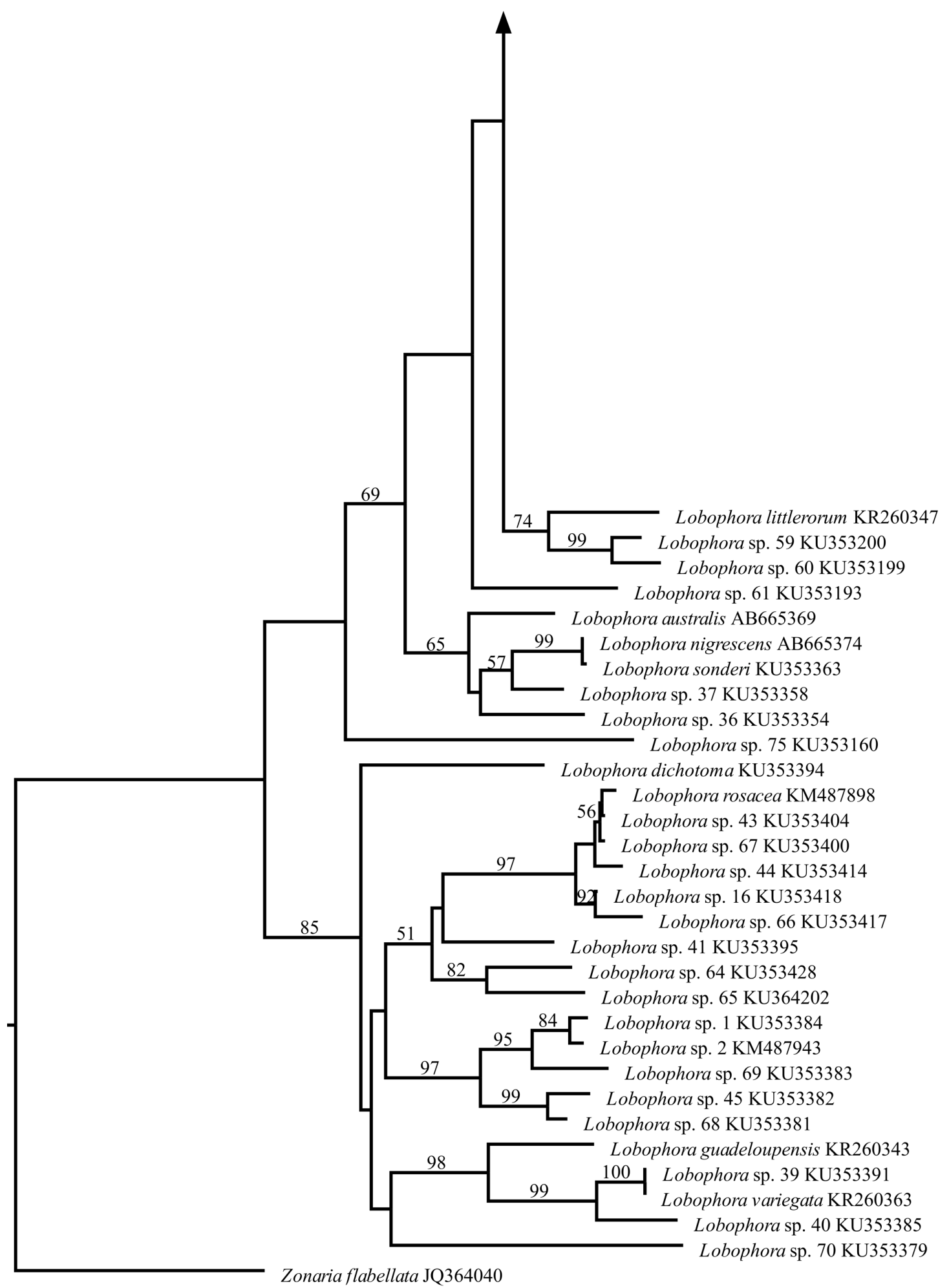

Figure S2. Full maximum-likelihood tree of 116 Lobophora samples based on cox 3 sequences. Samples A7, A32, A46, A57, A58, A60, A61 and A108 are shown in bold. Zonaria flabellata (JQ364040) was used as the outgroup. Scale bar $=0.2$ substitutions per site. Arrows show where the sections of the tree connect. 

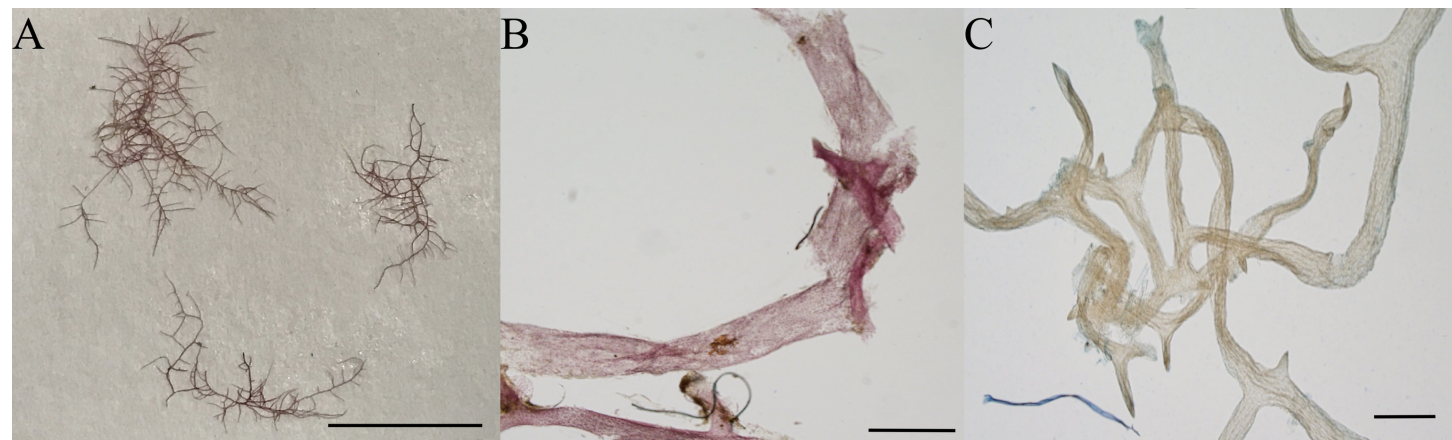

Figure S3. Samples of Hypnea sp. photomicrographs; A $=$ A101, scale bar $=2 \mathrm{~cm}, \mathrm{~B}=$ A94, scale bar $=400 \mu \mathrm{m}, \mathrm{C}=\mathrm{A} 97$, scale bar $=400 \mu \mathrm{m}$,

A
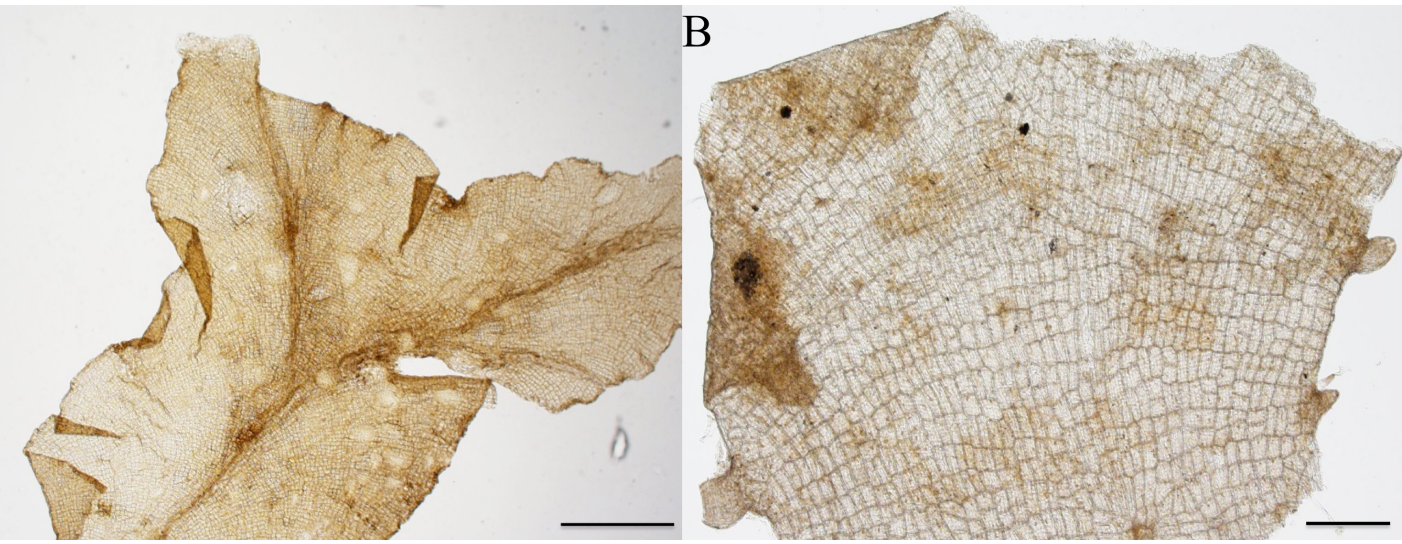

Figure S4. Samples of Dictyopteris sp. and Dictyota sp. photomicrographs; A = A59 unsequenced, scale bar $=1 \mathrm{~mm}, \mathrm{~B}=\mathrm{A} 62$ Dictyota $\mathrm{sp} 1$, scale bar $=1 \mathrm{~mm}$.

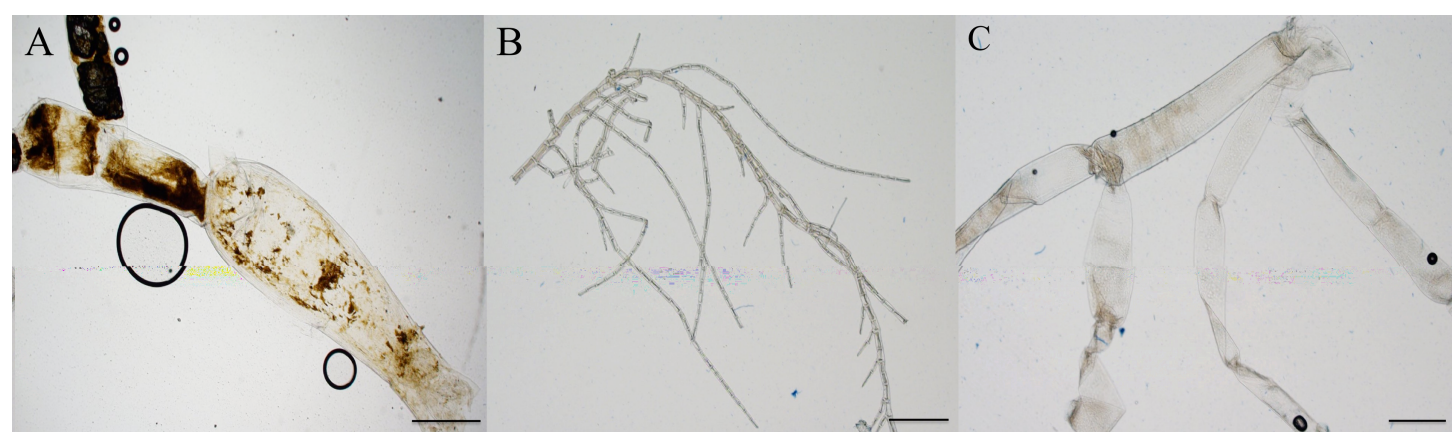

Figure S5. Samples of Cladophora $\mathrm{sp}$. photomicrographs; A = A39, scale bar $=1 \mathrm{~mm}, \mathrm{~B}$ $=\mathrm{A} 115$, scale bar $=400 \mu \mathrm{m}, \mathrm{C}=\mathrm{A} 114$, scale bar $=400 \mu \mathrm{m}$. 